\title{
Size of Specially Protected Forest Sites for Raptors: What Size of These Sites Should be for Protect the Raptor"s Breeding Territories?
}

\section{ПАРАМЕТРЫ ОСОБО ЗАЩИТНЫХ УЧАСТКОВ ЛЕСА ДЛЯ ХИЩНЫХ ПТИЦ - КАКИМИ ОНИ ДОЛЖНЫ БЫТЬ, ЧТОБЫ ОБЕСПЕЧИТЬ СОХРАНЕНИЕ ГНЕЗДОВЫХ УЧАСТКОВ?}

\author{
Karyakin I.V. (Center of Field Studies, N. Novgorod, Russia) \\ Nikolenko E.G. (Sibecocenter LLC, Berdsk, Novosibirsk region, Russia) \\ Bakka S.V. (N. Novgorod Branch of the Russian Bird Conservation Union, Nurgush State \\ Nature Reserve, N. Novgorod, Russia) \\ Карякин И.В. (Центр полевых исследований, Н.Новгород, Россия) \\ Николенко Э.Г. (ООО «Сибэкоцентр», Бердск, Новосибирская область, Россия) \\ Бакка С.В. (Нижегородское отделение Союза охраны птиц России, \\ Государственный природный заповедник «Нургуш», Н.Новгород, Россия)
}

\author{
Контакт: \\ Игорь Карякин \\ Центр полевых \\ исследований \\ 603109, Россия, \\ Нижний НовгороА, \\ ул. Нижегородская, 3-29 \\ тел: +78314333847 \\ ikar_research@mail.ru \\ Эльвира Николенко \\ ООО "Сибэкоцентр" \\ 630090, Россия, \\ Новосибирск, а/я 547 \\ тел.: + 79231501279 \\ elvira_nikolenko@mail.ru \\ Сергей Бакка \\ Нижегородское \\ отАеление СОПР \\ 603001, Россия, \\ Нижний Новгород, \\ ул. Рождественская, $16 \Delta$ \\ тел.: +78314302881 \\ sopr@dront.ru
}

\section{Contact:}

Igor Karyakin Center of Field Studies Nizhegorodskaya str., 3-29, Nizhniy Novgorod, Russia, 603109 tel.: +78314333847 ikar_research@mail.ru

Elvira Nikolenko Sibecocenter LLC P.O. Box 547, Novosibirsk, Russia, 630090 tel.: +79231501279 elvira_nikolenko@mail.ru

Sergey Bakka N.Novgorod Branch of the $R B C U$

Rozhdestvenskaya str., 16d, Nizhniy Novgorod, Russia, 603001 tel.: +78314302881 sopr@dront.ru

\section{Резюме}

В статье приводится анализ влияния различных видов рубок на занятость гнездовых участков разных видов пернатых хишников, собранный преимушественно в борах Аитайского края. Также проанаиизированы реакции хишных птиц на фрактор беспокойства и мля каждого вида определены дистанции вспугивания. САелан обзор межлународного и российского опыта вылеления бусееных зон и особо зашитных участков леса (ОЗУА) вокруг гнёзд хишных птиц. На основании этого предложены размеры особо зашитных участков леса, при которых возможно сохранение гнездовых участков разных видов пернатых хищников.

Киючевые слова: хишные птицы, пернатые хишники, фрактор беспокойства, дистанция вспугивания, бусерная зона, особо зашитные участки леса, ОЗУЛ.

Поступима в редакцию: 25.12.2017 г. Принята к публикации: 31.12 .2017 г.

\section{Abstract}

The article analyzes the influence of various types of felling on the occupation of breeding territories by different species of raptors mainly in the Altai Territory forests. Responses of birds of prey to the disturbance factor are also analyzed. Flight initiation distance is determined for each species. A review of international and Russian experience of buffer zones and specially protected forest areas (SPFA) around nests of raptors was made. On this basis, the article presents the sizes of specially protected forest areas, thus it is possible to preserve breeding territories of different birds of prey species.

Keywords: birds of prey, raptors, human disturbance, alert distance, flight initiation distance, set-back distances, buffer zones, specially protected forest sites, protected areas.

Received: 25/12/2017. Accepted: 31/12/2017.

DOI: $10.19074 / 1814-8654-2017-35-74-175$

\section{Введение}

По оценкам ФАО ООН, плошань леса в России к 2003 г. составляла 8,5 мин. км² (851 мин. га) (Forests..., 2003). По данным Рослесхоза, на начало 2011 г., из 1183,3 млн. га земель лесного фонда 797,1 - покрыто лесами. С 1956 г. значения обшей плошади, запаса и прироста запаса лесов России имеют тенденцию к увеличению, однако средний запас древесины на 1 га и средний возраст мревостоев заметно снижаются (Ежегодный Аоклац..., 2013). Аанные Рослесхоза (рис. 1В) говорят о том, что с 90-х гг. XX столетия по сей день в России ухудшаются условия обитания реАКих виАов хишныХ птиц по причине тотального омоложения лесов!

\section{Introduction}

Currently in several regions of Russia forest communities and birds of prey populations that inhabit them are on the verge of irreversible changes. Increasing exploitation of Russian forests necessitates urgent remedial measures both for sustainable forest management and for the protection of protected by the state forest species, primarily rare and vulnerable.

Russia has a legislative framework for the full protection of habitats of rare and vulnerable species listed the Red Data Books of various levels. In our opinion, the most effective measure to preserve both rare and vulnerable species and the whole biodiversity complex in Russian forests is to create a system of buffer zones in breeding territories of raptors. 
A

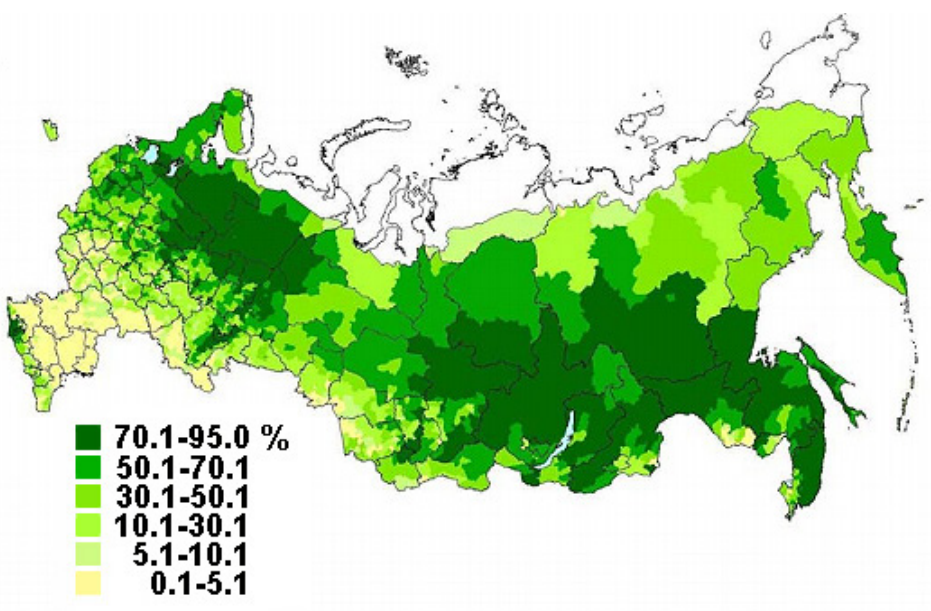

B

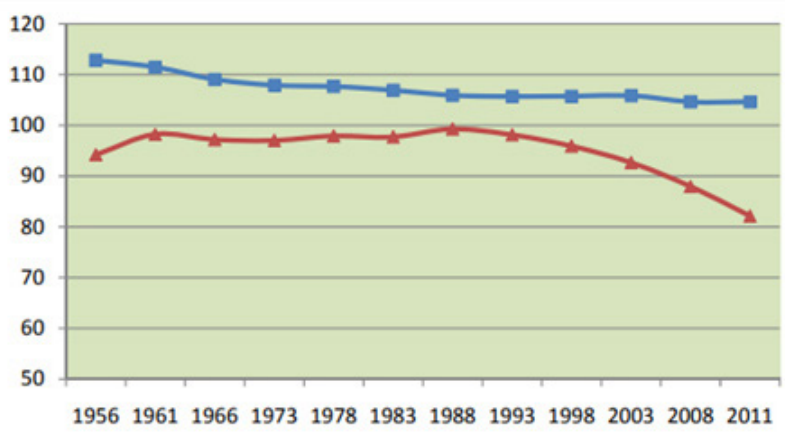

$\rightarrow-$ Средний запас, м3/га (1) - Средний возраст, лет (2)

В ряле регионов страны, особенно в малолесных регионах лесостепной зоны, лесные сообшества и популяции хишных птиц, населяюшие их, находятся на грани необратимых изменений по причине интенсивных рубок. За этой гранью, восстановление как лесов, так и лесных фаунистических комплексов, происходит с откионениями от естественных процессов и может стать необратимым. Уже сейчас во многих регионах наблюдается деградация лесных сообшеств, выражаюшаяся в смене высокопроАуктивных коренных лесов с хозяйственно ценными видами деревьев на производные, в основном мелколиственные леса. Как следствие, из фауны таких дегралировавших лесных сообшеств выпалают крупные хишники, являюшиеся вершинным звеном «экологической пирамиды». В основе причин выпацения хишников из фаунистических комплексов лесных сообществ лежит как регулярное уничтожение их гнёзд в ходе рубок, так и преобразование киючевых гнездопригодных местообитаний. Усиливаюшаяся эксплуатация российских лесов Аиктует необходимость принятия срочных мер как мия устойчивого месопользования, так и мяя охраны лесных виАов, в первую очередь реАких и уязвимых, охраняемых на государственном уровне.
Рис. 1. Аесистость территории России (А) и Аинамика среднего запаса и среднего возраста древостоев (В): 1 - средний запас (м³/га), 2 - средний возраст (лет). По данным Рослесхоза за 2011 г. из: Ежегодный Аокиац..., 2013.

Fig. 1. Forested areas of Russia (A) and trends of average stock and average age of forests (B): 1 average reserve ( $\left.\mathrm{m}^{3} / \mathrm{ha}\right), 2$ - average age (years). According to Rosleskhoz data for 2011 from: Annual report ..., 2013.

Buffer zones around raptor breeding territories, within which the economic activity is restricted or excluded, is the tool that is most often used by state environmental services in many parts of the world (Holmes et al., 1993; Knight, Temple, 1995; Rodgers, Smith, 1997; Richardson, Miller, 1997; U.S. Fish and Wildlife Service, 2007; Pongracz, Horvath, 2010).

The practice of specially protected forest areas (SPFA) allocation, established by the Russian legislation, could contribute to creating a buffer system in breeding territories of raptors in Russia.

To avoid misreading between forestry and environmental legislation, it is necessary to consolidate the parameters of SPFA allocation around nests of rare raptors species in forestry legislation. But what are the SPFA parameters that are applicable to different raptor species listed in the Red Data Book of the Russian Federation and regional Red Data Books? This article will endeavor to answer this question.

\section{Methodical approaches}

All the recommendations for selecting the parameters of specially protected forest areas around the nests are derived from two approaches in assessing the responses of birds of prey to disturbance:

1) analysis of behavioral bird responses to direct human disturbance (Grubb, King, 1991; Anthony et al., 1995, Rodgers, Smith, 1995; Fernández-Juricic et al., 2001; Rodgers, Schwikert, 2002; Fernández-Juricic, Schroeder, 2003; Williams et al., 2013),

2) analysis of bird responses to habitat changes during economic activity (Rudnicky, Hunter, 1993; Gram et al., 2003; Yahner, 2003; Alterman et al., 2005; Wallendorf et al., 2007; Morris et al., 2013; Williams et al., 2013; Porneluzi et al., 2014).

When analyzing behavioral bird responses to direct human disturbance, one and/or two indicators are used (Livezey et al., 2016):

a) alert distance, hereafter AD - the distance between the source of disturbance 
Законодательную основу мяя сохранения местообитаний реАких и уязвимых вилов в России создают федеральные законы "О животном мире" (Ст. 24. Охрана редких и находяшихся под угрозой исчезновения объектов животного мира) (Федеральный закон..., 1995), "Об охране окружаюшей среды" (Ст. 60. Охрана редких и находящихся под угрозой исчезновения растений, животных и Аругих организ мов) (Федеральный закон..., 2002), постановление Правительства РФ «О Красной книге Российской Федерации" (Постановмение..., 1996), Приказ Госкомэкологии РФ «Об утверждении Порядка ведения Красной книги Российской Федерации" (Приказ..., 1997), КоАП (ст. 8.35. Уничтожение редких и находяшихся под угрозой исчезновения видов животных или растений) и лесное законодательство (Кодекс..., 2001). Также, правила заготовки древесины (Приказ..., 2007) требуют сохранения местообитаний видов, занесённых в Красные книги, и мругих важных мля подмержания биоразнообразия участков леса непосредственно при лесозаготовках.

Таким образом, в России имеется законодательная основа мия полноценной охраны мест обитания редких и уязвимых видов, внесённых в Красные книги различного уровня.

Наиболее хейственной мерой, на наш взглял, Аля сохранения как редких и уязвимых видов, так и мия всего комплекса биоразнообразия в российских лесах может стать создание системы охраняемых зон в местах гнездования хишных птиц. Хищные птицы имеют обширные гнездовые участки, которые приурочены к кАючевым Аля лесных сообшеств биотопам. Как прави^о, именно на гнездовых участках хишных птиц сосредоточено максимальное разнообразие Аругих видов животных и растений, а также наблюдается повышенная концентрация редких и охраняемых видов из Аругих групп организмов. В связи с этим хишные птицы рассматриваются в качестве

Гнездо большого подорлика (Aquila clanga), мар кированное с целью создания вокруг него ОЗУА (Корниловский заказник, Прослаухинская КОТР, Аитайский край). Фото И. Карякина.

Nest of the Greater Spotted Eagle (Aquila clanga) marked for a purpose of creating specially protected forest area around it (Kornilovsky Nature Reserve, Proslaukhinskaya IBA, Altai Kray).

Photos by I. Karyakin. (usually a single walker) and the bird at the point where the bird changes its behavior in response to an approaching source of disturbance (Fernández-Juricic, Schroeder, 2003),

b) flight initiation distance, hereafter FID - the distance between the source of disturbance and the bird at the point where the bird begins to move away from the approaching source of disturbance (fig. 2) (Blumstein, 2006; Møller, 2010; Glover et al., 2011; Gendall et al., 2015).

Despite many disadvantages of this approach, widely discussed in foreign literature (Gutzwiller, Marcum, 1997; Rodgers, Smith 1997; Stalmaster, Kaiser 1997; Gill et al., 2001; Beale, Monaghan, 2004), it is

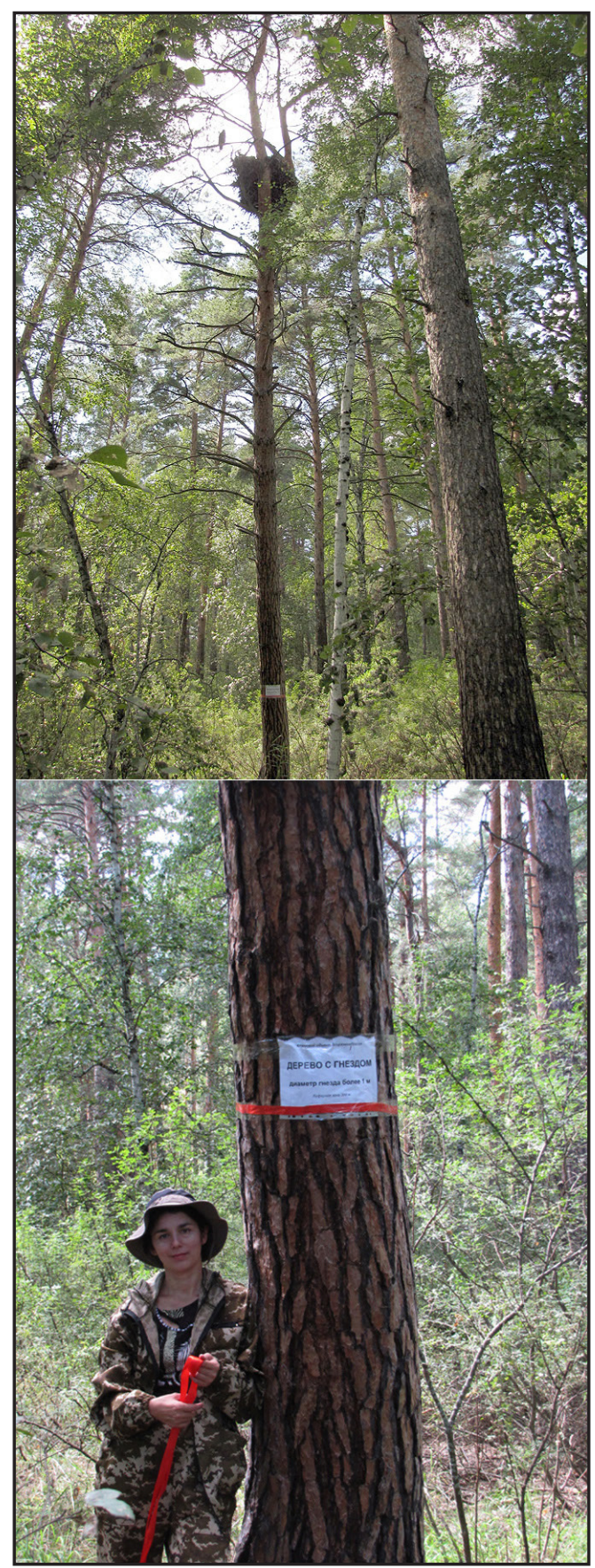


"зонтичных" мия сохранения всего биоразнообразия (Newton, 1979; Roberge, Angelstam, 2004; Sergio et al., 2006).

Создание охраняемых или "бусерных" (в зарубежной терминологии) зон вокруг потенциально чувствительных к деятельности человека участков дикой природы (например, гнездовых участков пернатых хишников), в пределах которых ограничивается или искиючается хозяйственная деятельность, - наиболее часто используемый государственными природоохранными службами инструмент во многих странах мира (Holmes et al., 1993; Knight, Temple, 1995; Rodgers, Smith, 1997; Richardson, Miller, 1997; U.S. Fish and Wildlife Service, 2007; Pongracz, Horvath, 2010).

Созданию системы охраняемых зон в местах гнездования хишных птиц в России может способствовать практика вылеления особо зашитных участков леса (ОЗУЛ), закреплённая российским законодательством.

Согласно Приложению 4 к лесоустроительной инструкции, утвержАённой приказом Рослесхоза от 12.12.2011 г. № 516, в качестве ОЗУА вылеляются участки лесов, являюшиеся местами обитания редких и находяшихся поА угрозой исчезновения Аиких животных, занесённых в МежАународную Красную книгу, Красную книгу Российской Федерации (КК РФ) и Красные книги субъектов Российской Федерации (Приказ..., 2011).

К сожалению, в Российском лесном законодательстве полностью отсутствуют параметры вылеления ОЗУА в местах обитания редких и находяшихся поА угрозой исчезновения Аиких животных (они прописаны кишь мия токов куриных птиц) эта зацача отдана на откуп специаиистов. Как следствие, в каждом регионе имеется Свой поАХОА, иногАа противоречаший Российскому природоохранному законодательству. В частности, Распоряжением Министерства природных ресурсов и лесопромышленного комплекса Архангельской области от 20 Аекабря 2012 г. № 826p утверждены Методические рекомендации по сохранению биоразнообразия при заготовке Аревесины в Архангельской области, в которых при обнаружении крупных гнёзд (Аиаметром около 1 м и более) необходимо установить бусерную зону рахиусом не менее 30 м вокруг $ы е-$ рева с гнездом. Точное выполнение лесопользователями Аанной рекомендации (т.е. рубка леса в 30 м от гнезда) ведёт к уничтожению местообитания вида, зане- most common in foreign countries where with a large number of observers it is possible to collect quite quickly and easily the information on bird responses to observer (for example, by questionnaire survey Ruddock, Whitfield, 2007; Whitfield et al., 2008).

The second approach (analysis of bird responses to habitat changes) most adequately assesses raptor response to habitat disturbance in breeding territories, but it is more labor-intensive, requires long-term observations of nests in commercial forests, and in some cases breach of legislation by forest management companies, which is avoided in many civilized countries. In Russia, the very few companies do environmentally responsible forest management and do not break the law, therefore in some regions there are perfect "demonstration trails" for identifying the impact of felling on the occupation of breeding territories of species listed in the IUCN Red List and the Red Data Book of Russia. The Altai Kray is a good example, where the scale of rare species nests destruction is much greater than in other regions of Russia: Gribkov, 2014; Nikolenko et al., 2012; 2013; Nikolenko, 2014; Karyakin, 2015; Karyakin et al., 2015a; Karyakin, Nikolenko, 2015a; 2016; Zinevich et al., 2016.

Some researchers, while developing the parameters of protected areas around nests of birds of prey, also follow the choice of habitats by birds, based on distances to disturbed natural communities and places of constant or irregular presence of people (Viter, 2014). We will refer to this information, but we will not use it in this article, since this is a separate line requiring extension study.

\section{Methods}

Information for 2398 nests in 1234 breeding territories of raptors about forest structural disturbance was collected during visual inspection within monitoring in a number of regions (Perm Region, Republic of Bashkortostan) from 1991 to 1999 , and in the main territory, which provided the mass materials for work (forests of the Altai Kray), - from 2003 to 2016. Information for 405 nests in 373 breeding territories of birds of prey about forest structural disturbance was collected from satellite images for the period preceding the last examination of nests. A total of 2803 nests in 1607 breeding territories were visited within the monitoring program; 481 nests (17\% from the visited) were abandoned as a result of forest structural disturbance near them. 
сённого в КК РФ и попадает под Аействие ст. 8.35 КоАП, так как гнёзда диаметром 1 м и более могут принамежать только видам из КК РФ и Красной книги Архангельской области, а рубка в 30 м от гнезда равноценна уничтожению самого гнезда, так как гнездо после рубки на такой Аистанции от него, однозначно будет брошено птицами. К тому же данная рекомендация идёт вразрез с Красной книгой Архангельской области, являюшейся базовым Аокументом по государственной охране редких видов региона, гле мия таких видов, как беркут (Aquila chrysaetos) и орлан-белохвост (Haliaeetus albicilla), размер гнёзд которых 1 м и более, указаны следуюшие меры охраны: "необходима строгая охрана гнезАовых участков, организация вокруг них охранной зоны рахиусом не менее 1 км, гАе следует искиючить все виды лесопользования, кроме осушествляемых в научноисследовательских целях" (Рыкова, 2008).

Чтобы не было разночтений межАу лесным и природоохранным законодательством, необходимо закрепление параметров вылеления ОЗУА вокруг гнёзА реАких видов хищных птиц в лесном законодательстве, как минимум в Аесоустроительной инструкции. Но какими должны быть параметры ОЗУЛ, применимо к разным видам хишных птиц из Красной книги РФ и региональных Красных книг? На этот вопрос мы и попытались ответить в Аанной статье.

В зацачи работы входит определение оптимальных параметров ОЗУА мия сохранения хищных птиц на основе поведенческих реакций и ответа птиц на нарушения на их гнездовых участках, как на основе международного опыта, так и на основе опыта авторов, полученного в ряде регионов. Основной практический материал мя исследований был собран в Алтайском крае, гАе холАингом "Алтайлес", выстроившим в регионе "коррупционную вертикаиь", ежегодно безнаказанно в ходе рубок леса уничтожаются десятки гнёзд пернатых хишников, в том числе редких, внесённых в Красные книги России и Алтайского края. Реакция пернатых хишников на рубки в пределах гнездовых участков на разной удалённости от гнёзд позволила вылемить те Аистанции и те нарушения, которые критичны дяя разных видов.

\section{Методические подходы}

Имеется Ава подхода в оценке реакции хишных птиц на беспокойство, которые лежат в основе всех рекомендаций по выбору параметров зон особой охраны вокруг гнёзА:
To assess the impact of disturbances on nest occupancy, buffers with a radius of 930 $\mathrm{m}$ were built around the nests; they were divided into zones 1-30, 31-90, 91-210, 211-450 and 451-930 m, respectively (fig. 3). Disturbances that occurred outside the buffer were not monitored and the status of nests with respect to these disturbances was not analyzed.

For all cases of disturbances, the distance from the nest to the disturbance zone and the type of disturbance were registered. If possible, the type of felling was recorded for felling. For distances from an abandoned nest to the disturbance zone, DD abbreviation (distance to disturbance) is authorized. Dangerous zone (DZ) was calculated by the maximum distance from the nest to the edge of disturbance, whereon the birds left the nest during or after the disturbances occurred. For distances from the inhabited nest to the disturbance zone, if the nest is in a dangerous zone, DN abbreviation (dangerous neighborhood) is authorized.

Per totality of field observations of forest species of raptors in 6315 breeding territories for which behavioral responses were recorded, distances tables with responses of birds disturbance up to the flight initiation (FID) were made - 8219 observations. Where 1714 observations of single birds, predominantly males, were recorded in breeding territories during incubation, 1929 in the period of fledging, and 1996 and 1996 observations of adult birds, predominantly females, on nests during incubation and fledging, respectively. This material became additional as a validation of species-specific parameters for the allocation of buffer zones.

The material was occasionally collected from 1991 to 2002 and more or less regularly from 2003 to 2016 (fig. 5).

For the purposes of the article, foreign and Russian literature was also analyzed. It provides data on the parameters of protective zones around the nests of raptors. The approved regulations and scientific papers were selected and analyzed separately.

The results were processed in MS Excel 2003 and Statistica 10. For comparison of distances the t-test was used for independent variables.

\section{Research results and their discussion}

FIDs according to the results of the authors' research are given in table 1 .

FID analysis shows the highest tolerance to the disturbance factor in adult nesting birds (FID is minimal) than in single birds in 
1) анализ поведенческих реакций птиц на прямое беспокойство человеком (Grubb, King, 1991; Anthony et al., 1995, Rodgers, Smith, 1995; Fernández-Juricic et al., 2001; Rodgers, Schwikert, 2002; Fernández-Juricic, Schroeder, 2003; Williams et al., 2013);

2) анамиз ответа птиц на изменение местообитаний в ходе хозяйственной деятельности (Rudnicky, Hunter, 1993; Gram et al., 2003; Yahner, 2003; Alterman et al., 2005; Wallendorf et al., 2007; Morris et al., 2013; Williams et al., 2013; Porneluzi et al., 2014).

При анализе поведенческих реакций птиц на прямое беспокойство человеком используются регистрации одного и/или Авух показателей (Livezey et al., 2016):

а) Аистанция, на которой наблюдается беспокойство птицы (alert distance, далее AD) - расстояние межАу источником беспокойства (обычно одиноким пешеходом) и птицей в точке, гАе она меняет своё поведение в ответ на приближаюшийся источник беспокойства (Fernández-Juricic, Schroeder, 2003);

б) Аистанция вспугивания птицы (flight initiation distance, малее FID) - расстояние межАу источником беспокойства и птицей в точке, гАе птица начинает удаияется от приближаюшегося источника беспокойства (рис. 2) (Blumstein, 2006; Møller, 2010; Glover et al., 2011; Gendall et al., 2015).

Несмотря на многие недостатки такого подхода, широко обсужлаемые в зарубежной митературе (Gutzwiller, Marcum, 1997; Rodgers, Smith 1997; Stalmaster, Kaiser 1997; Gill et al., 2001; Beale, Monaghan, 2004; Møller et al., 2014), он наиболее распространён в зарубежных странах, гАе при огромном количестве наблюдателей можно Аовольно быстро и легко (например, методами анкетного опроса, см. Ruddock, Whitfield, 2007; Whitfield et al., 2008) собрать инсрормацию по реакциям птиц на человека. При переложении ханных результатов исследований в плоскость оценки влияния изменений в местооби- territories at some distance from the nests both during the incubation period ( $t=23.54$; $c c=3705 ; p<0.05)$, and during the period of fledging ( $t=13.00 ; c c=4335 ; p<0.05)$. This is definitely related to the unwillingness of birds to uncover the nest. In particular, a number of covered species sit on nests to the last, putting up with the walkers under the nest. At the same time, even in Ural Owls (Strix uralensis), sitting close in the nests, AD is observed at distances significantly exceeding FID. Unfortunately, we did not register ADs in most cases because of the certain difficulties of their interpretation. For a number of species, AD and FID parameters were obtained in Scotland (Ruddock, Whitfield, 2007) and we may focus on them (see table 2), when comparing with our data.

In our sample there is also an increase of FID for birds in nests during the fledging, in contrast to the incubation period $(t=-20.12$; $c c=4399 ; p<0.05)$. Interestingly that during the second half of summer (in the fledging period), FID for adult birds increases in territories away from the nests $(t=-6.60$; $c c=3641 ; p<0.0005)$. The majority of adult birds of the same species, and moreover, the same birds, found in June and July at roost site away from the nests, flew away seeing the observers at longer distances than in April-May.

The maximum FIDs are specific to such large species, as the true eagles (Aquila sp.) and the White-Tailed Eagle (Haliaeetus albicilla), among which the Golden Eagle (Aquila chrysaetos) has the lead $267.50 \pm 125.48 \mathrm{~m}$; lim 70-600 m. The range of FID in large raptors outside the nests is fairly close and lies in the range from 150 to $300 \mathrm{~m}$ (table 1 ).

FID for birds in the nests varies depending on the strategy for selecting the nesting territories. The Imperial Eagle is shier. Most of its nests are on open spaces $(224.30 \pm 125.69 \mathrm{~m}$; lim 10-550 m), while flight initiation distances of the Golden Eagle are reduced due to the fact that the nests are located inside the forests.

Distances from the nests to the edge of the disturbance zones, whereon the nests are left by the raptors (DD), are given in table 3. The zone of $30 \mathrm{~m}$ from the nest is critical for all species of raptors: $92.3 \%$ of abandoned nests in this zone are near the clear felling, $100 \%$ - near selection felling and $86.7 \%$ - at the edge of the fire line or linear facility, for the construction of which the land was cut over (route, power line, 
Гнездо фрилина (Bubo bubo) с погибшей киацкой, оставленное птицами в результате беспокойства при отводе леса в рубку (Аитайский край). Фото И. Карякина.

Nest of the Eagle Owl (Bubo bubo) with dead clutch abandoned by birds as a result of anxiety caused by loggers (Altai Kray). Photo by I. Karyakin. таниях на занятость гнездовых участков может случиться несовпадение ответной реакции хишных птиц на оба этих фрактора (беспокойство и нарушение среды). В качестве примера можно привести ряА видов, демонстрируюших толерантность к беспокойству, но при этом уязвимость к нарушениям среды обитания в пределах гнездового участка. Так, например, ястреб-тетеревятник (Accipiter gentilis) в ряле регионов Европейской части России, демонстрирует беспокойство только при мительном нахожлении ^юдей на участке в непосредственной близости от гнезда. При кратковременных осмотрах гнёзА с земли на дистанции от нескольких метров $\Delta$ оескольких десятков метров от гнезАа, самки часто плотно сидят на гнёздах, а самцы не проявляют беспокойства, находясь поблизости. Аналогичным образом ведут себя чёрные коршуны (Milvus migrans) в Южной Сибири и мииннохвостые неясыти (Strix uralensis), допуская даже миительное беспокойство под гнёздами ( $\Delta$ о 6 и более часов), не слетая с киалок или выводков, если ^юди не поднимаются на гнездовое дерево или не ударяют по нему, стараясь спугнуть птицу с гнезАа. В то же время мия всех этих виАов критическим является нарушение структуры леса вокруг гнезда на Аистанции в несколько десятков метров и птицы бросают гнёзда даже при проведении близ них выборочных рубок.

Второй подход (анализ ответа птиц на изменение местообитаний) наиболее амекватно позволяет оценить реакцию хищников на нарушение среды обитания на гнездовых участках, однако он более тру-

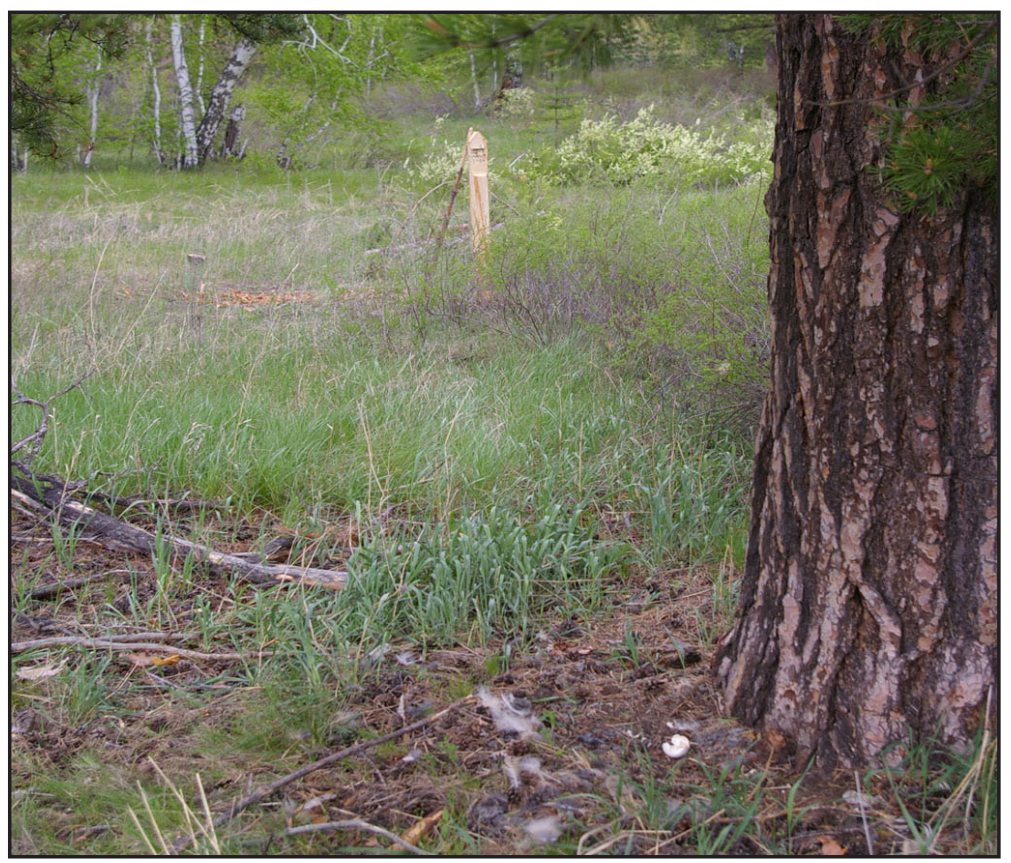

gas pipeline, irrigation or drainage channel). For the zone of 31-90 $\mathrm{m}$ from the edge of the disturbed forest community, there is a smaller number of abandoned nests - from 45-50\% to $81.45 \%$, and for the zone of 91-210 m - very small percentage: 0.18 $7.12 \%$. Moreover, the basic statistical data on responses is provided by the common small and medium sized species, such as the Sparrow Hawk (Accipiter nisus), the Black Kite (Milvus migrans), the Common Buzzard (Buteo buteo), the Goshawk (Accipiter gentilis), the Ural Owl. If we examine separately such large species as the Osprey (Pandion haliaetus), White-Tailed Eagle, Golden Eagle, Imperial Eagle (Aquila heliaca), Greater Spotted Eagle (Aquila clanga) and Eagle Owl (Bubo bubo), then the zone of critical disturbances for them is extended to $100 \mathrm{~m}$ and more: from 92 to $100 \%$ of abandoned nests in the zone up to $90 \mathrm{~m}$, from 1 to $86 \%$ of abandoned nests in the zone from 91 to $210 \mathrm{~m}$ from the nest. Up to $6 \%$ of abandoned nests are at the distance up to $450 \mathrm{~m}$ from the edge of the disturbance zone, and up to $1.6 \%$ are at the distance over $450 \mathrm{~m}$. At a distance of more than $450 \mathrm{~m}$ from the edge of selective felling, 3 nests of the Greater Spotted Eagle and 3 nests of Eagle Owl in the Altai pine forests were abandoned.

Out of 555 observations of raptor nests in the forest structural disturbance zones (DZ) only $12.43 \%$ were occupied by birds. Most of the nests $(87.57 \%)$ were left by birds either in the same year when the disturbance occurred, or the next year if the disturbance occurred in the late stages of fledging or after the breeding (table 4). The distances where the inhabited nests (DN) were observed in the dangerous zone show the threshold of response of the species to disturbances in its territories (fig. 6). We can move forward from them, as minimum required, to preserve one or another species.

FID and DD ratio shows that for making the buffer zones it is more correct to compare the average FID values with the maximum distance from the edge of the disturbance zone to the bird nest on which this nest is abandoned (DD-M), since the average DD values show only the actual situation with the abandoned nests in one disturbance zone, not the threshold response of birds to these disturbances (see fig. 7, table 5).

Local disturbances do not always lead to non-returnable leave of species from the territory on which they occurred. Many years monitoring of the breeding territories 
Аоёмок, требует многолетних наблюдений за гнёздами в эксплуатационных ^есах, а в ряде случаев - и нарушения законодательства со стороны лесохозяйственных компаний, что, как правило, отсутствует во многих цивилизованных странах, гАе многие компании стремятся сохранить свой имидж как экологически ответственной организации. В России же ситуация противоположна: только единичные компании ведут экологически ответственное лесопользование и не нарушают законодательство, поэтому в ряде регионов имеются отличные "экспериментаиьные полигоны" по выявлению влияния рубок на занятость гнездовых участков, в т.ч. видов, внесённых в Красный список МСОП и Красную книгу России (хорошим примером является А^тайский край, в котором масштабы уничтожения гнёзд редких видов на порялки выше, чем в Аругих регионах России: Грибков, 2014; Николенко и Ар., 2012; 2013; Николенко, 2014; Карякин, 2015; Карякин и Ар., 2015а; Карякин, Николенко, 2015а; 2016; Зиневич и Ар., 2016).

Некоторые исследователи, при разработке параметров охраняемых зон вокруг гнёзд хишных птиц, ориентируются также на выбор птицами местообитаний, исходя из дистанций $\Delta$ о нарушенных природных сообшеств и мест постоянного ихи нерегулярного присутствия ^юдей (см., например, Витер, 2014). Мы будем ссылаться на эти сведения, но использовать в данной работе не будем, так как это отдельное направление, требуюшее дополнительных исследований.

\section{Методика}

Обработка полевого материала, собранного авторами, осушествлялась в среде ГИС ArcView 3x, куда импортировались Аанные мониторинга гнездовых участков хищных птиц из раздела "Пернатые хишники Мира" веб-ГИС "Фаунистика" (Пернатые..., 2017; RRRCN, 2017) и базы Аанных Центра полевых исследований, собранные в рамках программы мониторинга редких видов Российской сети изучения и охраны пернатых хишников ${ }^{145}$.

Аля 2398 гнёз на 1234 гнездовых участках хишных птиц инсормация о нарушениях структуры леса собрана в ходе визуамьного осмотра в рамках мониторинга, ведушегося в ряле регионов (Пермская область, Республика Башкирия) с 1991 по 1999 гг., а на основной территории, дав- where nests were left by raptors after the nearby forest felling, showed that the birds return in some territories.

We did not register any return of the Osprey, the Golden Eagle, the Booted Eagle (Hieraaetus pennatus) and the Saker Falcon to their former territories, even if the nests were preserved. For other species, the returns were from 5 to $30 \%$.

The leader in returning to the territories affected by felling is the White-Tailed Eagle - the birds returned to $30.4 \%$ of the abandoned territories (7 out of 23). Almost all returns ( 5 of 7 ) were to the nests that were left by birds after felling in 105-205 $\mathrm{m}$ from the nests.

In the case of Greater Spotted Eagles from the sample of 52 abandoned nests after felling, only 3 (5.77\%) birds returned for the $7^{\text {th }}, 9^{\text {th }}$ and $10^{\text {th }}$ year after the disturbance.

In the case of the Eagle Owl, 16 returns were recorded with 55 cases of leaving the nesting grounds. Only one pair returned to its ground the year after its clutch was destroyed because of felling. The rest territories were again occupied by Eagle Owls in 3-6 years all of them were restored within the distances from 100 to $500 \mathrm{~m}$ from the former nests to the edge of the forest stands after felling.

As for the ordinary raptors like Black Kite (97 abandoned nests) and Common Buzzard (39 abandoned nests), $27.84 \%$ and $20.51 \%$ of returns to their territories after selective felling were recorded.

Regardless of the type of disturbances per totality of observations, species-specific material was obtained on the distances from nests to forest structural disturbance zones, which, along with FID for different species in different periods of breeding, makes it possible to develop buffer zones for the protection of raptors.

\section{Validation of buffer zone sizes around the nests of raptor}

Foreign studies show that during the incubation period FID $=0.44^{*} \mathrm{AD}$, but is higher during the fledging, but at both stages of the breeding cycle FID is about half of AD, and $A D$ is recommended as an argument for validating the species-specific sizes of the buffer zones (Whitfield et al., 2008).

The results of our study show that the maximum FID indicators (for birds outside the nests during fledging) for most species are in the range of $30-90 \%$ of the maximum DD values (table 5). Exceptions are 
Рис. 3. Буферные зоны вокруг гнёзд Аһя анаииза в^ияния нарушений.

Fig. 3. Buffer zones around the nests for analyze the effect of disturbances. шей наиболее массовый материал мия работы (боры Алтайского края), - с 2003 по 2016 гг. Амя 405 гнёзд на 373 гнездовых участках хишных птиц информация о нарушениях структуры леса получена по космоснимкам за период, предшествуюший последней проверке гнёзд. Всего в рамках программы мониторинга посешено 2803 гнезда на 1607 гнездовых участках; 481 гнездо (17 \% от числа посешавшихся) было брошено птицами в результате произошеАших вблизи них нарушений структуры меса.

Аия оценки влияния нарушений на занятость гнёзд, вокруг последних были построены бусреры, рахиусом 930 м, которые были разбиты на зоны 1-30, 31-90, 91-210, 211450 и 451-930 м соответственно (рис. 3). Грацации бусрерной зоны были рассчитаны в ArcView на основании контрольной выборки гнёзд. Нарушения, происходившие за пределами буфера 930 м, не отслежива-

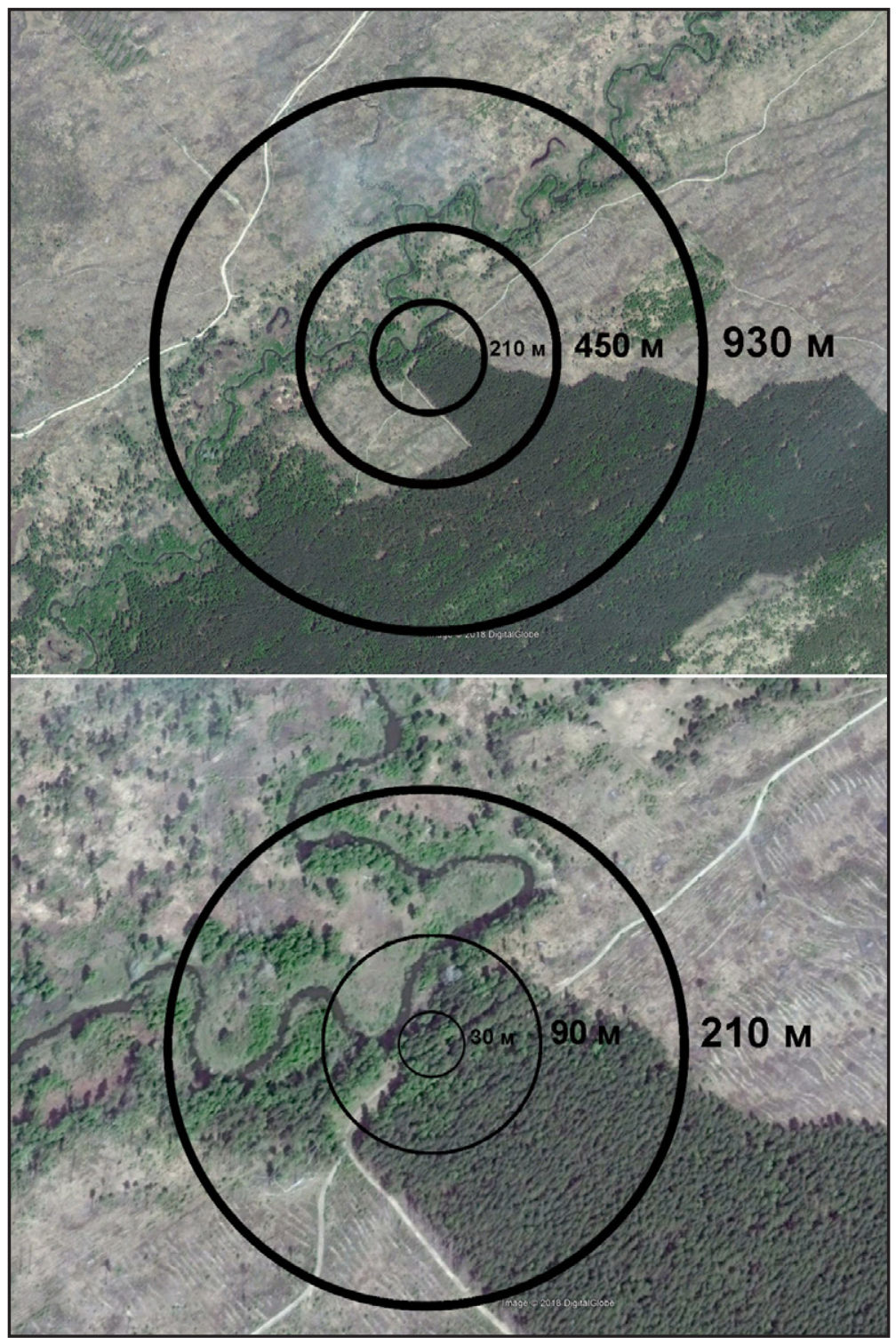

the Imperial Eagle, the Booted Eagle, the Black Kite, the Saker Falcon and the Merlin, for which FID is on the contrary higher by $11-60 \%$. That is, there are not so many species that have a noticeable response to a direct human disturbance factor higher than tolerance to habitat changes. Therefore, DD and DN may be a good validation for buffer zones. A certain minimum distance that is required to conserve the breeding territories of raptors can be a distance based on the difference between the minimum distance from the inhabited nest to the edge of the disturbance zone (DN-Lm) and the maximum distance from the abandoned nest to the edge of the disturbance zone (DD-M) (fig. 8, BZ-S in table 5). The maximum distance that sets the limits of a possible buffer zone around the nest of a bird of prey, should be determined based on the maximum values of FID and DD.

\section{Recommendations for SPFA parameters}

Some stable statutory SPFA parameters are required to exclude various speculations of allowed distances for felling near the nests of raptors. They could be used by forest users, including in the territories with no results of ornithologists' study.

In order to standardize SPFA parameters clear for forest users that do not know the species of birds, we offer 3 categories, determined by the size of nests that forest users can find during scheduled inspections of forest stands and withdrawal of timber cutting areas.

These categories are already given in a number of forest management regulations of forest areas in Russia and are taken into account by the Russian Raptor Research and Conservation Network on the biodiversity conservation in forest IBAs in the course of forestry activity:

- small nest - diameter up to $0.4 \mathrm{~m}$ - SPFA radius $150 \mathrm{~m}$ (BZ1 in fig. 8);

- midsized nest - diameter from 0.4 to 1 m. - SPFA radius $300 \mathrm{~m}$ (BZ2 in fig. 8);

- large nest - diameter $1 \mathrm{~m}$ and more SPFA radius $500 \mathrm{~m}$ (BZ3 in fig. 8).

During ornithological study and species identification of a nest for a Golden Eagle, Greater Spotted Eagle, or study of Eagle Owl nesting, SPFA radius should be increased to $800 \mathrm{~m}$ (BZ1 in fig. 8).

Since the Red Data Book of the Russian Federation subjects is the document that defines the protection of rare species in the region, region-specific parameters of SPFA allocation for each species must be included in it. 


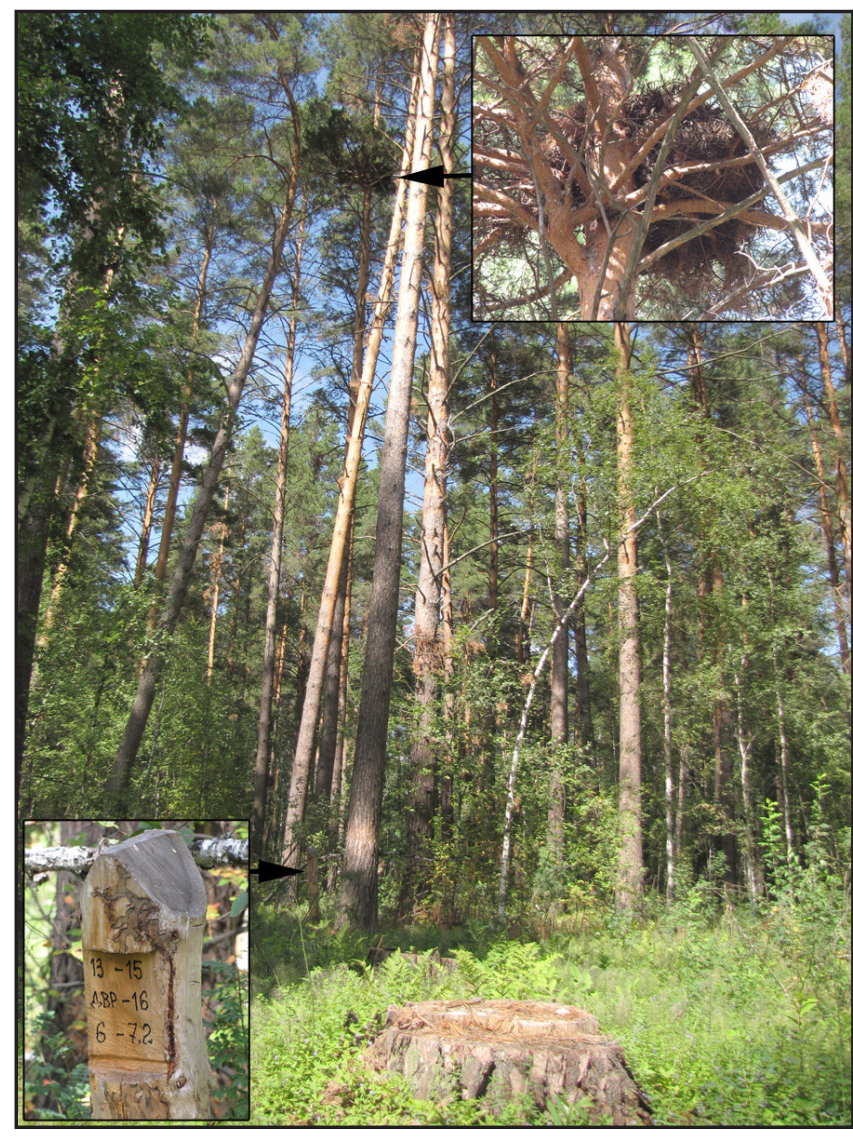

ми и изменение статуса гнёзд относительно этих нарушений не анамизироваии.

Аяя всех случаев нарушений регистрироваяи Аистанцию от гнезда $А$ зоны нарушения и тип нарушения. Аия рубок, по возможности (при обнаружении лесосечных столбиков), регистрировался виА рубки. Аия Аистанций от брошенного птицами гнезда $\Delta$ зоны нарушения принято сокрашение DD - от английского distance to disturbance. Опасная зона (DZ - от английского dangerous zone) рассчитывалась по максимамьной Аистанции от гнезАа $А$ края нарушения, на которой гнезАо покиламось птицами, в процессе или после произошедших нарушений. Аия Аистанций от жимого гнезда $\Delta о$ зоны нарушения, в случае если гнездо находится в опасной зоне, принято сокрашение DN - от английского dangerous neighborhood.

Гнёзда, в основе отхода которых лежами естественные причины (разрушение ветром, хишничество), мибо беспокойство, не связанное с лесопользованием (устройство пасек, временных стоянок и лагерей отдыха, браконьерство) в данной статье в учёт не брамись.

По совокупности полевых наблюдений лесных видов хишных птиц на 6315 гнездовых участках, мля которых были записаны поведенческие реакции, со-
Месосечный столбик, маркируюший рубку (внизу слева), и гнездо большого подорлика, брошенное в результате рубки хольингом "Аитайлес" на границе Аиеусского заказника в Аитайском крае. Фото И. Карякина.

The pole that marks woodcutting area, and nest of the Greater Spotted Eagle abandoned as a result of cutting by the holding "Altayles" on the border of the Aleus Nature Reserve (Altai Kray).

Photo by I. Karyakin.

ставлены таблицы дистанций, на которых регистрировалась реакция беспокойства птиц вплоть Ао момента вспугивания (FID) - 8219 наблюдений. Из них 1714 наблюАений одиночных птиц, преимушественно самцов, на гнездовых участках в период инкубации яиц, 1929 - в период выкарммивания птенцов, и 1996 и 2580 наблюАений взрослых птиц, преимушественно самок, на гнёздах в периоды насиживания киадки и выкармливания выводков соответственно.

Короткие Аистанции и высота присал определялись "на глаз" по окружаюшим элементам ландшаста (Аеревья, опоры АЭП), а также по фото и вилео в программе Range Finder (Khosravi, 2009) по формулам, основанным на метрических и угловых размерах объекта и фокусном расстоянии камеры (Гейдаров, 2011; Громазин и Ар., 2014; Аоктев, Аоктев, 2015), Аиинные Аистанции определялись по координатам, полученным с помошью GPS/ ГАОНАС навигаторов.

В ранний период исследований FID рассчитывачась нами $А$ основания присады или гнезда, с которого вспугивается птица (см. рис 2: дистанция Н), но с 2007 г. мы стаии фриксировать и высоту присахы и гнезда (6012 наблюдений), в соответствии с киассической методикой (см. Blumstein, 2006; Møller, 2010). Высота присад и гнёзд, с которых вспугиванись птицы, в нашей выборке варьирует от 0 (на земле) $\Delta$ о 50 м (на скале), составляя в среднем $(n=6012)$ $15 \pm 8,3$ м (рис. 4). Чтобы сравнивать собственные данные за разные периоды исслеАований, в Аанной работе мы оперируем понятием FID без учёта высоты присады или гнезда. Т.е. есии птица вспугиваяась с присады высотой 15 м при подходе человека к ней на дистанцию 1 м, мы считаем FID 1 м, а не 15 м. В случае если птица оставаяась на гнезде или присале при проходе человека под ней, FID считаии равным нулю вне зависимости от высоты присады или гнезда. Это нахо учитывать при сравнении наших 


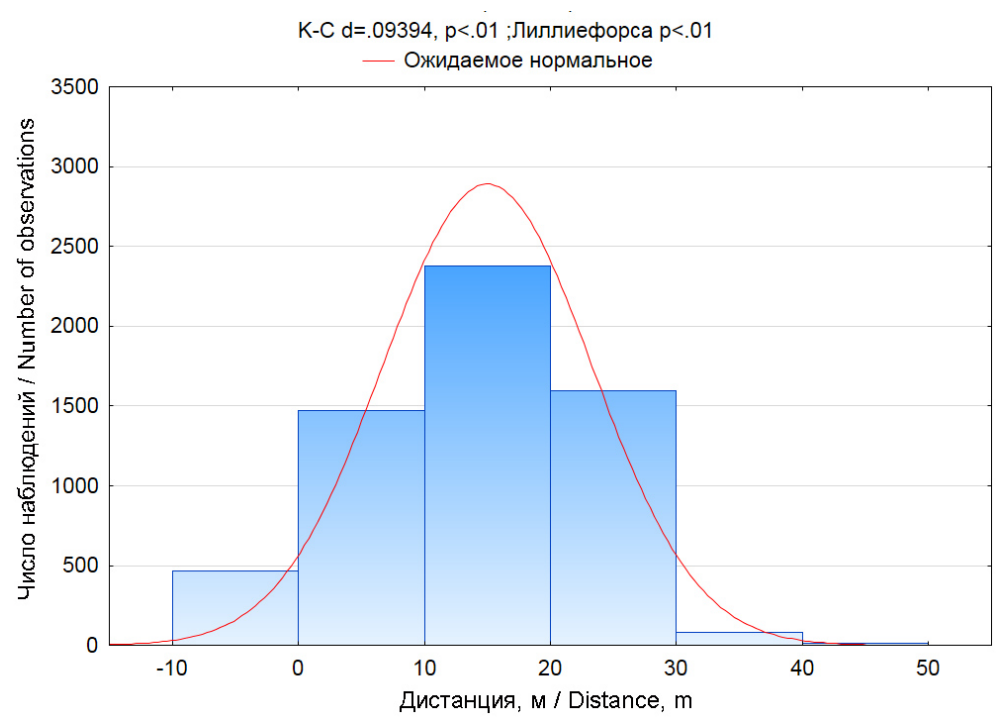

Аанных с данными зарубежных исследователей, если речь идёт о показателях FID $\Delta 0$ 50 м (наши показатели FID будут меньше таковых обшепринятых). При сравнении показателей FID более 50 м это теряет актуальность, так как высота присац лежит в пределах ошибки определения дистанций АО птицы с расстояний более 50 м.

Материал, собранный по FID стаи Аополнительным в качестве обоснования видоспецисических параметров вылеления ОЗУА на основе минимального раяиуса бусерной зоны (MAD от английского minimum approach distance) (см. Fox, Madsen, 1997).

Весь материаи по ответу хишных птиц на беспокойства и нарушения эпизодически собирался с 1991 по 2002 гг. и более или менее регулярно - с 2003 по 2016 гг. Основные точки сбора материала показаны на рис. 5.

Обработка результатов осушествлялась в программах MS Excel 2003 и Statistica 10. мя сравнения Аистанций использовами критерий Стьюдента (t-test) м^я независимых переменных.

Аля целей статьи также была проанамизирована зарубежная и российская митература, в которой приводятся Аанные о Аистанциях вспугивания птиц и параметрах охранных зон вокруг гнёзд хишных птиц. Выбирали и отдельно анамизировали утвержлённые нормативные акты и научные статьи. Большой материал был взят из наиболее полного обзора, слеланного американскими коммегами (Livezey et al., 2016):
Рис. 4. Высота присад и гнёзд, с которых вспугиваАись птицы с целью расчета FID.

Fig. 4. Height of perches and nests from which birds were flushed for the purposes of the study (for FID calculation).

- DOI: 10.3996/082015-JFWM-078.S1 (55 кБ XLSX) - опубликованные AD и FID мяя гнездяшихся птиц, собранные с 2009 по 2015 гг. ${ }^{146}$

- DOI: 10.3996/082015-JFWM-078.S2 (205 KB XLSX) - опубликованные AD и FID мяя негнездяшихся птиц, собранные с 2009 по 2015 гг. ${ }^{147}$; в обеих таблицах представлены следуюшие манные: авторы, район исследования, континент, источник беспокойства, таксономия и научное название вида, мля AD и FID Аанные вкАючают (при намичии) $M \pm S D$ или $M \pm S E$, Аиапазон, меАиану и число наблюдений (n), кроме того, Аанные вкАючают (при намичии) расстояние без вспугивания $(n)$ и Аолю вспугиваний от числа наблюдений (n).

- DOI: 10.3996/082015-JFWM-078.S3 (23 KB XLSX) - опубликованные MAD мля гнезАяшихся птиц с 2009 по 2015 гг. ${ }^{148}$

- DOI: 10.3996/082015-JFWM-078.S4 (28 KB XLSX) - опубликованные MAD мя негнезАяшихся птиц с 2009 по 2015 гг. ${ }^{149}$; в обеих таблицах представлены следуюшие Аанные: район исследования, континент, источник беспокойства, таксономия и научное название вида, MAD, формула MAD и цель её вылеления, ссылки на публикации.

\section{Результаты исследований и их обсуж- пение}

Аистанции вспугивания хищных птиц по результатам исследований авторов показаны в табл. 1.

Анамиз Аистанций вспугивания птиц показывает наибольшую толерантность к фактору беспокойства у взрослых птиц, сидящих на гнёздах (Аистанции вспугивания минимамьны), нежели у одиночных птиц на участках в некотором удалении от гнёзд как в период инкубации $(t=23,54$; $c c=3705 ; p<0,05)$, так и в период выкармиивания выводков ( $t=13,00 ; c c=4335$; $p<0,05)$. Связано это, определённо, с нежеланием птиц демаскировать гнездо. В частности, ряА скрытных виАОв сидит на гнёздах $\Delta о$ последнего, вылерживая про-

\footnotetext{
146 http://dx.doi.org/10.3996/082015-JFWM-078.S1

147 http://dx.doi.org/10.3996/082015-JFWM-078.S2

148 http://dx.doi.org/10.3996/082015-JFWM-078.S3

149 http://dx.doi.org/10.3996/082015-JFWM-078.S4
} 
ходы человека под гнездом. В то же время, реакция беспокойства на присутствие человека (AD) Ааже у плотно силяших на гнёздах Алиннохвостых неясытей наблюдается на Аистанциях значительно превышаюших дистанции вспугивания птицы с присады. К сожамению, нами эти параметры (AD) в большинстве случаев не регистрироваяись из-за определённой сложности их интерпретации. Аия ряла видов параметры AD и FID получены в Великобритании (Ruddock, Whitfield, 2007) и на них (см. табл. 2) можно ориентироваться, сравнивая с нашими Аанными.

В нашей выборке также отмечено увеАичение Аистанций вспугивания птиц с гнёзд в период выкармиивания птенцов, в отличие от периода инкубации $(t=-20,12$; $c c=4399 ; p<0,05)$. Интересно и то, что во второй половине лета (в период выкармливания птенцов) определённо возрастает Аистанция вспугивания взрослых птиц на участках, встреченных в удамении от гнёзА ( $t=-6,60 ; c c=3641 ; p<0,0005)$. Большинство взрослых птиц оАного и того же вида, и более того, одних и тех же птиц, встреченных в июне-июле сидящими на присалах в удамении от гнёзд, улетами, увидев наблюдателей, на более миинных Аистанциях, чем в апреле-мае. Возможно, здесь имеет место эрфрект, связанный с повторным беспокойством птиц. ОАнако большая часть наблюдений в выборке не принациежит тем же самым птицам, но демонстрирует те же тенденции. К тому же мяя некоторых видов (коршун, канюк) отмечено быстрое привыкание к регулярному посешению гнёзд, и даже при посе-

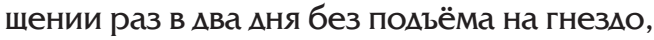
в течение месяца, Аистанции вспугивания сокрашались, как минимум, в два раза.
Как и следовало ожидать, максимальные Аистанции вспугивания (FID) характерны Аля крупных видов, таких как настояшие орлы (Aquila sp.) и орлан-белохвост (Haliaeetus albicilla), среди которых опремелённо мидирует беркут (Aquila chrysaetos) - 267,50 $\pm 125,48 \mathrm{M}$; lim 70-600 м. $\Delta$ иапазон дистанций вспугивания взросмых птиц у крупных хишников вне гнёзА Аостаточно близок и лежит в пределах от 150 Ао 300 м (табл. 1).

$\triangle$ истанции вспугивания птиц на гнёздах изменяются в зависимости от стратегии выбора мест мия гнездования. И более пугливым оказался орёл-могильник, большинство гнёзА которого ориентировано на открытые пространства $(224,30 \pm 125,69$ м; $\lim 10-550$ м), в то время как у беркута Аистанции вспугивания сокрашаются за счёт того, что гнёзда располагаются внутри массивов меса. В то же время, нацо понимать, что к регулярному беспокойству птицы привыкают, и, если орнитолог, разово появившийся на участке орла-могильника, вызывает у птицы беспокойство на максимамьно возможной Аистанции, то пастух, регулярно пасуший скот в районе гнезАа, может быть подпушен на дистанцию в 10 раз более короткую.

$\triangle$ истанции от гнёзд $А$ края зоны нарушений, на которых гнёзда покидаются хишными птицами (DD), приведены в табл. 3. Зона в 30 м от гнезда (вне зависимости от вида нарушений) является критической мля всех вилов пернатых хишников, как мелкого, так и крупного размерного киасса: 92,3 \% брошенных гнёзд в этой зоне ряАОм со сплошной рубкой, $100 \%$ - рялом с выборочной рубкой и 86,7 \% - на краю противопожарного разрыва или кинейного объекта, мля строительства которого
Рис. 5. Основные места исследований.

Fig. 5. Areas under study.

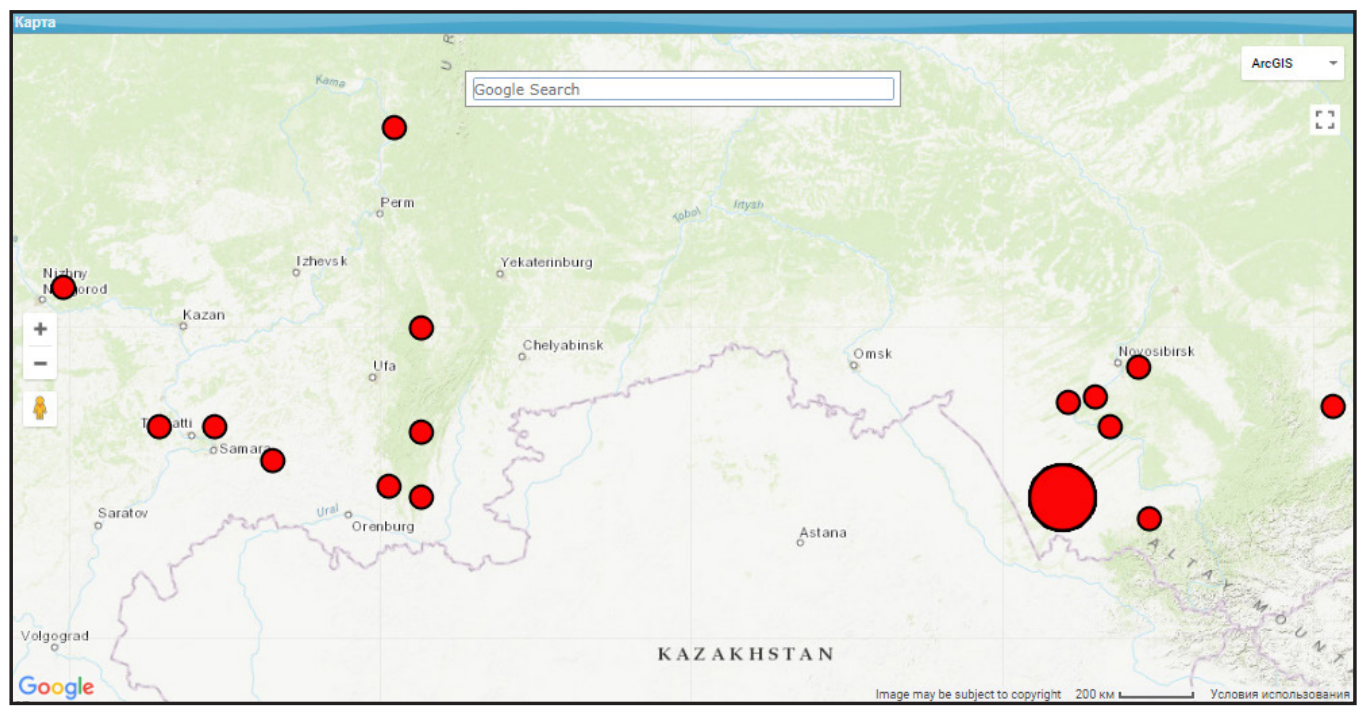


Tабл. 1, часть 1. Аистанции вспугивания (FID) месных видов хишных птиц (в метрах) по Аанным наблюдений в Республике Башкортостан, Пермской области, Новосибирской области, Алтайском крае, Республиках Алтай и Хакасия в 1991-2016 гг.

Table 1, part 1. Flight initiation distances (FID) for forest species of raptors (in meters), according to observations in the Republic of Bashkortostan, Perm and Novosibirsk regions, Altai Kray, Republics of Altai and Khakassia in 1991-2016.

Аистанция вспугивания (FID) взрослой птицы на гнезАовом участке вне гнезАа (в большинстве случаев самца) Flight initiation distance (FID) for the adult bird on the breeding territory outside the nest (in most cases, the male)

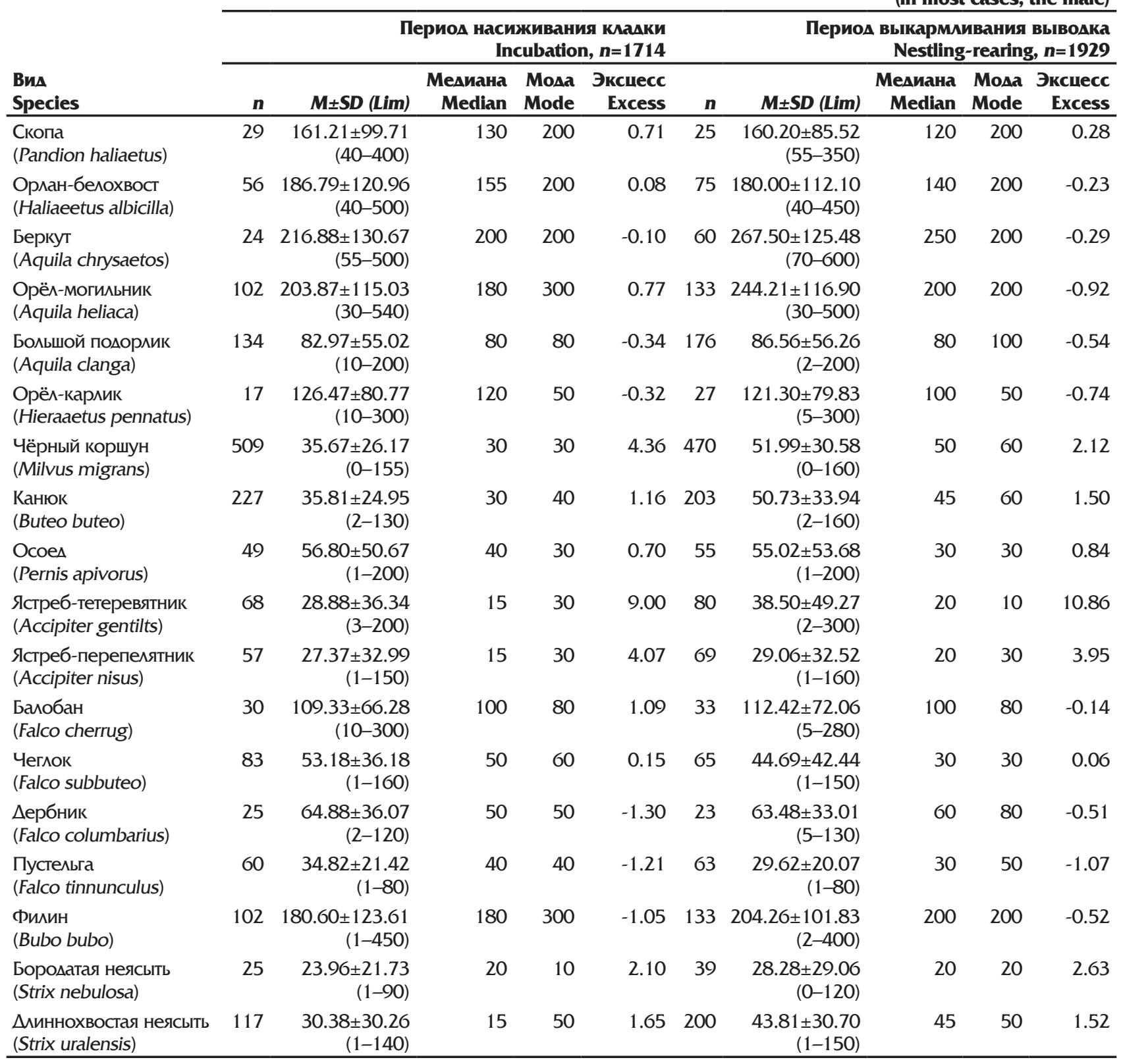

был вырублен лес (трасса, АЭП, газопровоА, оросительный или осушительный канам). Амя зоны 31-90 м от края нарушенного лесного сообщества уже наблюдается меньшее количество брошенных гнёзд - от 45-50 \%, до 81,45\%, а мия зоны 91-210 м - совсем незначительное: 0,18-7,12 \%. Причём основную статистику по реакциям Аают обычные виды мелкого и среднего размерного киасса, такие как ястреб-перепелятник (Accipiter nisus), чёрный коршун, обыкновенный канюк (Buteo buteo), ястреб-тетеревятник, Аииннохвостая неясыть. Если рассматривать такие крупные виды, как скопу (Pandion haliaetus), орлана-белохвоста, беркута, орла-могильника (Aquila heliaca), большого подорлика (Aquila clanga) и фрилина (Bubo bubo) в отдельности, то мия них зона критических нарушений отодвигается $А$ о 100 и более метров: от 92 Ао $100 \%$ брошенных гнёзА в зоне $\Delta$ о 90 м, от 1 мо $86 \%$ брошенных гнёзд в зоне от 91 до 210 м от гнезда. При этом на Аистанции $\Delta о 450$ м от края зоны 
Tабл. 1, часть 2. Аистанции вспугивания (FID) месных видов хишных птиц (в метрах) по Аанным наблюдений в Республике Башкортостан, Пермской области, Новосибирской области, Алтайском крае, Республиках Алтай и Хакасия в 1991-2016 гг.

Table 1, part 2. Flight initiation distances (FID) for forest species of raptors (in meters), according to observations in the Republic of Bashkortostan, Perm and Novosibirsk regions, Altai Kray, Republics of Altai and Khakassia in 1991-2016.

Аистанция вспугивания (FID) взрослой птицы на гнезАе (в большинстве случаев самки)

Flight initiation distance (FID) for the adult bird in the nest (in most cases, the female)

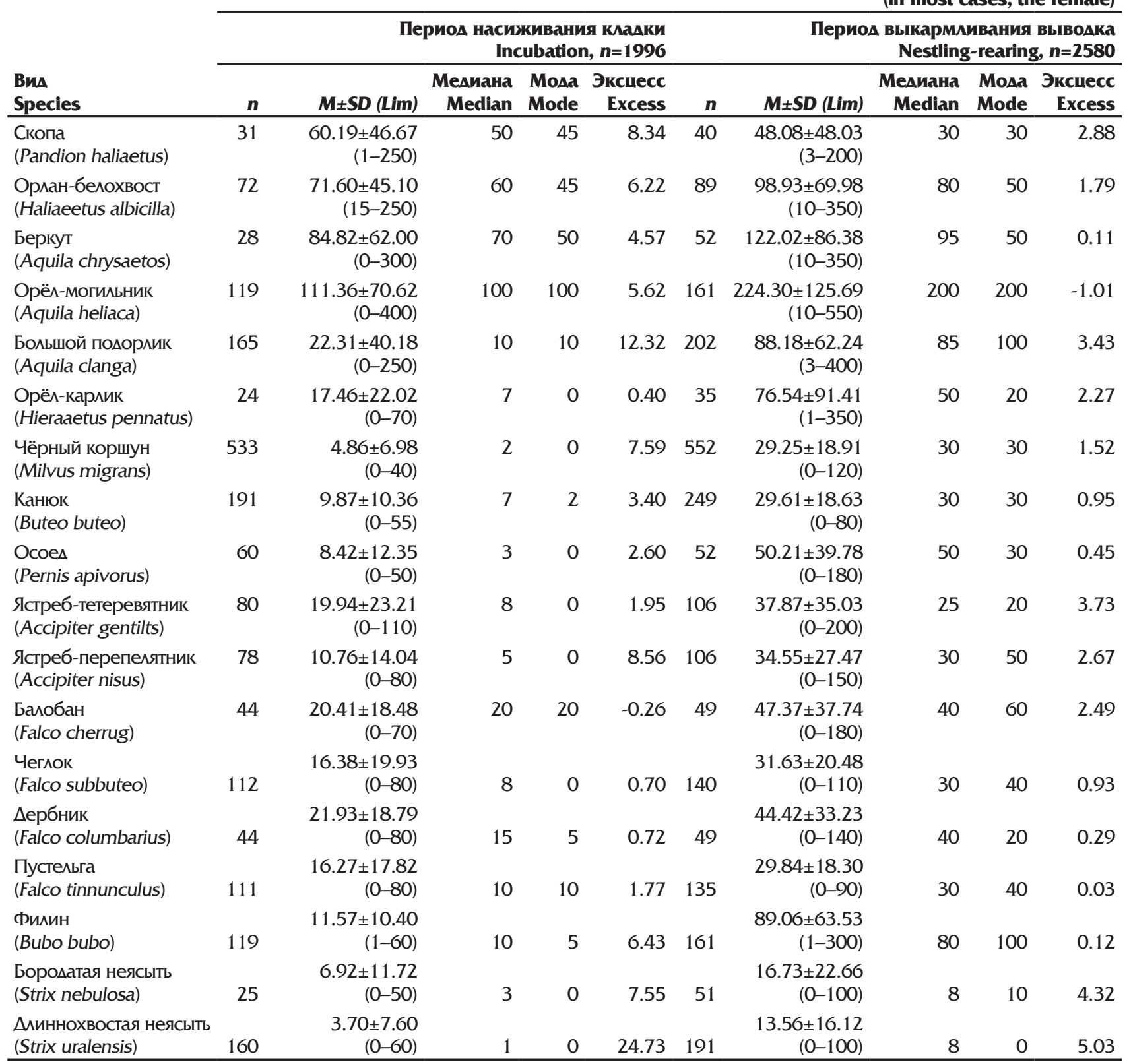

нарушений $А$ гнезда наблюдается $А$ о $6 \%$

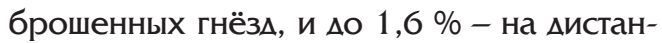
ции свыше 450 м. На дистанции свыше 450 м от края выборочной рубки были брошены 3 гнезда большого подорлика и 3 гнезда филина в Алтайских борах в связи с вырубкой всех крупных сосен на краю гнездового участка (край обширного водно-болотного комплекса). Подробная инсормация по реакции отдельных видов на типы нарушений дана в видовых очерках.
Из 555 наблюдений гнёзд хишных птиц в зоне влияния антропогенных нарушений структуры леса (DZ), Аишь 12,43\% остались занятыми птицами. Большая часть гнёзд $(87,57$ \%) была покинута птицами либо в тот же год, когАа произошло нарушение, мибо на следуюший, если нарушение случимось на поздних стациях выкармиивания птенцов или после сезона размножения (табл. 4). Аистанции, на которых наблюАамись жилые гнёзда (DN) в опасной зоне, показывают порог чувствительности вида 
Табл. 2. Итоговая статистическая информация по дистанциям до человека, вызываюшим беспокойство птиц (в метрах), из опроса экспертов: AD - Аистанция, на которой наблюдается беспокойство птицы, FID - Аистанция вспугивания птицы; по: Ruddосk, Whitfield, 2007.

Table 2. Summary descriptive statistics on alert distance $(\mathrm{m})$ for raptors exposed to disturbance caused by a humane presence. Data collected by an expert opinion survey: AD - 'alert distance' or 'static' disturbance distance, and FID - 'flight initiation distance' or 'active' disturbance distance. The distance category of the upper $90 \%$ of opinions is shown in the final column; from: Ruddock, Whitfield, 2007.

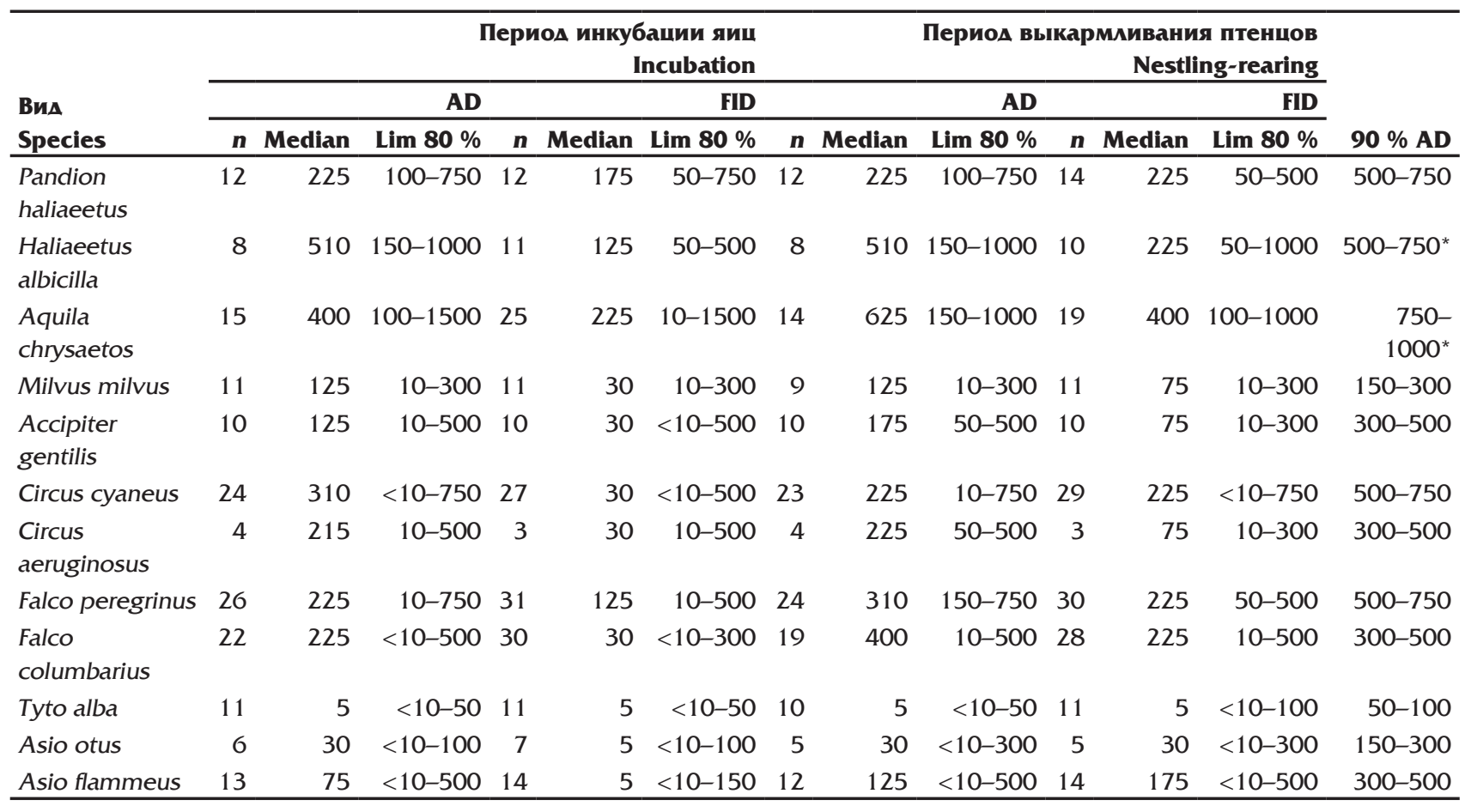

* представлены примеры, в которых максимальная Аистанция в расчёт не бралась из-за противоречивого мнения большинства респондентов;

* categories marked represented examples where the most extreme upper distance category was ignored because of blatantly contradictory majority opinion.

к нарушениям на его участках (рис. 6), и от них можно отталкиваться, как от минимально необходимых, мия сохранения того или иного виАа.

Соотношение показателей FID и DD показывает, что м^я проектирования буферных зон более корректно сравнивать средние значения FID с максимамьной Аистанцией от края зоны нарушений $А$ гнезАа птицы, на которой это гнездо оказывается брошенным (DD-M), так как средние значения DD Аемонстрируют кишь фактическую ситуацию с оставлением гнёзА птицами в какой-то зоне нарушений, а не пороговую чувствительность птиц к этим нарушениям (см. рис. 7, табл. 5).

Стоит отметить, что ^окамьные нарушения не всегла приводят к безвозвратному уходу вида с территории, на которой они произошки. Многолетний мониторинг за гнезАовыми участками, на которых гнёзда были брошены хишными птицами после провеАённых рялом рубок леса, показал, что на некоторые участки происходит "возврат" птиц. Причём, он происходит после рубки, которая не затронула гнездовое дерево и лес вокруг него в критической мля вила зоне (см. табл. 4). Конечно, при отсутствии мечения птиц, невозможно утвержАать, что на участок возврашаются те же самые птицы, поэтому слово "возврат" здесь не совсем корректно, тем не менее, мы далее будем использовать его мяя определения случаев повторного заселения тем же виАом участков, брошенных после рубок, так как лучшего термина найти не удалось.

Мы не зарегистрироваяи ни одного "возврата" скопы, беркута, орла-карлика (Hieraaetus pennatus) и балобана на свои прежние участки Ааже при сохранении гнездовых построек. Аия остальных видов Аоля "возвратов" составила от 5 Ао $30 \%$.

Пожалуй, мидером по возврашению на участки, затронутые рубками, как это ни странно, является орлан-белохвост - птицы вернулись на 30,4 \% брошенных участков (7 из 23-х). Практически все "возвраты" (5 из 7-ми) отмечены к гнёздам, которые были брошены птицами, после проведения рубок в 105-205 м от гнёзд. Во всех 5 случаях это были выборочные рубки (Алтайский край). В одном случае орланы 
Табл. 3. Аистанции от гнёзд хишных птиц до края зоны нарушений, по Аанным наблюдений в Республике Башкортостан, Пермской обмасти, Новосибирской области, Алтайском крае, Республиках Алтай и Хакасия в 1991-2016 гг.

Table 3. Distances from the raptor's nests to the edge of disturbances zone, according to observations in the Republic of Bashkortostan, Perm and Novosibirsk regions, Altai Kray, Republics of Altai and Khakassia in 1991-2016.

\begin{tabular}{|c|c|c|c|c|c|c|c|c|c|c|c|c|c|c|c|c|c|c|c|}
\hline \multirow[b]{2}{*}{$\begin{array}{l}\text { Bus } \\
\text { Species }\end{array}$} & \multirow[b]{2}{*}{$\begin{array}{l}\text { Статус гнезда } \\
\text { Nest status } \\
\end{array}$} & \multicolumn{6}{|c|}{$\begin{array}{r}\text { Спиошная рубка } \\
\text { Clearfelling } \\
\end{array}$} & \multicolumn{4}{|c|}{$\begin{array}{r}\text { Выборочная рубка } \\
\text { Selective felling }\end{array}$} & \multicolumn{6}{|c|}{$\begin{array}{r}\text { Аинейный объект (трасса, } \\
\text { АЭП, газопровод, канах) / } \\
\text { Linear disturbances } \\
\end{array}$} & \multirow{2}{*}{$\begin{array}{l}\text { BCEIO } \\
\text { TOTAL } \\
\end{array}$} & \multirow[b]{2}{*}{$\begin{array}{l}\text { Моля, \% } \\
\text { Share, \% }\end{array}$} \\
\hline & & $1-30$ & $\begin{array}{r}31- \\
90 \\
\end{array}$ & $\begin{array}{l}91- \\
210\end{array}$ & $\begin{array}{r}211- \\
450 \\
\end{array}$ & $>451$ & $1-30$ & $\begin{array}{r}31- \\
90\end{array}$ & $\begin{array}{l}91- \\
210\end{array}$ & $\begin{array}{r}211- \\
450 \\
\end{array}$ & $>451$ & $1 \quad 1-30$ & & 90 & $\begin{array}{l}91- \\
210\end{array}$ & $\begin{array}{r}211- \\
450 \\
\end{array}$ & $>451$ & & \\
\hline Скопа (Pandi- & - Брошено / Abandoned & - & 1 & 1 & 3 & & & 1 & 2 & & & & & & 1 & & & 9 & 15.79 \\
\hline $\begin{array}{l}\text { on haliaetus) } \\
n=57\end{array}$ & Занимается / Occupied & - & - & - & 3 & 45 & - & - & 1 & 47 & & - & - & - & - & 48 & - & 48 & 84.21 \\
\hline Орлан- & Брошено / Abandoned & - & 1 & 1 & 3 & & & 9 & 6 & & & & - & 3 & - & - & - & 23 & 29.11 \\
\hline $\begin{array}{l}\text { белохвост } \\
\text { (Haliaeetus } \\
\text { albicilla) } n=79\end{array}$ & Занимается / Occupied & - & - & - & - & 56 & - & - & 2 & 54 & & - & - & - & - & 56 & - & 56 & 70.89 \\
\hline Беркут & Брошено / Abandoned & - & 1 & & 2 & & & 6 & 1 & 4 & & - & - & 1 & - & - & - & 15 & 24.19 \\
\hline $\begin{array}{l}\text { (Aquila } \\
\text { chrysaetos) } \\
n=62\end{array}$ & Занимается / Occupied & - & - & - & - & 47 & & & & 1 & 46 & & & & 1 & 3 & 43 & 47 & 75.81 \\
\hline Opë^- & Брошено / Abandoned & - & 1 & - & - & - & 8 & 6 & 11 & - & & - & - & 4 & - & - & - & 30 & 15.23 \\
\hline $\begin{array}{l}\text { могильник } \\
\text { (Aquila heli- } \\
\text { aca) } n=197\end{array}$ & Занимается / Occupied & - & - & 34 & 133 & - & - & - & 2 & 165 & & - & - & - & 20 & 147 & - & 167 & 84.77 \\
\hline Большой & Брошено / Abandoned & 1 & 1 & 1 & - & - & 12 & 9 & 16 & 7 & & 3 & - & 2 & - & - & - & 52 & 24.07 \\
\hline $\begin{array}{l}\text { подорлик } \\
\text { (Aquila clan- } \\
\text { ga) } n=216\end{array}$ & Занимается / Occupied & - & - & - & 164 & - & - & - & 2 & 2 & 160 & & - & - & 164 & - & - & 164 & 75.93 \\
\hline Орёл-карлик & Брошено / Abandoned & - & - & - & - & - & 2 & - & 1 & - & & - & - & - & - & - & - & 3 & 11.54 \\
\hline $\begin{array}{l}\text { (Hieraaetus } \\
\text { pennatus) } \\
n=26\end{array}$ & Занимается / Occupied & - & - & - & 23 & - & - & - & - & 23 & & - & - & - & - & 23 & - & 23 & 88.46 \\
\hline Чёрный & Брошено / Abandoned & 2 & 3 & 1 & - & - & 24 & 50 & 8 & - & & - & 2 & 6 & - & - & - & 96 & 17.39 \\
\hline $\begin{array}{l}\text { коршун (Mil- } \\
\text { vus migrans) } \\
n=552\end{array}$ & Занимается / Occupied & - & 1 & 1 & 454 & - & - & 1 & 85 & 370 & & - & & 3 & 35 & 418 & - & 456 & 82.61 \\
\hline Канюк (Buteo & Брошено / Abandoned & 2 & 1 & - & - & - & 5 & 26 & - & - & & - & 5 & - & - & - & - & 39 & 15.35 \\
\hline buteo) $n=254$ & Занимается / Occupied & 1 & 13 & 201 & - & - & - & 8 & 207 & - & & - & 1 & 11 & 203 & - & - & 215 & 84.65 \\
\hline Ocoes (Pernis & Брошено / Abandoned & - & - & - & - & - & 3 & 5 & 2 & - & & - & 5 & - & - & - & - & 15 & 22.39 \\
\hline $\begin{array}{l}\text { apivorus) } \\
n=67\end{array}$ & Занимается / Occupied & - & - & 52 & - & - & & 1 & 17 & 34 & & - & 1 & 3 & 48 & - & - & 52 & 77.61 \\
\hline Ястреб-те- & Брошено / Abandoned & 1 & 2 & - & - & - & 7 & 20 & 4 & - & & - & - & 3 & - & - & - & 37 & 24.50 \\
\hline $\begin{array}{l}\text { теревятник } \\
\text { (Accipiter } \\
\text { gentilts) } \\
n=151\end{array}$ & Занимается / Occupied & - & 2 & 112 & - & - & - & - & 32 & 82 & & - & - & 7 & 107 & - & - & 114 & 75.50 \\
\hline Ястреб-пере- & Брошено / Abandoned & - & - & - & - & - & 8 & 4 & - & - & & - & - & - & - & - & - & 12 & 12.00 \\
\hline $\begin{array}{l}\text { пелятник } \\
\text { (Accipiter } \\
\text { nisus) } n=100\end{array}$ & Занимается / Occupied & - & - & 88 & - & - & - & 12 & 76 & - & & - & - & 3 & 85 & - & - & 88 & 88.00 \\
\hline Бамобан & Брошено / Abandoned & - & - & - & - & - & 1 & 4 & - & - & & - & - & 1 & - & - & - & 6 & 10.00 \\
\hline $\begin{array}{l}\text { (Falco cher- } \\
\text { rug) } n=60\end{array}$ & Занимается / Occupied & - & - & 54 & - & - & - & 1 & 53 & - & & - & - & - & 54 & - & - & 54 & 90.00 \\
\hline Чеглок (Falco & Брошено / Abandoned & - & - & - & - & - & 3 & 3 & - & - & & - & - & - & - & - & - & 6 & 3.19 \\
\hline $\begin{array}{l}\text { subbuteo) } \\
n=188\end{array}$ & Занимается / Occupied & - & - & 182 & - & - & - & 5 & 177 & - & & - & - & - & 182 & - & - & 182 & 96.81 \\
\hline Пустельга & Брошено / Abandoned & - & - & - & - & - & 2 & 1 & - & - & & - & - & - & - & - & - & 3 & 1.46 \\
\hline $\begin{array}{l}\text { (Falco tin- } \\
\text { nunculus) } \\
n=206\end{array}$ & Занимается / Occupied & - & - & 203 & - & - & - & 7 & 196 & - & & - & - & - & 203 & - & - & 203 & 98.54 \\
\hline Филин (Bubo & Брошено / Abandoned & 2 & - & 1 & - & - & 12 & 10 & 15 & 7 & & 3 & - & 2 & 1 & - & - & 53 & 24.09 \\
\hline bubo) $n=220$ & Занимается / Occupied & - & - & 2 & 39 & 126 & - & - & 1 & 4 & 162 & & - & 1 & 4 & 43 & 119 & 167 & 75.91 \\
\hline Бородатая & Брошено / Abandoned & 3 & 1 & 2 & - & - & 1 & 5 & 3 & - & - & - & - & - & - & - & - & 15 & 19.74 \\
\hline $\begin{array}{l}\text { неясыть (Strix } \\
\text { nebulosa) } \\
n=76\end{array}$ & Занимается / Occupied & - & - & 6 & 11 & 44 & & & 7 & 19 & 35 & 5 & & & & 11 & 50 & 61 & 80.26 \\
\hline Аииннохво- & Брошено / Abandoned & 1 & 4 & - & - & - & 34 & 21 & 1 & - & & - & 1 & 5 & - & - & - & 67 & 22.95 \\
\hline $\begin{array}{l}\text { стая неясыть } \\
\text { (Strix uralen- } \\
\text { sis) } n=292\end{array}$ & Занимается / Occupied & - & - & 45 & 71 & 109 & - & 6 & 55 & 77 & 87 & 7 & - & 5 & 33 & 72 & 115 & 225 & 77.05 \\
\hline \multirow[t]{2}{*}{$\begin{array}{l}\text { BCEIO } \\
\text { TOTAL }\end{array}$} & $\begin{array}{l}\text { Брошено } \\
\text { Abandoned }\end{array}$ & 12 & 16 & 7 & 8 & $\mathbf{0}$ & 122 & 180 & 70 & 18 & & 13 & 3 & 27 & 2 & 0 & 0 & 481 & 17.16 \\
\hline & $\begin{array}{l}\text { Занимается } \\
\text { Occupied }\end{array}$ & 1 & 16 & 980 & 898 & 427 & $\mathbf{0}$ & 41 & 913 & 878 & 490 & & 2 & 33 & 1139 & 821 & 327 & 2322 & 82.84 \\
\hline \multirow[t]{2}{*}{$\begin{array}{l}\text { Моля, \% } \\
\text { Share, \% }\end{array}$} & $\begin{array}{l}\text { Брошено } \\
\text { Abandoned }\end{array}$ & 92.31 & 50.00 & 0.71 & 0.88 & 0 & 100 & 81.45 & 7.12 & 2.01 & 1.21 & 186.67 & 745.0 & 00 & 0.18 & 0. & 0 & 17.16 & 17.16 \\
\hline & $\begin{array}{l}\text { Занимается } \\
\text { Occupied } \\
\end{array}$ & 7.69 & 50.00 & 99.29 & 99.12 & 100 & 0 & 18.55 & 92.88 & 97.99 & 98.79 & 913.33 & 355.0 & 009 & 99.82 & 100 & 100 & 82.84 & 82.84 \\
\hline
\end{tabular}




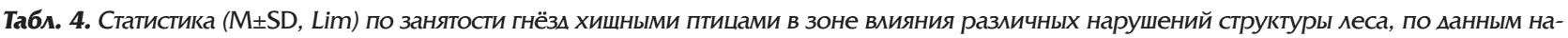
блюдений в Республике Башкортостан, Пермской области, Новосибирской области, Алтайском крае, Республиках Аитай и Хакасия в 19912016 гг. Условные обозначения: D - Аорога, G - газопровод, L - ^ЭП, O - осушительный канаи, P - противопожарный разрыв, $T$ - трасса.

Table 4. Statistics $(\mathrm{M} \pm \mathrm{SD}$, Lim) on occupation of nests by raptors in the zone of impact of different disturbances, according to observations in the Republic of Bashkortostan, Perm and Novosibirsk regions, Altai Kray, Republics of Altai and Khakasia in 1991-2016. Labels:D - road, G - gas pipeline, $L$ - power line, $O$ - drainage channel, $P$ - firebreak, $T$ - highway.

\begin{tabular}{|c|c|c|c|c|c|c|}
\hline \multirow[b]{2}{*}{$\begin{array}{l}\text { ВиА } \\
\text { Species }\end{array}$} & \multicolumn{3}{|c|}{ Сплошная рубка / Clearfelling } & \multicolumn{3}{|c|}{ Выборочная рубка / Selective felling } \\
\hline & $\begin{array}{r}\text { Брошено } \\
\text { Abandoned }\end{array}$ & $\begin{array}{r}\text { Занято } \\
\text { Occupied }\end{array}$ & $\begin{array}{r}\text { Опасная зона } \\
\text { Dangerous zone }\end{array}$ & $\begin{array}{r}\text { Брошено } \\
\text { Abandoned }\end{array}$ & $\begin{array}{r}\text { Занято } \\
\text { Occupied }\end{array}$ & $\begin{array}{r}\text { Oпасная зона } \\
\text { Dangerous zone }\end{array}$ \\
\hline $\begin{array}{l}\text { Скопа } \\
\text { (Pandion haliaetus) }\end{array}$ & $\begin{array}{r}n=5 \\
207.0 \pm 120.19 \\
(80-350)\end{array}$ & 0 & $\Delta 0350$ & $\begin{array}{r}n=3 \\
123.33 \pm 55.08 \\
(70-180)\end{array}$ & $\begin{array}{r}n=1 \\
90\end{array}$ & $\Delta \mathrm{O} 180,(?)$ \\
\hline $\begin{array}{l}\text { Орлан-белохвост } \\
\text { (Haliaeetus albicilla) }\end{array}$ & $\begin{array}{r}n=5 \\
249.2 \pm 166.11 \\
(50-426)\end{array}$ & 0 & $\Delta 0426$ & $\begin{array}{r}n=15 \\
83.87 \pm 31.24 \\
(25-205)\end{array}$ & $\begin{array}{r}n=2 \\
152.5 \pm 67.18 \\
(105-200)\end{array}$ & $\triangle 0205$ \\
\hline $\begin{array}{l}\text { Беркут } \\
\text { (Aquila chrysaetos) }\end{array}$ & $\begin{array}{r}n=3 \\
245.0 \pm 202.92 \\
(35-440)\end{array}$ & 0 & $\Delta O 440,(?)$ & $\begin{array}{r}n=11 \\
153.36 \pm 114.04 \\
(77-420)\end{array}$ & $\begin{array}{l}n=1 \\
410\end{array}$ & $\Delta 0420-650^{* * *}$ \\
\hline $\begin{array}{l}\text { Oрёл-могильник } \\
\text { (Aquila heliaca) }\end{array}$ & $\begin{array}{r}n=1 \\
45\end{array}$ & 0 & (?) & $\begin{array}{r}n=25 \\
81.32 \pm 61.30 \\
(7-207)\end{array}$ & $\begin{array}{r}n=2 \\
153.0 \pm 50.91 \\
(117-189)\end{array}$ & $\triangle 0207$ \\
\hline $\begin{array}{l}\text { Большой подорлик } \\
\text { (Aquila clanga) }\end{array}$ & $\begin{array}{r}n=3 \\
66.67 \pm 49.32 \\
(13-110)\end{array}$ & 0 & $\Delta \mathrm{O} 110,(?)$ & $\begin{array}{r}n=47 \\
151.53 \pm 156.80 \\
(3-650)\end{array}$ & $\begin{array}{r}n=6 \\
361.83 \pm 182.74 \\
(126-610)\end{array}$ & $\Delta 0650$ \\
\hline $\begin{array}{l}\text { Oрёл-карлик } \\
\text { (Hieraaetus pennatus) }\end{array}$ & 0 & 0 & нет Аанных & $\begin{array}{r}n=3 \\
50.0 \pm 48.22 \\
(15-105)\end{array}$ & 0 & $\Delta \mathrm{O} 105-200^{* * *},(?)$ \\
\hline $\begin{array}{l}\text { Чёрный коршун } \\
\text { (Milvus migrans) }\end{array}$ & $\begin{array}{r}n=6 \\
48.33 \pm 34.80 \\
(7-105)\end{array}$ & $\begin{array}{r}n=2 \\
88.50 \pm 2.12 \\
(87-90)\end{array}$ & $\Delta 0105$ & $\begin{array}{r}n=82 \\
51.62 \pm 29.47 \\
(1-107)\end{array}$ & $\begin{array}{r}n=7 \\
96.86 \pm 11.01 \\
(73-105)\end{array}$ & $\Delta \mathrm{O} 110$ \\
\hline $\begin{array}{l}\text { Канюк обыкновенный } \\
\text { (Buteo buteo) }\end{array}$ & $\begin{array}{r}n=3 \\
15.67 \pm 4.04 \\
(12-20)\end{array}$ & $\begin{array}{r}n=1 \\
19\end{array}$ & $\Delta \mathrm{O} 20-70^{* * *}$ & $\begin{array}{r}n=31 \\
53.68 \pm 23.38 \\
(1-84)\end{array}$ & $\begin{array}{r}n=4 \\
75.75 \pm 4.35 \\
(70-80)\end{array}$ & $\Delta 084$ \\
\hline $\begin{array}{l}\text { ОсоеА обыкновенный } \\
\text { (Pernis apivorus) }\end{array}$ & 0 & 0 & $\begin{array}{r}\text { нет данных } \\
\text { no data }\end{array}$ & $\begin{array}{r}n=10 \\
53.70 \pm 40.90 \\
(1-120)\end{array}$ & $\begin{array}{r}n=2 \\
77.62 \pm 31.68 \\
(80-110)\end{array}$ & $\Delta \mathrm{O} 120$ \\
\hline $\begin{array}{l}\text { Ястреб-тетеревятник } \\
\text { (Accipiter gentilts) }\end{array}$ & $\begin{array}{r}n=3 \\
41.33 \pm 30.09 \\
(10-70)\end{array}$ & $\begin{array}{r}n=1 \\
58\end{array}$ & $\Delta \mathrm{O} 70$ & $\begin{array}{r}n=31 \\
53.74 \pm 32.19 \\
(1-112)\end{array}$ & $\begin{array}{r}n=4 \\
99.5 \pm 4.20 \\
(95-105)\end{array}$ & $\Delta \mathrm{O} 112$ \\
\hline $\begin{array}{l}\text { Ястреб-перепемятник } \\
\text { (Accipiter nisus) }\end{array}$ & 0 & 0 & $\begin{array}{r}\text { нет данных } \\
\text { no data }\end{array}$ & $\begin{array}{r}n=12 \\
21.0 \pm 19.34 \\
(1-60)^{* *}\end{array}$ & $\begin{array}{r}n=4 \\
54.25 \pm 3.50 \\
(50-58)^{* *}\end{array}$ & $\Delta 060$ \\
\hline $\begin{array}{l}\text { Бамобан } \\
\text { (Falco cherrug)* }^{*}\end{array}$ & 0 & 0 & $\begin{array}{r}\text { нет данных } \\
\text { no data }\end{array}$ & $\begin{array}{r}n=5 \\
48.4 \pm 25.22 \\
(12-82)\end{array}$ & $\begin{array}{r}n=1 \\
80\end{array}$ & $\Delta \mathrm{O} 82-100^{* * *}$ \\
\hline $\begin{array}{l}\text { Чеглок } \\
\text { (Falco subbuteo)* }^{*}\end{array}$ & 0 & 0 & $\begin{array}{r}\text { нет } \Delta \text { анных } \\
\text { no data }\end{array}$ & $\begin{array}{r}n=6 \\
28.83 \pm 23.11 \\
(1-57)\end{array}$ & $\begin{array}{r}n=2 \\
52.5 \pm 3.54 \\
(50-55)\end{array}$ & $\Delta 060$ \\
\hline $\begin{array}{l}\text { Пустельга обыкновенная } \\
\text { (Falco tinnunculus)* }^{*}\end{array}$ & 0 & 0 & $\begin{array}{r}\text { нет данных } \\
\text { no data }\end{array}$ & $\begin{array}{r}n=3 \\
22.0 \pm 19.97 \\
(5-44)\end{array}$ & 0 & $\Delta \mathrm{O} 50,(?)$ \\
\hline $\begin{array}{l}\text { Филин } \\
\text { (Bubo bubo) }\end{array}$ & $\begin{array}{r}n=3 \\
44.0 \pm 49.33 \\
(7-100)\end{array}$ & 0 & $\Delta \mathrm{O} 100,(?)$ & $\begin{array}{r}n=47 \\
150.0 \pm 154.48 \\
(1-607)\end{array}$ & $\begin{array}{r}n=8 \\
371.25 \pm 168.28 \\
(105-600)\end{array}$ & $\Delta 0607$ \\
\hline $\begin{array}{l}\text { Бородатая неясыть } \\
\text { (Strix nebulosa) }\end{array}$ & $\begin{array}{r}n=6 \\
59.67 \pm 51.01 \\
(3-115)\end{array}$ & $\begin{array}{r}n=1 \\
95\end{array}$ & $\Delta \mathrm{O} 115$ & $\begin{array}{r}n=9 \\
75.44 \pm 38.81 \\
(22-126)\end{array}$ & $\begin{array}{r}n=2 \\
100.5 \pm 6.36 \\
(96-105)\end{array}$ & $\Delta \mathrm{O} 126$ \\
\hline $\begin{array}{l}\text { Аиннохвостая неясыть } \\
\text { (Strix uralensis) }\end{array}$ & $\begin{array}{r}n=5 \\
52.6 \pm 21.63 \\
(15-70)\end{array}$ & 0 & $\Delta \mathrm{O} 70$ & $\begin{array}{r}n=56 \\
32.96 \pm 23.79 \\
(1-103)\end{array}$ & $\begin{array}{r}n=8 \\
82.75 \pm 14.43 \\
(55-100)\end{array}$ & $\Delta \mathrm{O} 105$ \\
\hline
\end{tabular}

\section{Примечание / Note:}

* - в анализ вкиючены только гнёзда, попавшие в зону рубок в гнездовой период, когАа можно было однозначно идентисицировать их занятость до момента проведения рубки (брошенные гнёзда идентисрицированы по погибшим киадкам и выводкам) / in the analysis included only the nests that were into the the felling zone in the nesting period, when it was possible to define unambiguously their occupation until the felling (the abandoned nests were identified on dead masonry and broods),

** - вместе с выборочными рубками учтены рубки ухода, так как большая часть гнёзд, попавших в анализ, была устроена в культурах сосны и ели мо 30 летнего возраста / together with selective felling, care felling was taken into account, because most of the nests included in the analysis were located in pine and spruce forest cultures until the age of 30 ,

*** - в выборке нет гнёзд в данном диапазоне дистанций от края нарушения / among the surveyed nests there are no nests in this range of distances from the disturbances boundaries,

(?) - данных недостаточно / insufficient data. 


\begin{tabular}{|c|c|c|}
\hline \multicolumn{3}{|c|}{ Линейное нарушение / Linear disturbances } \\
\hline $\begin{array}{r}\text { Брошено } \\
\text { Abandoned }\end{array}$ & $\begin{array}{r}\text { Занято } \\
\text { Occupied } \\
\end{array}$ & $\begin{array}{r}\text { Oпасная зона } \\
\text { Dangerous zone }\end{array}$ \\
\hline $\begin{array}{r}n=1 \\
160(\mathrm{G})\end{array}$ & 0 & $(?)$ \\
\hline $\begin{array}{r}n=3 \\
83.33 \pm 5.69(77-88) \\
(G, T)\end{array}$ & 0 & $\triangle 088,(?)$ \\
\hline $\begin{array}{r}n=1 \\
56(\text { (ЭЭП) }\end{array}$ & 0 & (?) \\
\hline $\begin{array}{r}n=4 \\
61.75 \pm 21.52(35-82) \\
(G, T)\end{array}$ & 0 & $\triangle 082,(?)$ \\
\hline $\begin{array}{r}n=2 \\
64.0 \pm 19.80(50-78) \\
(T, P)\end{array}$ & 0 & $\Delta \mathrm{O} 78,(?)$ \\
\hline 0 & 0 & $\begin{array}{r}\text { нет данных } \\
\text { no data }\end{array}$ \\
\hline $\begin{array}{r}n=8 \\
44.63 \pm 23.15 \\
(3-85)\end{array}$ & $\begin{array}{r}n=3 \\
71.33 \pm 8.08 \\
(64-80)\end{array}$ & $\Delta \mathrm{O} 85,(?)$ \\
\hline $\begin{array}{r}n=5 \\
15.2 \pm 7.73 \\
(5-26)\end{array}$ & $\begin{array}{r}n=1 \\
20 \\
(\mathrm{~L})\end{array}$ & $\Delta 060^{* * *}$ \\
\hline $\begin{array}{r}n=5 \\
42.4 \pm 27.57 \\
(4-80)\end{array}$ & $\begin{array}{r}n=1 \\
60 \text { (ЛЭП) }\end{array}$ & $\Delta \mathrm{O} 80$ \\
\hline $\begin{array}{r}n=3 \\
42.67 \pm 10.79 \\
(35-55)\end{array}$ & $\begin{array}{r}n=1 \\
50 \\
(P)\end{array}$ & Ао 55, (?) \\
\hline 0 & 0 & $\begin{array}{r}\text { нет данных } \\
\text { no data }\end{array}$ \\
\hline $\begin{array}{r}n=1 \\
45 \\
(\mathrm{~L})\end{array}$ & 0 & (?) \\
\hline 0 & 0 & $\begin{array}{r}\text { нет данных } \\
\text { no data }\end{array}$ \\
\hline 0 & 0 & $\begin{array}{r}\text { нет данных } \\
\text { no data }\end{array}$ \\
\hline $\begin{array}{r}n=3 \\
78.0 \pm 33.05(44-110) \\
(D, L, O)\end{array}$ & $\begin{array}{r}n=1 \\
90 \\
(P)\end{array}$ & $\Delta \mathrm{O} 110,(?)$ \\
\hline 0 & 0 & $\begin{array}{r}\text { нет данных } \\
\text { no data }\end{array}$ \\
\hline $\begin{array}{r}n=6 \\
43.67 \pm 21.21 \\
(5-65)\end{array}$ & $\begin{array}{r}n=3 \\
51.33 \pm 10.26(40-60) \\
(L, G, P)\end{array}$ & $\Delta 065$ \\
\hline
\end{tabular}

вернулись на участок, в 400-х м от которого была проведена сплошная рубка (Пермская область) и в одном случае на участок, в 88 м от которого была проложена дорога (пойма р. Белая, Башкирия). ОАна пара орланов вернулась на третий год в то же гнездо (Аитайский край), остальные - через 5-7 лет и кишь в Авух случаях в свои гнёзда (Башкирия и Алтайский край).

У больших подорликов из выборки в 52 гнезда, брошенных после рубок, только на трёх (5,77 \%) птицы "вернулись" на 7-й, 9-й и 10-й год после нарушения (после того, как произошёл подъём подроста ^еса на участках). Причём во всех случаях птицы строили новые гнёзда, так как старые были полностью или частично разрушены, мибо заняты Аругими видами (в основном коршунами). Все "возвраты" птиц произошли на участках с диапазоном дистанций 207-405 м от места расположения прежних гнёзА $А$ границы зоны нарушений.

Аучше обстоит ситуация с филином, мля которого зарегистрировано 16 "возвратов" при 55 случаях оставления мест гнездования. Но, тем не менее, это всё равно очень низкий уровень восстановления участков, при том, что виА не ограничен крупными Аеревьями мия устройства гнёзд, так как гнездится на земле, а в последнее время в борах Алтайского края испытывает тенденцию к гнездованию в более молодых участках леса под соснами небольшого Аиаметра, ацаптируясь к регумярным рубкам на его участках (Карякин, 2014). Аишь одна пара вернулась на свой участок на следуюший год, после того, как во время Аобровольно-выборочной рубки годом ранее у неё была уничтожена киалка. Остальные участки повторно были заняты филинами через 3-6 лет - все они восстановились на участках с миапазоном Аистанций от 100 Ао 500 м от прежних гнёзд $\Delta$ края лесных вылелов, пройденных Аобровольно-выборочными рубками.

У обычных хишников - коршуна (97 брошенных гнёзА) и канюка (39 брошенных гнёзs) - отмечено 27,84 \% и 20,51\% "возвратов" на свои участки после выборочных рубок.

Многолетний мониторинг за гнездовыми участками показая, что при минимамьных нарушениях (выборочная рубка в одном вылеле, противопожарные мероприятия или строительство минейного объекта) и Аостаточно большой плошади гнездопригодных биотопов, хишные птицы не бросают участки, а мишь смешаются подаиьше от зоны нарушения, устраивая гнездо в новом 
Рис. б. Аистанции от гнёзА хищных птиц $А$ О границы зоны нарушений. DN - Аистанция от гнезда $А$ края зоны нарушения на которой гнездо всё ешё занято хищными птицами: $D N-A v-$ среАняя Аистанция, DN-Lm минимамьная Аистанция; DD - Аистанция от гнезда, Ао края зонь нарушения, на которой гнездо брошено хишными птицами: $D D-A v$ - средняя Аистанция, DD-M - максимамьная Аистанция.

Fig. 6. Distances from the raptor nests to the edge of the disturbances zones. DN - distance from the nest to the edge of the disturbance zone on which nest is still occupied by birds: DN-Av - average distance, DN-Lm minimum distance; $D D$ - distance from the nest to the edge of the disturbances zone in which nest was abandoned by birds: $D D-A v$ - average distance, $D D-M-$ maximum distance.

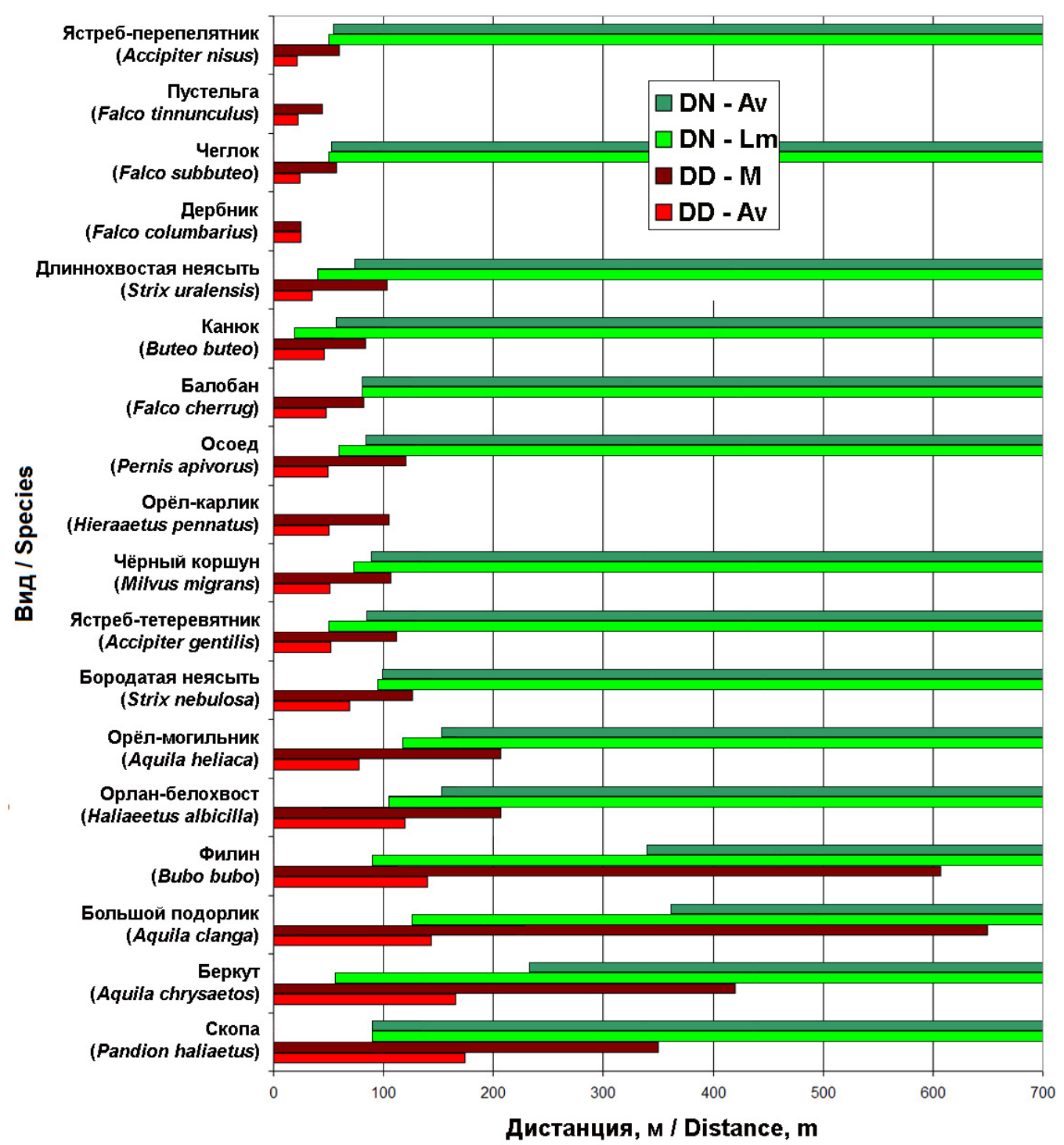

месте. Однако при мамых плошалях гнезАопригодных биотопов происходит прекрашение гнездования птиц на участке, что наглянно демонстрируют беркут и фимин в борах Аитайского края (Важков, Рыбамьченко, 2013; Карякин, 2014; Карякин, Николенко, 2015а). Какие площали гнезАопригодных биотопов позволяют хишникам сохранять свои гнездовые участки при определённых нарушениях структуры леса, до сих пор неизвестно - этот вопрос требует Ааиьнейшего изучения.

Оставление участка одним видом, иногАа приводит к его оккупации Аругим, как правило, более слабым конкурентом, но более толерантным к конкретным нарушениям. Наглядным примером является исчезновение беркута на многолетнем гнездовом участке в Корниловском заказнике (А^тайский край), после рубки, проведённой в 420 м от гнезАа (Карякин, Николенко, 2015а). На следуюший год это гнездо занял большой подорлик, оказав- шийся более толерантным к ведушимся на краю гнездового участка рубкам (Карякин, Николенко, 2015b), а беркуты покинуми территорию. Аналогичным образом 7 гнездовых построек подорликов, брошенных по причине ведушихся рядом рубок, были в Аальнейшем заняты коршунами. Казалось бы, гнездо остаётся занятым хишной птицей, однако, вместо более редкого и угрожаемого в Аанном районе вила, участок занимает более обычный, что ведёт к обеднению фаунистического комплекса Аанной территории.

Несмотря на Аостаточно большой материал по нарушениям структуры леса на гнездовых участках хишных птиц, не уда^ось корректно ответить на вопрос о наибольшей опасности тех или иных видов нарушений. Связано это в первую очередь с тем, что основным видом нарушений в анализируемой выборке являются выборочные рубки - 82 \% от 555 наблюдений в зоне влияния нарушения. 
Табл. 5. Параметры, важные мя проектирования буферных зон вокруг гнёзд, хишных птиц. Сокрашения: DD - 4 истанция от гнезАа, $\Delta о$ края зоны нарушения, на которой гнездо брошено хишными птицами (DD-Av - средняя Аистанция), DN - $\Delta$ истанция от гнезАа, $\Delta$ о края зоны нарушения, на которой гнездо всё ешё занято хишными птицами, FID - Аистанция вспугивания (FID-B - $\Delta$ птицы на присаце в период выкармливания птенцов), BZ-S - минимальный радиус возможной буферной зоны.

Table 5. Important parameters for designing buffer zones around raptor nests. Abbreviations: DD - distance from the nest to the edge of the disturbances zone in which nest was abandoned by birds (DD-Av-average distance), DN - distance from the nest to the edge of the disturbance zone on which nest is still occupied by birds, FID - flight initiation distance (FID-B - for bird on a perch during nestling-rearing period), BZ-S - minimum radius of the possible buffer zone.

\begin{tabular}{|c|c|c|c|c|c|c|c|c|c|c|c|}
\hline \multirow[b]{2}{*}{$\begin{array}{l}\text { Вих } \\
\text { Species }\end{array}$} & \multicolumn{2}{|l|}{ DD } & \multicolumn{2}{|l|}{ DN } & \multicolumn{4}{|l|}{ FID } & \multirow[b]{2}{*}{$\begin{array}{l}\text { FID-B : } \\
\text { DD-Av }\end{array}$} & \multirow[b]{2}{*}{$\begin{array}{r}\text { FID-B : } \\
\text { DD-M }\end{array}$} & \multirow[b]{2}{*}{ BZ-S } \\
\hline & 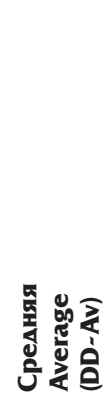 & 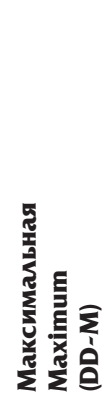 & 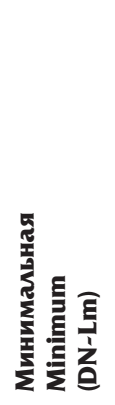 & 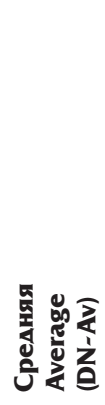 & 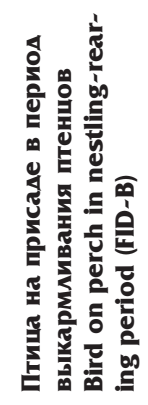 & 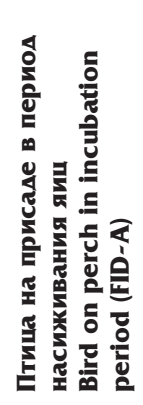 & 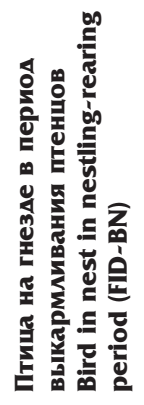 &  & & & \\
\hline $\begin{array}{l}\text { Скопа } \\
\text { (Pandion haliaetus) }\end{array}$ & 173.89 & 350 & 90 & 90 & 160.20 & 161.21 & 48.08 & 60.19 & 0.92 & 0.46 & 220 \\
\hline $\begin{array}{l}\text { Беркут } \\
\text { (Aquila chrysaetos) }\end{array}$ & 165.2 & 420 & 56 & 233 & 267.50 & 216.88 & 122.02 & 84.82 & 1.62 & 0.64 & 238 \\
\hline $\begin{array}{l}\text { Большой подорлик } \\
\text { (Aquila clanga) }\end{array}$ & 143.27 & 650 & 126 & 361.83 & 86.56 & 82.97 & 88.18 & 22.31 & 0.60 & 0.13 & 388 \\
\hline $\begin{array}{l}\text { Филин } \\
\text { (Bubo bubo) }\end{array}$ & 139.92 & 607 & 90 & 340 & 204.26 & 180.6 & 89.06 & 11.57 & 1.46 & 0.34 & 349 \\
\hline $\begin{array}{l}\text { Орлан-белохвост } \\
\text { (Haliaeetus albicilla) }\end{array}$ & 119.74 & 205 & 105 & 152.5 & 180.00 & 186.79 & 98.93 & 71.6 & 1.50 & 0.88 & 155 \\
\hline $\begin{array}{l}\text { Oрёл-могильник } \\
\text { (Aquila heliaca) }\end{array}$ & 77.5 & 207 & 117 & 153 & 244.21 & 203.87 & 224.3 & 111.36 & 3.15 & 1.18 & 162 \\
\hline $\begin{array}{l}\text { Бородатая неясыть } \\
\text { (Strix nebulosa) }\end{array}$ & 69.13 & 126 & 95 & 98.67 & 28.28 & 23.96 & 16.73 & 6.92 & 0.41 & 0.22 & 111 \\
\hline $\begin{array}{l}\text { Ястреб-тетеревятник } \\
\text { (Accipiter gentilts) }\end{array}$ & 51.84 & 112 & 50 & 84.33 & 38.50 & 27.37 & 37.87 & 19.94 & 0.74 & 0.34 & 81 \\
\hline $\begin{array}{l}\text { Чёрный коршун } \\
\text { (Milvus migrans) }\end{array}$ & 50.83 & 107 & 73 & 89.08 & 52.00 & 35.67 & 29.25 & 4.86 & 1.02 & 0.49 & 90 \\
\hline $\begin{array}{l}\text { Oрёл-карлик } \\
\text { (Hieraaetus pennatus) }\end{array}$ & 50 & 105 & & & 121.30 & 126.47 & 76.54 & 17.46 & 2.43 & 1.16 & ? \\
\hline $\begin{array}{l}\text { ОсоеА обыкновенный } \\
\text { (Pernis apivorus) }\end{array}$ & 49.93 & 120 & 60 & 83.33 & 55.02 & 56.8 & 50.21 & 8.42 & 1.10 & 0.46 & 90 \\
\hline $\begin{array}{l}\text { Балобан } \\
\text { (Falco cherrug) }\end{array}$ & 47.83 & 82 & 80 & 80 & 112.42 & 109.33 & 47.37 & 20.41 & 2.35 & 1.37 & 81 \\
\hline $\begin{array}{l}\text { Канюк обыкновенный } \\
\text { (Buteo buteo) }\end{array}$ & 45.82 & 84 & 19 & 57 & 50.73 & 35.81 & 29.61 & 9.87 & 1.11 & 0.60 & 52 \\
\hline $\begin{array}{l}\text { Аиннохвостая неясыть } \\
\text { (Strix uralensis) }\end{array}$ & 35.39 & 103 & 40 & 74.18 & 43.81 & 30.38 & 13.56 & 3.7 & 1.24 & 0.43 & 72 \\
\hline $\begin{array}{l}\text { Аербник } \\
\text { (Falco columbarius) }\end{array}$ & 25 & 25 & & & 63.48 & 64.88 & 44.42 & 21.93 & 2.54 & 2.54 & ? \\
\hline $\begin{array}{l}\text { Чеглок } \\
\text { (Falco subbuteo) }\end{array}$ & 23.83 & 57 & 50 & 52.5 & 44.69 & 53.18 & 31.63 & 16.38 & 1.88 & 0.78 & 54 \\
\hline $\begin{array}{l}\text { Пустельга } \\
\text { обыкновенная } \\
\text { (Falco tinnunculus) }\end{array}$ & 22 & 44 & & & 29.62 & 34.82 & 29.84 & 16.27 & 1.35 & 0.67 & ? \\
\hline $\begin{array}{l}\text { Ястреб-перепелятник } \\
\text { (Accipiter nisus) }\end{array}$ & 21 & 60 & 50 & 54.25 & 29.06 & 27.37 & 34.55 & 10.76 & 1.38 & 0.48 & 55 \\
\hline
\end{tabular}


Рис. 7. Аистанции вспугивания хищных птиц (FID) и Аистанции от гнёзд $А$ края зоны нарушений, на которых гнёзда бросаются хищными птицами (DD): FID-B Ао птицы на присаце в период выкармливания птенцов, FID-A - $А$ птицы на присаче в период насиживания яиц, FID-BN - $\triangle$ п птицы на гнезде в период выкармливания птенцов, FID-AN - $А$ птицы на гнезце в период насиживания яиц, DD-Av - средние Аистанции.

Fig. 7. Flight initiation distances (FID) and distances from abandoned nests to the edge of the disturbances zones (DD): FID-B - to bird on perch in nestlingrearing period, FID- $A$ - to bird on perch in incubation period, FID-BN - to bird in nest in nestling-rearing period, FID-AN - to bird in nest in incubation period, $D D-A v$-average distances.

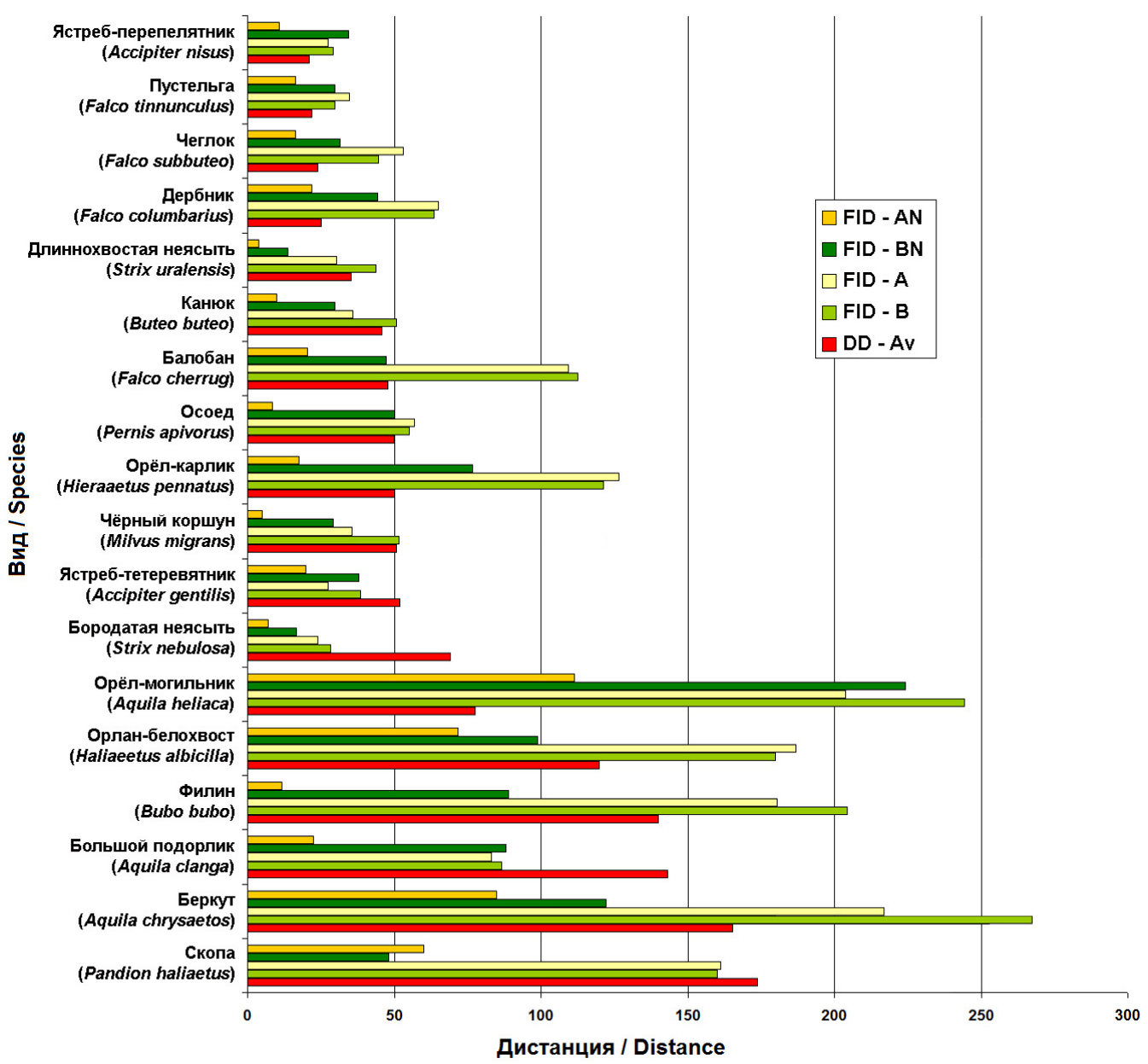

Такое обилие выборочных рубок на гнездовых участках хишных птиц связано с несколькими причинами. Во-первых, после изменения постсоветского лесного законодательства и разрушения системы государственного экологического контроля, у лесопользователей открылась возможность рубить именно выборочными рубками последние сохранившиеся "ресугиумы", бывшие ранее зашитными лесами, гле сохранилось Аостаточное количество гнездяшихся хишников. Во-вторых, многие хишники стараются строить гнёзда на максимацьно труднодоступных территориях островах среди болот, крутых скионах гор, которые легче осваиваются выборочными рубками, нежели Аругими их типами. И, наконец, в-третьих, территория исследований затрагивает преимушественно ^есостепь, с очень мамой плошалью леса, гАе сплошные рубки проводить на большинстве лесных участках попросту невозможно. Тем не менее, очевидным результатом исследования является то, что выборочные рубки мия хишных птиц не менее опасны, чем иные нарушения. Поэтому многие виды дистанцируются от нарушенного выборочными рубками (разреженного) леса дальше, чем от края сплошной рубки или линейного нарушения структуры леса (противопожарные разрывы, АЭП, Аороги и Ар.) (см. табл. 4).

Вне зависимости от типа нарушений, по совокупности наблюдений, был получен видоспецисический материаи по дистанциям от гнёзА $\Delta$ о зон нарушений структуры леса, который, наряду с FID мля разных виАов в разные периоды гнездового сезона, позволяет подойти к научно обоснованной выработке ОЗУА мия охраны пернатых хишников.

В виловых очерках представлены результаты анализа дистанций (FID и DD) по данным настояшего исследования, а также обсуждается их отличие от анамогичных или близких к ним Аистанций, полученных Аля этих же видов Аругими исследователями на Аругих территориях.

\section{Обоснование размеров буферных зон вокруг гнёзА хищных птиц}

Зарубежными исследованиями показано, что в период насиживания киадок у птиц FID = 0,44×AD, но выше в перио выкармиивания птенцов, однако на обоих этапах цикла размножения FID составляет 
Рис. 8. Аистанции от гнёзА хишных птиц $А$ края зоны нарушений: средние Аистанции мяя брошенных гнёзд - DD-M, минимальные Аистанции мия жилых гнёзА - DD-Lm. Сокрашения: BZ-S минимамьный рахиус возможной буферной зоны, BZ-M - среАний рахиус возможной бусерной зоны, BZ1 - BZ4 - предлагаемые градации стандартных размеров буферных $3 \mathrm{OH}$.

Fig. 8. Distances from the raptor nests to the edge of the disturbances zone: average distances for abandoned nests - DD $M$, minimum distances for living nests - $D D$ Lm. Abbreviations: $B Z-S$ - minimum radius of the possible buffer zone, BZ-M - average radius of the possible buffer zone, BZ1-BZ4 - proposed gradation of the standard buffer zone sizes. примерно половину AD и именно AD рекомендуется использовать, как аргумент мля утверждения видоспецисических размеров буферных зон (Whitfield et al., 2008). Т.е. по сути, европейские исследователи предлагают удваивать значение FID мля опрелеления размера буферной зоны вокруг гнезда, в которой Аолжно искиючаться кюбое беспокойство и нарушение естественной среды обитания. Эти параметры иля разных видов отражены в таблице 2 и соответствуют $90 \%$ AD. Американские исследователи рекомендуют рассчитывать минимамьный рахиус буферной зоны, увекичивая в 1,5 раза средние показатели FID (Fox, Madsen, 1997; Livezey et al., 2016).

Результаты нашего исследования показывают, что максимамьные показатели FID (Аля птиц вне гнёзд в период выкармливания вывоАКов) Аля большинства виАОв лежат в диапазоне 30-90 \% от максимаиьных показателей DD (см. табл. 5). Искиючения составляют большой подорлик и бородатая неясыть, мяя которых эта доля составмяет $13,32 \%$ и 22,45 \% соответственно, и орёл-могильник, орёл-карлик, бамобан и мербник, мяя которых FID наоборот выше

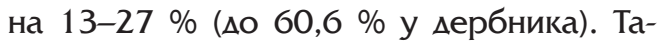
ким образом, вилов, у которых заметная реакция на прямой фактор беспокойства человеком выше, чем толерантность к изменению местообитаний, не так уж и много. Поэтому хорошим обоснованием мля буферных зон могут стать показатеми Аистанций от гнёзА $А$ границы зон нарушений, на которых гнёзда бросаются птицами (DD) и продолжают заниматься (DN). Некой минимамьной Аистанцией, требуюшейся мия сохранения гнездовых участков хишных птиц (не всех $100 \%$ ), можно считать Аистанцию, основанную на разнице между минимальным расстоянием от жилого гнезда $А$ края зоны нарушения (DN-Lm) и максимальным расстоянием от брошенного гнезда $А$ края зоны нарушения (DD-M) (рис. 8, BZ-S в табл. 5). Максимамьная Аистанция, опреАеляющая пределы возможной буферной зоны, вокруг гнезда хишной птицы, Аолжна определяться исходя из максимаиьных значений FID и DD. Оптимамьно, мяя сохранения гнездового участка, бусерная зона вокруг гнезда хишной птицы должна превышать средние значения как FID, так и $\mathrm{DD}$, а также полученный нами показатель ([DN-Lm+DD-M]/2), как минимум в 2 раза. Однако на практике даже это не всегла возможно из-за активного лоббирования природопреобразуюшими компаниями в государственных природоохранных органах интересов, противоположных эсрективной охране природы и хишных птиц.

Несмотря на то, что размеры рекоменАованных бусерных зон мля разных видов

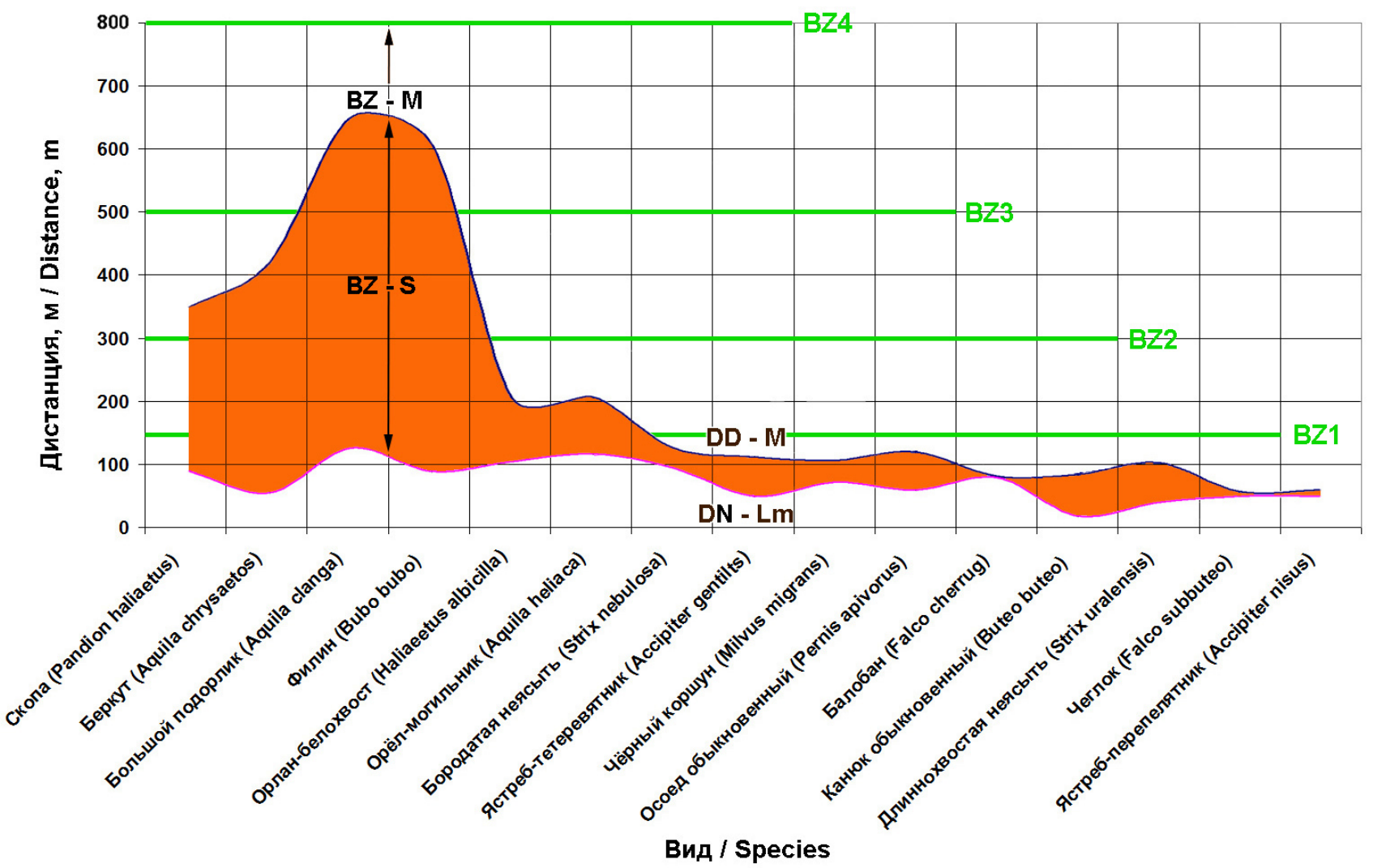




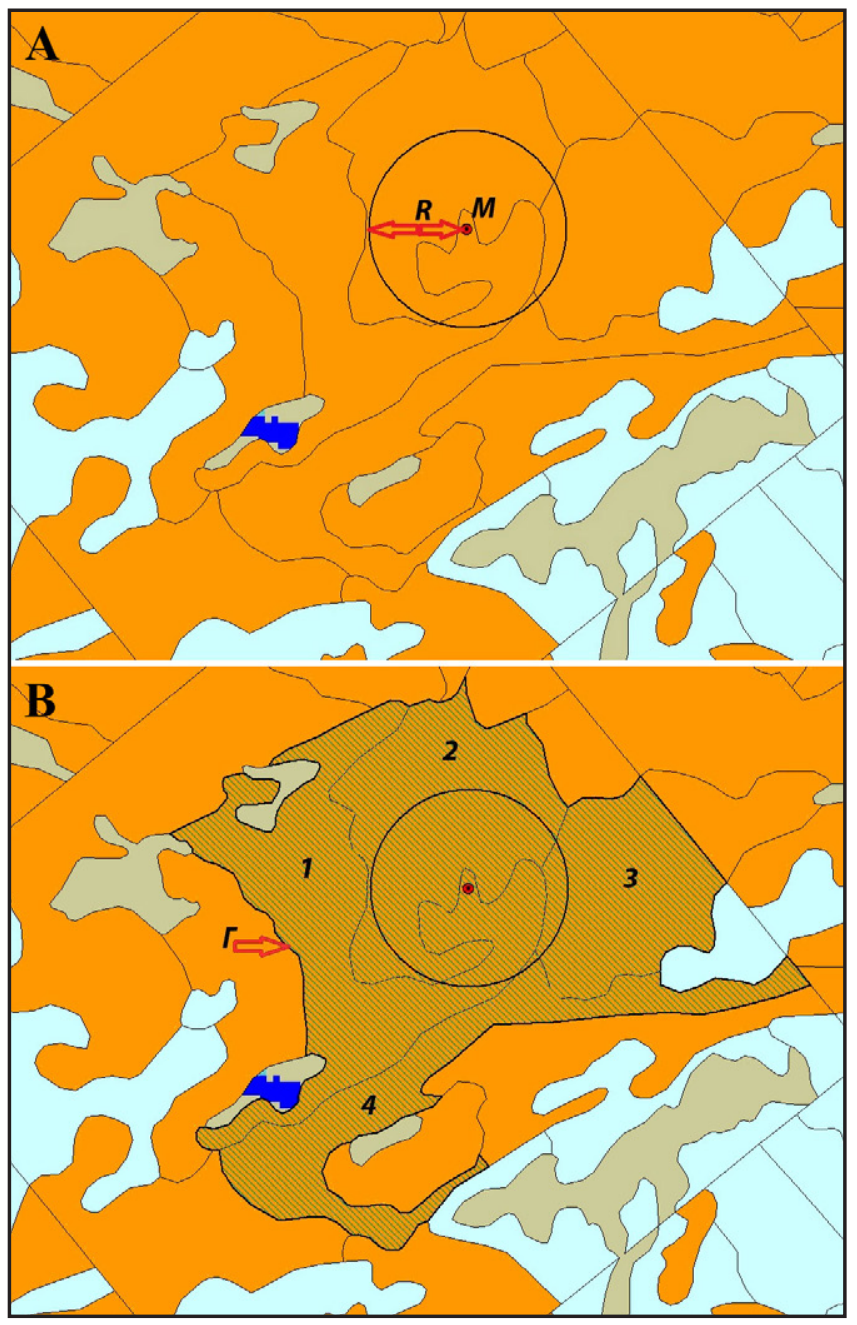

Методика вылеления ОЗУЛ на основе среднего расстояния DD: $A$ - фрагмент плана лесонасаждений с показанием точки-маркера (M) и радиусом (R) в 150 м вокруг неё, В - границы ОЗУА (Г) с лесными вылелами (1-4), входящими в него. Из: Карякин, Николенко, 2015а.

A method for establishing special protected forest areas based on the average DD: A - a fragment of the forest plan with a point-marker $(M)$ and radius $(R)$ of $150 \mathrm{~m}$ around it, $B$ - border of the special protected forest zone $(\Gamma)$ with forest clusters (1-4) included in it. From: Karyakin, Nikolenko, 2015a. уже 10 лет как опубликованы европейскими комегами (см. Ruddock, Whitfield, 2007), по факту, закреплённые законодательно буферные зоны в разных странах Европы не соответствуют прециоженным параметрам, уступая им в размерах в $ы$ ва и более раз. И это наглянно Аемонстрируют размеры бусерных зон, утверждённые на государственном уровне в разных странах Европы, например, мля орлана-белохвоста (Helander, Stjernberg, 2003) или мия целого ряла видов хищных птиц в Венгрии (Pongracz, Horvath, 2010).

Государственные органы по охране природы, сохраняя хишных птиц, вступают в конфликт интересов с лесным бизнесом, часто афффилированным с государственными структурами, и, как правило, идут на уступки в ушерб охране хишных птиц. Наблюдается очевидное стремление к минимизации размеров бусерных зон вокруг гнёзд хишных птиц Аля целей лесного хозяйства, как в России, так и в странах Евросоюза. Поэтому на чаше весов всегла лежат с одной стороны научно-обоснованные размеры буферных зон, оптимальные мия сохранения редких видов, С Аругой - ограничения необоснованно минимизированные лесопромышленным лобби, стремяшимся извлечь большее количество прибыли из арендованного леса. В этих условиях необходимо искать компромисс, который, как правило, приводит к уменьшению размеров буферных зон Ао критических.

Хорошим примером является ситуация с развитием законодательной базы по выделению охраняемых зон вокруг гнёзд редких видов в Алтайском крае. Аия работы в крае была разработана методика вылеления ОЗУА на основе средних показателей DD м^я таких видов, как беркут, орёл-могильник, большой подорлик, орлан-белохвост, балобан, фрилин, бородатая неясыть (Карякин, Николенко, 2015a). Согласно этой методике было прелложено использовать буферы радиусом 80 и 150 м (в зависимости от виАа) вокруг гнёзА, а границы ОЗУЛ проводить по границам вылелов, которые хотя бы частично попахами в эти бусееры (т.е. вымелы не "резаиись" по ралиусу бусера, а ОЗУА вылелялась по внешним границам выделов, которые накрывались буфером, построенным вокруг точки мокации гнезда). Очевидно, что это недостаточно мя гарантированного сохранения гнезАовых участков хишных птиц, но, тем не менее, это был компромисс, в результате которого удалось сохранить рял гнездовых участков хишных птиц в зоне аренды экологически ответственных лесопользователей. В начале 2016 г. бусерные зоны ралиусом 50, 200 и 300 м мия гнёзд размером $\Delta о$ 0,4 м, 0,4-1 м и 1 и более м соответственно были закреплены в лесохозяйственных регламентах большинства лесничеств Алтайского края. В буферных зонах вокруг гнёзд видов, не внесённых в Красные книги РФ или Аитайского края, были запрешены сплошные и выборочные чересполосные рубки, но разрешены Аобровольно-выборочные (Лесохозяйственные регламенты..., 2016). В конце 2016 г. бурерные зоны, вылеляемые в качестве ОЗУЛ, с запретом Аюбых рубок в радиусе 300 м от гнёзд скопы, змееяла (Circaetus gallicus), орла-карлика, большого подорлика, орла-могильника, беркута, балобана, филина, в радиусе 200 м вокруг гнёзд хохиатого осоела, малого перепемятника, бородатой неясыти и в радиусе 100 м вокруг гнёзА воробьиного сычика (Glaucidium passerinum) закреплены в Красной книге Алтайского края (Бах- 
тин, Важов, 2016; Важов, Бахтин, 2016а; 2016b; 2016c; 2016d; 2016е; Важов и мр., 2016; Ирисова, 2016а; 2016b; Плотников, 2016a; 2016b; 2016с; Рыжков, 2016). Эти закреплённые законодательством параметры всё ешё недостаточны мия гарантированного сохранения гнездовых участков таких видов, как скопа, беркут, большой подорлик и фрилин, согласно параметрам FID и DD, полученных м^я того же Аитайского края, но это всё равно уже значительный шаг навстречу охране этих видов.

\section{Рекоменцации по параметрам ОЗУЛ}

ОЗУА в российском Аесном законодательстве вкиючает в себя традиционное понятие бусерной зоны вокруг киючевого элемента биоразнообразия, например гнезда хишной птицы. Как уже отмечалось в начале статьи, каких-либо утвержАённых законодательством фриксированных размеров ОЗУЛ в местах обитания редких виАОв хишных птиц в России не сушествует, а мия обычных видов вылеление ОЗУА не предусмотрено. В Красной книге России только ммя беркута и скопы прописан параметр охранных зон (зон покоя) вокруг гнёзи: мия беркута - $о 0500$ м (Гамушин, 2001), Амя скопы - 200-300 м, причём с ремаркой "Аля продуктивного гнездования скопы в условиях повышенного беспокойства" (Ганусевич, 2001). В ряле регионаиьных Красных книг приводится фриксированный рахиус буферных зон вокруг гнёзА хишных птиц мия целого ряла видов.

Выборочная рубка на гнездовом участке фимина (Алтайский край). Фото Э. Николенко.

Selective felling on the nesting area of the Eagle Owl (Altai Kray). Photo by E. Nikolenko.
Имеется несколько градаций размеров таких зон, которые ориентированы преимушественно на статус и/или размерный киасс вила (см. например, Бахтин, Важов, 2016 и Важов, Бахтин, 2016b). В разных регионах мяя одного и того же вида размер бусерных зон сушественно варьи-

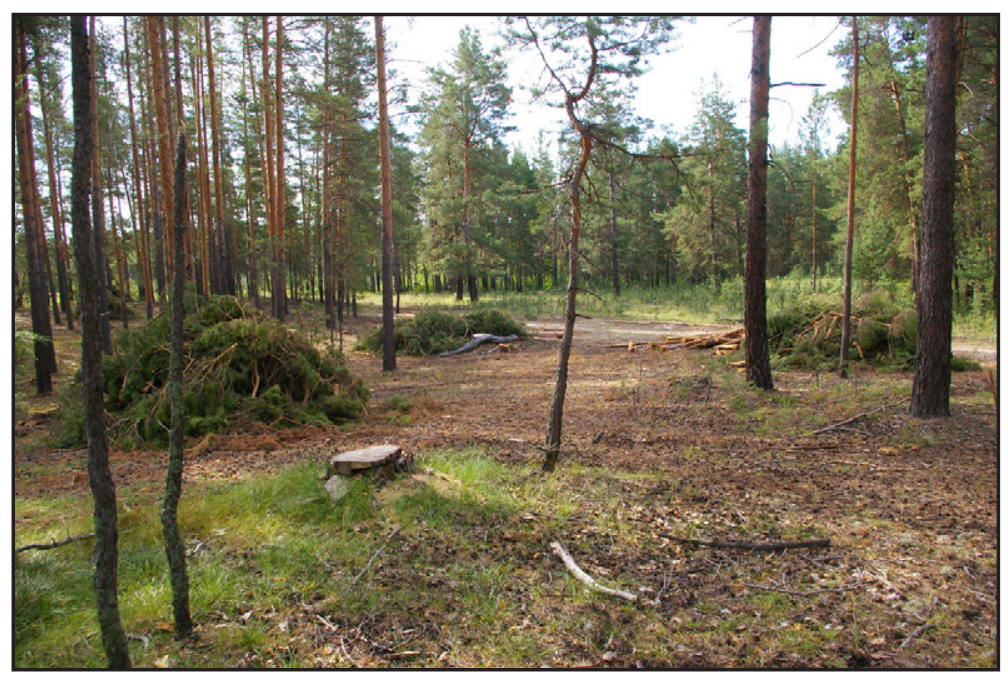

рует: например, мия скопы в Алтайском крае минимамьный рахиус буферной зоны определён в 300 м (Плотников, 2016а), а в Нижегородской области - 500 м (Бакка, 2014а). С одной стороны, это вполне справедливо - закреплённые в Красных книгах параметры буферных зон должны отражать региональную специсиику, так как один и тот же вид по-разному реагирует на одни и те же нарушения и срактор беспокойства в разных частях своего ареала, на что влияет множество причин, вкАючая условия размножения и кормодобычи, уровень браконьерства и пр. (см., например, Ferrer et al., 1990; Galeotti et al., 2000). С Аругой стороны, при отсутствии какихмибо чётко прописанных норм в лесном законодательстве, лесопользователи стараются оспаривать нормы, прописанные в Красных книгах, особенно в регионаиьных, часто сознательно иля на нарушения или ^оббируя принятие местных законодательных инициатив, противоречаших природоохранному законодательству (см. пример Архангельской области во Введении).

Аля искиючения различных спекуляций на тему Аопустимых Аистанций отвода ^еса в рубку близ гнёзд хишных птиц, необходимы какие-то стабильные параметры бусрерных зон, закреплённые в лесном законодательстве, которые могли бы применяться лесопользователями, в том числе и на территориях, Аля которых отсутствуют Аанные по местоположению гнёзд (при неАостаточной исследованности территории).

С целью стандартизации параметров буферных зон (в том числе мия целей созАания ОЗУЛ), вне зависимости от виАа птицы - хозяина гнезда, можно предможить 3 категории размера гнёзд, которые лесопользователи могут обнаружить при плановых осмотрах лесонасаждений и отводе лесосек.

Эти категории уже отражены в ряле лесохозяйственных регламентов лесничеств России, озвучены в ряде методических рекомендаций (Ильина и др., 2009; Марковский, Ильина, 2010; 2014) и учитываются позицией Российской сети изучения и охраны пернатых хишников по вопросу сохранения биоразнообразия на лесных КОТР в ходе лесохозяйственной Аеятельности (см. стр. 62-67):

- мелкое гнезАо - диаметром до 0,4 м радиус бусрера 150 м (BZ1 на рис. 8);

- среднее гнезАо - диаметр от 0,4 Ао 1 м ралиус бусрера 300 м (BZ2 на рис. 8);

- крупное гнезАо - диаметр 1 м и более - рахиус бусера 500 м (BZ3 на рис. 8). 
При проведении орнитологического обследования и установлении видовой принамлежности гнезда мия беркута и большого подорлика, или при установлении гнездования филина, радиус бусера Аолжен быть увеличен $А$ о 800 м (BZ4 на рис. 8).

Поскольку Аокументом, определяюшим охрану редких видов в регионе, является Красная книга субъекта РФ, в ней обязательно Аолжны быть прописаны параметры вылеления буферных зон мия кажАого вида, с учётом региональной специсиики, а также указано, что в буферных зонах запрешены все вилы рубок.

\section{Видовые очерки \\ Скопа (Pandion haliaetus)}

B различных популяциях скопы спектр реакций на человека Аостаточно широк, на одних территориях скопа ведёт себя как типичный урбособ, на Аругих испытывает скионность к синантропизации, гнездясь в зоне застройки на окраинах населённых пунктов и/или на искусственных сооружениях человека (Swenson, 1979; Levenson, Koplin, 1984; Poole, 1989a; Meyburg et al., 1995; Saurola, 1997; Toschik et al., 2006; Schmidt-Rothmund et al., 2014; Bierregaard et al., 2016). В России большинство скоп гнездится в лесной зоне вАами от человеческого жилья и расширения зоны обитания вида за счёт роста толерантных к фактору беспокойства особей в попумяциях практически не происходит. Так, например, в окрестностях Аарвинского заповедника, в котором уже более 30 лет сохраняется крупная гнездовая группировка скопы (Бабушкин, Кузнецов, 2013), за восьмилетний период исследований была засиксирована всего одна попытка



гнездования скоп на гнездовой платсрорме в 3 км от крупного города (Бабушкин, Кузнецов, 2008). Ааже при освоении мия

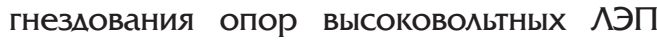
(Бакка и др., 2008; Аинкевич, 2011 ; Карякин и др., 2017), скопа Аистанцируется от мест с постоянным присутствием мюдей. Эти наблюдения кишний раз подтверждают озвученное ранее мнение, что реакция скоп на фрактор беспокойства и антропогенные нарушения местообитаний, сильно зависит от степени привыкания конкретных индивидуумов (D’Eon, Watt, 1994 из: Naylor, Watt, 2004).

По нашим Аанным максимальные показатели FID отмечены м^я птиц вне гнёзА в период насиживания яиц - $(n=29)$ 161,21 99,71 (40-400 м), в то время как в период выкармливания птенцов они были несколько меньше - $(n=25) 160,20 \pm 85,52$ (55-350 м) (рис. 9). Минимаиьная дистанция от гнезда скопы $А$ края зоны нарушений, на которой гнезАо осталось жилым, составляет 90 м (единственное обнаруженное нами жимое гнездо в зоне менее 180 м $А$ края выборочной рубки), при средней дистанции DD, на которой гнёзда оказались брошенными - $(n=9)$ $173,89 \pm 98,23$ м (рис. 9).

Аля 2-х пар, гнездившихся на опорах АЭП в Поволжье (Бакка и Ар., 2008) и в Запанном Саяне (Карякин и нр., 2017), Аистанции вспугивания не отличаиись от обшей массы наблюдений. Птицы, гнезАившиеся на АЭП в Поволжье, спокойно пропускаии туристов, плывуших на байАарках по р. Керженец в 50 м от гнезда, однако покидали гнезАо при попытке остановиться и высадиться на берег напротив гнезда. Аналогичным образом выглялела ситуация со скопами, гнездившимися на ^ЭП в Саяне - они не реагироваии на автотранспорт, Авигаюшийся по трассе в 100 м от гнезАа, но начинами проявлять беспокойство при остановке машины, при этом самец улетаи при попытке приблизится к гнезду на 90 м, а самка покидала гнездо с Аистанции 50 м.

Аля скопы в Великобритании AD в период киалки определена в среднем 329 м, в период выкармливания птенцов - 325 м

Птенцы скопы (Pandion haliaetus) в гнезде. Фото С. Бакки.

Nestlings of the Osprey (Pandion haliaetus) in the nest. Photo by S. Bakka. 

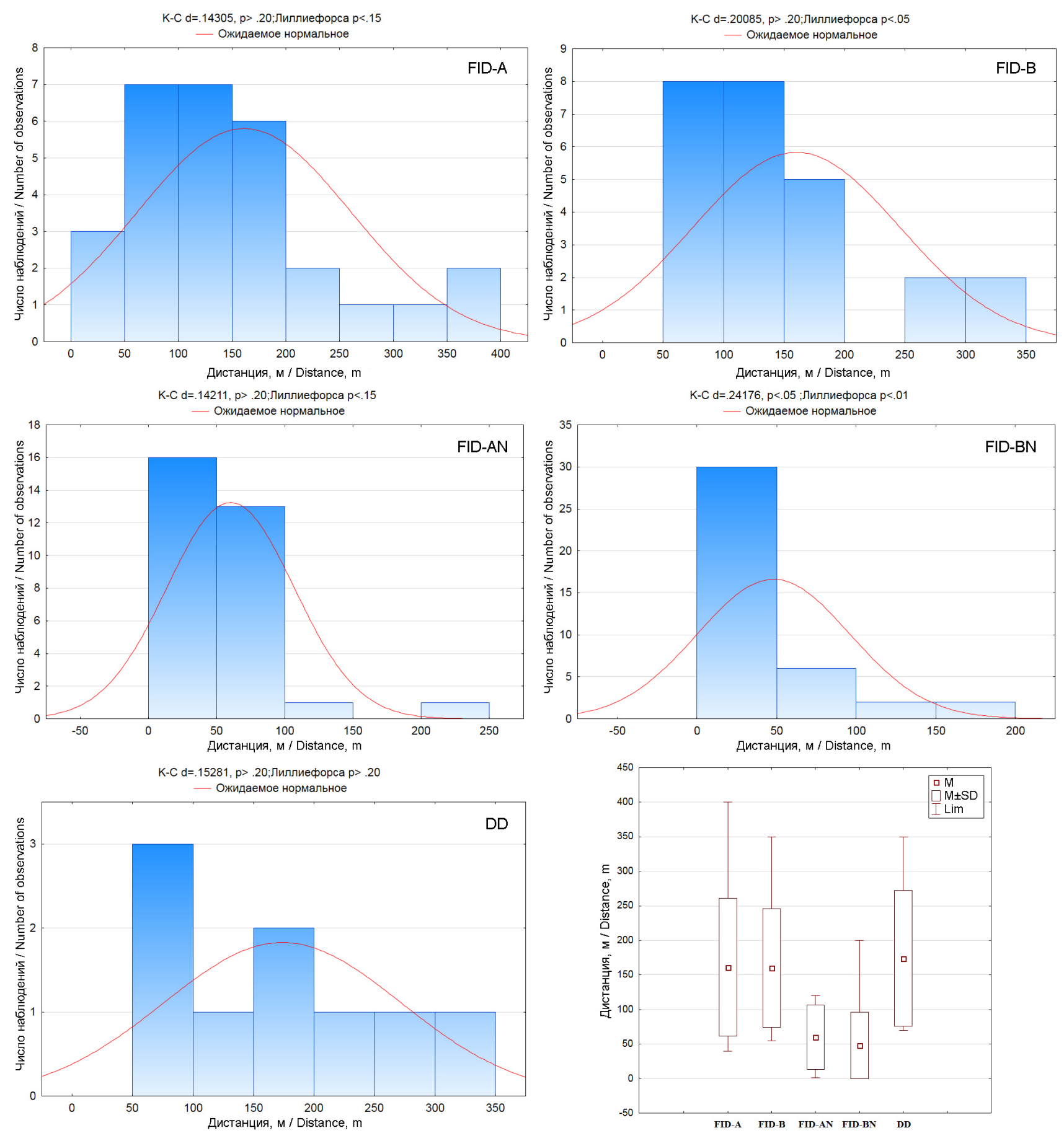

Рис. 9. Аистанции вспугивания (FID) скопы (Pandion haliaetus): FID-A - Ао птицы на присаце в период насиживания яиц, FID-B - $\Delta$ о птицы на присаце в период выкармиивания птенцов, FID-AN - $\Delta$ птицы на гнезде в период насиживания яиц, FID-BN - $\Delta$ о птицы на гнезде в период выкармиивания птенцов; DD -дистанции от гнёзд скопы, Ао края зоны нарушений, на которых гнёзда бросаются птицами.

Fig. 9. Flight initiation distances (FID) for the Osprey (Pandion haliaetus): FID-A - for a bird on a perch during incubation period, FID-B - for a bird on perch during the nestling-rearing period, FID-AN - for a bird in a nest during incubation period, FID-BN - for a bird in a nest during the nestling-rearing period; $D D$ - distances from abandoned nests of the Osprey to the edge of the disturbances zones.

(медиана во все периоды 225 м), FID - в период киалки составляет в среднем 225 м (медиана 175 м), в период выкармливания птенцов - 221 м (медиана 225 м); 80-процентный интерваи мия AD - 100-750 м, Аля FID в период насиживания киахок 50-750 м, в период выкармливания птенцов - 50-500 м (Ruddock, Whitfield, 2007).
Аия Флориды (США) имеется инсормация о Аистанциях вспугивания птиц с гнёзА в результате стрельбы из огнестрельного орудия - 49,5 21,8 м (20-159 м) и при проходе мимо гнёзд на моторных лодках

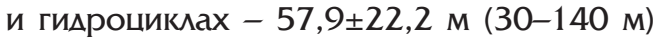
(Rodgers, Schwikert, 2002). На основании этих Аистанций авторы рекомендовами 
150-ти метровую бусрерную зону вокруг гнёзА скопы, в которой бы искАючался Аюбой фактор беспокойства и антропогенные нарушения.

Аия Камисрорнии (США) отмечена более низкая (но не статистически значимая) продуктивность в 34 гнёздах, которые были подвержены беспокойству со стороны человека, связанному с региональной и государственной автомагистрамями, проходяшими близ гнёзА, по сравнению с 33 гнёздами скоп, удаиёнными от автодорог (Levenson, Koplin, 1984). В исследовании 110 гнёзд скоп в Айдахо в 1978-1980 гг. обнаружено, что в гнёздах, расположенных малее 1,5 км от дорог с регулярным Авижением, была более высокая продуктивность, чем в гнёздах, устроенных в пределах 1,5 км от Аорог (средняя Аистанция от гнёзА Ао зоны нарушений составила 770 м) (Van Daele, Van Daele, 1982). На основании этих Аанных были премможены бусерные зоны мия охраны гнёзА скопы радиусом от 400 Ао 1500 м, в среднем 1000 м (Richardson, Miller, 1997).

Некоторые американские орнитологи указывами на то, что явно недостаточно эмпирических Аанных о дистанциях, на которых скопы реагируют на различные нарушения, особенно заметен недостаток систематических исследований по ответам скопы на нарушения, связанные с

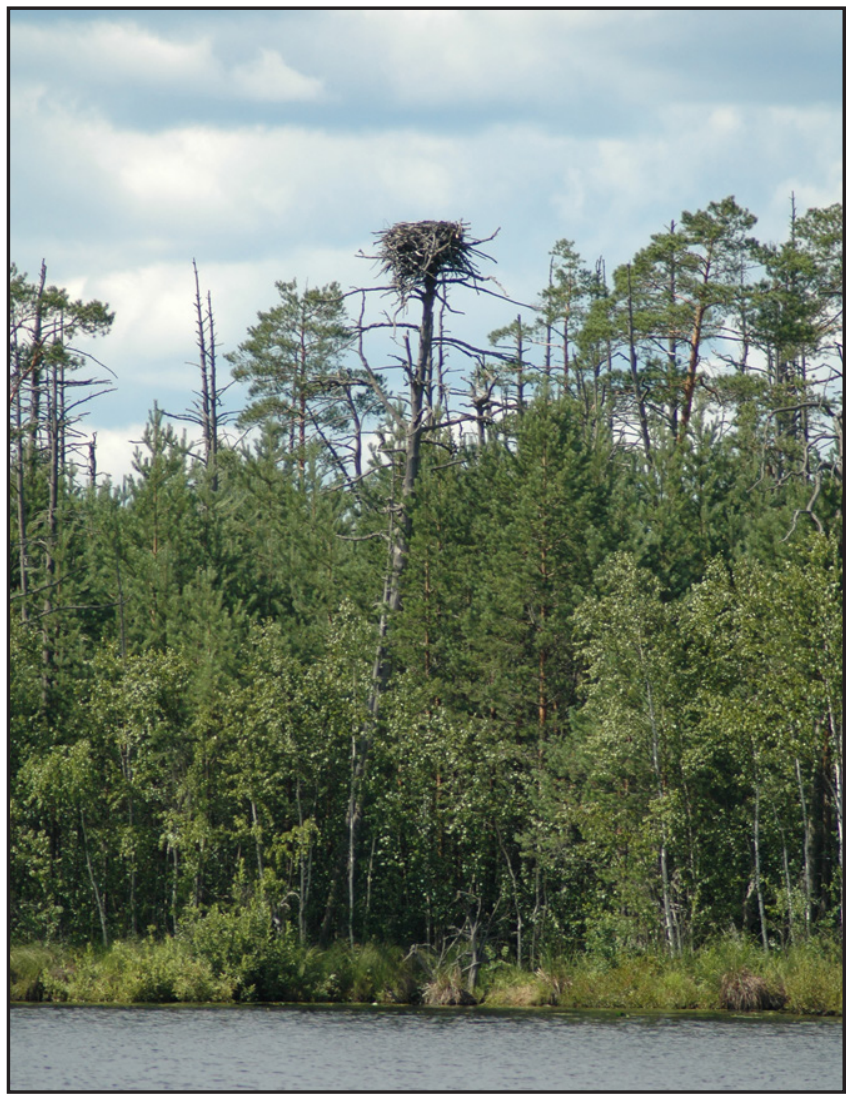

лесохозяйственными операциями (Poole, 1989b; Ewins, 1997). Тем не менее, это не препятствовамо утверждению параметров бурерных зон вокруг гнёзд скопы, ограничиваюших меятельность человека и лесохозяйственных операций. Ряд рекомендаций по управлению лесохозяйственными мероприятиями в местах обитания скопы в США требовал ограничение мюбой хозяйственной деятельности в пределах 660 футов (200 м) от активного гнезда скопы, и полный запрет на вырубку деревьев в 200 фрутах (60 м) от гнёзА скоп (Westall, 1986). В отАалённых районах кемпинги не Аолжны были находиться в пределах 1100 м от занятых гнёзд скоп, а пешеходные тропы в пределах 300 футов (90 м) от гнездовых деревьев (Levenson, 1979). В ряле штатов, гле скопа редка, ралиус буферных зон, утверждённых государственными органами, варьирует от 1/4 Ао 1/2 мили (от 400 АО 800 м) (Cline, 1990; Romin, Muck, 2002; Klute, 2008), но, учитывая продолжаюшееся восстановление численности скопы в США и её синантропизацию, такие размеры бусерных зон считаются некоторыми исследователями излишними (Bierregaard et al., 2016).

Рекомендации по буферным зонам мия скопы, которые в настояшее время используются в бореальной части Канады, написаны в 1983 г. (Penak, 1983). Эти peкомендации требуют создания бусерных зон вокруг кажАого активного (занятого)

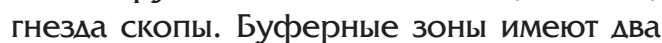
уровня, мля каждого из которых назначены ограничения. Буферная зона - «абсомютная зона" - радиусом 200 м от гнезда запрешает любую лесохозяйственную деятельность в течение всего года; зона в 201800 м от гнезда запрешает строительство и сплошные рубки в любое время года, но разрешает выборочные рубки и лесопосалки вне сезона размножения - с 15 апреля по 1 сентября (Naylor, Watt, 2004; OMNR, 2010). Рекомендации по буферным зонам мяя скопы, используемые в настоящее время в лесах на территории Великих озёр и реки Святого Ааврентия, предусматривают Авухуровневые бусрерные зоны вокруг всех гнёзд скопы, которые были заняты в

Гнездо скопы на усохшей сосне на берегу озера (Нижегородская область). Фото И. Карякина.

Nest of the Osprey on the dry pine tree on the shore of the lake (Nizhniy Novgorod region).

Photo by I. Karyakin. 


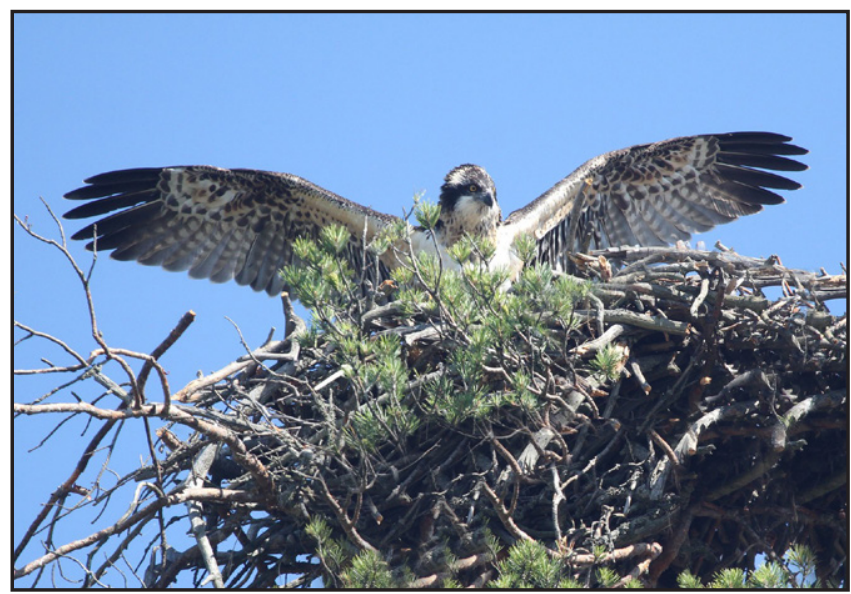

течение последних 5 лет: в 150-метровой зоне запрешается любая месохозяйственная деятельность в течение всего года; в зоне, ралиусом от 151 Ао 300 м от гнезда, запрешены рубки в период размножения (с 1 марта по 31 июля), а вне сезона размножения имеют некоторые ограничения (Naylor, 1994; OMNR, 2010). Стоит отметить, что провеАённая в 2001 г. проверка 150 скопиных гнёзд в районе Великих Озёр не выявили негативного влияния рубок, ведушихся за пределами установленных буферных зон, на занятость или продуктивность гнёзА скопы (Naylor et al., 2003).

В Великобритании мля скопы преможен размер бусерных зон вокруг гнёз 350 1000 м (Currie, Elliott, 1997) и 500-800 м (Petty, 1998). Аия Урамьского региона России прециагалось ограничивать хозяйственную деятельность, вплоть $А$ полного её запрета, на гнездовом участке скопы в радиусе от 500 м до 1 км от гнезда, а дия гнезАовых участков, локализованных в центре какого-либо естественно ограниченного от основного ландшаста биотопа большой протяжённости (островной бор, болото с гривами), было рекомендовано брать под полную охрану весь территориально единый гнезАовой биотоп (Карякин, 1998).

В Красной книге России рекомендуемый размер "зон покоя" Аля скопы - 200300 м (Ганусевич, 2001), в Красной книге Алтайского края - 300 м (Плотников, 2016а), в Красной книге Нижегородской области - 500 м (Бакка, 2014а).

Согласно нашим исследованиям, обоснованный рахиус бусерной зоны вокруг гнезда скопы Аолжен быть не менее 220 м (табл. 5), в оптимацьном варианте - 440 м, однако мия стандартизации размеров буферных зон мля видов, внесённых в Красную книгу РФ и имеюших крупные гнёзда (1 м и более), необходимо придерживаться ралиуса 500 м.
Скопа на гнезце на вершине сосны (Нижегородская область). Фото А. Аевашкина.

Osprey on the nest at the top of a pine tree (Nizhniy Novgorod region). Photo by A. Levashkin.

\section{Орлан-белохвост (Haliaeetus albicilla)}

Всего 3,5 десятилетия назал В.М. Галушин (1982) отнёс орлана-белохвоста к группе антропособов, которые нетерпимы к любым формам беспокойства со стороны человека и слабо способны алаптироваться к антропогенным условиям. За эти годы орлан совершил колоссальный "рывок" в освоении нарушенных человеком территорий на большей части Европы - в большинстве европейских стран он либо восстановил свою численность, либо увеличил $А$ показателей, близких к тем, которые были $А$ краха его популяций в середине XX столетия (Hauff, 2003; Неlander, 2003; Lipsbergs, Bergmanis, 2003; Mizera, 2003; Stjernberg et al., 2009; Herrmann et al., 2011; Ham, 2017; Probst, Pichler, 2017). Этот процесс не обошёл стороной Украину, Беларусь и Россию, гАе восстановление численности орлана было отмечено уже в конце 90-х гг. XX столетия (Гаврилюк, 2004; Гаврилюк, Гришенко, 2008; Витер, 2009; Ивановский, 2012; 2017; Гришанов, Аысанский, 2002; Кузнецов, Бабушкин, 2009; Бакка, Киселёва, 2009; Карякин и нр., 2009b). В Европейской части России на каскацах Волжских водохранилиш срормировамись крупные гнездовые группировки орланов, которые стали служить центрами расселения вида в субоптимальные местообитания (Bekmansurov et al., 2017; Kuznetsov et al., 2017). В процессе расселения по лесостепной зоне орлан стал осваивать мля гнездования лесополосы и небольшие колки леса в агроценозах и высоковольтные АЭП (Пестов, 2005; Бекмансуров и мр., 2012; Белик, 2013; Соколов, 2013). ОАнако в лесной зоне, даже в Европе, гле преследование орлана ниже, чем в России, его привыкание к человеку илёт, по-видимому, медменнее. В частности, в Финляндии в течение трёх Аесятилетий с 70-х по 90-е годы не было получено серьёзных $А$ оказательств привыкания орлана к деятельности человека: средние расстояния $А$ населённых пунктов остались сопоставимыми за три Аесятилетия (от 0,2 $\Delta$ о 2,6 км, в среднем 1,2 км), хотя более близкие Аистанции межАу гнёздами орлана и поселениями человека в 90-е 
годы были зарегистрированы, что считается результатом заселения субоптимамьных местообитаний в условиях роста численности (Wallgren, 2003).

На фоне достаточно большого количества исследований по статусу и разным аспектам экологии орлана-белохвоста в Европе, практически отсутствуют публикации по реакциям этого вида на нарушения. По крайней мере, мы смогли их найти только в работе М. Руццока и $\Delta$. Уитсрильа. По результатам анкетирования специамистов этими авторами установлены параметры дистанций беспокойства и вспугивания орланов в Великобритании: AD в течение всего гнездового периода определена в среднем 500 м (медиана 512,5 м), FID - в период киалки составляет в среднем 205 м (медиана 125 м), в период выкармиивания птенцов - 233 м (медиана 225 м); $80 \%$ интерваи мия AD - 150-1000 м, мия FID 50-500 м (Ruddock, Whitfield, 2007).

По нашим Аанным максимаяьные показатели FID отмечены мля орланов вне гнёзА в период насиживания яиц - $(n=56)$ $186,79 \pm 120,96(40-500$ м), в то время как в период выкармиивания птенцов они были несколько меньше - $(n=75)$ $180,0 \pm 112,10$ (40-450 м) (рис. 10). Аистанция вспугивания птиц с гнёзд в период киамки составияа $(n=72) \quad 71,60 \pm 45,10$ (15-250 м), в период выкармливания выводков - $(n=89)$ 98,93 $\pm 69,98$ (10-350 м). Минимамьная Аистанция от гнезда орлана Ао края зоны нарушений, на которой гнезАо осталось жилым, составляет 105 м (всего обнаружено два жилых гнезда в зоне менее 210 м $\Delta$ края выборочной рубки), при средней дистанции DD, на которой гнёзда оказаяись брошенными - $(n=23)$ $119,74 \pm 85,30$ м, от 25 мо 426 м (рис. 10).

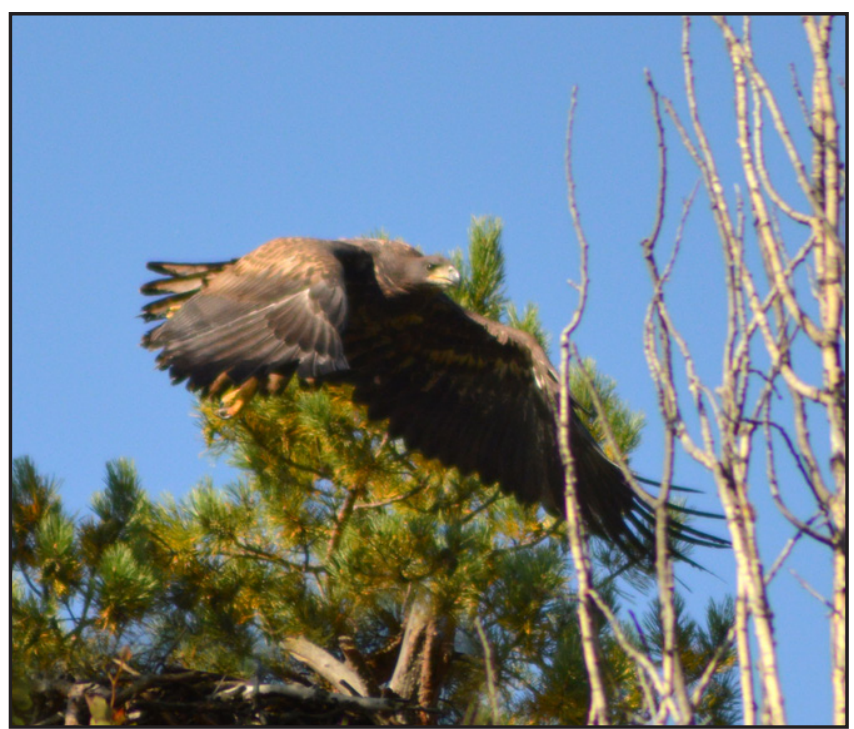

Такое ничтожное количество работ по реакциям орлана-белохвоста на различные антропогенные нарушения и беспокойство резко контрастирует с изученностью в этом плане его ближайшего американского собрата - белоголового орлана (Haliaeetus leucocephalus), который может стать подходяшей моделью мия оценки реакций белохвоста.

По реакциям белоголового орлана на различного рода беспокойство и нарушение местообитаний со стороны человека имеется рял обзоров, в которых обобшается информация, собранная за более чем полвека (см., например, Fraser, Anthony, 2008) с момента предположения возможности нанесения ушерба орланам со стороны хозяйственной и иной деятельности человека (Cunningham, 1960).

Рялом исследований подтверждена меньшая успешность в гнёздах орлана, находяшихся ближе к местам беспокойства со стороны человека, чем в более удалённых. В частности Т.Г. Грабб (Grubb, 1976) обнаружил, что мия гнёзд орланов, устроенных в пределах 0,25 миль (400 м) от зоны нарушений местообитаний человеком, успешные гнёзда были максимамьно Аистанцированы от края зоны нарушений (среднее расстояние составило 130 ярдов - 119 м), нежели те, в которых не было потомства. Средняя успешность размножения орланов была ниже на участках, изменённых в ходе рубок леса или иных природопреобразуюших видов деятельности человека, чем в ненарушенных местообитаниях (Anthony, Isaacs, 1989). В этом же исследовании было обнаружено, что успешность размножения отрицательно коррелировала с близостью к вырубкам, основным лесозаготовительным дорогам и нерегулярным нарушениям. Тремя тематическими исследованиями показано, что рубки в сезон размножения приводили к тому, что орланы покидами гнездовые участки вдоль Чесапикского замива: рубки леса велись на расстоянии от 91 до 366 м от гнёзд орланов и авторы премложили запретить все рубки в сезон размножения в пределах 400 м от гнёзд (Therres et al., 1993).

В исследованиях бюджета времени белоголового орлана показано, что иссле-

Молодой орлан-белохвост, взлетевший с гнезда (Аитайский край). Фото И. Карякина.

A young White-Tailed Eagle flushing from the nest (Altai Kray). Photo by I. Karyakin. 

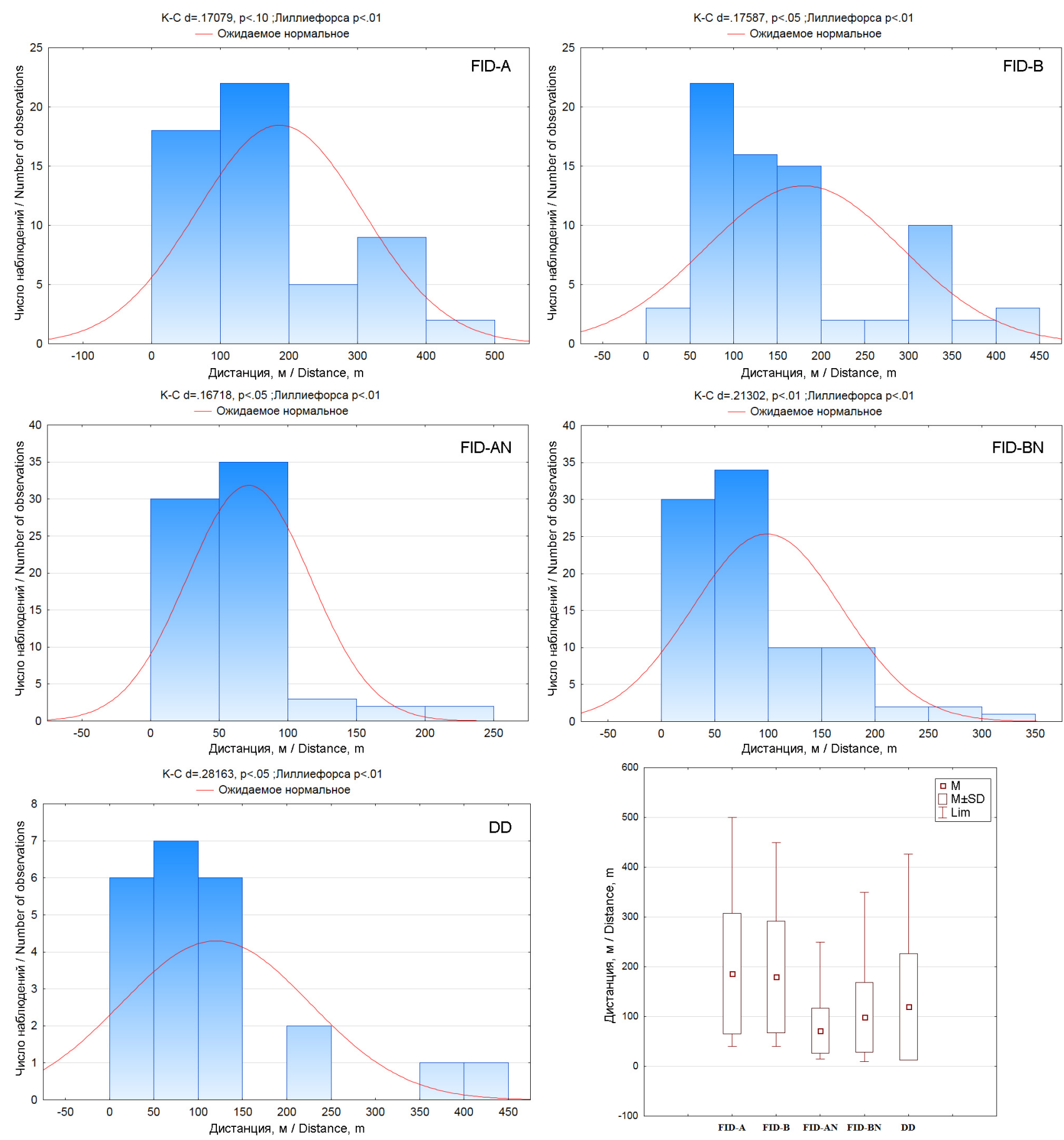

Pис. 10. Аистанции вспугивания (FID) орлана-белохвоста (Haliaeetus albicilla): FID-A - $о$ птицы на присаце в период насиживания яиц, FID-B - АO птицы на присаце в период выкармиивания птенцов, FID-AN - $А$ птицы на гнезде в период насиживания яиц, FID-BN - $о$ птицы на гнезде в период выкармиивания птенцов; DD -дистанции от гнёзд орлана, до края зоны нарушений, на которых гнёзда бросаются птицами.

Fig. 10. Flight initiation distances (FID) for the White-tailed Eagle (Haliaeetus albicilla): FID-A - for a bird on a perch during incubation period, FID-B - for a bird on perch during the nestling-rearing period, FID-AN - for a bird in a nest during incubation period, FID-BN - for a bird in a nest during the nestling-rearing period; $D D$ - distances from abandoned nests of the White-Tailed Eagle to the edge of the disturbances zones.

Аовательский пресс из полевых лагерей в 100 м от гнёзд сушественно снижаи время нахождения взрослых птиц на гнезде, нежели посешения гнёзд из полевых лагерей, устроенных в 500 м от них, что может отрицательно влиять на успех размноже- ния орланов (Steidl, Anthony, 2000).

В одном из исследований в Северной Каролине анализировамись реакции орланов, устроившихся на ночь на присахах, на выстрелы из Аробовика и винтовки исследователь приближался к орланам с 
шагом стрельбы в 200 м, птицы покидаии присады, когАа выстрелы были слеланы на Аистанциях 600 и 400 м, но оставаиись сиАеть при выстрелах, произведённых с Аистанций 800 м и 1 км (Smith, 1988).

Размножаюшиеся орланы наиболее сильно реагировами на беспокойство во время Аобычи пиши и вспугиванись с более млинных Аистанций с присах, нежели из гнёзд, причём пешеходы вызывами наибольшее беспокойство птиц, затем шли модки и Аругие транспортные средства (Grubb, King, 1991). Наибольшее значение имело расстояние $А$ источника беспокойства, причём $64 \%$ реакций регистрировамись на дистанциях менее 215 м, $45 \%$ на Аистанциях 216-583 м и 24\% - на дистанциях более 583 м. В штате Миннесота орманы вспугивамись из гнёзд на дистанциях 57-991 м (в среднем 497 м) пешеходами и наземными транспортными средствами, средняя Аистанция вспугивания одиночным пешеходом составила 476 м (Fraser et al., 1985).

$\triangle$ истанции вспугивания орланов при беспокойстве рыбаками, передвигаюшимися по берегу реки, в разных исследованиях варьировами в диапазоне от 15 Ао 300 м: 15-300 м, в среднем 131 м (Stalmaster, Newman, 1978), 191-246 м, в среднем 270 м (Smith, 1988). Аистанции вспугивания птиц мотоботами варьироваиа от $0 \Delta 0 \Delta 0540$ м: 0-395 м, в среднем 137 м (Smith, 1988), 40-475 м, в среднем 215 м (Buehler et al., 1991), 50-468, в среднем 197 м (McGarlgal et al., 1991), 112-540 м, в среднем 393 м (Wallin, Byrd, 1984). Аистанция вспугивания орланов Аюдьми, сплавляюшимися на каноэ, составила в среднем 178 м (Knight, Knight, 1984).

Изучение зимуюших орланов показало, что Аистанция вспугивания и время, затраченное на возврашение орланов назац на точку вспугивания, варьировами в зависимости от источника беспокойства: после вспугивания орланы улетаяи на расстояние $А$ о 710 м, 410 м и 246 м от пешеходов, рыболовных судов и АодОК с туристами соответственно. Средние дистанции вспугивания птиц с присац варьировами от 111 м (реакция на каякеров) до 201 м (реакция на рыбка, имушего по берегу) (комбинированная средняя Аистанция составила 133 м); Аистанции вспугивания кормяшихся птиц изменялись от 113 Ао 293 м (комбинированная средняя дистанция составила 224 м, минимаиьные мистанции вспугивания также были характерны при беспокойстве птиц Аюдьми, сплавляю- шимися на каяках, а максимаиьные - при беспокойстве пешими рыбаками); время возврашения орланов после беспокойства варьировало от 31 до 241 минуты и было минимальным при беспокойстве АюАьми, проплывавшими мимо на моторных судах, и максимальным при беспокойстве пешеходами (Stalmaster, Kaiser, 1997).

Разные факторы смягчают эсффекты нарушения, например высота расположения гнезда. Так, орланы, гнездяшиеся на высоте более 47 м, вспугивались пешеходами на меньших дистанциях, по сравнению с птицами, гнёзда которых были расположены на более низких деревьях (Watson, Pierce, 1998 из: Ruddock, Whitfield, 2007). В устье р. Колумбии в 1985-86 гг. средние Аистанции вспугивания орланов с присах различной высоты (от 1 Ао 10 м) изменяАись от $146 \pm 21 \quad(n=17) \Delta$ о $251 \pm 24(n=17)$ и были максимальны мля птиц, сидяших на низких присадах; также дистанция вспугивания варьироваяа в течение минимамьной в 6 утра $(153 \pm 31, n=11)$ и максимальной с 6 мо 8 утра $(224 \pm 21$, $n=18$ ) (McGarigal et al., 1991). Несколько авторов также указами, что белоголовые орланы способны терпеть нарушения местообитаний и беспокойство на более коротких расстояниях, если источник беспокойства или нарушения визуамьно экранирован стеной леса или даже узкой полосой деревьев (Andrew, Mosher, 1982; Watson, 2004).

В исследовании влияния лесопользования на белоголовых орланов вблизи Питерсбурга на Аияске в 1967-1969 гг. гнёзда, расположенные на окраине вырубок, оставленные вАоль береговой полосы, оказались очень восприимчивыми к ветровалам. За одну зиму 1968-1969 гг. 20 \% известных гнёзд, оставленных в ходе рубок, были уничтожены штормом (Corr, 1974). Это исследование легло в основу рекомендаций по ограничению лесопользования в бусерных зонах вокруг гнёзА, радиусом 660 рутов (206 м), а также с целью сохранения береговой полосы в качестве гнездовых местообитаний. В попытке минимизировать воздействие на гнёзда орлана на федеральных землях в Юго-Восточной Аияске, Аесная служба США и FWS закиючили Меморандум о Понимании в 1968 г., который требует устанавливать и поццерживать пятиуровневые бусерные зоны вокруг каждого гнездового дерева белоголового орлана и искиючать всю хозяйственную деятельность в первом уровне бусерной зоны (Johnson, 2008). 
Охранные зоны вокруг гнёзд белоголового орлана радиусом от 100 до 1600 м, в которых запрешены рубки и различные нарушения, были рекомендованы мия территории США различными исследователями (Mathison et al., 1977, Fraser et al., 1985, Romin, Muck, 2002; Larsen et al., 2004). Размер предлагаемых зон в ряле исследований варьироваи в зависимости от типа беспокойства орланов Аюдьми: более 120 м - дия пешеходов (Watson, 2004), 543 м мяя пешеходов, 450-850 м - мяя наземного транспорта и 200 м (Grubb, King, 1991), 364 м - мля маломерных судов (Rodgers, Schwikert, 2002), 250-300 м (Stalmaster, Newman, 1978; Grier et al., 1983), 400 м (Stalmaster, Kaiser, 1997), 400-800 м (Anthony, Isaacs, 1989; Richardson, Miller, 1997), 500 м (Fraser, 1983) и 500-600 м (Grubb et al., 1992) - дия любых типов беспокойства.

При разработке планов управления территориями Службой рыбы и Аичи США в 1981 г. было рекомендовано вылеление во-


невых бусерных зон (Larsen et al., 2004):

1. Охранная зона (первичная зона) радиусом не менее 120 м (400 футов) от гнездового дерева, размер и форма которой варьируют в зависимости от условий участка, таких как топограсия, преоблаАаюшие ветры, растительность, а также толерантность орланов к деятельности человека. В районах, где растительность и/или топограсрия не обеспечивают ацекватной скрытости гнезда в пределах 120 м (400 фуутов), Аолжна рассматриваться возможность увеличения размера охранной зоны. В этой зоне сохраняются все деревья и сушествуюшая структура леса. Мероприятия, которые значительно изменяют ландшаст или растительность, такие как руб-

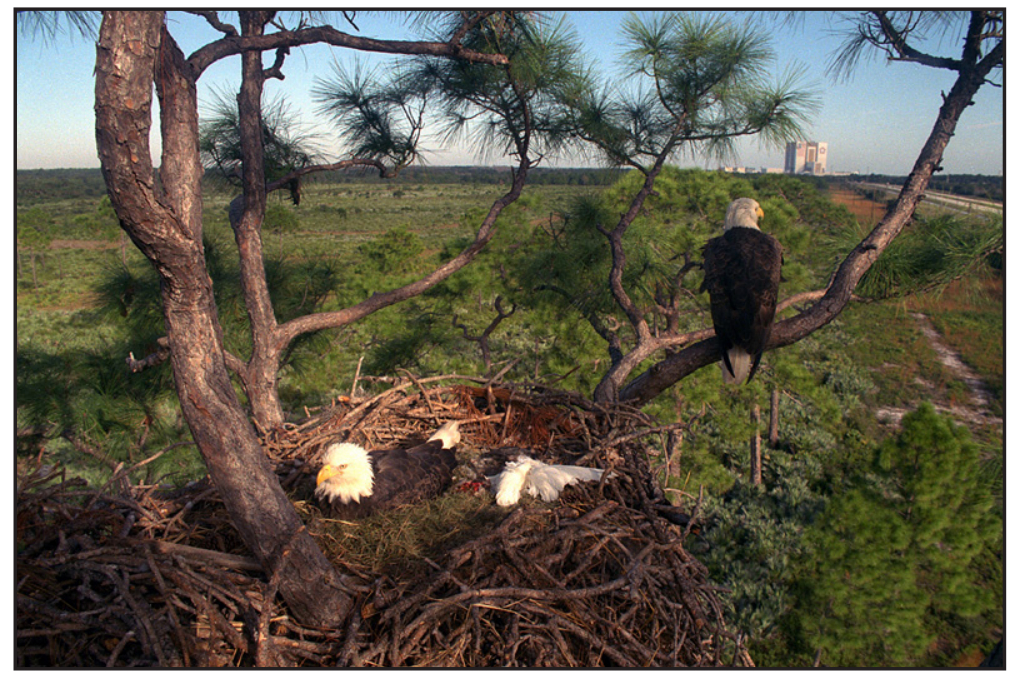

ки леса, строительство зАаний, дорог или миний электропередачи, Аобыча полезных ископаемых и применение химических вешеств, токсичных мля растений или животных, запрешены в этой зоне. В некоторых случаях неразрушаюшие природу, но шумные мероприятия, которые могут мешать орлам, Аолжны быть отложены $\Delta о$ окончания сезона гнездования.

2. Условно-охранная зона (вторичная зона) Аополнительно зашишает места локации гнёзд в ралиусе от 100 Ао 240 м (330800 футов) за пределами охранной зоны. В эту зону Аолжны быть вкиючены альтернативные места расположения гнёзд, присанные деревья и места охоты птиц. В зависимости от растительности, преоблахаюших ветров, топограсии и чувствительности гнездяшихся орланов к деятельности человека, эта зона может быть расширена $\Delta$ о 800 м (2640 сутов) от края охранной зоны. В этой зоне запрешается строительство объектов, создаюших шум и беспокойство, таких как шахты, зоны транспортировки и хранения брёвен, точки по Ароблению горных пород и нестедобываюшие и нестеперерабатываюшие установки. Также в этой зоне запрешено строительство многоквартирного жилья и многоэтажных зАаний, строительство $А$ рог или обустройство троп в пределах видимости с гнезда. Строительные работы (например, Аома, Аороги и линии электропередачи) и лесохозяйственные мероприятия, которые происходят вне поля зрения с гнезда, разрешены, но должны быть отложены $\Delta о$ тех пор, пока молодые орланы не покинут гнездо. Краткосрочное беспокойство, такое как использование сушествуюших Аорог, троп и зАаний, может происходить в условно-охранной зоне круглый гоА.

В то же время в исследовании гнездяшихся орланов в Пьюджет-Саунд (Вашингтон), было слелано предположение, что бусерная зона радиусом 100 м не может обеспечивать Аолгосрочную жизнеспособность и целостность гнезда (Schirato, Parson, 2006). В исследовании на юговостоке А^яски обнаружено, что бело-

Белоголовые орланы (Haliaeetus leucocephalus) на гнезде рялом с Космическим центром Кеннеди в США. Фото предоставлено Б. Аанбаром из NASA.

BaldEagles (Haliaeetus leucocephalus) on the nest near the Kennedy Space Center (USA).

Photo from B. Dunbar / NASA. 


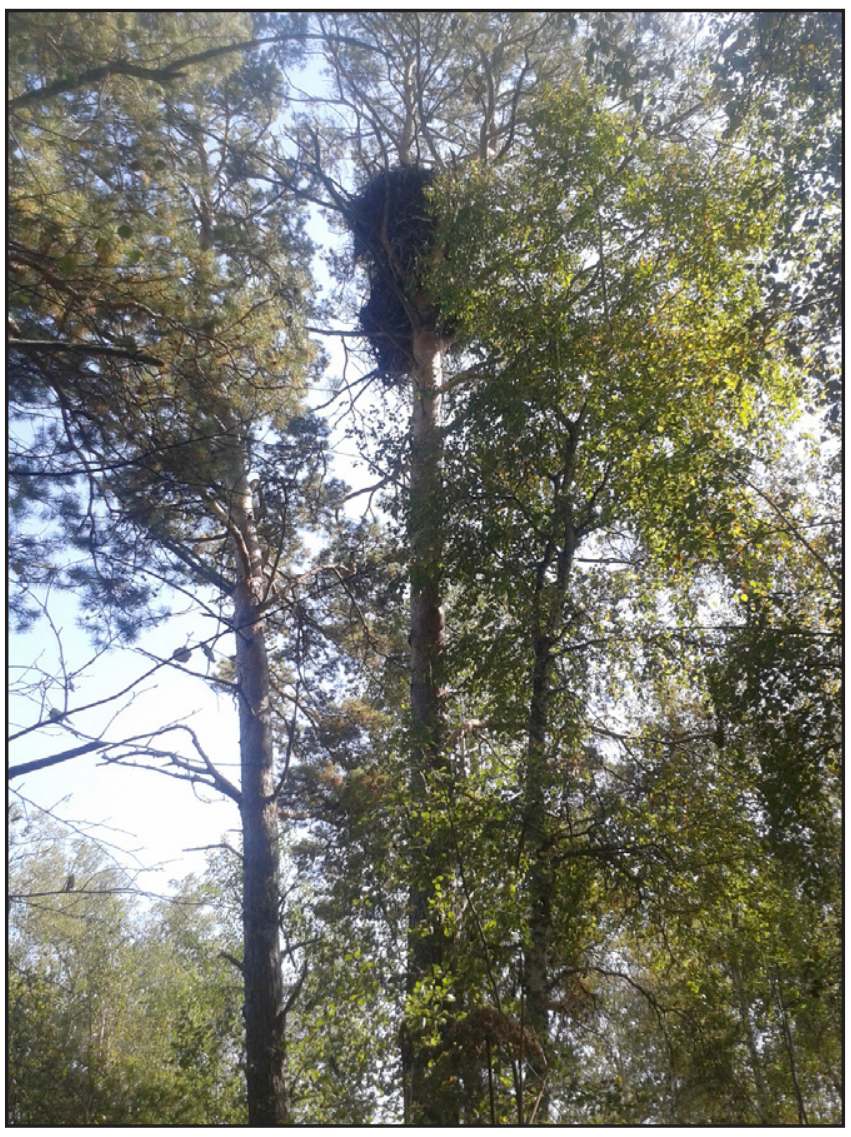

головые орланы, помеченные рахиопередатчиками, использовами территорию, пиошахью около 0,55 км в ширину и 1,25 км вАоль береговой линии, которая оказалась в $А$ ва раза больше буферной зоны. В результате была высказана необходимость расширения размера буферной зоны вокруг гнёзд орланов, как минимум, мяя Юго-Восточной А^яски, чтобы обеспечить намежашую охрану этого вида (Reiser, Ward, 2008).

Современные требования Службы рыбы и Аичи США запрешают рубки круглогодично в радиусе 330 футов (100 м) от гнёзд орлана, а также беспокойство и размичные лесохозяйственные мероприятия и строительство в гнезАовой период в раАиусе 660 фрутов (200 м) от гнёзд (USFWS, 2007). Но некоторые регионаиьные требования опрелеляют больший размер буферных зон, например мия Колорацо - $о$ о 400 м охранная зона, в которой запрешена любая хозяйственная деятельность, и $\Delta о 800$ м - зона сезонных ограничений, в которой возможна ограниченная хозяйственная деятельность только 2 месяца в августе - сентябре (Klute, 2008).

В Канахской провинции Онтарио Министерство природных ресурсов требует вылеление трёхуровневых буферных зон вокруг гнёзд орлана, вне зависимости от за-
Многолетнее гнездо орлана-белохвоста (Аитайский край). Фото И. Карякина.

A long-standing nest of the White-Tailed Eagle (Altai Kray). Photo by I. Karyakin.

нятости этих гнёзА. Самый строгий статус с запретом всех видов рубок круглогодично и беспокойства мюдьми в гнезАовой период (за искиючением научных исследований) имеет первый уровень бусерной зоны в 100 м от гнезда, во втором уровне - в 200-х м от гнезАа также запрешена мюбая хозяйственная деятельность, изменяюшая ландшаст, а именно рубки леса, расчистка земель, дорожное строительство, прокиалка трубопроводов, гинроэнергетика и ^юбое крупное строительство; третий уровень бусерной зоны, радиусом $\Delta$ о 400 м от гнезда имеет меньшие ограничения (запрешены сплошные рубки и строительство, приводяшие к значительным изменениям ландшафта, а также беспокойство в гнезАовой период), и его размер может быть увеличен $А$ 800 м, если топография местности и растительность позволяют получить прямую видимость от гнезда Ао потенциальной зоны деятельности человека на этом расстоянии (Ontario Ministry..., 1987; OMNR, 2010). На примере оз. Эри отмечено, что Ааже в упадочных местообитаниях, сильно освоенных человеком, численность белоголового орлана может быть высокой, что объясняется искиючи-

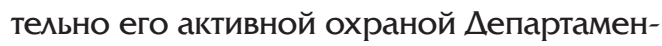
том природных ресурсов штата Огайо и Министерства природных ресурсов Онтарио благодаря созданию 400-метровых охранных зон вокруг гнёзд (в соседних штатах США буферные зоны меньше, и, как следствие, меньше гнездовая плотность орлана) и их активным контролем силами волонтёров (Bowerman et al., 2005).

Старейшие государственные программы по охране гнёзд хищных птиц в Европе берут начало в Швеции и Финляндии в 1924 и 1926 гг. соответственно. В остамьных европейских странах значительная часть государственных инициатив, связанных с созданием зашитных зон вокруг гнёзА редких видов хищных птиц, в том числе и орлана-белохвоста, явилась следствием плохого состояния виАа в 50-60-х гг. ХХ столетия и накопленными свидетельствами негативного влияния деятельности человека (Helander, Stjernberg, 2003). В Чехии государственная программа по охране 
гнёзд стартовала с 1956 г., современные правила запрешают лесохозяйственную Аеятельность в радиусе 300 м от гнёза, в Эстонии - с 1957 г., современный рамиус бусера, в котором запрешены рубки, составляет 100 м на частных землях и 200 м - на государственных. В Польше с 1949 г. введён запрет рубок в радиусе 200 м от гнёзд орлана, а в 200-500-метровой зоне рубки запрешены с 1 января по 31 июля. В Германии в 100 м зоне вокруг гнёзд орлана запрешены все виды рубок, в 100-300-метровой зоне введены ограничения на лесохозяйственные мероприятия и рекреацию в гнездовой период, в 300-500-метровой зоне введён запрет на строительство инсраструктурных объектов. В Литве 200-метровый рахиус зоны вокруг гнёзА, в которой запрешены рубки, установлен в 1999 г. В Аатвии с 2000 г. запрешены все виды рубок в зоне от 400 Ао 800 м вокруг гнёзд орлана, объявленных памятниками природы (разрешена только транспортировка срубленных Аеревьев в период с 1 августа по 1 феврачя при отсутствии Аорог рядом). В Швеции ранее рубки были запрешены в 200-метровой зоне вокруг гнёзд орлана, но с ростом численности этого вида правила были пересмотрены в сторону уменьшения зоны запрета рубок $\Delta$ о 50 м вокруг гнёзА (Helander, Stjernberg, 2003). Аналогичным образом выглялит ситуация в Финляндии, гАе с 2000 г. ралиус зоны вокруг гнезда, в котором запрешена рубка, определяется индивидуально мия каждого гнезда. Хотя ранее, на государственных землях мля охраны орлана-белохвоста были утверждены трёхуровневые бусрерные зоны: в 50 м вокруг гнезда запрешены мюбые виды рубок, в радиусе 500 м от гнезда запрешено беспокойство Аюдьми, но при этом разрешена опрелелённая лесохозяйственная деятельность вне сезона размножения, в 1 км от гнезда запрешено строительство кемпингов и дорог. В основу утверждения вышеприведенных размеров бусерных зон легли исследования по удалённости гнёзд, относительно нарушенных человеком территорий (Stjernberg, 2003): из 97 гнёза, осмотренных с 1960-х по 1980-е

Молодой орлан-белохвост на гнезде (Республика Татарстан). Фото Р. Бекмансурова.

Young White-Tailed Eagle on the nest (Republic of Tatarstan). Photo by R. Bekmansurovn. годы XX столетия, 15 \% располагаиись в ненарушенных участках леса, в которых в рамиусе 200 м от гнёзд отсутствоваии рубки, $17 \%$ были Аоступны на автотранспорте, 32 \% были

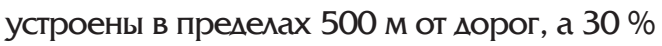
находились в пределах 500 м от ближайших Аач (летних коттеджей).

В Венгрии утвержАённая на государственном уровне зона вокруг гнёзд орлана, в которой запрешены рубки, составляет 100 м (Helander, Stjernberg, 2003), однако это считается недостаточным и премиагается зона 100-200 м, в которой Аолжны быть запрешены мюбые Аолгосрочные нарушения, и зона 200-400 м, в которой ограничивается хозяйственная деятельность с 1 января по 15 июля (Pongracz, Horvath, 2010).

В Великобритании мля орлана-белохвоста предложен размер бусерных зон вокруг гнёза 900-1100 м (Petty, 1998).


лана-белохвоста $\Delta$ о нерегулярных источников беспокойства $(n=24,0,56 \pm 0,11 \mathrm{kм})$, М.Н. Гаврилюк (2002; 2004) премложил создание микрозаказников радиусом 500 м вокруг гнёзд орланов, в которых запрешается проведение лесохозяйственной Аеятельности в период с 1 февраля по 31 июля. Эта рекомендация была закреплена в Красной книге Украины (Гаврилюк, 2009). ОАнако, С.Г. Витер (2015) рекомендует вылелять буферную зону вокруг гнёзд орлана не менее 700 м, мотивируя это Аанными о минимаиьном расстоянии между гнездяшимися парами орлана в Украине, средних размерах гнездового участка и средних размерах участка, который находится под особой охраной птиц в гнездовый период и в пределах которого гнездяшиеся птицы проявляют особое беспокойство по отношению к человеку (окрикивание, пикирование, сопровождение и пр.). В Беларуси известные гнёзда

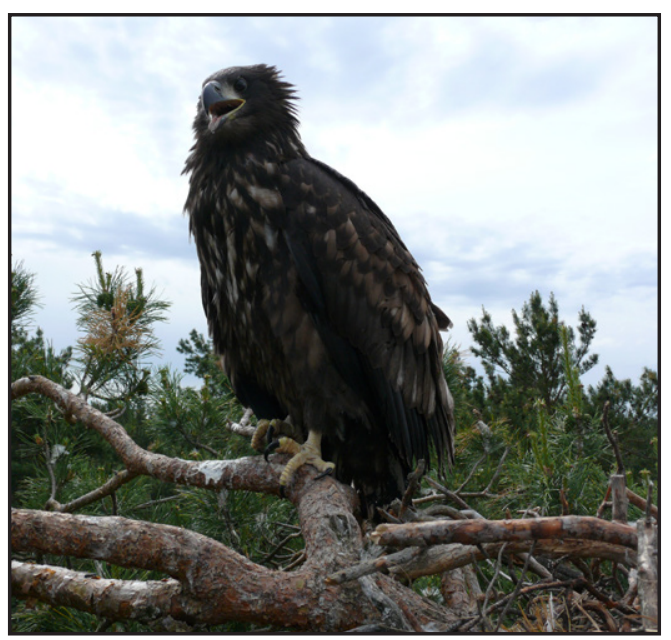


орланов берутся под охрану региональными структурами Минприроды, вокруг них устанавливаются охранные зоны радиусом 250 м (Ивановский, Аомбровский, 2006а).

В России буферные зоны, вылеляемые в качестве ОЗУЛ, с запретом любых рубок в рахиусе 300 м от гнёзд орлана-белохвоста, закреплены в Красной книге Алтайского края (Важов, Бахтин, 2016с). В Красной книге Нижегородской области прописано требование создавать охранные зоны радиусом 500 м вокруг гнёзд орлана-бемохвоста (Бакка, 2014d). В Красной книге Архангельской области закреплена необходимость строгой охраны гнездовых участков орлана и организация вокруг них охранной зоны рахиусом не менее 1 км, гАе искиючаются все виды хозяйственной Аеятельности, а также обеспечивается полный покой в период гнездования (с марта по август) (Рыкова, 2008).

Согласно нашим исследованиям, обоснованный рахиус буферной зоны вокруг гнезда орлана должен быть не менее 155 м (табл. 5), в оптимальном варианте 310 м, однако мия стандартизации размеров бусерных зон мля видов, внесённых в Красную книгу РФ и имеюших крупные гнёзда (1 м и более), необходимо придерживаться радиуса 500 м.

\section{Беркут (Aquila chrysaetos)}

Беркут - широко распространённый на большей части территории северного полушария виА (Аементьев, 1954; Watson, 2011 ). Несмотря на то, что международный статус беркута является благополучным (BirdLife International, 2015), он охраняется на государственном уровне фактически во всех странах Европы, Северной Азии и Северной Америки как редкий виА, численность которого не может быть высокой в силу его био-экологических характеристик (Watson, 1992а; Галушин, 2001; Abuladze, Shergalin, 2002; Kochert, Steenhof, 2002; Березовиков, 2017).

Беркут отнесён к видам, наиболее чувствительным к изменению их местообитаний и даже на многолетних высокопроАуктивных гнездовых участках происходит прекрашение размножения орлов при строительстве поблизости ветропарков, дорог или каких-либо изменениях в землепользовании (Marquiss et al., 1985; Watson, 1992b; Whitfield et al., 2001; Britten, 2001; Walker et al., 2005; Madders, Whitfield, 2006). Тем не менее, $\Delta$ о сих пор нет нацёжных критериев, которые могли бы предсказать, как те или иные измене- ния местообитаний отразятся на занятости гнездовых участков беркутами и их продуктивности (Вуолкер [Walker], 2003) В некоторых популяциях формируются гнездовые группировки, в которых беркуты становятся толерантными к определённой хозяйственной деятельности чемовека и/или фактору беспокойства. Так, с конца 80-х гг. беркуты стами осваивать мяя гнездования АЭП, устроенные поблизости от Аорог в Узбекистане (Митропольский и др., 1987), а с конца 90-х гг. - и в Казахстане (Карякин и Ар., 2011), однако это относится к орлам нелесной зоны. На большей части своего гнездового ареала в лесной зоне беркут мо сих пор остаётся антропосробом, несмотря на аналогичные ацаптации к гнездованию на сооружениях человека. В частности, в равнинных лесах севера Уральского региона, в зоне произрастания среднетаёжных сосновых месов, после их сведения сформироваиись очаги, гАе орлы освоили мия гнездования геодезические вышки и стами устраивать гнёзда практически искиючительно на этих сооружениях человека. В 90-х гг. XX столетия на Верхнекамских болотах из 40 известных гнёзд - 34 находились на вышках и лишь 6 - на деревьях (все на соснах), на тавдинских болотах в Заураиье из 65 гнёзд 63 располагамись на вышках и 2 на соснах. Отмечено, что в связи с новой ориентацией в гнездостроении беркутов изменились и сами гнездовые постройки, которые стали в $90 \%$ случаев представлять небольшие кучки прутиков на досчатых платсрормах вышек. В итоге эти орлы практически утратили способность строить массивные гнёзда, а вышки, построенные в 50-х годах стали гнить и паАать в 90-х гг., что вызвамо сокрашение численности гнездяшихся птиц: за 5 лет прекратили своё размножение 6 регулярно контролировавшихся пар (Карякин, 1989), но беркут при этом не стаи более толерантным к беспокойству со стороны человека и не начаи гнездиться в сохранившихся участках леса вдоль рек, часто посешаемых ^юдьми, и близ населённых пунктов.

Выбор мест гнездования и снижение успешности размножения у шотландских беркутов хорошо коррелируют с Аоступностью мест их гнездования мия человека (например, близость дорог и густота $\Delta$ орожной сети) (Watson, Dennis, 1992). В исследовании в Норвегии расстояния от гнёзА беркутов $А$ Аомов были обычно более 500 м (минимум 250 м) и, в целом, более 1 км Ао автотрасс (Bergo, 1984). В 
ФинлянАии ближайшие к туристическим центрам и местам массового отыыха Аюдей гнездовые участки беркутов располагамись в среднем в 9,9 км, в то время, как ближайшие успешные гнёзда были удалены в среднем на 10,3 км (Kaisanlahti-Jokimaki et al., 2008). Гнездовые участки беркутов в Айлахо (США) были удаиены на 203-701 м от ближайших Аорог и 934-2675 м от человеческого жилья (Steenhof et al., 1983), причём авторы отследили, что гнездовые участки, занятые взрослыми птицами, были удалены даиьше от Аорог и жилья (523 м и 2272 м соответственно), нежели участки, на которых как минимум один из партнёров был полувзрослым (452 м и 1712 м соответственно). Новейшими исследованиями в Айдахо показано, что плотность туристических троп (в км/км²) в пределах 400 м, 1 км и 3 км от 23 гнёзд беркута составила 2,2 $\pm 2,4$ (Аиапазон 0-7,7), 2,2 $\pm 1,8$ (Аиапазон 0,2-8,3) и 2,6 $\pm 1,7$ (Аиапазон 0,7-7,8) км/км², соответственно; средние расстояния от гнёзА $А$ разных объектов туристической инсраструктуры составили: $307 \pm 257$ м $А$ ближайшей туристической

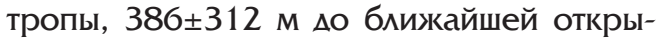
той Аля посешения в сезон размножения

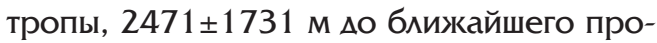
пускного пункта на тропу, 2314 1554 м Ао ближайшего кемпинга, $1829 \pm 1614$ м Ао ближайшего стенда мия стрельбы (Spaul, Heath, 2016). В Ураиьском регионе из 210 гнёзд беркута одно было устроено в 200 м от хутора, на котором постоянно летом проживаяа семья, 6 были удалены на 1 км от населённых пунктов, все остальные 203 гнезда располагамись в 10 и более км от населённых пунктов (Карякин, 1998).

Аоказано, что беспокойство в гнездовой период уменьшало посешаемость взросмыми птицами гнезда и, как следствие, сокрашало количество пиши, поставляемой молодым орлам, когда экспериментальные места мия кемпингов были расположены на расстоянии 400-800 м от гнёзд беркута (Steidl et al., 1993). Также обнаружено, что занятость гнездовых участков беркутов ниже на территориях с более интенсивным движением внедорожников, чем на территориях с меньшим использованием

Гнезцо беркута с птенцом (Нижегородская область). Фото А. Левашкина.

Nest of the Golden Eagle with nestling (Nizhniy Novgorod region). Photo by A. Levashkin. туристами на Ажипах $(\beta=-1.6,85 \% \mathrm{CI}$ -2.8 - -0.8). На занятых беркутами участках использование троп туристами в начаме сезона $(\beta=-1,6,85 \% \mathrm{Cl}:-3,8--0,2)$ и отАых $(\beta=-3,6,85 \% \mathrm{Cl}:-10,7--0,3)$ уменьшаии вероятность успешной откиалки яиц орлами. На территориях, гАе беркуты откиадываяи яйца, пики посешения территорий Ажиперами были связаны с уменьшением выживаемости потомства в гнёздах $(\beta=-0,5,85 \% \mathrm{Cl}:-0,8--0,2)$. Частые подъезды к гнёздам орлов на автотранспорте, быии связаны с уменьшением посешаемости гнёзд взросиыми птицами ( $\beta=-11,9$, 85 \% Cl: -19,2 - -4,5), что является также важным показателем благополучного выживания потомства (Spaul, Heath, 2016).

В работах, связанных с отловом беркутов рахиоуправляемыми лучками, безопасным ммя беркутов расстоянием, на котором они не реагироваяи на исследователей, считалось расстояние в 1-2 км (Marzluff et al., 1997).

Зимуюшие беркуты чаше (100 \% вспугиваний) взлетали при приближении человека (Аистанции вспугивания варьировами от 105 Ао 390 м, составляя в среднем $225 \pm 19$ м, $n=18$ ), но не автотранспорта (19 \% вспугиваний на дистанциях 14-190 м, в среднем $82 \pm 54, n=16$ ) (Holmes et al.

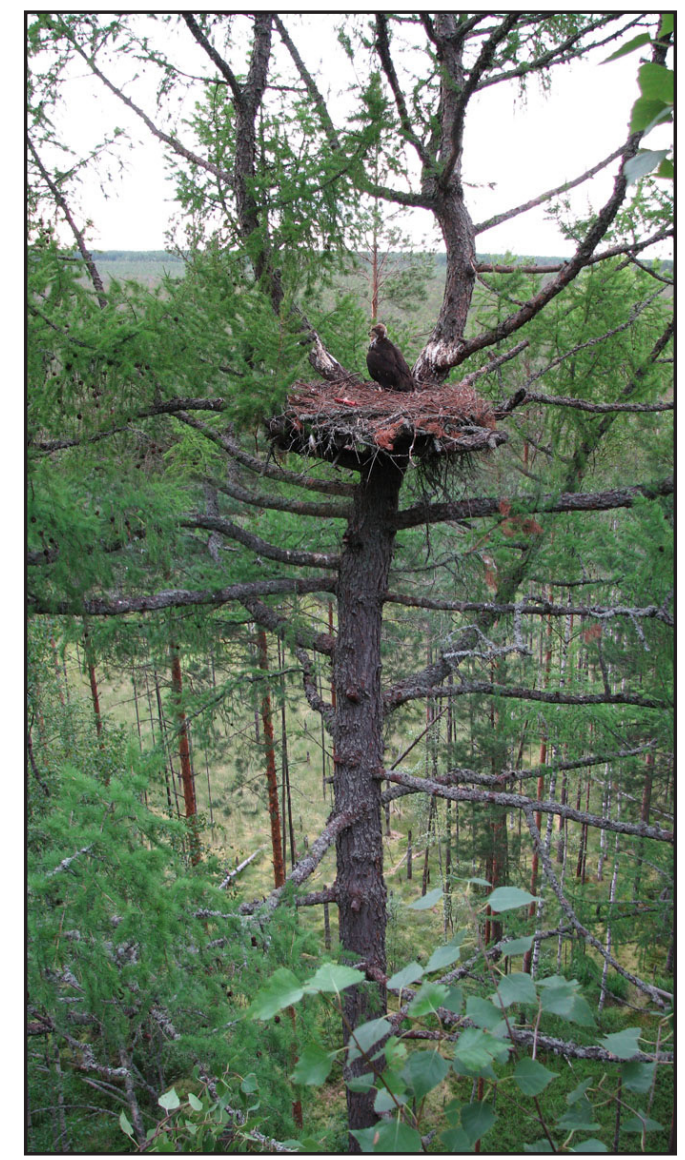




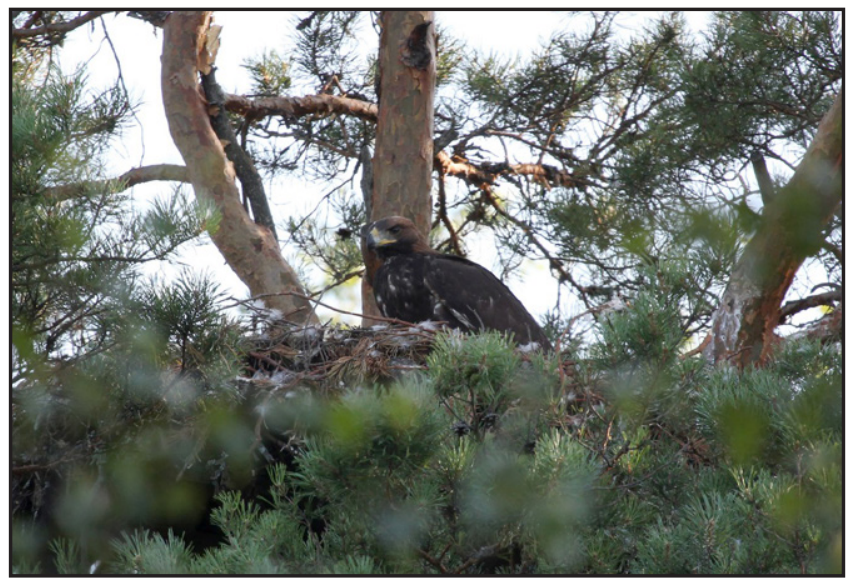

Молодой беркут (Aquila chrysaetos) $\boldsymbol{B}$ гнезде на сосне. Фото А. Левашкина.

Young Golden Eagle (Aquila chrysaetos) on the nest on the pine tree.

Photo by A. Levashkin.
1993). Авторы исследования предположими, что буферная зона 300 м (980 футов) предотвратит вспугивание $90 \%$ орлов. В целом, создание охранных зон на основе 90-95 \% Аистанции вспугивания, считается во многих исследованиях эффеективной стратегией зашиты гнездяшихся хишников, вкАючая беркутов (см. например, Olendorff, Stoddart, 1974; Suter, Joness, 1981; Mersmann, Fraser; 1990).

По данным исследований, проведённых в США, Аистанции вспугивания беркутов с гнёзА одним пешеходом или небольшой группой АюАей составияи в период откахки яиц 15-1073 м (медиана 160, $n=16$ ), в период инкубации яиц - 15-805 м (медиана $100, n=17)$, в период выкарммивания птенцов - 15-1609 м (медиана 333, $n=16$ ); во время работы нескольких человек и машин, создававших шумовой эфрект примерно $90 \Delta \mathrm{Б}$, например, во время бурения или землекопательных работ, беркуты покидаии гнёзда на дистанциях 250-4023 м (медиана 550, $n=16$ ) в период строительства гнёзд, 250-4023 м (медиана 478, $n=16)$ - в период откиаки яиц, 150-1609 м (медиана 402, n=15) - в период инкубации, 100-1609 м (медиана 383, $n=16$ ) - в период выкармливания птенцов; движение внедорожников с частотой раз в час вызывало оставление гнёзд беркутами на дистанциях 91-5632 м (медиана 457 м, $n=15$ ) в период строительства гнезда, 91-2414 м (медиана 457 и 402 м, n=15) - в периол яйцекиалки и насиживания соответственно, 50-2414 м (медиана 200 м, $n=15$ ) - в период выкармиивания птенцов; беркуты охотились результативно на крупную $А$ бычу на Аистанциях 30-3218 м (медиана $400, n=15)$ от большой группы мюАей с крупноразмерным оборудованием (Suter, Jones, 1981). В исследовании 2013 и 2014 гг. на юго-запаце штата Айдахо (США) Аистанции вспугивания беркутов варьироваяи от 1 Ао 1300 м вАами от гнёзд и от 101 Ао 1000 м на гнёздах, причём большинство случаев вспугивания орлов лежало в диапазоне дистанций 100-700 м - вне гнезда и 100-300 м - на гнезде. Орлы в 60 раз чаше взлетали в ответ на беспокойство туристами, которые останавливаяи автомашину, выходили из неё и шли в сторону птицы (11 из 17 случаев) и в 4,5 раза чаше в ответ на приближаюшихся гоншиков на внедорожниках (17 из 121 случаев), чем в ответ на приближение автотранспорта по трассе (7 из 107 случаев). Вспугивание птицы было в 12 раз более вероятным мля орлов, встреченных вАали от гнёзд (23 из 87 случпаев), чем мия орлов в гнёздах (13 из 183 случаев). Орлы взлетали на больших расстояниях в ответ на беспокойство туристами, покидавшими транспорт (в среднем 620 м), чем в ответ на беспокойство гоншиками на внедорожниках (в среднем 525 м) или автотранспортом на трассе (в среднем 318 м). На протяжении всего сезона размножения отмечалось снижение FID. После вспугивания из гнёзА большинство орлов (77 \%) провели более 40 мин. вне гнезда, но у некоторых (23 \%) это время составляло более 90 мин. (Spaul, Heath, 2017).

В России в северных равнинных районах Ураиьского региона практически все птицы при беспокойстве их на гнезде незаметно покидали его зацолго мо появления под ним человека и не появлялись у гнезда $\Delta$ о тех пор, пока фактор беспокойства не исчезал. Птицы, покинувшие гнезАо, мибо прятались в кронах деревьев на Аальних Аистанциях от гнёзА, мибо парили на большой высоте вдаяи от гнезАа, так, что от наблюдателя их скрывали кроны деревьев. В то же время в южных районах Урала беркуты были менее запуганы человеком и при его появлении у гнезда обычно парили нах ним и иногАа даже делали пикеты (Карякин, 1998). Это свидетельствует о разной реакции птиц в разных популяциях на один и тот же тип беспокойства, что зависит как от отношения местного населения к птицам, так и от условий среды обитания.

На^ичие сушественного разброса показателей при оценке ответа беркутов на беспокойство отмечено и в Великобритании. Расхожление мнений в экспертном опросе о беспокойстве мия беркута во время инкубации было больше, чем мия мюбых Аругих видов хищных птиц: 4 респондента озвучили Аистанции вспугивания от 10 Ао 50 м, 1 - $А$ о 1500-2000 м; 
более трети респондентов (8 человек) считали, что вспугивание во время инкубации обычно не происходит $\Delta о$ тех пор, пока наблюдатель не окажется на расстоянии менее 100 м от гнезда, но 4 респондента считами, что вспугивание обычно происходит на расстоянии более 750 м от гнезда. Что касается реакции птицы на беспокойство $\Delta$ о момента вспугивания, то оно фактически не регистрируется Амя беркута и Аругих крупных видов, так как на больших расстояниях его очень трудно, если не невозможно, определить с помошью стандартного полевого оборудования (Ruddock, Whitfield, 2007). В итоге по результатам анкетирования специаиистов в Великобритании установлены следуюшие параметры Аистанций беспокойства и вспугивания беркутов: $\mathrm{AD}$ в периоА инкубации опрелелена в среднем 585 м (медиана 400 м, 80 \% интервац от 100 Ао 1500 м), в период выкармливания птенцов - в среднем 539 м (медиана 625 м, 80 \% интерваи от 150 Ао 1000 м), FID в период киалки определена в среднем 392 м (медиана 225 м, $80 \%$ интервац от 10 оо 1500 м), в период выкармливания птенцов - 447 м (медиана 400 м, 80 \% интервац от 100 Ао 1000 м) (Ruddock, Whitfield, 2007).

По нашим Аанным максимальные показатели FID отмечены мяя беркутов вне гнёзА в период выкармливания птенцов (как правило, это период с 1 мая по 10 июля) - (n=60) 267,5 $\pm 125,48$ (70-600 м, медиана 250 м, мода 200 м), в то время как в период насиживания киаяки (мартапрель) они были несколько меньше - $(n=24)$ 216,88 $\pm 130,67$ (55-500 м, медиана 200 м, мода 200 м) (рис. 11). Аистанция вспугивания птиц С гнёзА в периоА киалки составила $(n=28) 84,82 \pm 62,00$ (0-300 м, медиана 70 м, мода 50 м), в период выкармливания выводков - $(n=52)$

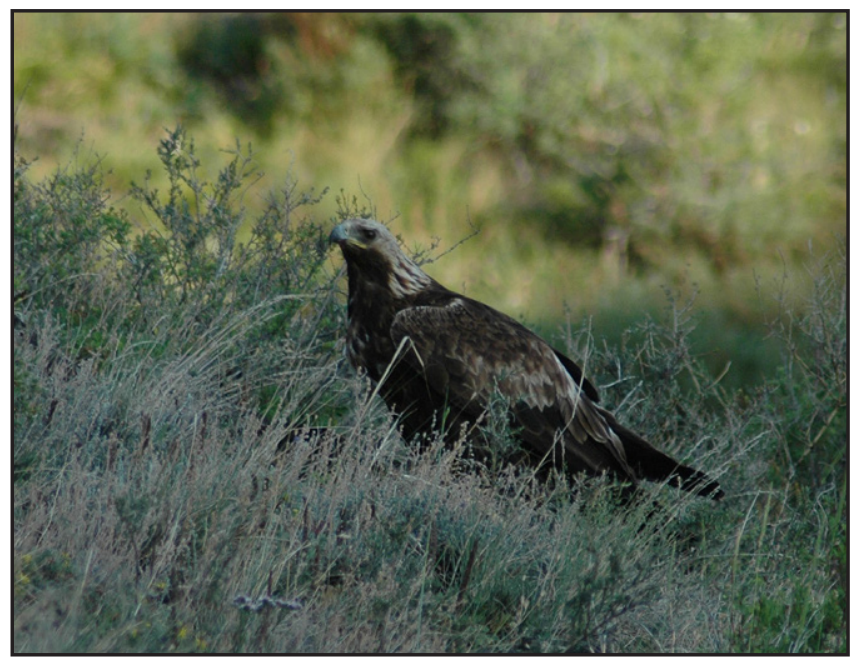

122,02 $\pm 86,38$ (10-350 м, медиана 95 м, мода 50 м). ЕАинственная птица на киадке не взлетела с гнезда в предгорьях Аитая. Также известен фракт затаивания взрослой птицы на гнезде с пуховым птенцом в Нижегородской области (она покинула гнездо только после того, как наблюдатель поднялся на него по стволу дерева), но он не отражён в нашей выборке, так как получен в ходе работы, цеАью которой не было получении инсормации о Аистанциях вспугивания птиц.

В настояшем исследовании минимамьные Аистанции от гнёзд беркута $А$ края зон нарушений, на которых гнёзда остамись жиАыми, составляют 56 и 410 м. В первом случае это была дистанция $А$ строяшейся АЭП, мля чего проведена вырубка леса в 50-метровом коридоре, во втором - выборочная рубка, проведённая весной в том же квартале леса, в котором находилось гнезАо, но с противоположной стороны болота). На дистанциях 440-650 м от края зоны нарушений нам больше неизвестны жилые гнёзда беркута (все остальные локамизованы дамее 650 м от зоны нарушений). Средняя Аистанция DD, на которой гнёзда оказаиись брошенными - $(n=15)$ $165,2 \pm 128,84$ м, от $35 \Delta$ о 420 м (рис. 11). При этом на Аистанциях от 300 Ао 420 м $\Delta$ о края выборочных рубок Аостоверно подтверждено оставление беркутами гнёзд (в большинстве случаев выборочные рубки проводились на тех же гривах леса между болотами, на которых были устроены гнёзма орлов).

Несмотря на представленные выше данные, остаётся не совсем ясным предел терпения беркутов к различным нарушениям на участках. Казамось бы, выборочные рубки на Аистанциях 300-400 м от гнёзд беркута не Аолжны оказывать сушественного влияния на них, но это не так, и, видимо, причина кроется в том, что в зоне исследований взрослые беркуты круглогодично находятся у гнёзд и любое Авижение техники и мюдей на гнездовом участке в любой период года воспринимается птицами как угроза, и они оставляют гнёзда. Примеры из Аругих стран кишь поццерживают это мнение. Так, беркуты бросили гнездовой участок в Аризоне, после того, как $А$ оога была построена в 250 м от гнезда орлов и повторного занятия это-

Взрослый беркут. Фото И. Карякина.

Adult Golden Eagle. Photo by I. Karyakin. 

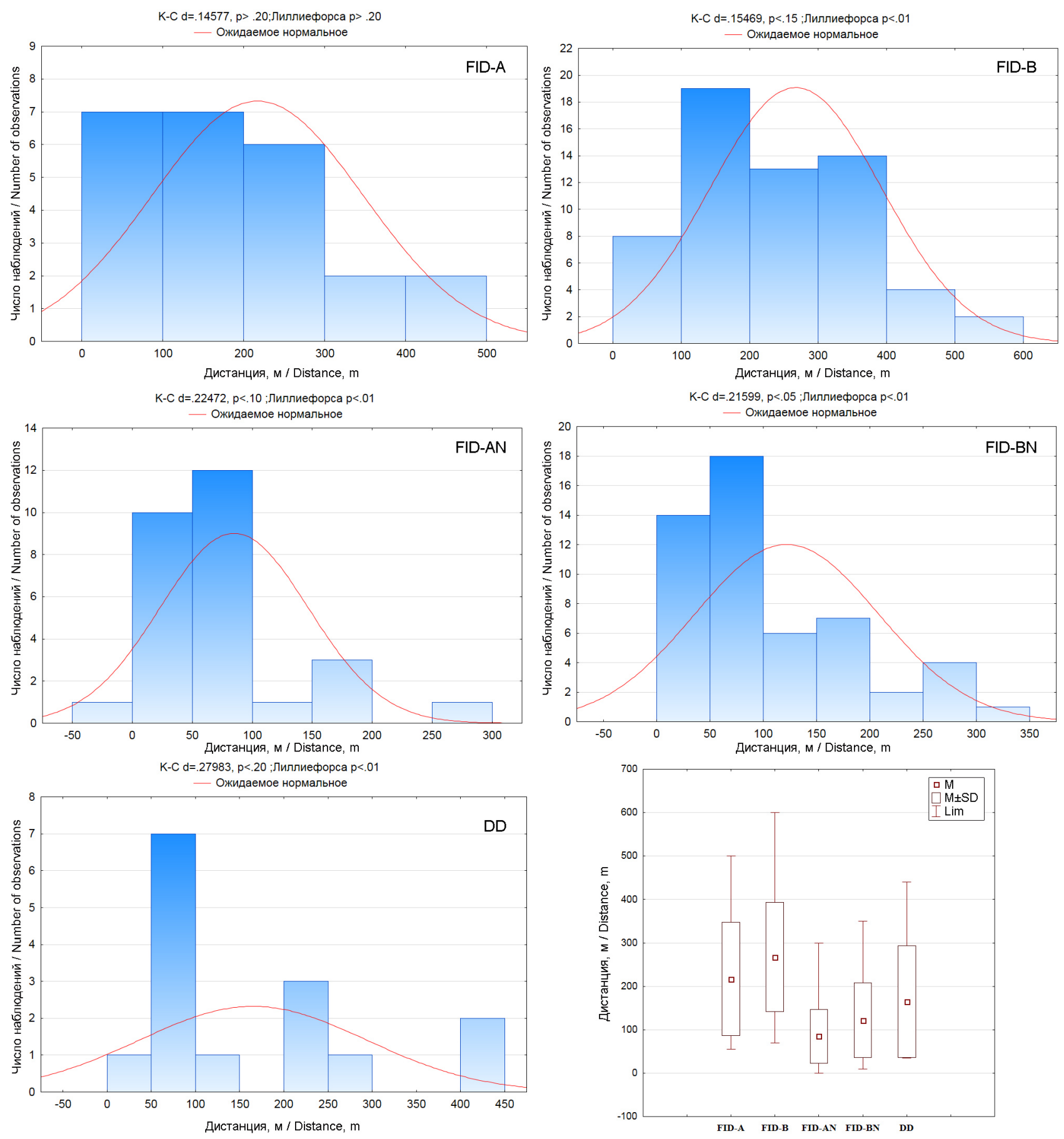

Pис. 11. Аистанции вспугивания (FID) беркута (Aquila chrysaetos): FID-A - $о$ птицы на присахе в период насиживания яиц, FID-B - $\Delta O$ птицы на присаце в период выкармливания птенцов, FID-AN - ) птицы на гнезде в период насиживания яиц, FID-BN - $\Delta O$ птицы на гнезде в период выкармливания птенцов; DD -дистанции от гнёзд беркута, Ао края зоны нарушений, на которых гнёзда бросаются птицами.

Fig. 11. Flight initiation distances (FID) for the Golden Eagle (Aquila chrysaetos): FID-A - for a bird on a perch during incubation period, FID-B - for a bird on perch during the nestling-rearing period, FID-AN - for a bird in a nest during incubation period, FID-BN - for a bird in a nest during the nestling-rearing period; DD - distances from abandoned nests of the Golden Eagle to the edge of the disturbances zones.

го участка в Аальнейшем не последовало (Britten, 2001). Исследования в Швеции показали, что буферная зона с запретом рубок, радиусом 50-300 м вокруг гнёза, недостаточна мяя сохранения беркутов и М. Тьернербергом (Tjernberg, 1986) были рекомендованы бусерные зоны радиусом
500 м (Moss, 2011). Однако и эти параметры сочтены недостаточными мия шотландских орлов, гАе вилимость с гнёзд сушественно выше, чем в Швеции (McGrady et al., 2004). Аия Великобритании в целом рекомендованный радиус бусерных зон мяя беркута варьирует от 750 Ао 1500 м 
(McGrady et al., 1997, Currie, Elliott, 1997; Petty, 1998; McGrady, Petty, 2005).

Региональные требования Службы рыбы и Аичи США мия таких нарушений местообитаний беркутов, как строительство, устройство кемпингов, скамолазание и походы, устанавливают зашитный бусер радиусом 800 м (Rodrick, Milner, 1991; Romin, Muck, 2002), что согласуется с рекомендациями Аругих исследователей (Call, 1979; Richardson, Miller, 1997). В частности, в Колорадо ралиус буферной зоны в которой запрешена хозяйственная деятельность составляет 400 м, а в которой введены сезонные ограничения на беспокойство мюдьми с 15 декабря по 15 июля - 800 м (Klute, 2008). Ранее рекомендоваиись бусерные зоны $\Delta$ о 1,6-3,2 км от гнёзд, запрешающие строительство геотермальных станций и трубопроводов (Jacobson, 1974; Olendorff, Zeedyk, 1978; Suter, Jones, 1981; Richardson, Miller, 1997), но, похоже, они так и остались только на бумаге. Последние исследования в Айлахо, гле размер буферных зон мля беркута меньше, чем в Аругих штатах, показами, что ограничение рекреационной деятельности в буферной зоне радиусом 650 м и 1000 м от гнёзА могло бы сократить вспугивание беркутов с гнёзА на $77 \%$ и $100 \%$, соответственно (Spaul, Heath, 2017), поэтому идеально было бы иметь бусрерные зоны вокруг гнёзд рахиусом 1200 м, запрешаюшие рекреацию в гнездовой период (Spaul, Heath, 2016).

В Финляндии буферная зона вокруг гнёзд беркута устанавливается в радиуce 500-1000 м (Kaisanlahti-Jokimäki et al., 2008), в Австрии - 500 м (Ellmauer, 2005), в Венгрии утвержлённая на государственном уровне зона вокруг гнёзд беркута, в которой запрешены рубки, составляет 100 м и зона 100-300 м, в которой ограничивается хозяйственная деятельность с 1 февраяя по 15 августа (Pongracz, Horvath, 2010). В Красной книге Украины закреплена необходимость создания микрозаказников рациусом 0,5 км вокруг гнёзд орлов (Аомашевський, Годованець, 2009). В Беларуси известные гнёзда беркута взяты под охрану, вокруг них установлены охранные зоны ралиусом 250 м (Ивановский, Аомбровский, 2006b), однако эсрективность этой меры неясна, так как беркут за последние десятилетия фактически выпаи из гнездовой фауны Беларуси (Ивановский, 2014). мия Ураиьского региона России было рекомендовано ограничивать хозяйственную деятельность, вплоть $\Delta$ полного её запре- та, на гнездовом участке пары беркутов в радиусе от 500 м Ао 1 км от гнезда, а если гнездовой участок находится в центре какого-либо естественно ограниченного от основного мандшаста биотопа большой протяжённости (скала, островной бор, бо^ото с гривами), было преможено брать под полную охрану весь территориально единый гнездовой биотоп (Карякин, 1998).

В Красной книге России мяя сохранения основных местообитаний беркута "требуется полное прекрашения рубок лесных "Островов" и "мысов" среди болот и в Аоминах крупных рек; необходимо учреждение охранных зон радиусом $\Delta о 500$ м вокруг известных гнезАовий, искиючаюших беспокойство птиц в сезон размножения" (Галушин, 2001). Буферные зоны, вылеляемые в качестве ОЗУА, с запретом мюбых рубок в ралиусе 300 м от гнёзд беркута закреплены в Красной книге Алтайского края (Важов, Бахтин, 2016b). В Красной книге Нижегородской области прописано требование создавать охранные зоны радиусом 500 м вокруг гнёзд беркута (Бакка, 2014c). В Красной книге Архангельской области закреплена необходимость строгой охраны гнездовых участков беркута и организация вокруг них охранной зоны радиусом не менее 1 км, гАе искиючаются все виды лесопользования, а также обеспечивается полный покой в период гнезАования (с марта по август) (Рыкова, 2008).

Согласно нашим исследованиям, обоснованный радиус бусерной зоны вокруг гнезАа беркута Аолжен быть не менее 238 м (табл. 5), в оптимаиьном варианте - 476 м. Аия стандартизации размеров буферных зон Аля видов, внесённых в Красную книгу РФ и имеюших крупные гнёзда (1 м и более), необходимо придерживаться радиуса 500 м, но при однозначной видовой принамежности гнезАа беркуту, буфер Аолжен быть увеличен $А$ 800 м.

\section{Орёл-могильник (Aquila heliaca)}

С 1994 по 2016 гг. орёл-могильник имеет статус уязвимого вида (VU) в Красном кисте МСОП (BirdLife International, 2017b), но его численность растёт в странах Европы, в Европейской части России и в Казахстане (Карякин и Ар., 2010; Karyakin et al., 2011; Danko et al., 2011; Demerdzhiev et al., 2011 a; 2011 b; Horváth et al., 2011), вил вырабатывает толерантность к определённым видам деятельности человека, нарашивает численность в агроценозах (Horvath, 2009; Карякин, Паженков, 2010;) и нестегазодобываюших 


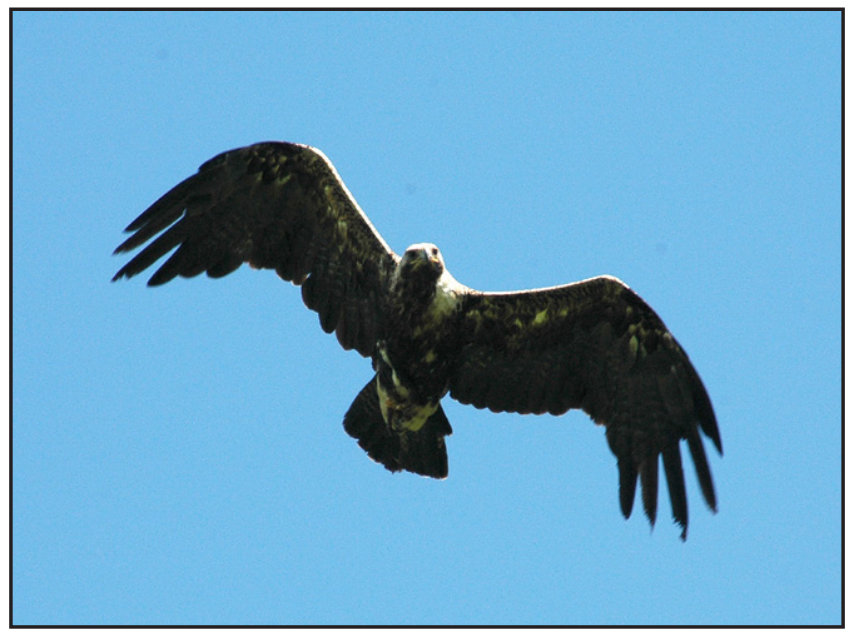

Орёл-могильник (Aquila heliaca). Фото И. Карякина.

Eastern Imperial Eagle (Aquila heliaca). Photo by I. Karyakin. районах, уходя от целого комплекса негативных факторов, осваивает мля гнездования АЭП (Карякин, 2006; 2008b; Карякин, Корепов, 2009; Корепов, 2009; Пшегусов, 2010; Ажамирзоев и мр., 2013; Бекмансуров, 2015).

В настояшее время большая часть популяции могильника сосредоточена в освоенных человеком районах лесостепной зоны Евразии, что накиацывает определённый отпечаток на ответные реакции орла-могильника на беспокойство со стороны человека и нарушения, происходяшие на гнездовых участках орлов этого вида. В Венгрии минимаиьные Аистанции от гнёзд орла-могильника $\Delta о$ населённых пунктов составляли 700 м, $\Delta 0$ автотрасс - 100 м, Ао небольших автодорог с покрытием - 250 м, Ао ЛЭП 10-35 кВ 100 м, Ао АЭП 120-750 кВ - 100 м и некоторые гнёзда располагаиись в лесополосах вАоль железных Аорог (О м); плотность населённых пунктов в занятых орлами квамратах (UTM) составляла 0,018 $\pm 0,05 \mathrm{kM} / \mathrm{kM}^{2}$, в незанятых - 0,071 $\pm 0,126 \mathrm{KM} / \mathrm{KM}^{2}$, плотность автотрасс $-0,063 \pm 0,147$ и 0,084 $\pm 0,177 \mathrm{KM} / \mathrm{KM}^{2}$ соответственно, плотность небольших автодорог с покрытием - 0,124 $\pm 0,190$ и 0,205 $\pm 0,211 \mathrm{kM} / \mathrm{KM}^{2}$ соответственно, плотность железных Аорог - 0,055 $\pm 0,129$ и 0,084 $\pm 0,186 \mathrm{KM} / \mathrm{KM}^{2}$ соответственно, плотность АЭП 10-35 кВ - 0,219 $\pm 0,294$ и $0,427 \pm 0,425 \mathrm{kM} / \mathrm{KM}^{2}$ соответственно, плот-

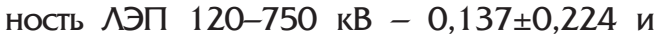
$0,181 \pm 0,315 \mathrm{kM} / \mathrm{KM}^{2}$ соответственно и плотность различных инсрраструктурных объектов (вкиючая вышеприведённые Аороги

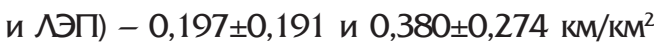
соответственно (Horvath, 2009). В исслеАовании на территории Самарской области Аистанции от гнёзд орла-могильника $\Delta O$ населённых пунктов варьироваяи от 0,1 о 5,0 км, составив в среднем $(n=15)$ $1,62+1,53$ км, Ао феерм - от 0,1 $\mathbf{0 ~ 5 , 0 ~ к м , ~}$ в среднем $1,81+1,52$ км, что соответствует Аиапазону Аистанций мия большей части гнёзА орла-могильника на территории Бугульминско-Белебеевской возвышенности в прелелах Самарской, Оренбургской областей и республик Татарстан и Башкортостан (Карякин, 2010). В Татарстане гнёзда орлов-могильников, освоивших АЭП, были устроены в 200-2900 м от населённых пунктов, 80-1600 м от автотрасс, 250-1500 м от нестенасосных станций, на которых постоянно работают нестяники, 80-670 м от нестекачалок и в целом не отличаиись по $\Delta$ истанциям $\Delta$ о аналогичных объектов от гнёзд на деревьях (Бекмансуров, 2015). В то же время, в предгорьях Алтая в преде^ах Аитайского края отмечено тяготение орла-могильника на гнездовании к менее населённым мюдьми районам, так же как у беркута (Важков, 2012).

Испанский орёл-могильник (Aquila adalberti), гнездяшийся в сходных условиях, показывает анамогичные реакции на фрактор беспокойства. Наиболее частая реакция птиц отмечена на охотников и туристов, в то время как Аругие пешеходы и транспортные средства с меньшей вероятностью вызывали ответ орлов на беспокойство. Могильники также проявляли большее беспокойство на более крупные группы Аюдей, особенно птицы на более открытых и мегко видимых гнёздах. Аальность,

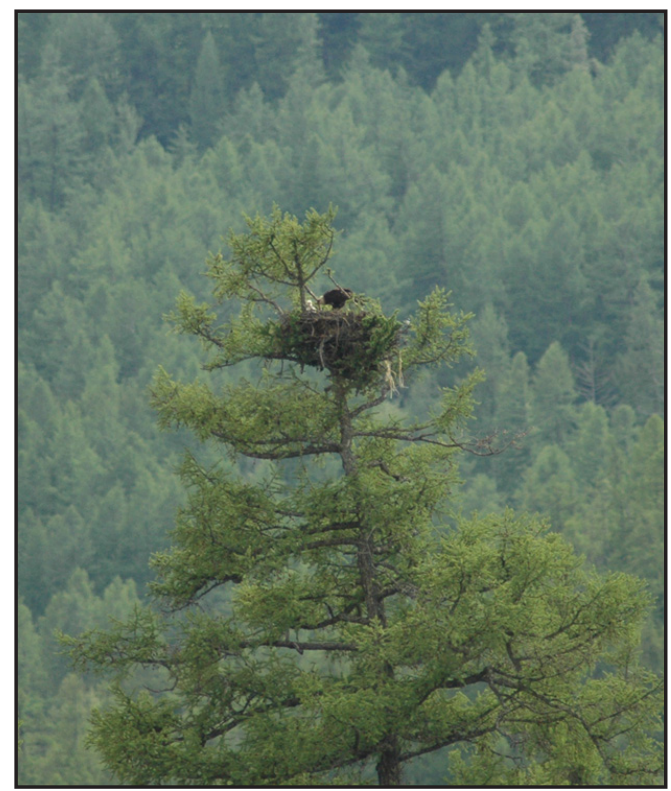



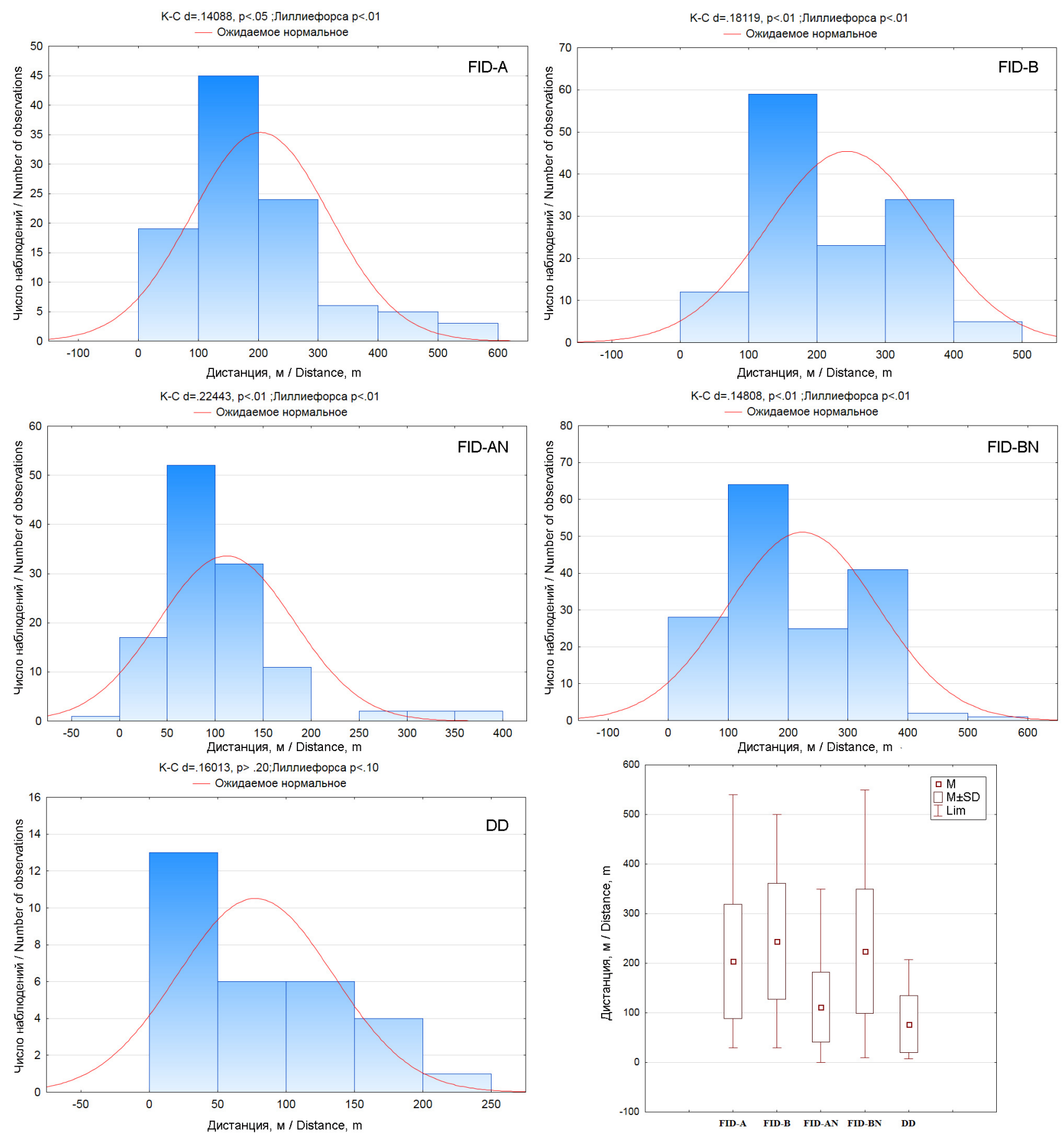

Рис. 12. Аистанции вспугивания (FID) орла-могильника (Aquila heliaca): FID-A - $А$ птицы на присаце в период насиживания яиц, FID-B - $о$ птицы на присаце в период выкармливания птенцов, FID-AN - $\Delta$ о птицы на гнезде в период насиживания яиц, FID-BN на гнезде в период выкармиивания птенцов; DD -дистанции от гнёзд орла-моигльника, до края зоны нарушений, на которых гнёзда бросаются птицами.

Fig. 12. Flight initiation distances (FID) for the Imperial Eagle (Aquila heliaca): FID-A - for a bird on a perch during incubation period, FID-B - for a bird on perch during the nestling-rearing period, FID-AN - for a bird in a nest during incubation period, FID-BN - for a bird in a nest during the nestling-rearing period; $D D$ - distances from abandoned nests of the Imperial Eagle to the edge of the disturbances zones.

на которой регистрировалось беспокойство орлов, варьировала от 50 Ао 580 м, составляя в среАнем (M $\mathrm{SE}) 252 \pm 115 \mathrm{M}$, а Аистанция вспугивания колебаиась от 1 Ао 1000 м, в среднем 261_191 м (González et al., 2006).

В настояшее время в популяциях мо- гильника активно идёт процесс амаптации к обитанию вила в условиях нарастаюшего антропогенного изменения его местообитаний. Там, гле большее количество пар, выработало толерантность к опреАелённым типам нарушений со стороны человека, они дами толчок к расселению 


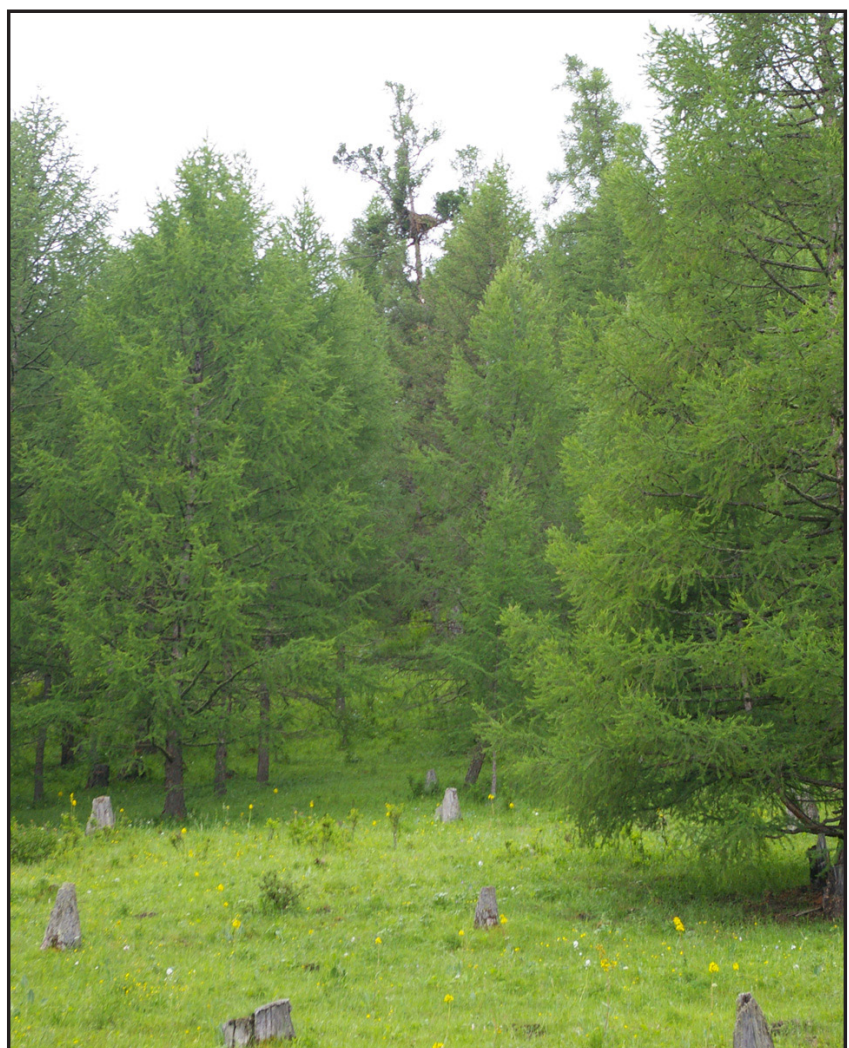

орлов в субоптимальные с точки зрения безопасности гнёзд, но богатые кормами местообитания. Как следствие, у пар, занимаюших изменённые человеком территории, несколько иные реакции на нарушения, нежели у пар, которые продолжают гнездиться на малоосвоенных территориях.

По нашим Аанным максимамьные показатели FID отмечены мля могильников вне гнёзд (на присахах) в период выкармиивания птенцов - $(n=133) 244,21 \pm 116,90$ (30-500 м, медиана и мода - 200 м), в то время как в период насиживания яиц они были несколько меньше - $(n=102)$

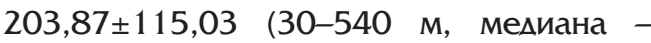
180 м, мода - 300 м) (рис. 12). Аистанция вспугивания птиц с гнёзА в периоА киацки составила ( $n=119) 111,36 \pm 70,62$ (0-400 м, медиана и мода - 100 м), в период выкармиивания выводков - $(\mathrm{n}=161)$ $224,30 \pm 125,69$ (10-550 м, медиана и мода - 200 м). Минимаяьная дистанция от гнезда орла-могильника, устроенного на дереве в ^есном киастере (здесь не берём в учёт

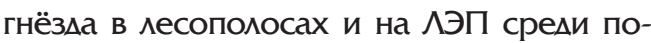
лей) $\Delta$ к края зоны нарушений, на которой гнездо осталось жилым, составляет 117 м (всего обнаружено два жилых гнезда в зоне менее 210 м $А$ края выборочной рубки), при средней Аистанции DD, на которой гнёзда оказаиись брошенными - $(n=30)$ 77,50 $\pm 56,93$ м, от 7 Ао 207 м (рис. 12).
Гнездо могимьника, брошенное птицами после рубки, проведённой на опушке леса (Республика Аитай). Фото И. Карякина.

The nest of the Eastern Imperial Eagle abandoned by birds after felling at the edge of the forest (Republic of Altai). Photo by I. Karyakin.

Аяя Испании рекомендован минимаиьный радиус охранной зоны вокруг гнёзд испанского могильника 500 м и 800 м, которые могут предотвращать $95 \%$ и $99 \%$ реакций беспокойства орлов соответственно (González et al., 2006). Эти рекомендации признаны чрезмерными мия птиц, осваиваюших агроценозы и иные нарушенные человеком территории (Horvath, 2009), но вполне актуаньны мя малонарушенных территорий. В той же Венгрии размер буферных зон вокруг гнёзд орла-могильника, в которых запрешены кюбые госрочные нарушения, вкАючая рубки, составляет 100-200 м, а в гнездовой период (1 февраля - 15 августа) рекоменАован рахиус буферных зон 300-600 м или 28,26-113,04 га (Pongracz, Horvath, 2010). С. Витер (2014) мля лесов Харьковской области Украины рекомендует также Аовольно большие бусерные зоны вокруг гнёзд орла-могильника - не менее 500 м (оптимум - от 600 до 700 м). Аия Ураиьского региона России премлагаиись бусерные зоны вокруг гнёзд орла-могильника рахиусом от 100 м Ао 1 км исходя из преАставлений об особенностях биологии конкретных пар, в которых рекомендовался запрет на ^юбое изменение ландшаста (рубки, прокиалку трасс, разработку полезных ископаемых и т.А.) с сохранением сложившегося природопользования (Карякин, 1998).

В Красной книге Ростовской области прописана необходимость строгой охраны всех известных гнездовий и запрешение рубок леса вокруг них на плошади 5 га (Белик, 2014). Вылеление киючевых биотопов с последуюшим созданием особо зашитных участков лесов на опушках ленточных боров, представленных лесными насаждениями естественного происхождения, шириной 100 м от границы леса с открытыми пространствами, а также радиусом 300 м вокруг гнёзд утверждено в качестве меры охраны мля орла-могильника в Красной книге Аитайского края (Важов и Ар., 2016).

Согласно нашим исследованиям, обоснованный рахиус бусерной зоны вокруг гнезда орла-могильника Аолжен быть не менее 162 м (табл. 5), в оптимаиьном 
варианте - 324 м. Аия стандартизации размеров буферных зон мия видов, внесенных в Красную книгу РФ и имеюших крупные гнёзда (1 м и более), необходимо придерживаться радиуса 500 м.

\section{Большой подорлик (Aquila clanga)}

С 1994 по 2016 гг. большой подорлик имеет статус уязвимого вида (VU) в Красном мисте МСОП (BirdLife International, 2017а). Основная часть ареала вила сосредоточена в России (Карякин, 2008а). В Европе лишь в Беларуси имеется популяция численностью 120-160 пар (Аомбровский, 2013), самый западный край которой заходит в Польшу (Maciorowski, 2012). Поэтому по Аанному виду фактически отсутствует инсормация об его ответах на беспокойство и нарушения, так как в основном ареале большого подорлика исследования по этому направлению экологии вида Ао сих пор не являмись приоритетными.

В Польше, Беларуси и Европейской части России большой подорлик гнездится в лесо-болотных ландшастах, преимушественно в ольшаниках (Гринченко и Ар., 2008; Карякин, 2008а; 2008с; Maciorowski et al., 2014; Аомбровский, 2013), причём мля Беларуси отмечена отрицательная кореляция гнездовой плотности с Аолей агроценозов в местах обитания $(r=-0,42$, $P<0,01)$ и сухих лесов $(r=-0,40, P<0,01)$ и положительная - с Аолей болот $(r=0,68$, $P<0,0001)$ и заболоченных лесов $(r=0.38$, $P<0.01$ ) (Dombrovski, 2012). Поэтому в запанной части своего гнездового ареала большой подорлик в основном избегает беспокойства, и отчасти нарушений, связанных с рубками, хотя рубки черноольшаников и указываются мия него одной

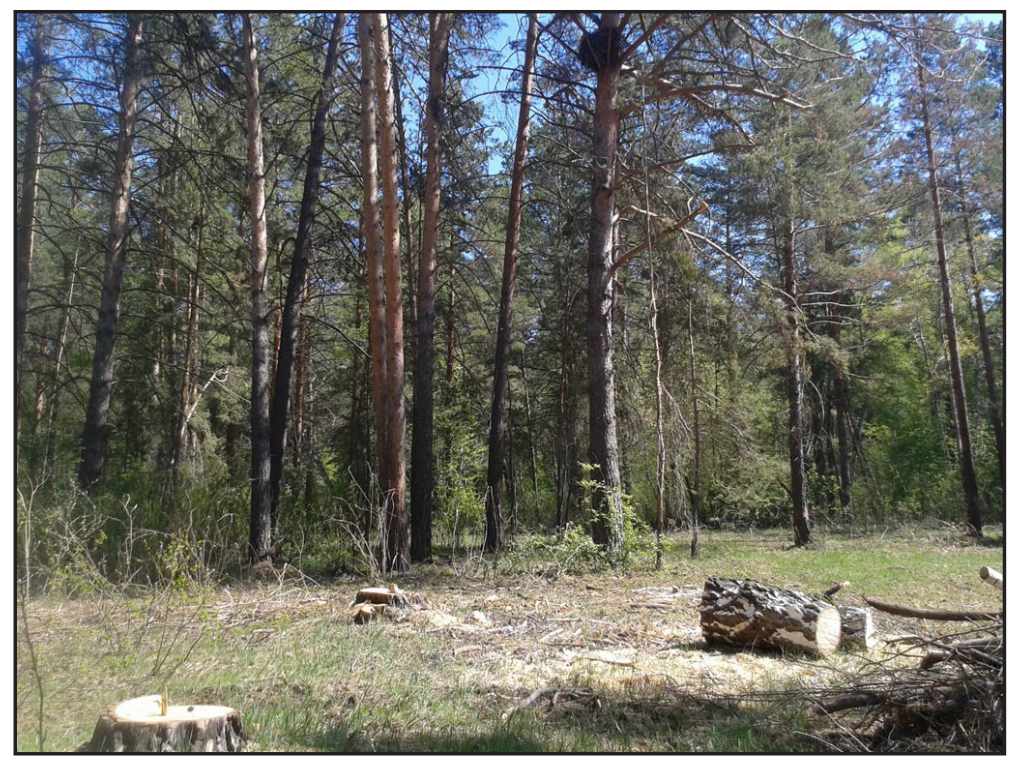

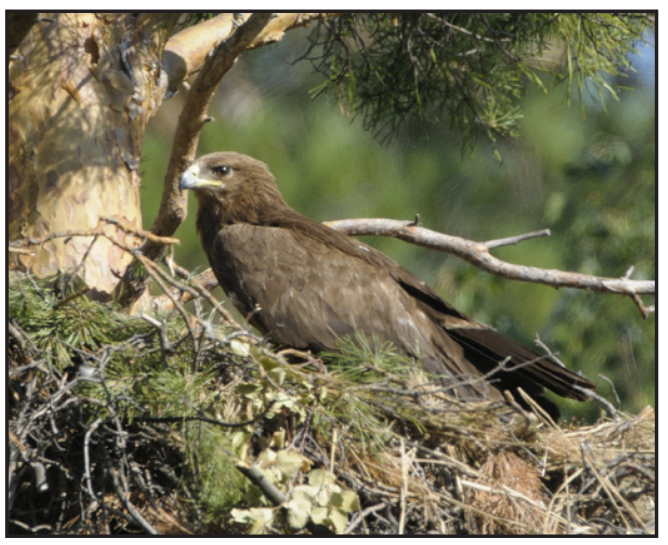

Большой подорлик (Aquila clanga) на гнезде (Завьямовский заказник, Аитайский край) Фото К. Бартошук.

Greater Spotted Eagle (Aquila clanga) on the nest (Zavialovskiy Nature Reserve, Altai Kray). Photo by K. Batoszuk.

из основных угроз, наряду с разработкой низинных болот, осушением пойм и спрямлением русел заболоченных рек (Ивановский, 2012). Но в Сибири большой подорлик устраивает гнёзаа в сухих борах вАОль болот (Карякин, 2008а; 2008d), в связи с чем, рубки являются мия него такой же проблемой, как дия близкого вида - ма^ого подорлика в Европе (Lohmus, 2005).

По нашим Аанным максимальные показатели FID отмечены мия больших подормиков вне гнёзд в период выкармливания птенцов - $(n=176) 86,56 \pm 56,26$ (2-200 м, медиана - 80 м, мода - 100 м), в то время как в период насиживания яиц они быхи несколько меньше - $(n=134) 82,97 \pm 55,02$ (10-200 м, медиана и мода - 80 м) (рис. 13). Аистанция вспугивания птиц с гнёзд в период киалки составила $(n=165)$

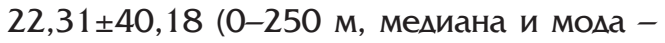
10 м), в период выкармиивания птенцов - $(n=202) 88,18 \pm 62,24$ (3-400 м, медиана - 85, мода - 100 м). Следует отметить, что 10,3 \% птиц на киамках из 165 не взлетели при проходе наблюдателей под гнездом, а $35,76 \%$ взлетели с дистанции менее 10 м (в 16 случаях из 59 гнёзда были устроены

Гнездо большого подорлика, брошенное птицами после проведенной рядом с ним рубки (А^тайский край). Фото И. Карякина.

A nest of the Greater Spotted Eagle abandoned by birds after felling nearby (Altai Kray).

Photo by I. Karyakin. 

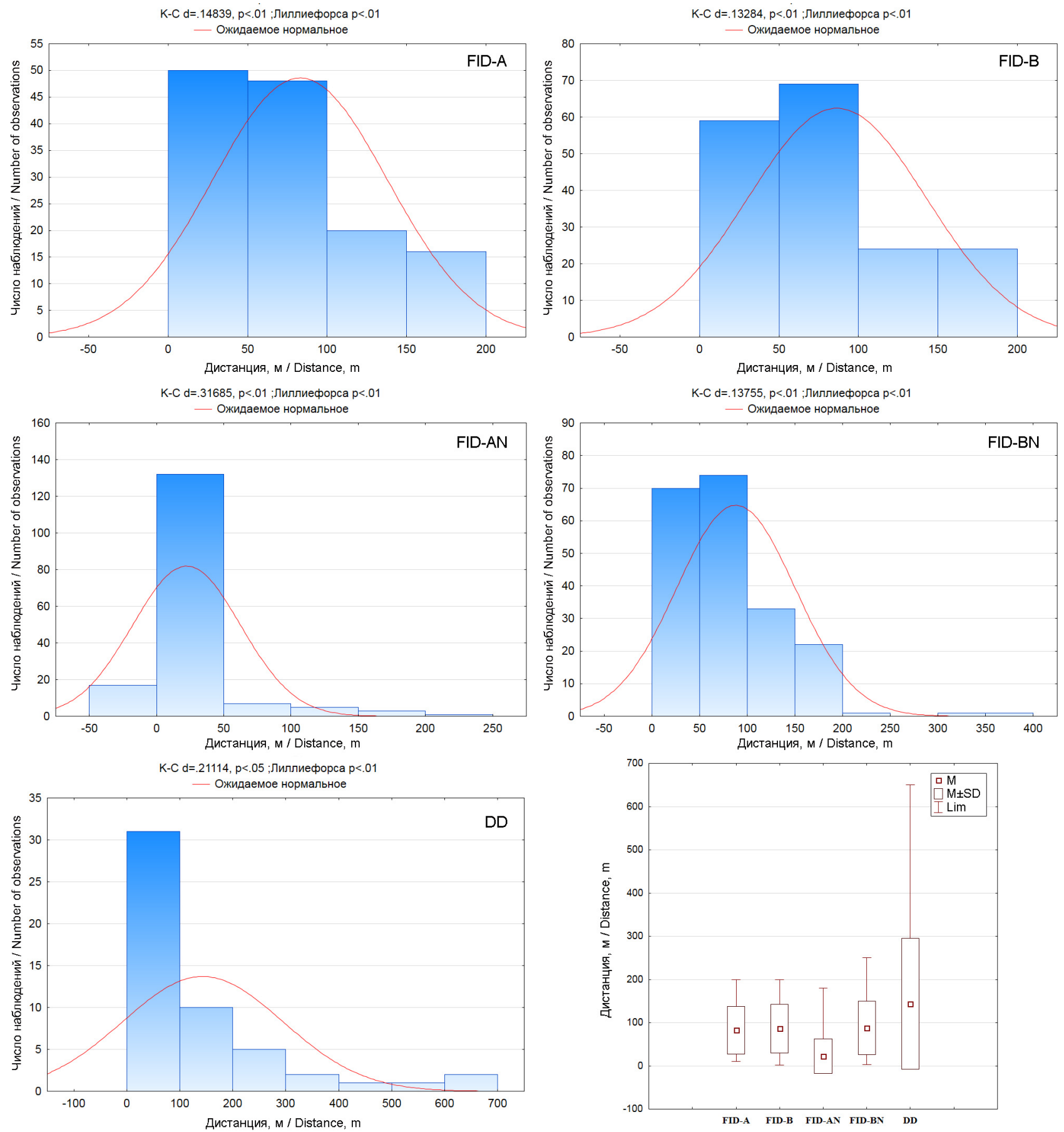

Pис. 13. Аистанции вспугивания (FID) большого подорлика (Aquila clanga): FID-A - до птицы на присаце в период насиживания яиц, FID-B - АO птицы на присаце в период выкармливания птенцов, FID-AN - $\Delta$ птицы на гнезде в период насиживания яиц, FID-BN - $\Delta O$ птицы на гнезде в период выкармливания птенцов; DD - дистанции от гнёзд большого подорлика, Ао края зоны нарушений, на которых гнёзда бросаются птицами.

Fig. 13. Flight initiation distances (FID) of the Greater Spotted Eagle (Aquila clanga): FID-A - for a bird on a perch during incubation period, FID-B - for a bird on perch during the nestling-rearing period, FID-AN - for a bird in a nest during incubation period, FID-BN - for a bird in a nest during the nestling-rearing period; $D D$ - distances from abandoned nests of the Greater Spotted Eagle to the edge of the disturbances zones.

на соснах, на высоте более 8 м, в остальных случаях на низкобонитетных соснах и берёзах на высоте менее 8 м).

Минимальная дистанция от гнезда большого подорлика $о$ края зоны нарушений, на которой гнездо осталось жилым, со- ставляет 126 м (всего обнаружено 6 жилых гнёза в зоне менее 650 м до края выборочной рубки), при средней дистанции $\mathrm{DD}$, на которой гнёзда оказамись брошенными - (n=52) 143,27 $\pm 151,44$ м, от 13 А 650 м (рис. 13). 
Аия близкого вида - малого подорлика (Aquila pomarina) в Эстонии в ралиусе 100 м от гнёзд полностью запрешены рубки и мюбая мругая экономическая деятельность, направленная на использование природных ресурсов, а также строительство зАаний; ремонт сушествуюших каналов и миний связи, проезА по лесу на транспорте и посешение территории ^юдьми (за искґючением научных исследований, природоохранного контроля и налзора и спасательных работ) разрешаются только с 1 октября по 29 февраия (Vali, 2003). Тем не менее, это считается недостаточным мия сохранения вида и предлагается вылелять буферные зоны не в виде круга радиусом 100 м, а по естественным границам за пределами этого круга (см. например, Карякин, Николенко, 2015а), а в 300-метровой зоне вокруг гнёз Аюбых рубок рекомендуется избегать с 1 марта по 30 сентября, также не проводить в этой зоне сплошных рубок или, если это необходимо, сплошные рубки Аолжны быть плошаАью менее 0,2 га (Vali, 2003). В Венгрии размер бусееных зон вокруг гнёзд малого подорлика, в которых запрешены ^юбые Аолгосрочные нарушения, вкиючая рубки, рекомендуется 300 м (28,26 га), а в гнездовой период (15 марта - 31 августа) рекомендован радиус бусрерных зон 400 м (50,24 га) (Pongracz, Horvath, 2010). Аля Украины размер буферных зон вокруг гнёзд малого подормика, в которых запрешены рубки, рекомендуется в радиусе 400 м (Витер, 2014), при этом в Красной книге Украины мля малого и большого подорликов закреплено требование вылеления бусерных зон в 500-х метрах вокруг гнёзд в качестве микрозаказников (Аомашевский, 2009; Аомашевский, Стригунов, 2009). В Беларуси вокруг взятых под охрану известных гнёзд малого подорлика в Витебской области выделены охранные зоны радиусом 50-250 м (Аомбровский, Ивановский, 2006). В Ураиьском регионе России были предложены бусерные зоны от 100 м до 1 км вокруг гнёзд подорлика, в которых следовало запрешать кюбое изменение ландшаста (рубки, прокиалку трасс, разработку полезных ископаемых и т.А.) (Карякин, 1998).

В Красной книге России декиарируется необходимость объявлять памятниками природы гнёзда большого подорлика, расположенные на неохраняемых территориях, с установлением вокруг них охранных зон, с полным запретом рубок и мелиоративных работ, однако размеров охранных зон не приводится (Мишенко, 2001). Необходимость вылеления вокруг гнёзд большого подорлика охранной зоны радиусом не менее 500 м утверждена в Красной книге Нижегородской области (Бакка, 2014b). Вылеление киючевых биотопов с последуюшим созданием особо зашитных участков леса в радиусе не менее 300 м от гнезда с запретом всех видов рубок в любое время года, геологоразведки, разработки полезных ископаемых, строительства и иной хозяйственной и рекреационной деятельности закреплено в Красной книге Алтайского края (Важков, Бахтин, 2016а).

Согласно нашим исследованиям, обоснованный рамиус бусерной зоны вокруг гнезда большого подорлика Аолжен быть не менее 388 м (табл. 5), в оптимальном варианте - 776 м. Аия стандартизации размеров буферных зон мия видов, внесённых в Красную книгу РФ и имеюших крупные гнёзаа (1 м и более), необхоАимо придерживаться радиуса 500 м, но при однозначной видовой приначмежности гнезда подорлику, буфер Аолжен быть увеличен $А$ 800 м.

\section{Орёл-карлик (Hieraaetus pennatus)}

Ешё в 80-х XX столетия было признано, что современные методы лесоводства имеют неблагоприятное влияние на орла-карлика в виду его особенностей в выборе мест гнездования (Gensbol, 1986). Во Франции с середины $1980-x$ годов около 30 \% гнезАовых участков карликов было брошено птицами по причине беспокойства, сплошных рубок или прореживания определённых участков леса весной, и Аругих вилов рубок летом и осенью (Carlon, 1996). В Национацьном парке Аонана (юго-запацная часть Испании) отмечено, что карлики терпят определённое беспокойство со стороны человека, тем не менее, гнездятся, в основном, в районах с более низкой плотностью линий электропередачи и необорудованных дорог (Suarez et al., 2000). В Каталонии дистанции от загородных $А$ мов $А$ занятых гнёзд орла-карлика соста-

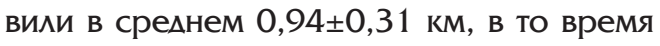

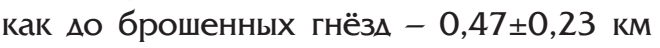
( $t$-value $=3,63, \quad p=0,002)$, от ближайших населённых пунктов $\Delta$ з занятых гнёзд 4,02 $\pm 2,01$ км, $\Delta$ о брошенных - 3,19 $\pm 2,24$ (t-value $=0,90, p=0,378)$, при этом карлики гнездились Аостаточно близко к дорогам (Bosch et al., 2005). На востоке Украины карлики мля гнездования выбирают наибо- 

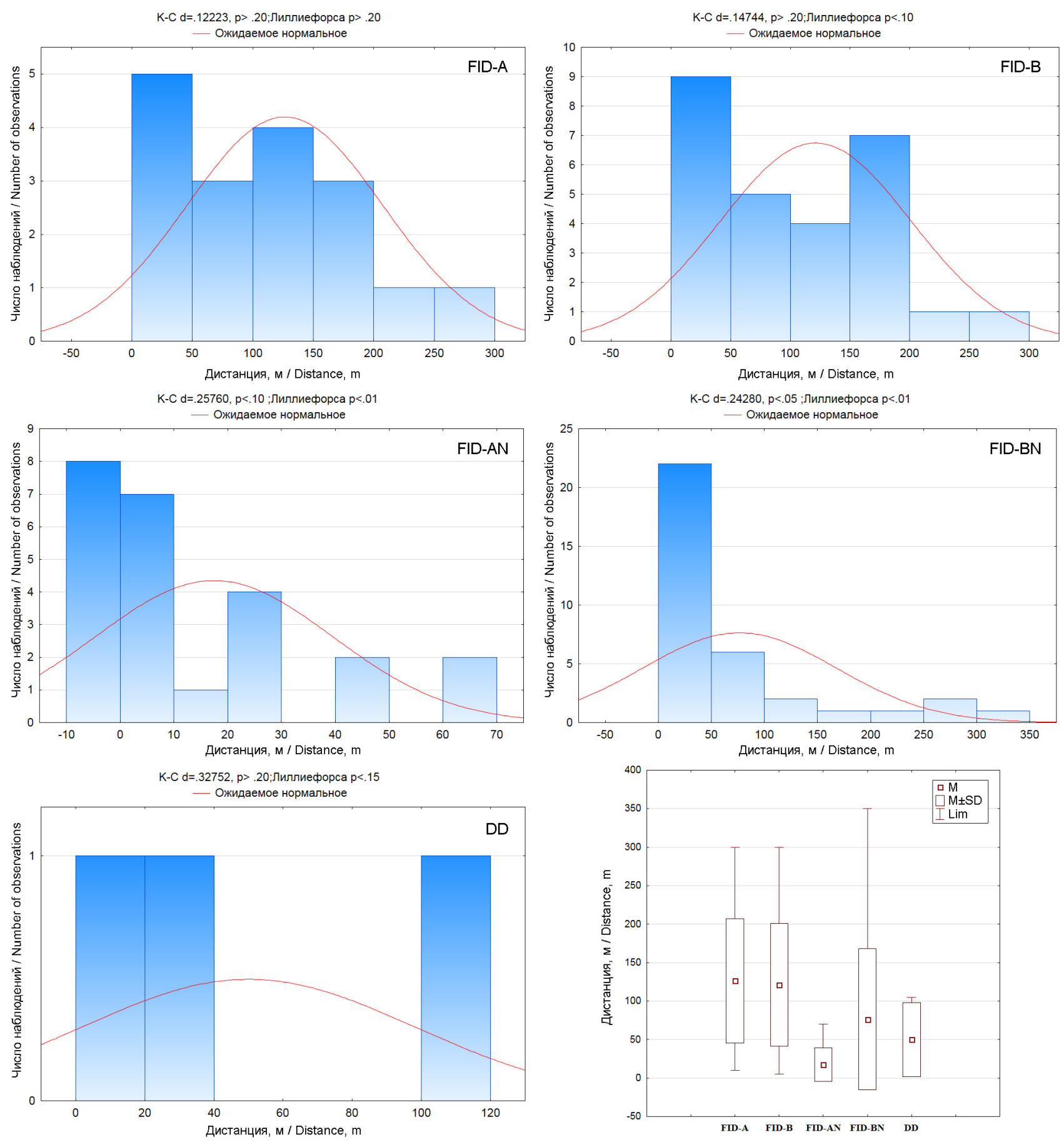

Pис. 14. Аистанции вспугивания (FID) орла-карлика (Hieraaetus pennatus): FID-A - Ао птицы на присаце в период насиживания яиц,

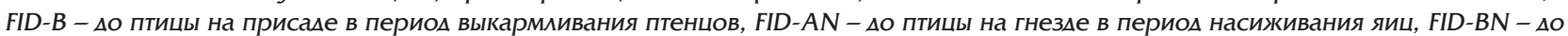
птицы на гнезде в период выкармливания птенцов; DD - дистанции от гнёзд орла-карлика, Ао края зоны нарушений, на которых гнёзда бросаются птицами.

Fig. 14. Flight initiation distances (FID) for the Booted Eagle (Hieraaetus pennatus): FID-A - for a bird on a perch during incubation period, FID-B - for a bird on perch during the nestling-rearing period, FID-AN - for a bird in a nest during incubation period, FID-BN - for a bird in a nest during the nestling-rearing period; $D D$ - distances from abandoned nests of the Booted Eagle to the edge of the disturbances zones.

лее старые высокоствольные участки леса, которые граничат с обширными степными массивами, открытыми куговинами, помями, заболоченными участками и водоёмами (Мороз, Ветров, 2013). В России в распределении карлика на гнездовании наблюдается устойчивая отрицательная корреляция с большой степенью фрагментированности лесов $(r=-0,767 ; p<0,001)$ и абсолютным доминированием в лесонасажлениях берёзы $(r=-0,657 ; p<0,001)$, и устойчивая положительная корреляция распределения гнёзА карлика с речными Аолинами $(r=0,897 ; p<0,005)$, гле сохра- 


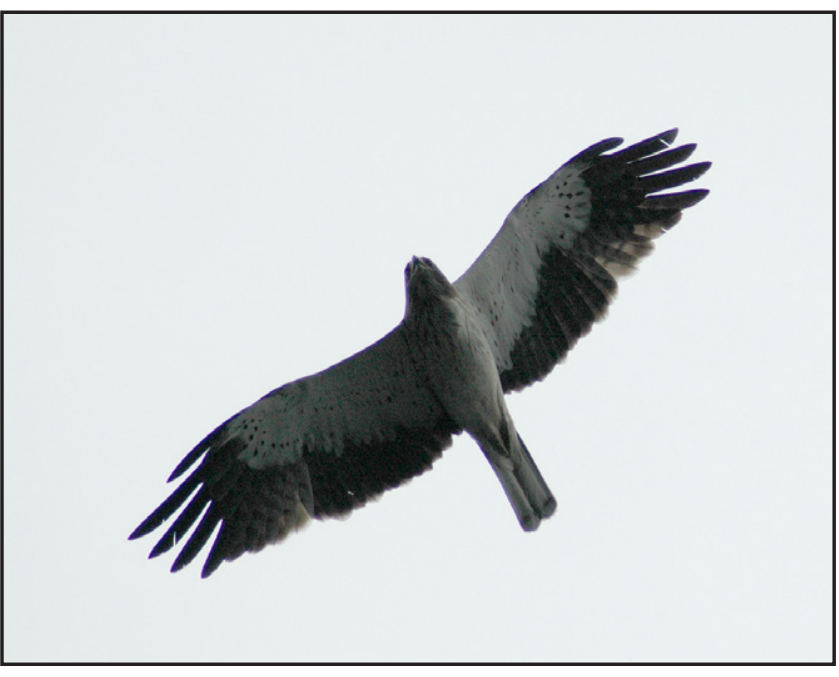

Орёл-карлик (Hieraaetus pennatus). Фото И. Карякина.

Booted Eagle (Hieraaetus pennatus). Photo by I. Karyakin. покойства (Карякин, 2007). нились максимальные плошади малонарушенных лесов и, часто, ниже фактор бес-

В зоне наших исследований мя целей Аанной статьи орёл-карлик не является характерным гнездяшимся видом, поэтому информации по нему было собранно крайне мало.

Показатели FID мяя орлов-карликов вне гнёзА в период насиживания яиц состав-

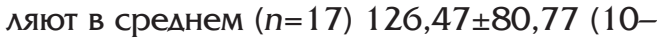
300 м, медиана - 120 м, мода - 50 м), в то время как в период выкармливания птенцов они были несколько меньше - $(n=27)$ $121,30 \pm 79,83$ (5-300 м, медиана - 100 м, мода - 50 м) (рис. 14). Аистанция вспугивания птиц с гнёзА в период киахки составила в среднем $(n=24) 17,46 \pm 22,02$ (0-70 м, медиана - 7 м, мода - 0 м), в период выкармливания птенцов - $(n=35) \quad 76,54 \pm 91,41$ (1-350 м, медиана - 50, мода - 20 м). На киалках карлики затаиваются и плотно лежат в гнезде, чем напоминают коршунов, однако Аистанции вспугивания вне гнёзА больше приближаются к настояшим орлам, нежели к хишникам среднего размерного киасса, к которым относится этот виА.

Средняя дистанция DD, на которой гнёзда оказались брошенными - $(n=3)$ 50,0 $\pm 48,22$ м, от 15 мо 105 м (рис. 14). Причём в диапазоне дистанций от 106 оо 200 м от края зоны нарушений нам не известно жилых гнёзд орла-карлика, соответственно очень сложно сказать, является ли зона в 200 м критической мля этого вида, или возможно успешное гнездование ближе к зоне нарушений.

В Венгрии мля сохранения орла-карлика рекомендованы двухуровневые буферные зоны ралиусом 300 м в которых в 200-метровой зоне искиючаются рубки и в зоне от 200 мо 300 м искиючается фрактор бес- покойства в период 15 марта по 15 августа (Pongracz, Horvath, 2010). Аля Украины рекомендуются бусрерные зоны вокруг гнёзд карлика, искиючаюшие рубки, рахиусом не менее 300 м (Витер, 2014).

Красная книга Нижегородской области определяет необходимость вылеления охранных зон вокруг гнёзд карлика радиусом не менее 200 м (Бакка, Киселева, 2014). В Красной книге Алтайского края требуется выделение киючевых биотопов с последуюшим созданием особо зашитных участков лесов в радиусе не менее 300 м от гнёзд орла-карлика с запретом мюбых рубок в Аюбое время года и иной хозяйственной деятельности, способной оказать негативное влияние на гнездяшихся птиц и привести к гибели гнезда. Также мля этого вида определена необходимость полного запрета беспокойства птиц и нахождения на гнездовом участке мюдей в период с 1 апреля по 1 августа (Ирисова, 2016b).

Наших Аанных недостаточно, чтобы предложить обоснованный радиус буферной зоны вокруг гнёзд орла-карлика, но он, определённо, Аолжен быть не менее 200 м, исходя из того, что ближайшие к зоне нарушений жилые гнёзда карлика располагаиись на Аистанциях Аалее 200 м. Ая стандартизации размеров бусерных зон мия вилов, имеюших гнёзда размером от 0,4 до 1 м, необходимо придерживаться рахиуса 300 м.

\section{Чёрный коршун (Milvus migrans)}

Чёрный коршун известный синантроп со скионностью к обитанию в селитебных ландшастах и среди евразийских виАОв хищных птиц отличается максимальной толерантностью к человеку и его хозяйственной деятельности, гнезАясь Ааже в крупных городах и зимуя на пригородных свалках (Galushin, 1971; Blanco, 1997; Marchant, Higgins, 1993; Giacomo, Guerrieri, 2008; Бахтин, 2013; Kumar et al., 2014; Literak et al., 2017). В Алтайском крае, гле был собран основной материал по влиянию рубок леса на занятость гнёзА коршуна, этот вид гнездится Ааже в однорядных лесополосах (Бахтин, 2016) и среди городской застройки (Бахтин и Ар., 2010). Тем не менее, основная часть популяции этого вила сосредоточена в эксплуатируемых лесах, преимушественно в борах (Бахтин, 2013), гАе, впрочем, пространственные предпочтения вида при устройстве гнёзд сушественно отличаются от таковых Аругих хишных птиц (Важов, 2012). 

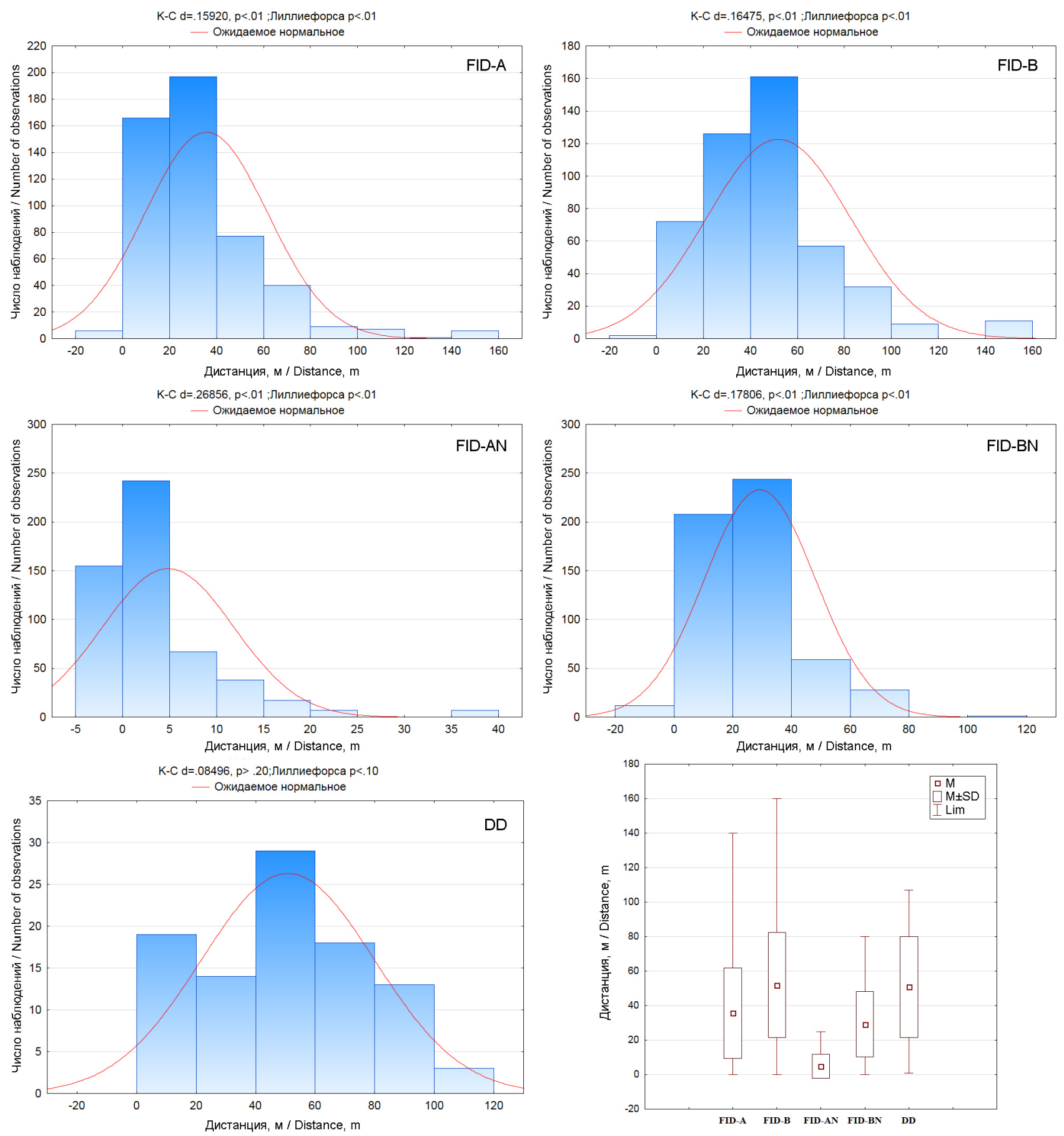

Pис. 15. Аистанции вспугивания (FID) чёрного коршуна (Milvus migrans): FID-A - Ао птицы на присахе в период насиживания яиц, FID-B - АO птицы на присахе в период выкармливания птенцов, FID-AN- - о птицы на гнезде в период насиживания яиц, FID-BN - $\Delta O$ птицы на гнезде в период выкармливания птенцов; DD - дистанции от гнёзд коршуна, Ао края зоны нарушений, на которых гнёзда бросаются птицами.

Fig. 15. Flight initiation distances (FID) for the Black Kite (Milvus migrans): FID-A - for a bird on a perch during incubation period, FID-B - for a bird on perch during the nestling-rearing period, FID-AN - for a bird in a nest during incubation period, FID-BN - for a bird in a nest during the nestling-rearing period; $D D$ - distances from abandoned nests of the Black Kite to the edge of the disturbances zones.

При серьёзных ацаптациях к гнездованию в освоенном человеком ландшасрте коршун не демонстрирует особой толерантности к беспокойству со стороны человека: по нашим Аанным максимаиьные показатели FID (мия птиц вне гнёзд в период выкармиивания птенцов) $(n=470) 51,99 \pm 30,58$ м (рис. 15$)$ харак- терны и мяя Аругих ястребиных среднего размерного киасса, минимальная дистанция от гнезда коршуна до края зоны нарушений, на которой гнезАо осталось жилым, составляет 64 м, при средней дистанции $\mathrm{DD}$, на которой гнёзда оказамись брошенными - (n=96) 50,83 $\pm 29,12$ м. 


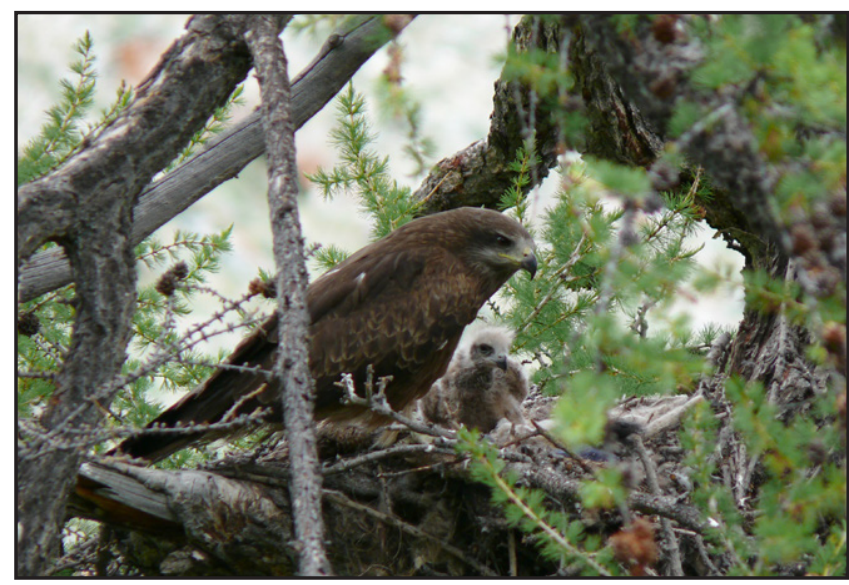

Чёрный коршун (Milvus migrans) на гнезде с птенцами. Фото Р. Бекмансурова.

Black Kite (Milvus migrans) with nestlings on the nest. Photo by R. Bekmansurov.
FID негнездяшихся коршунов во Франции определены в 37,91 м (по Авум регистрациям) (Møller, Erritzøe, 2010). Наょо отметить, что и в России негнездяшиеся птицы на ночёвках в лесополосах вАоль полей, на которых илёт уборка урожая, и особенно около свалок выдерживают в среднем аналогичные дистанции при подходе АюАей.

Аия близкого вида - красного коршуна (Milvus milvus) в Великобритании $\mathrm{AD}$ в период киалки определена в среднем 153 м, в период выкармливания птенцов - 159 м (медиана во все периоды 125 м), FID - в период киалки составляет в среднем 85 м (медиана 30 м), в период выкармливания птенцов - 118 м (медиана 75 м) (ция всех случаев 80-процентный интерваи 10-300 м) (Ruddock, Whitfield, 2007). Амя этого вила премложен размер бусрерных зон вокруг гнёзА 300-600 м (Currie, Elliott, 1997) и 400-600 м (Petty, 1998).

В Итальянских Аиьпах мия сохранения чёрного коршуна предлагается запрет рубок в километровой зоне вдоль побережья озёр и в 50 м от скальных обнажений, буферная зона вокруг гнёзд выделяется в радиусе 500 м, в которой запрешается строительство Аорог и ограничивается хозяйственная деятельность с 15 марта по 30 июля, а в идеале $о$ 30 августа; при рубках требуется оставлять 500-700 старых деревьев на гектаре леса (Sergio et al., 2003). В Венгрии мия чёрного коршуна премиагается бусрерная зона рахиусом 50-100 м с запретом кюбых продолжительных нарушений и 300 м - с запретом беспокойства в период с 1 марта по 31 июля (Pongracz, Horvath, 2010).

Согласно нашим исследованиям, обоснованный рахиус бусерной зоны вокруг гнезда коршуна, устроенного в естественном лесонасаждении за пределами зоны застройки, Аолжен быть не менее 90 м (табл. 5), в оптимальном варианте - 180 м. Аля стандартизации размеров бусерных зон мля видов, имеюших гнёзда размером от 0,4 Ао 1 м, необходимо придерживаться ралиуса 300 м, с определёнными послаблениями в режиме (выборочные рубки и рубки ухода) вне гнездового периода в зоне от 180 Ао 300 м.

Канюк обыкновенный (Buteo buteo)

Обыкновенный канюк - один из самых обычных пернатых хишников Евразии и, вероятно, самая многочисленная в своём размерном киассе хишная птица Европы, численность которой оценивается в 814 тыс. - 1,39 млн. пар, что соответствует 1,63-2,77 мин. взрослых птиц (BirdLife International, 2017c). Несмотря на свою обычность, канюк не проявляет тенденций к синантропизации в отличие от коршуна или тетеревятника. Ааже там, гАе канюк Аостаточно толерантен к хозяйственной деятельности человека, он сохраняет активные реакции на беспокойство ^юдьми. Исследования в Аании показаяи, что за более чем 34-летний период канюки проАолжают Аистанцироваться на гнездовании малее 40-50 м от Аорог, а Аистанции вспугивания не коррелируют с близостью гнёзА к Аорогам, жилью и объектам инсрраструктуры, что не подмерживает гипотезу о том, что канюки более терпимы к мюдям в нарушенных местообитаниях (Sunde et al., 2009). В предаиьпийской части Итамии наскаиьногнездяшиеся канюки дистанцирова-

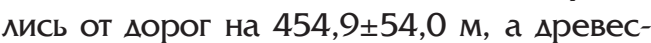
ногнездяшиеся - на 258,0 $\pm 38,4$ м от $\Delta$ орог и 790,2 $\pm 98,1$ м от населённых пунктов (Sergio et al., 2015). Практика управления лесами вносит свои коррективы в распределение и численность канюка, что показано на примере Испании, где канюк избегает территорий, с повышенным уровнем беспокойства людьми и нарушением лесных сообшеств (Zuberogoitia et al., 2004). B Великобритании, гле канюк является одним из самых многочисленных хищников, он, нарялу с беркутом и серой неясытью отнесён к очень чувствительным к нарушениям видам и легко бросает гнёзда во время инкубации после вспугивания с киацки, иногАа после одного визита (Petty, 1998). В Финляндии канюк вообше вкиючён в Красный лист в качестве уязвимого вида (категория Vulnerable) по причине пацения численности в последние годы, и современная практика лесопользования стала не последней причиной этого падения (Mikkola-Roos et al., 2010). 
FID мяя канюков, встреченных в сельской местности, в Чехии составили в среднем $(n=3) 55,26 \pm 15,07$ м, в Аании - $(n=15)$ 60,01 22,8 м (Diaz et al., 2013). В Аругом исследовании в Аании самые пугливые канюки взлетами, как только наблюдатель подходил на 200 м к гнезду с насижива- ющей киацку птицей, 60 \% насиживаюших птиц всё ешё находились в гнезде при подходе наблюдателя к нему на 100 м, $40 \%$ - когла наблюдатель находился на расстоянии 50 м и $14 \%$ - при подходе наблюдателя к гнездовому дереву. Таким образом, в ^андшасрте с относительно высокой плот-


Pис. 16. Аистанции вспугивания (FID) обыкновенного канюка (Buteo buteo): FID-A - $\Delta$ п птицы на присаце в период насиживания яиц, FID-B - Ао птицы на присаце в период выкармиивания птенцов, FID-AN - $о$ птицы на гнезде в период насиживания яиц, FID-BN - $\triangle O$ птицы на гнезце в период выкармливания птенцов; DD - Аистанции от гнёзд канюка, до края зоны нарушений, на которых гнёзда бросаются птицами.

Fig. 16. Flight initiation distances (FID) for the Common Buzzard (Buteo buteo): FID-A - for a bird on a perch during incubation period, FID-B - for a bird on perch during the nestling-rearing period, FID-AN - for a bird in a nest during incubation period, FID-BN - for a bird in a nest during the nestling-rearing period; DD - distances from abandoned nests of the Common Buzzard to the edge of the disturbances zones. 




ностью людского населения (134 чел./км²), $86 \%$ из 213 насиживаюших птиц слетами с гнёзд при приближении человека на дистанциях от 0 Ао 200 м (Sunde et al., 2009). $\Delta$ ия негнездяшихся канюков в той же Аании FID при беспокойстве пешеходом определены в 22-228 м, в среднем $(n=25) 95$ м (Bijlsma, 2008). Во Франции FID канюков, встреченных в сельской местности, составили в среднем ( $n=9)$ 54,06 м (Møller, Erritzøe, 2010), в зоне городской застройки в г. Орсе в пригороде Парижа (плотность населения 2037 чел./км²) средние показатели FID для канюка (10 наблюдений), тетеревятника (4 наблюдения), перепелятника (8 наблюдений), пустельги (7 наблюдений) и чёрного коршуна (1 наблюдение) составили $(M+S E)$ 54,08+1,47 м (Møller, 2012).

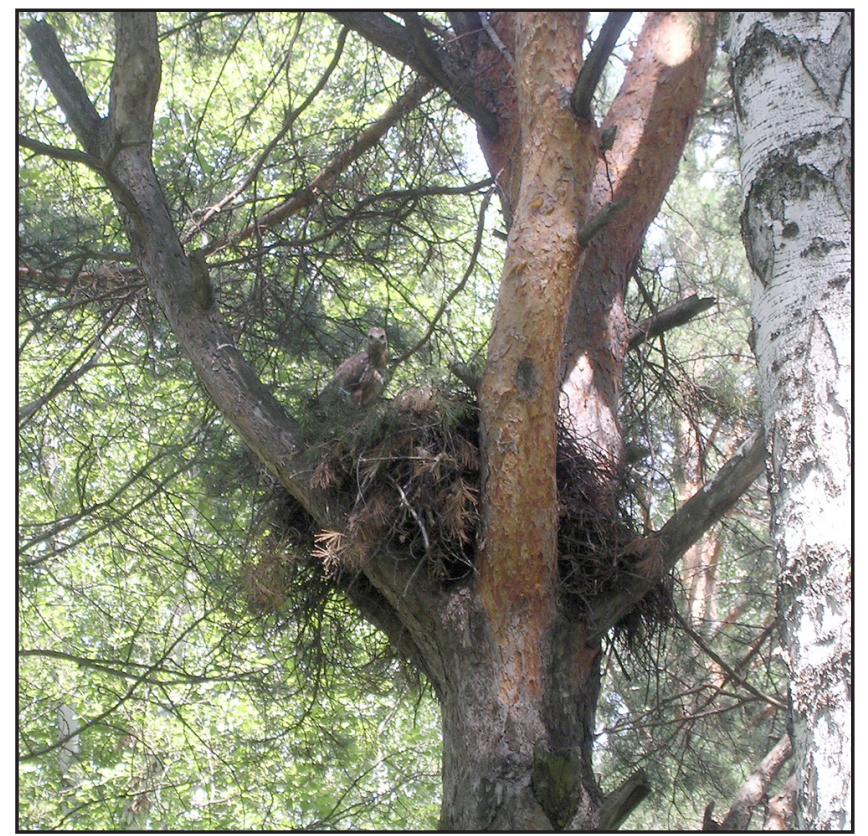

Канюк обыкновенный (Buteo buteo). Фото И. Карякина.

Common Buzzard (Buteo buteo). Photo by I. Karyakin.

По нашим Аанным показатели FID м^я канюков вне гнёзд в период насиживания яиц составили в среднем $(n=227)$ 35,81 24,95 (2-130 м, медиана - 30 м, мода - 40 м), в период выкармливания птенцов - $(n=203)$ 50,73 $\pm 33,94(2-160$ м, медиана - 45 м, мода - 60 м) (рис. 16). $\triangle$ истанция вспугивания птиц с гнёзд в период киахки составияа $(n=191) 9,87 \pm 10,36$ (0-55 м, медиана - 7 м, мода - 2 м), в период выкармливания птенцов - $(n=249)$

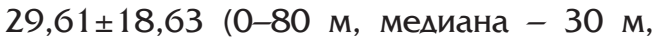
мода - 30 м). Не взлетели при проходе наблюдателей под гнездом 5,76 \% птиц на кладках из 191, а 51,83 \% взлетели с дистанции менее 10 м, с гнёзд с птенцами не взлетели 0,8 \% птиц из 249 при прохо$\Delta$ е под гнезАом, а 10,84 \% птиц покинули гнёзда с Аистанции менее 10 м.

Аля близкого вида - королевского канюка (Buteo regalis) в Нью-Мехико (США) опре$\triangle$ елена FID в среднем $(M \pm S E) 486 \pm 40,4$ м Аля взрослых канюков на гнёздах в сельских районах и 340 30,7 м - вблизи городов (Keeley, Bechard, 2011). В Монтане средние показатели FID определены в $202,8 \pm 157,4$ м $(n=87$, медиана - 160 , предел 75 \% вспугиваний - 280 м, 90 \% 430 м, 95 \% 532 м от гнезАа) (Van Horn, 1993), по более ранним исследованиям 170 м от гнезда ( $n=9)$ при беспокойстве пешеходом, 95 м $(n=10)$ - на мотоцикие, от 75 Ао 200 м - на машине, причём при подъезде на машине остановка вызывама реакцию вспугивания на большем расстоянии от гнезда (в среднем 140 м), чем без остановок (в среднем 90 м), при транзитных проходах на машине птица покидала киалку в среднем на дистанции 65 м, при прямом подъезде в направлении гнезда - в среднем 144 м (Ensign, 1983). В Айдахо средние показатели FID определены в 100 м (Hansen, 1994). В Аругом исслеАовании на юге Айдахо в разные годы в гнёздах королевского канюка с разным количеством птенцов средние значения 
FID варьировали от 31 до 196 м ( $n=141$, Аиапазон 10-400 м) при беспокойстве пешеходом, от 54 до 221 м (n=132, диапазон 15-500 м) при беспокойстве на автотранспорте и от 71 до 96 м (n=59, диапазон 5-320 м) при стрельбе из огнестрельного оружия; взрослые птицы не покидаяи гнёзда в $60 \%$ случаев, если деятельность исслеАователей осушествлялась Аалее 120 м от гнезда и в $90 \%$ - если они были на расстоянии более 250 м от него (White, Thurow, 1985). На зимовке в Колорацо при беспокойстве на автомобиле средние показатели FID составили $195 \pm 85$ м $(n=16$, Аиапазон 110-280 м), пешком - 63 99 м ( $n=24$, диапазон 13-165 м), причём доля вспугиваний составила 13 и $92 \%$ соответственно (Holmes et al., 1993). На юге Альберты и Саскачевана в Канаце за 3 года исследований были записаны FID мия 721 наблюдения канюков в 324 разных гнёзАах (406 случаев размножения), которые варьироваяи от 0 м до 950 м от гнезАа, составив в среднем 130 м (медиана - 74 м, 95 \% всех вспугиваний лежит в диапазоне от $0 \triangle \mathrm{O} 450$ м, в основном от $0 \Delta \mathrm{O} 150 \mathrm{M}$ ): FID у птиц, гнезАяшихся на Аеревьях, составима в среднем $(M+S E) 101,3 \pm 4,4$ м $(n=516)$,

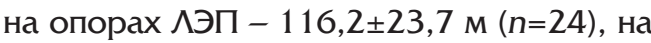

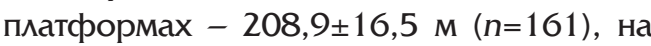

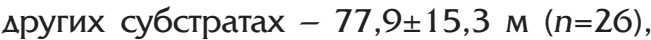
причём показатели незначительно изменямись по годам, составив в 2012 г. в среднем $138,2 \pm 7,8$ м $(n=314)$, в 2013 г. $-102,5+5,5$ $(n=343)$, в 2014 г. $-173,6+20,7$ м $(n=70)$ (Nordell, 2016). Автором также отмечено, что подъезд к гнёздам канюков на транспортных средствах по грунтовым Аорогам повышая вероятность вспугивания птиц больше, чем при Авижении по магистрами $(1,3 \pm 0,3)$, при подходе наблюдателя пешком к гнезду вероятность вспугивания птицы была почти в четыре раза больше

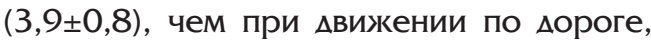
а выход из транспортного средства напротив гнезда приводия к вероятности вспугивания более чем в 5 раз $(5,3 \pm 1,2)$ по сравнению с проездом по магистрахи. Интересно и то, что вероятность вспугивания увеличивалась примерно на $18 \%$ при каждом последуюшем посешении гнезда $(1,18 \pm 0,06)$.

Аия близкого вила - зимняка (Buteo lagopus) Аистанции вспугивания зимуюших птиц в США автотранспортом варьировали от 9 Ао 170 м, составляя в среднем $(n=62)$ $71 \pm 8$ м, при вспугивании $40 \%$ от обшего числа встреченных, при этом пешеходы вспугивали 100 \% встреченных птиц на Аистанциях от 55 до 900 м, в среднем ( $n=45)$ 177 \pm 19 м (Holmes et al., 1993).

мия близкого вида - королевского канюка по исследованиям в Айдахо (США) премложен минимальный буфер 250 м вокруг гнезда, достаточный мля предотврашения вспугиваний птиц, по крайней мере, в $90 \%$ случаев, причём мля сезонов, когла численность жертв канюка высокая и птицы находятся в хорошем фризиологическом состоянии, а в случае сезонов с низкой численностью добычи, когла канюки менее терпимы к беспокойству, размер бусера Аолжен быть увеличен (White, Thurow, 1985). Исследование в Нью-Мехико показамо, что в сельской местности Аистанции в 648 м и в гороАской местности 480 м преАОтврашают вспугивание $95 \%$ гнездящихся канюков, на основании чего, чтобы свести к минимуму неблагоприятные последствия деятельности человека на гнездяшихся королевских канюков в Нью-Мехико, авторами рекомендован бусер 650 м или несколько больший (Keeley, Bechard, 2011).

В нашем исследовании средняя дистанция от гнезда канюка $А$ края зоны нарушений, на которой гнезАо осталось жилым, составляет ( $n=6)$ 57 $\pm 29,24$ м (19-80 м), при средней Аистанции DD, на которой гнёзда оказамись брошенными - $(n=39)$ $45,82 \pm 26,16$ м, от 1 Ао 84 м (рис. 16).

С. Витер (2014) предможия мия обыкновенного канюка в Украине буферную зону не менее 200 м, заметив, что более оптимальна охранная окологнездовая зона с радиусом около 300 м.

Согласно нашим исследованиям, обоснованный радиус бусерной зоны вокруг гнезда канюка должен быть не менее 52 м (табл. 5), в оптимальном варианте - 104 м. Аля стандартизации размеров бусерных зон мия видов, имеюших гнёзда размером от 0,4 Ао 1 м, необходимо придерживаться ралиуса 300 м, с определенными послаблениями в режиме (выборочные рубки и рубки ухода) вне гнездового периода в зоне от 100 Ао 300 м.

\section{Осоеды обыкновенный и хохлатый (Pernis apivorus, P. ptilorhynchus)}

$\Delta$ ва достаточно обычных вида, деляших

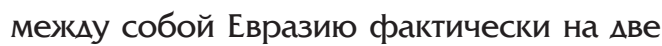
части по горам Центраиьной Азии - на запаце $А$ Алтая вкиючительно гнездится обыкновенный осоел, на востоке - от Алтая Ао Аамьнего Востока - хохиатый. В А^таеСаянском регионе оба этих вида смешиваются, однако ширина зоны гибридизации неизвестна. Учитывая динамично растушее 


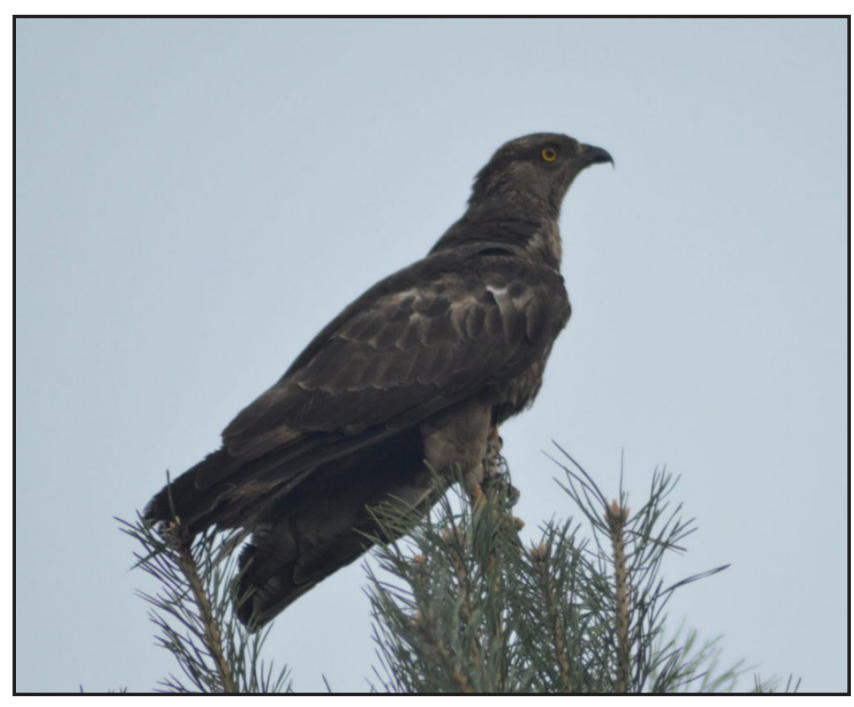

ежегодно число регистраций хохиатых осоелов на миграции через Аравийский полуостров (Babbington, Campbell, 2016), можно предполагать цостаточно глубокое проникновение хохлатого осоеда на запац по подтаёжной зоне Запанной Сибири, откуда птицы и уходят в миграцию в юго-запацном направлении. ОАнако пока это только гипотеза, так как гнездовые находки вида ограничены правобережьем Оби в её верховьях (Кучин, 2004; Рыжков, 2016; RRRCN, 2017).

Численность обыкновенного осоеАа в Европе оценивается в 118-171 тыс. размножаюшихся пар, что соответствует 235-342 тыс. взрослых птиц (BirdLife International, 2016а), однако мировая численность (менее 420 тыс. особей), оцененная также BirdLife International, явно занижена, по причине некорректной оценки плошади ареала вила в России. Учитывая 188,9-851,6 тыс. птиц, мигрируюших через Израиль (Yosef, 1995) в основном из Европейской части России и запацной части Запацной Сибири, можно предполагать верность оценок численности мировой популяции осоеда $А$ 1 млн. особей (Ferguson-Lees et al., 2001). Численность мировой популяции хохлатого осоеда оценивается также до 1 мин. особей (Ferguson-Lees et al., 2001), однако о какой-либо точности оценок говорить не приходится, так как мля большей части ареала этого вила, в том числе и в России, Ао сих пор не сушествует каких-либо данных учётов гнездяшихся птиц.

Аия обоих виАов среди угроз чисиится изменение местообитаний в ходе лесохозяйственной деятельности (BirdLife International, 2016а; 2016b), однако фактического материала по влиянию рубок или выбору местообитаний в осваиваемых человеком
Ocoеs (Pernis apivorus). Фото И. Карякина.

Honey Buzzard (Pernis apivorus). Photo by I. Karyakin.

лесах не так уж и много (в основном по Европе) и он крайне неоднозначен одни авторы указывают на тяготение осоеда к старым участкам леса, другие считают, что возраст леса и степень его нарушенности не имеют значение мия этого вида (Lohmus, 2005; Santangeli et al., 2012; Gamauf et al., 2013; Björklund et al., 2015). В частности, в Швеции отмечено, что осоеды $(n=30)$ выбирали мия гнездования участки меса более высокого бонитета $(5,6 \pm 1,6)$ и киасса возраста $(4,0 \pm 0,9)$, нежели в случайной выборке ( $n=32)(4,1 \pm 1,8$ и 3,2 $\pm 1,0$, соответственно) (Amcoff et al., 1994).

Аишь Аля негнездяшихся осоедов в Аании удаиось найти опубликованные Аанные по FID при беспокойстве пешеходом - 22-228 м, в среднем ( $n=25) 95$ м (Bijlsma, 2008), что мишний раз свидетельствует о слабой изученности и крайней скрытности вида.

По нашим Аанным показатели FID м^я осоедов вне гнёзА в период насиживания яиц составили в среднем $(n=49)$ 56,80 50,67 (1-200 м, медиана - 40 м, мода - 30 м), в период выкармливания птенцов - $(n=55)$ 55,02 $\pm 53,68$ (1-200 м, медиана и мода - 30 м) (рис. 17). Аистанция вспугивания птиц с гнёзА в период киахки составила $(n=60)$ 8,42 $\pm 12,35(0-50$ м, медиана - 3 м, мода - 0 м), в период выкармливания птенцов - $(n=52) \quad 50,21 \pm 39,78$ (0-180 м, медиана - 50 м, мода - 30 м). Не взлетели при проходе наблюдателей под гнездом 38,33 \% птиц на киадках из 60, а 28,33\% взлетели с Аистанции менее 10 м, с гнёзА с птенцами не взлетели 5,77 \% птиц из 52 при проходе под гнезАом, а 17,31 \% птиц покинули гнёзда с дистанции менее 10 м. Средняя дистанция от гнезда осоела до края зоны нарушений, на которой гнездо остаАось жилым, составляет (n=3) 83,33 $\pm 25,17$ м (60-110 м), при средней дистанции DD, на которой гнёзда оказались брошенны-

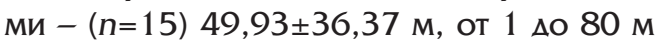
(рис. 17). Таким образом, опасным мия осоеАа можно считать диапазон Аистанций от гнёзА $\Delta$ о зоны нарушений - 120 м, причём Ааже в случае прохождения леса выборочными рубками.

Весьма вероятно, что избегание осоеАом леса, прорежённого выборочной рубкой, связано с его уходом от хишнического пресса со стороны тетеревятника, который регулярно наблюдается в сосно- 

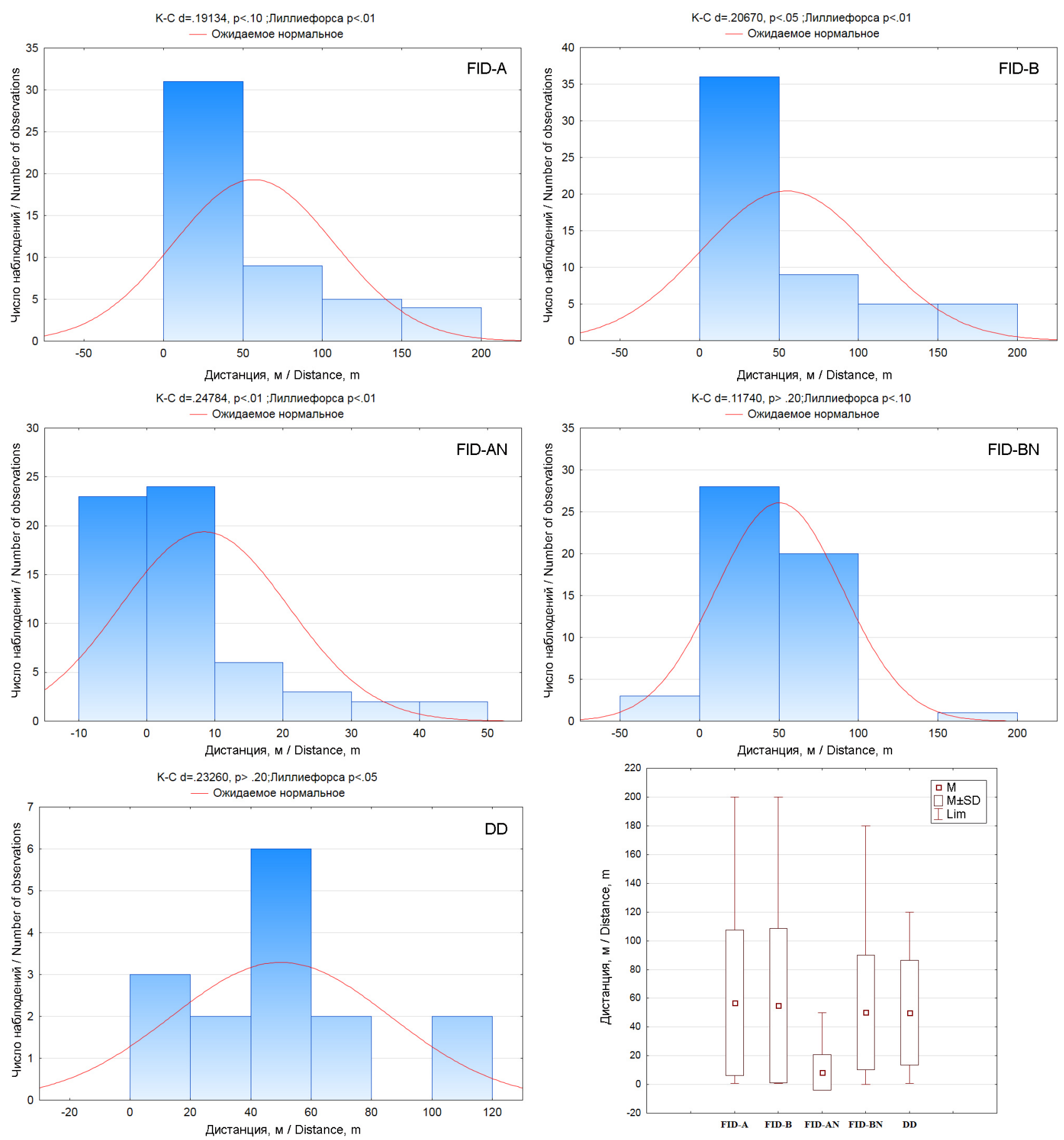

Pис. 17. Аистанции вспугивания (FID) обыкновенного осоеда (Pernis apivorus): FID-A - $\Delta о$ птицы на присаце в период насиживания яиц, FID-B - Ао птицы на присаце в период выкармиивания птенцов, FID-AN - $о$ птицы на гнезде в период насиживания яиц, FID-BN - $о$ птицы на гнезде в период выкармиивания птенцов; DD - Аистанции от гнёзд обыкновенного осоеда, $о$ края зоны нарушений, на которых гнёзда бросаются птицами.

Fig. 17. Flight initiation distances (FID) for the Honey Buzzard (Pernis apivorus): FID- $A$ - for a bird on a perch during incubation period, FID-B - for a bird on perch during the nestling-rearing period, FID-AN - for a bird in a nest during incubation period, FID-BN - for a bird in a nest during the nestling-rearing period; $D D$ - distances from abandoned nests of the Honey Buzzard to the edge of the disturbances zones.

вых, лиственничных и лиственных лесах, и менее выражен в ненарушенных рубками широколиственных и хвойно-широколиственных лесах, особенно елово-липовых, обеспечиваюших большую укрытость гнёзд. Похожие наблюдения имеются в Европе (см., например Bijlsma, 2004; Ga- mauf et al., 2013). Если есть недостаток в участках меса, обладаюших хорошими зашитными свойствами, это вызывает конкуренцию за доступные места мяя гнездования среди хишников среднего размерного киасса. В этой конкурентной борьбе осоеА и канюк, как более слабые и более позА- 


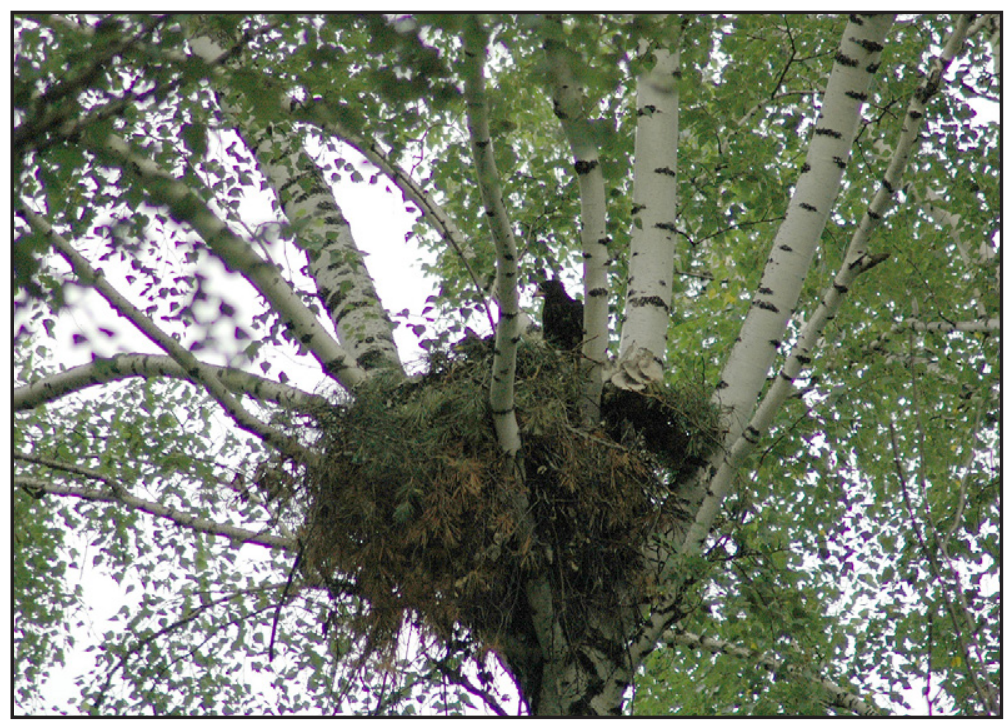

но гнездяшиеся, проигрывают тетеревятнику (Hakkarainen et al., 2004). Это нало учитывать при планировании охраны гнёзА осоела в районах совместного обитания с тетеревятником.

Различными авторами в Великобритании были премлокены буферные зоны вокруг гнёзд осоела ралиусом 250-600 м (Currie, Elliott, 1997) и 400-500 м (Petty, 1998). В Венгрии мия осоела премлагается бусерная зона радиусом 100 м (3,14 га) от гнезда с запретом любых продолжительных нарушений и 200 м (12,56 га) - с запретом беспокойства в периол с 15 апреля по 31 августа (Pongracz, Horvath, 2010). В Украине мия осоела премложена бусерная зона, искиючающая рубки, в рахиусе не менее 300 м от гнезда (Витер, 2014).

В Красной книге Аитайского края прописано требование вылелять в радиусе 200 м вокруг гнёзА хохиатых осоедов киючевые биотопы с последуюшим утвержлением их в качестве особо зашитных участков леса с запретом любых рубок, причём как в заказниках, так и вне ООПТ (Рыљков, 2016).

Согласно нашим исследованиям, обоснованный радиус бусерной зоны вокруг гнезда осоела должен быть не менее 90 м (табл. 5), в оптимальном варианте - 180 м. Аия стандартизации размеров бусерных зон мия видов, имеюших гнёзда размером от 0,4 ло 1 м, необходимо придерживаться рахиуса 300 м, с определёнными послаблениями в режиме (выборочные рубки и рубки ухода) вне гнездового периода в зоне от 180 мо 300 м, если иное не установлено в региональных Красных книгах (см., например, Рыжков, 2016). Аия территории заказников, в первоочередных целях которых стоит не эксплуатация лесов, а сохранение биоразнообразия, име-
Гнездо осоеда с птенцами (Новосибирская область). Фото И. Карякина.

Nest of the Honey Buzzard with nestlings (Novosibirsk region). Photo by I. Karyakin.

ет смысл ограничивать ^юбые рубки в радиусе 250 м вокруг гнёзд осоедов, так как это улучшит конкурентные позиции этого вида в условиях совместного обитания с тетеревятником.

\section{Ястреб-тетеревятник (Accipiter gentilis)}

Тетеревятник в настояшее время является Аостаточно обычным гнездяшимся виАом лесной и лесостепной зоны Евразии. Его неблагополучный статус в ряле стран Европы был вызван преследованием со стороны человека в середине XX столетия (Kenward, 2006), однако негативное влияние рубок леса на гнездовых участках тетеревятников на распределение и численность этого вида тоже было отмечено в США, Нилерландах, Аании и ряле других стран (Bijleveld, 1974, Bezzel et al. 1997; Bijlsma, 1999; Drachmann, Nielsen, 2002; Squires, Kennedy, 2006). Аия стран Фенноскандии важным фактором, способствовавшим сокрашению численности вила, считалось изменение практики лесоводства - переход от выборочных рубок к сплошным (Forsman, Ehrnsten, 1985; Widen, 1997; Saga, Selas, 2012). Хотя в последнее время положительные взаимосвязи межАу плотностью распределения на гнездовании тетеревятников и площаАью старого леса, как во времени (Widen, 1997), так и в пространстве (Selas et al., 2008), соотносят, главным образом, с важностью старого леса мия базовых жертв ястреба ими его охотничьих возможностей в таком лесу, а не с чувствительностью вила к изменению его гнездовых местообитаний (Widen, 1989; Tornberg, Colpaert, 2001; Greenwald et al., 2005), рубки всё же остаются важным негативным фактором мля этого ястреба. При этом Ао сих пор остаётся неясным влияние фрактора беспокойства на тетеревятника, учитывая его скрытность и терпимость к присутствию мюдей на гнездовых участках.

В Северной Америке и Евразии тетеревятник ахаптируется к изменению человеком его местообитаний и при отсутствии его целенаправленного преследования терпим к определённой деятельности чемовека, наблюдается его вселение в городские местообитания (Карякин, 1998; Аруп, 

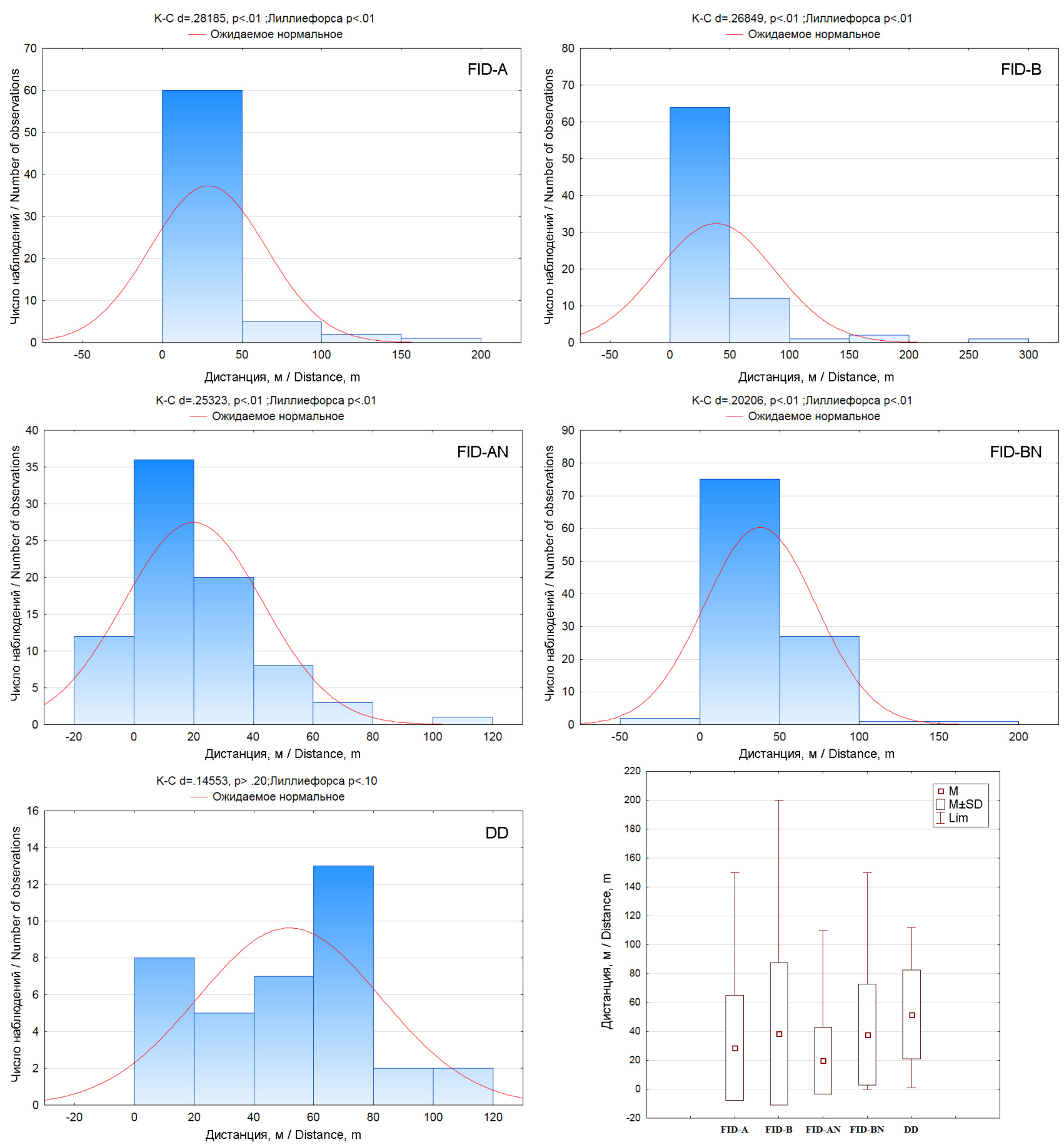

Pис. 18. Аистанции вспугивания (FID) тетеревятника (Accipiter gentilis): FID-A - Ао птицы на присаце в период насиживания яиц, FID-B - $\Delta$ п птицы на присаце в период выкарммивания птенцов, FID-AN - АО птицы на гнезде в период насиживания яиц, FID-BN - $\triangle$ п птицы на гнезде в период выкармиивания птенцов; DD - дистанции от гнёзд тетеревятника, АО края зоны нарушений, на которых гнёзда бросаются птицами.

Fig. 18. Flight initiation distances (FID) for the Goshawk (Accipiter gentilis): FID-A - for a bird on a perch during incubation period, FID-B - for a bird on perch during the nestling-rearing period, FID-AN - for a bird in a nest during incubation period, FID-BN - for a bird in a nest during the nestling-rearing period; DD - distances from abandoned nests of the Goshawk to the edge of the disturbances zones.

2002; Аруп, Ильюх, 2003; Апарова, 2003; Rutz et al., 2006; Храбрый, 2012; Камякин и Ар., 2014), гАе продуктивность гнездяшихся пар даже выше, чем в сельской местности (Solonen, 2008), а также расселение по лесополосам в степной зоне Украины и юга Европейской части России (Белик,
2003; Мороз, Кондратенко, 2003; Пилипенко, 2003; Рединов, 2003). Городские тетеревятники на редкость терпимы к человеческой деятельности, используют Аля охоты антропогенные структуры и строения (Rutz, 2004) и позволяют приближаться к ним на 10 м (Rutz, 2003) или же во- 


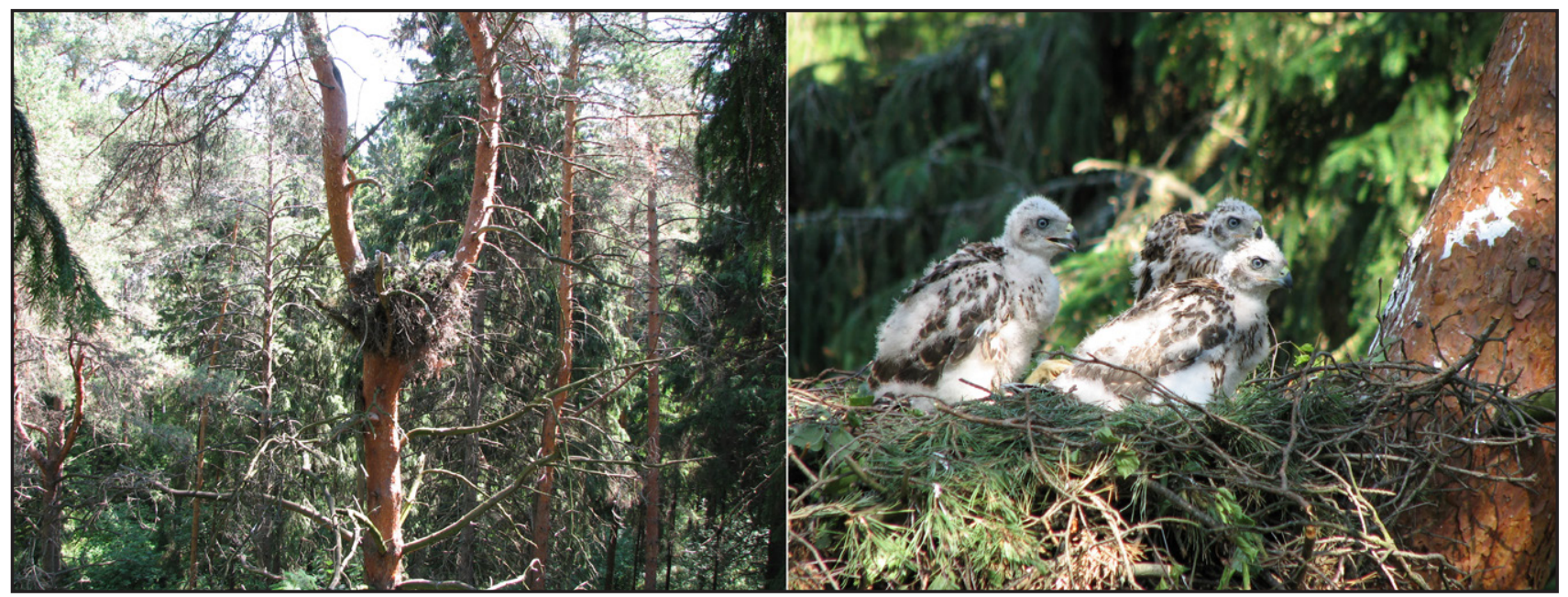

Гнездо тетеревятника с птенцами.

Фото А. Левашкина.

Nest of the Goshawk with nestlings.

Photo by A. Levashkin. обше не покидают гнёзда при проходе под ними Аюдей, и Ааже если по гнездовому Аереву стучать палкой (Апарова, 2003). Но такая толерантность, проявляемая городскими парами, не является обычным явлением в сельской местности, хотя и там похожие случаи наблюдаяи, но редко (Rutz et al., 2006). К сожамению, процесс ацаптации тетеревятников к человеческой деятельности идёт не везде. В частности в Великобритании тетеревятник избегает человеческого жилья и автодорог, гнезАясь на расстояниях более 200 м от них (Petty 1996). Аналогичным образом выгляАит ситуация во многих регионах Сибири.

Аяя негнездяшихся тетеревятников в $\Delta \mathrm{a}-$ нии FID при беспокойстве пешеходом определены в 102-124 м, в среднем 111 м $(n=3)$ (Bijlsma, 2008). В Великобритании по результатам опроса специаиистов AD в период киалки определена в среднем 198 м (медиана 125 м, интерваи - 10-500 м), в период выкармиивания птенцов - 218 м (медиана 175 м, интерваи - 50-500 м), FID - в период киацки определена в среднем 103 м (медиана 30 м, интерваи - <10-500 м), в перио выкармиивания птенцов - 137 м (медиана 75 м, интерваи - 10-300 м) (Ruddock, Whitfield, 2007). В России в естественных лесных сообшествах взросыые тетеревятники заранее покидают гнезАо при приближении наблюдателя на 100-250 м (наблюдения B.М. Гачушина, А.В. Кузнецова, М.С. Романова и В.И. Воронецкого на Верхнем Аону, в Аарвинском и Брянском заповедниках и на Звенигородской биостанции в Подмосковье), но в городских лесопарках поведение тетеревятника меняется радикаиьно - птицы не покидают гнездо Ааже при их активном беспокойстве (Апарова, 2003)

По нашим данным (все наблюдения в естественных лесах, без учёта птиц в городских лесах, а также лесополосах в степных районах Поволжья) показатели FID мяя тетеревятников вне гнёзд в период выкармиивания птенцов составили в среднем $(n=80)$ 38,5 $\pm 49,27$ (2-300 м, медиана - 20 м, мода - 10 м), в период насиживания яиц - $(n=68)$ 28,99 $\pm 36,34$ (3-200 м, медиана - 15 м, мода - 30 м) (рис. 18). $\triangle$ истанция вспугивания птиц с гнёзд в период киахки составила $(n=80) 19,94 \pm 23,21$ (0-110 м, медиана - 8 м, мода - 0 м), в период выкармиивания птенцов - $(n=106)$

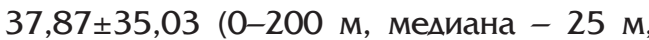
мода - 20 м). Не взлетели при проходе наблюдателей под гнездом $15 \%$ птиц на киалках из 80, а 40 \% взлетели с Аистанции менее 10 м; с гнёзд с птенцами не взлетели 1,89\% птиц из 106 при проходе под гнезАом, а 19,81 \% птиц покинули гнёзда с Аистанции менее $10 \mathrm{~m}$.

Средняя дистанция от гнезда тетеревятника $А$ края зоны нарушений, на которой гнездо осталось жилым, составляет $(n=6)$ 84,33 23,86 м (50-105 м), при средней Аистанции DD, на которой гнёзда оказаиись брошенными - $(n=37) 51,84 \pm 30,65$ м, от 1 Ао 112 м (рис. 18). Сушественной разниць от типа нарушений незамечено из-за явной нехватки Аанных по влиянию сплошных рубок и линейных нарушений. Тетеревятники бросили гнёзда в 10, 44 и 70 м от края сплошной рубки (41,33 $\pm 30,09$ м), при этом одно гнездо в 58 м от края спмошной рубки, плошацью более $1 \mathrm{kм}^{2}$, проведённой осенью, оказамось жилым на следуюший год после рубки. Аналогичная ситуация наблюдаяась с реакцией на минейные объекты (ЛЭП и противопожарные разрывы) оказамись брошенными гнёзда в 35, 38 и 55 м от края нарушения, но жилым было гнездо в 50 м от края противопожарного разрыва (причём когАа его рубили, птиць сидели на кладке). Аистанции до края выборочных рубок, на которых гнёзда были 


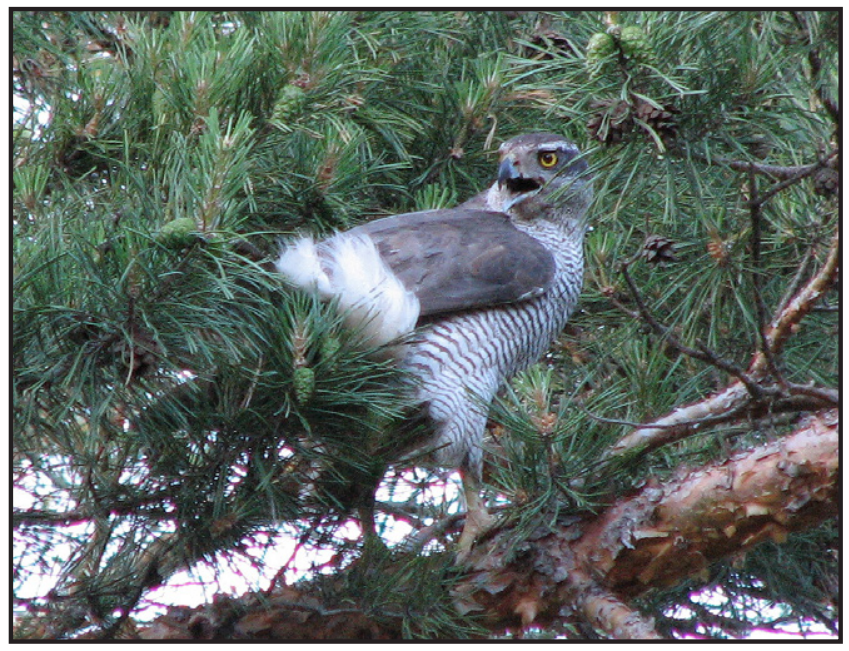

Тетеревятник. Фото А. Левашкина.

Goshawk.

Photo by A. Levashkin. брошены птицами, варьировами от 1 Ао 112 м, составив в среднем 53,74 $\pm 32,19$ м, но при этом 4 гнезАа оказались жилыми на Аистанциях 95-105 метров (99,5 $\pm 4,20$ м).

Различными авторами были предложены буферные зоны вокруг гнёзА тетеревятника ралиусом 250-450 м (Currie, Elliott, 1997), 400 м (Petty, 1996; 1998; Penteriani, Faivre, 2001; Richter, 2005), 400-500 м (Jones, 1979). При этом ммя лесохозяйственных предприятий Великобритании была премложена возможность сокрашения буфера $\Delta$ о 300 м спустя 10 Аней после вылупления птенцов и $о$ 200 м после их вылета из гнезда, с оговоркой, что уменьшение размера буфера возможно после оценки терпимости конкретных птиц к беспокойству на их участках и статуса тетеревятника на данной террииории (Petty, 1996). Стоит отметить, что месозаготовительная деятельность в пределах 50-100 м от гнезда тетеревятника может привести к тому, что птицы бросят его, Ааже при птенцах в возрасте 20 нней, что отмечено в США (Reynolds et al., 1992; Squires, Reynolds, 1997). С. Витер (2014) премложил мия тетеревятника в Украине бусрерную зону не менее 200 м.

Согласно нашим исследованиям, обоснованный радиус буферной зоны вокруг гнезда тетеревятника, устроенного в естественном лесонасаждении, Аолжен быть не менее 81 м (табл. 5), в оптимальном варианте - 162 м. Аия стандартизации размеров буферных зон мия видов, имеюших гнёзда размером от 0,4 $\Delta$ о $1 \mathrm{~m}$, необходимо придерживаться рациуса 300 м, с определёнными послаблениями в режиме (выборочные рубки и рубки ухода) вне гнездового периода в зоне от 160 о 300 м. ОАнако, эти параметры, возможно, подходят не мля всех типов леса. Так как наши основные исследования проведены в борах и смешанных лесах степной, лесостепной и юга лесной зон, то премложенные параметры для вылеления буферных зон вокруг гнёзд тетеревятника следует с осторожностью применять в средней и северной тайге и горно-таёжных лесах умеренной зоны.

В Норвегии лесозаготовки запрешены в ралиусе 50 м вокруг гнёзд тетеревятника (это приблизительно 0,8 га), при этом не разрешено оставлять вылел с гнезАом в виде изолированного участка при сплошной рубке (Saga, Selas, 2012). В рамках исследования в юго-восточной Норвегии, в ходе которого изучалось повторное использование гнёзд тетеревятниками (на 31 гнездовом участке) после заготовки Аревесины в 50 м от них, Аоля гнёзА, использованных во втором или третьем сезоне размножения после рубок (55 \%), сушественно не отличалась от Аоли контрольных гнёзА, хотя и была меньше, но было показано, что повторно используемые гнёзда отличались от тех, которые не использовались, тем, что были устроены в больших по плошахи участках старого леса и в лесах с большей Аолей ели (Picea abies), которая обеспечивает лучшее укрытие гнёзд, чем сосна (Pinus silvestris) и лиственные деревья (Saga, Selas, 2012). Авторы предположили, что более высокая доля гнездовых территорий с регулярно занимаемыми гнёздами, расположенными на елях, связана с тем, что в еловых лесах нет альтернативных мест мяя гнездования из-за более интенсивных рубок, нежели в гих типах леса. Слеловательно, толерантность тетеревятников к лесозаготовкам в еловых лесах может быть переоценена. Чтобы увеличить вероятность повторного использования гнёзд ястребами, авторы рекомендовами сохранять участки старого леса вокруг гнёзд на плошади не менее 2 га, что в 2,5 раза больше утверждённых параметров. Тяготение тетеревятника к гнездованию в более старых участках леса, особенно темнохвойного, мибо смешанного леса с более старыми темнохвойными деревьями, отмечена в разных странах Европы (Selas, 1997; Penteriani, 2002; Finn et al., 2002; Lohmus, 2005; Squires, Kennedy, 2006; Tornberg et al., 2006; Selas et al., 2008; Björklund et al., 2015) и в Японии, гАе ястребы предпочитали устраивать гнёзда на японском кедре (Cryptomeria japonica) диаметром более 50 см на уровне груди (Natsukawa et al., 2017). В Аругом исследовании в Северной 
Карелии (Финляндия) не был обнаружен эффрект от рубок на занятость гнездовых участков тетеревятников, если эти рубки происходили на дистанции 100 м и более от гнёзд, но были обнаружены при более близких к гнёздам дистанциях (Santangeli et al., 2012). Терпимость тетеревятника к рубкам, изменяюшим не более чем на $30 \%$ структуру леса на их гнездовых участках, отмечена в центрамьной Итамии и восточной Франции (Penteriani, Faivre, 2001).

Аля тетеревятника, обитаюшего на большей части лесной зоны, видимо, сохранение даже достаточно больших бусерных зон вокруг гнёзА - это полумера, так как вих сильно зависит от изменений, происходящих в плотности распределения видов-жертв, и если их плотность распределения снижается в результате рубок, при отсутствии Аоступных альтернативных кормов, таких как голуби и врановые, тетеревятник будет покидать участки, пусть они и не были затронуты рубкой. В частности, Р. РейнольАС мля сохранения тетеревятника предложил вылелять гнездовой участок в размере 8,1-10,2 га, который не рубится и не изолируется в ходе лесопользования от остальной части гнезАовой территории. Он также предложил, чтобы у кажАой

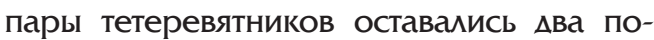
тенциально активных и Ава запасных места м^я устройства гнёзд, не пройденные рубками. Он рекомендовац, чтобы рубка $л е-$ ревьев (вкюючая прореживание) не велась ни на территориях активных гнёзд, ни на запасных территориях, поскольку это может уменьшить их привлекательность в качестве мест гнездования (Reynolds, 1983). Исследование, проведённое ешё в первой половине 80-х гг. в США на плато Кайбаб, что находится к северу от Национаиьного парка Гранд-Каньон, показамо, что вне за-

(Republic of Tatarstan). Photo by

R. Bekmansurov.

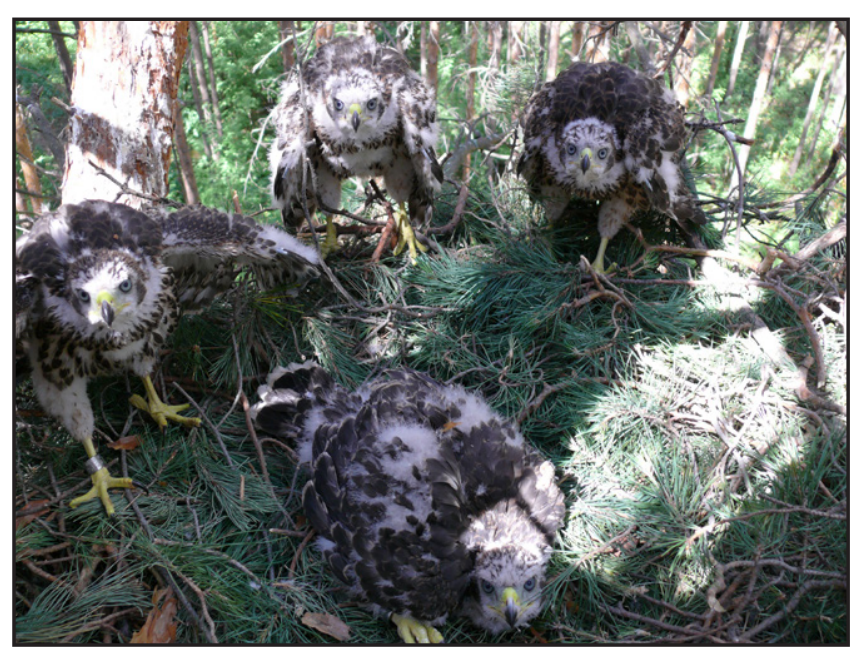

висимости от размеров буферных зон вокруг гнёзд (мамые бусеры от 1,2 $\Delta$ о 2,4 га и большие бусеры от 16 Ао 200 га) после проведения рубок, в ходе которых была

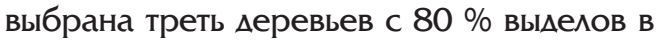
местах гнездования тетеревятника, занятость гнёзд упаиа на $80 \%$, а продуктивность на 94 \% (Crocker-Bedford, 1990). На основании своих исследований, автор рекомендоваи избегать ^есозаготовок на всей гнезАовой территории пары тетеревятников, тем самым увеличивая пиошадь гнездового бусера с 8,1 га Ао 1619-2023 га. В 1992 г. были выпушены "Рекомендации по сохранению северного тетеревятника на юго-запаце Соединенных Штатов" (Reynolds et al., 1992), которые были разработаны мля сосновых, смешанных хвойных и елово-пихтовых лесов. Эти рекомендации направлены на обеспечение оптимамьной среды обитания тетеревятников в гнездовой период, а также 14-ти его основных видов Аобычи. Вкратце, этот план рекомендует: 1) отсутствие рубок на трёх участках (гнездовом и Авух альтернативных, по 12,1 га кажАый) мия каждой гнездовой территории; 2) вылеление Аополнительных участков в пределах каждой гнездовой территории пары мия будушего использования тетеревятниками; 3) ротацию лесозаготовительных работ на территории послегнездового разлёта птенцов (170 га) и на охотничьей территории ястребов (2185 га), всегАа сохраняюшей минимум 60 \% поздне-сукцессионных лесов (киасс бонитета 31-46 см, 46-62 см и >62 cм); 4) ограничение сезона рубок на гнездовых участках и территории послегнездового разлёта птенцов с октября по февраль; 5) "оголение" в ходе рубок 0,4-1,6 га в зависимости от типа леса; и 6) сохранение резервных деревьев (1,2-2,4 шт./га), купола леса, плотностью (0,8-1,2/га), упавших и/или срубленных стволов деревьев (1,2-2,0 шт./га) и валежа (11,2-13,6 тонн/га) в зависимости от типа леса во всех районах, в которых ведутся рубки.

В недавно опубликованном обзоре американских исследователей было показано, что рубки и размер деревьев вблизи гнёзд тетеревятника объясняют вариации в занятости гнездовых участков, но не продуктивности пар, и однозначность влияния рубок на те или иные стороны экологии во всех современных исследованиях не очевидна (Rodriguez et al., 2016). Поэтому при планировании охраны тетеревятника в активно осваиваемых рубками лесах, особенно сосновых (возможно и миственничных) и 
лиственных, где вид более уязвим к изменению структуры леса на гнездовых участках, следует продумывать более сложную систему управления лесопользованием, опираясь на рекомендации Р. Рейнольдса с соавторами (Reynolds et al., 1992; Youtz et al., 2008).

Ястребы-перепелятники обыкновенный и мамый (Accipiter nisus, A. gularis)

Ястреб-перепелятник - обычный виА, населяюший всю лесную зону Евразии, в России в основном мигрант, но на большей части Европы обитает круглогодично (Newton, 1986), в ряде городов Европы гнездится с высокой плотностью, например, в Праге городские перепелятники гнездились даже с более высокой плотностью, чем в окружаюших лесах, в среднем 1 пара / 600 га, локаиьно до 1 пары / 150210 га / (Peške, 1987, 1999).

Мамый перепелятник, в отличие от обыкновенного, гнездится на куда более скромной по площали территории, ограниченной югом Восточной Сибири и Аальнего Востока, северо-востоком Китая, Корейским полуостровом и Японией, обычен мишь в хвойно-широколиственных лесах восточной части своего гнездового ареала (на запал до бассейна Амура) (Brazil, 2009).

Несмотря на обычность обыкновенного перепелятника и многочисленность исслеАований по этому виду в Европе, работ, направленных на ответ вила на беспокойство и нарушения на гнездовых участках крайне мамо, а по мамому перепелятнику таких исследований нам и вовсе не удаАось обнаружить.

Ая негнездяшихся перепелятников в $\Delta а-$ нии FID при беспокойстве пешеходом определены в 35-134 м, в среднем 75 м $(n=14)$ (Bijlsma, 2008). Во Франции FID перепелятников, встреченных в сельской местности, составили в среднем (n=2) 10 м (Møller, Erritzøe, 2010), в зоне городской застройки в г. Орсе в пригороде Парижа средние показатели FID мля перепелятника наряду с Аругими городскими хишниками составили в среднем (M+SE) 54,08+1,47 м (Møller, 2012). В Чехии показатели FID перепелятников варьировали от 0 Ао 80 м (Mikula, 2014; Kunca, Yosef, 2016). В исследовании, проведённом в Праге (19 гнездовых участков) и в северной Чехии (17 гнезАовых участков), направленном на сравнение ответов перепелятников, гнездяшихся в городе и сельской местности, на беспокойство Аюдьми, показано, что нежемание покидать гнезАо и агрессивное по- ведение, было более частым в городских районах (84,6 \%), чем в сельских районах $(15,4 \%)$, что коррелирует с Аистанциями от гнёзд перепелятника $\Delta$ о Аорог и троп, которое составило в среднем 65,0 $\pm 59,94$ м в сельской местности и 33,6 29,95 м в городской местности. Была обнаружена тенденция к влиянию стадии размножения на поведение самок "пугливое" $\left(X^{2}=4,80\right.$, $D f=1, P=0,02)$ и "агрессивное" $\left(x^{2}=4,24\right.$, $D f=1, P=0,03)$. Самки более охотно покидаии гнездо (ответ первого типа) во время инкубации яиц $(65,0$ \%), чем при выводке $(35,0 \%)$. Самки отказывамись оставлять птенцов чаше, чем киахки $(57,7$ \% против 42,3\% соответственно) (Kunca, Yosef, 2016). В этом исследовании AD варьировани от 2 Ао 200 м, составив в среднем ( $n=72) 48,42 \pm 48,21 \mathrm{M}$, FID - от $0 \Delta \mathrm{O} 80 \mathrm{M}$, в среднем $11,03 \pm 17,36$ м: в период киалки $(n=36) 0-80$, в среднем $12,89 \pm 19,75$ м, в период выкармиивания выводков $(n=36)$ 0-50, в среднем 9,17 $\pm 14,63$ м (Kunca, Yosef, 2016: Data S1).

По результатам исследований в Чехии было установлено, что самки перепелятника, размножаюшиеся в городской среАе, проявляют большую степень агрессии, чем самки, гнездяшиеся в сельских районах (Kunca, Yosef, 2016). Не совсем ясно, является ли это снижение агрессии результатом преслеования более агрессивных и менее осторожных птиц Аюдьми, или же наоборот - повышенная агрессивность "город-

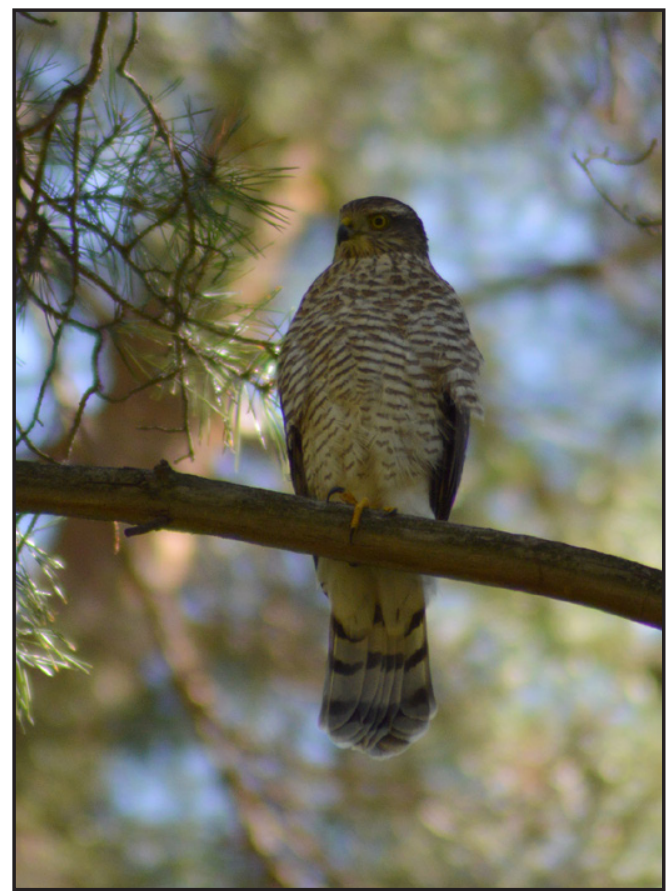

Перепелятник (Accipiter nisus). Фото И. Карякина. Sparrowhawk (Accipiter nisus). Photo by I. Karyakin. 

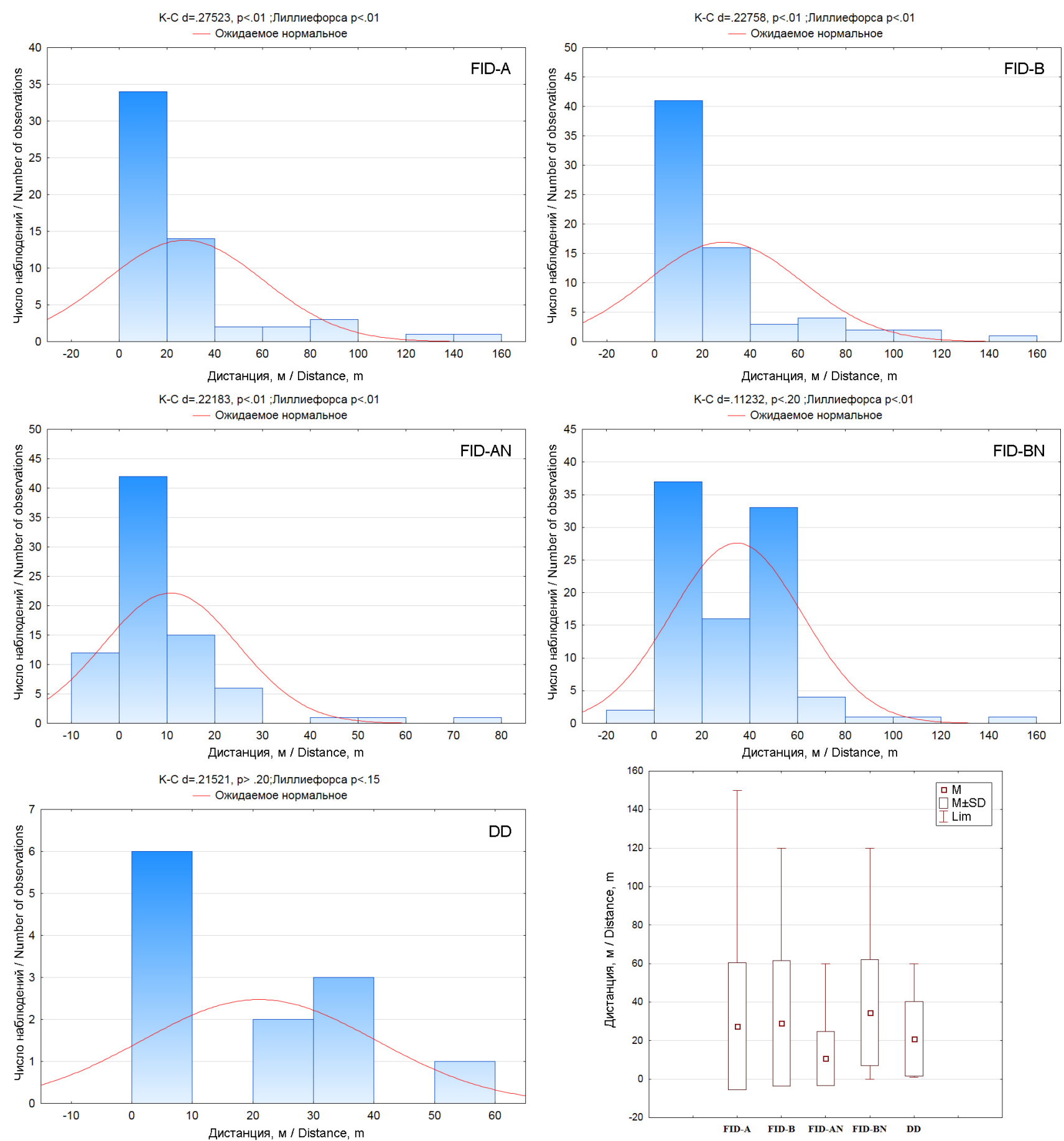

Рис. 19. Аистанции вспугивания (FID) перепелятника (Accipiter nisus): FID-A - $\Delta$ о птицы на присаце в период насиживания яиц, FID-B - $\Delta$ о птицы на присахе в период выкармливания птенцов, FID-AN - $\Delta$ птицы на гнезде в период насиживания яиц, FID-BN - $о$ птицы на гнезде в период выкармиивания птенцов; DD - дистанции от гнёзд перепелятника, до края зоны нарушений, на которых гнёзда бросаются птицами.

Fig. 19. Flight initiation distances (FID) for the Sparrowhawk (Accipiter nisus): FID-A - for a bird on a perch during incubation period, FID-B - for a bird on perch during the nestling-rearing period, FID-AN - for a bird in a nest during incubation period, FID-BN - for a bird in a nest during the nestling-rearing period; DD - distances from abandoned nests of the Sparrowhawk to the edge of the disturbances zones.

Ских" ястребов является следствием более частого беспокойства их ^юдьми. Так или иначе, похоже, что, несмотря на то, что перепелятники ацаптироваиись к жизни в городской среде, они не ацаптироваиись к беспокойству со стороны человека и не потеряли своих зашитных механизмов. Ре- зультаты исследований в Праге свидетельствуют о том, что городские пары ястребов постоянно испытывают более высокий уровень стресса, чем те, которые гнездятся в сельских районах (Kunca, Yosef, 2016).

В России перепелятник также гнездится в городах, хотя его освоение городских 
лесопарков, а тем более парков, идёт с меньшими темпами, нежели в Европе (Рахимов, 2001; Мельников, 2003; Москвичев и мр., 2011; Самойлов, Морозова, 2011; Храбрый, 2012). Тем не менее, Ааже здесь замечено, что в городской среде самки на гнёздах ведут себя более агрессивно и при беспокойстве кюАьми с меньшей охотой покидают гнёзда, нежели в лесах, удалённых от городов (Жимулёв и Ар., 2008).

По нашим Аанным (все в естественных лесах, без учёта птиц в городских лесах) показатели FID мяя перепелятников вне гнёзА в период выкармиивания птенцов составили в среднем ( $n=69) 29,06 \pm 35,52$ (1-160 м, медиана - 20 м, мода - 30 м), в период насиживания яиц - $(n=57)$

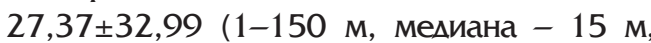
мода - 30 м) (рис. 19). Аистанция вспугивания птиц с гнёзА в период киалки составила (n=78) 10,76 $\pm 14,04$ (0-80 м, медиана - 5 м, мода - 0 м), в период выкармиивания птенцов - ( $n=106) 34,55 \pm 27,47$ (0-150 м, медиана - 30 м, мода - 50 м). Не взлетели при проходе наблюдателей под гнездом 15,38 \% птиц на киакках из 78, а 46,15 \% взлетели с Аистанции менее 10 м, с гнёзд с птенцами не взлетели 1,89 \% птиц из 106 при проходе пол гнезАом, а 18,87 \% птиц покинули гнёзда с дистанции менее 10 м. Несмотря на меньший размерный киасс, реакции перепелятника на беспокойство мюдьми были аналогичны таковым тетеревятника, что, возможно, указывает на то, что оба вида на территориях наших исследований испытывают более или менее одинаковый пресс со стороны человека, в противоположность Европе, гле перепелятник более терпим к беспокойству (см., например Kunca, Yosef, 2016).

Средняя дистанция от гнезда перепелятника $\Delta$ края зоны нарушений, на которой гнездо осталось жилым, составляет $(n=4)$

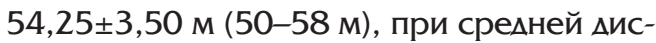



танции DD, на которой гнёзда оказались брошенными - $(n=12) 21,0 \pm 19,34$ м, от 1 $\triangle 060$ м (рис. 19).

В Великобритании премложены бусерные зоны вокруг гнёзд перепелятника радиусом 80-125 м (Petty, 1998). С. Витер (2014) прецложил мяя перепелятника в Украине бусерную зону не менее 200 м.

мия малого перепелятника в Красной книге Алтайского края прописано требование в случае обнаружения гнездовых участков вида на территории заказников вылелять киючевые биотопы с последуюшим созданием особо зашитных участков леса с полным прекрашением в них мюбых видов деятельности, ведуших к гибели гнезда (оставлению его птицами) или разрушению среды обитания (любых рубок леса; работ, связанных с разведкой и добычей полезных ископаемых; пребывания людей, веАушего к беспокойству птиц). Вокруг гнёзА вне территорий ООПТ также Аолжны вылеляться буферные зоны радиусом 200 м от гнезда с искююением на них мюбых рубок в Аюбое время года и всех видов деятельности, ведуших к прекрашению сушествования гнездового участка (Ирисова, 2016а).

Согласно нашим исследованиям, обоснованный рациус бусрерной зоны вокруг гнёзА перепелятников обоих видов, устроенных в естественных лесонасажлениях за пределами городских лесов, Аолжен быть не менее 55 м (табл. 5), в оптиманьном варианте -110 м. Аия стандартизации размеров бусерных зон мия видов, имеюших гнёзда размером до 0,4 м, необходимо придерживаться радиуса 150 м, с определёнными послаблениями в режиме (выборочные рубки и рубки ухода) вне гнездового периода в зоне от 110 Ао 150 м, есии иное не установлено в регионаиьных Красных книгах (см., например, Ирисова, 2016а).

\section{Бамобан (Falco cherrug)}

Балобан - один из наиболее угрожаемых крупных соколов Евразии, стремительно сокративший свою численность в последние Аесятилетия, в основном по причине нелегаиьного лова мия нужА соколиной охоты и гибели на АЭП (Ковач и Ар., 2014). В лесостепной зоне России и Северного Казахстана от Подмосковья $\Delta о$ Ааурии балобан гнездился на деревьях в постройках Аругих хишных птиц и ворона (Corvus corax) и, как следствие, страцаи от лесозаготовок. В настояшее время в России фактически все Аревесногнездяшиеся популяции бамобана находятся на грани исчезновения, отдельные пары с этим сте- 
Балобаны

(Falco cherrug). Фото И. Карякина.

Saker Falcons

(Falco cherrug).

Photo by I. Karyakin

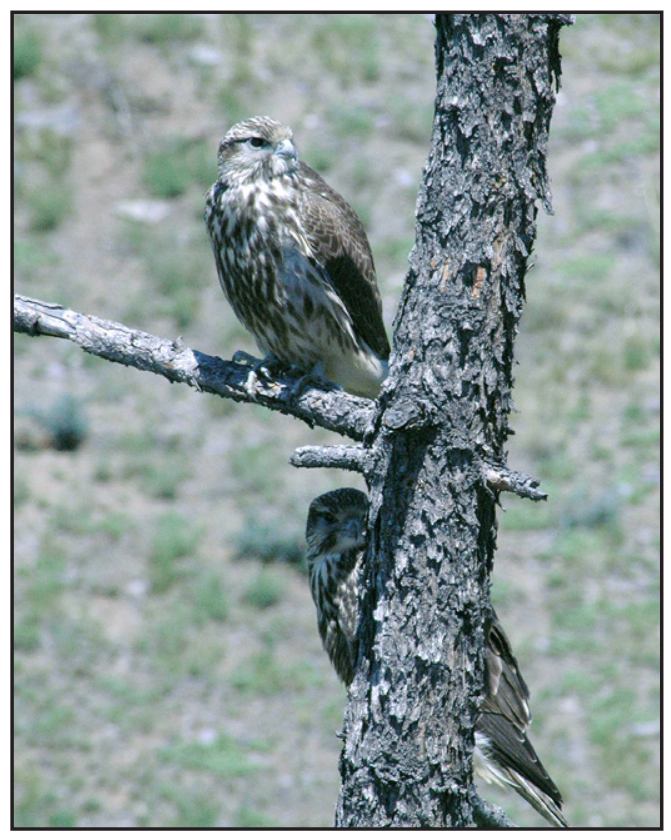

реотипом продолжают размножаться в Тобольских и Аитайских борах, в котловинах Аитае-Саянского региона, в Байкаиьском регионе и Ааурии (Карякин и Ар., 2015b), поэтому лесозаготовки в зоне гнездования этого виАа являются серьёзной угрозой выживания соколов, как в части разрушения местообитаний и элиминации гнезАового фонда, так и в части беспокойства во время лесохозяйственных мероприятий.

К сожалению, крайне сложно отследить непосредственное влияние рубок леса на занятость гнёзд балобана, так как соколы регулярно их меняют даже в условиях минимального преследования со стороны человека. Поэтому в нашем анализе представлены только те гнёзда, которые попали в зону рубок в гнездовой периол, когла можно было оАнозначно идентифицировать их занятость до момента проведения рубки - т.е. брошенные гнёзда идентисрицированы по погибшим киалкам и выводкам. Средняя Аистанция от гнезда балобана $\Delta$ края зоны нарушений, на которой гнездо оказалось брошенным соколами, составляет в среднем $(n=6) 47,83 \pm 22,60$ м, от 12 о 82 м (рис. 20). В зоне $\Delta$ о 100 м от края рубки было обнаружено единственное жилое гнездо с птенцами - оно нахоАилось в 80 м от края выборочной рубки, которая велась, когла в гнезде находились птенцы в возрасте 20-25 дней. Аалее 100 м от рубки в пределах километровой зоны было обнаружено 4 жилых гнезда.

Публикаций с описанием реакций балобанов на беспокойство со стороны человека, выражаюшихся в Аистанциях беспокойства или вспугивания, нам найти не удаиось.
По нашим данным показатели FID мяя Аревесногнездяшихся балобанов вне гнёзА в период выкармливания птенцов составили в среднем $(n=33) 112,42 \pm 72,06$ (5-280 м), в период насиживания яиц -

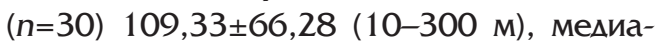
на - 100 м, мола - 80 м мя обоих периоАов (рис. 20). Аистанция вспугивания птиц С гнёзд в период киамки составияа $(n=44)$ $20,41 \pm 18,48$ (0-70 м, медиана и мода - 20 м), в период выкармиивания птенцов - $(n=49)$

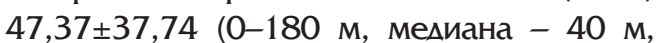
мода - 60 м). Не взлетели при проходе наблюдателей пол гнезАом 15,91 \% птиц на киалках из 44, а 13,64\% взлетели с $и$ итанции менее 10 м; с гнёзА с птенцами не взлетели 4,08 \% птиц из 49 при проходе под гнезАом, а 10,2 \% птиц покинули гнёзда с Аистанции менее 10 м. При приближении к гнёздам на автомобиле дистанции вспугивания были короче в 2 раза в оба периода, а

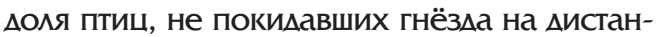
ции 10-50 м от гнездового дерева, увеличивалась в 3 раза. FID балобанов, гнездящихся на АЭП и скаиах мия целей данной работы мы не анаиизироваии.

Аия близкого вида - мексиканского сокола (Falco mexicanus) в Монтане средние показатели FID опрелелены в 79,0 58,7 м ( $n=86$, медиана - 63, прелел 75 \% вспугиваний - 90 м, $90 \%$ - 150 м, $95 \%$ - 200 м от гнезда) (Van Horn, 1993). Аия негнездящихся птиц FID при Авижении на автомобиле составила в среднем $(M \pm S E) 85 \pm 11$ м $(n=27$, диапазон - 18-200 м), при движении пешком - 92 8 м $(n=33$, миапазон 24-185 м), доля вспугиваемых птиц составила $78 \%$ и $91 \%$ соответственно (Holmes et al., 1993). Аия негнездяшихся сапсанов в Аании FID при беспокойстве пешеходом опрелелены в 135-272 м, в срелнем 208 м (n=3) (Bijlsma, 2008). В Великобритании по результатам опроса специаиистов мия гнезАяшихся сапсанов AD в период киалки определена в среднем 306 м (медиана 225 м, 80-процентный интервал - 10-750 м), в периол выкармливания птенцов - 354 м (медиана 312,5 м, 80-процентный интерваи 150-750 м), FID - в период киамки опрелелена в среднем 199 м (медиана 125 м, 80-процентный интерваи - 10-500 м), в период выкармиивания птенцов - 281 м (медиана 225 м, 80-процентный интервам - 50-500 м) (Ruddock, Whitfield, 2007).

В Венгрии мия балобана предлагается бусерная зона радиусом 50-100 м (0,8-3,14 га) с запретом мюбых проАолжительных нарушений и 200-400 м (12,56-50,24 га) - с запретом беспокой- 

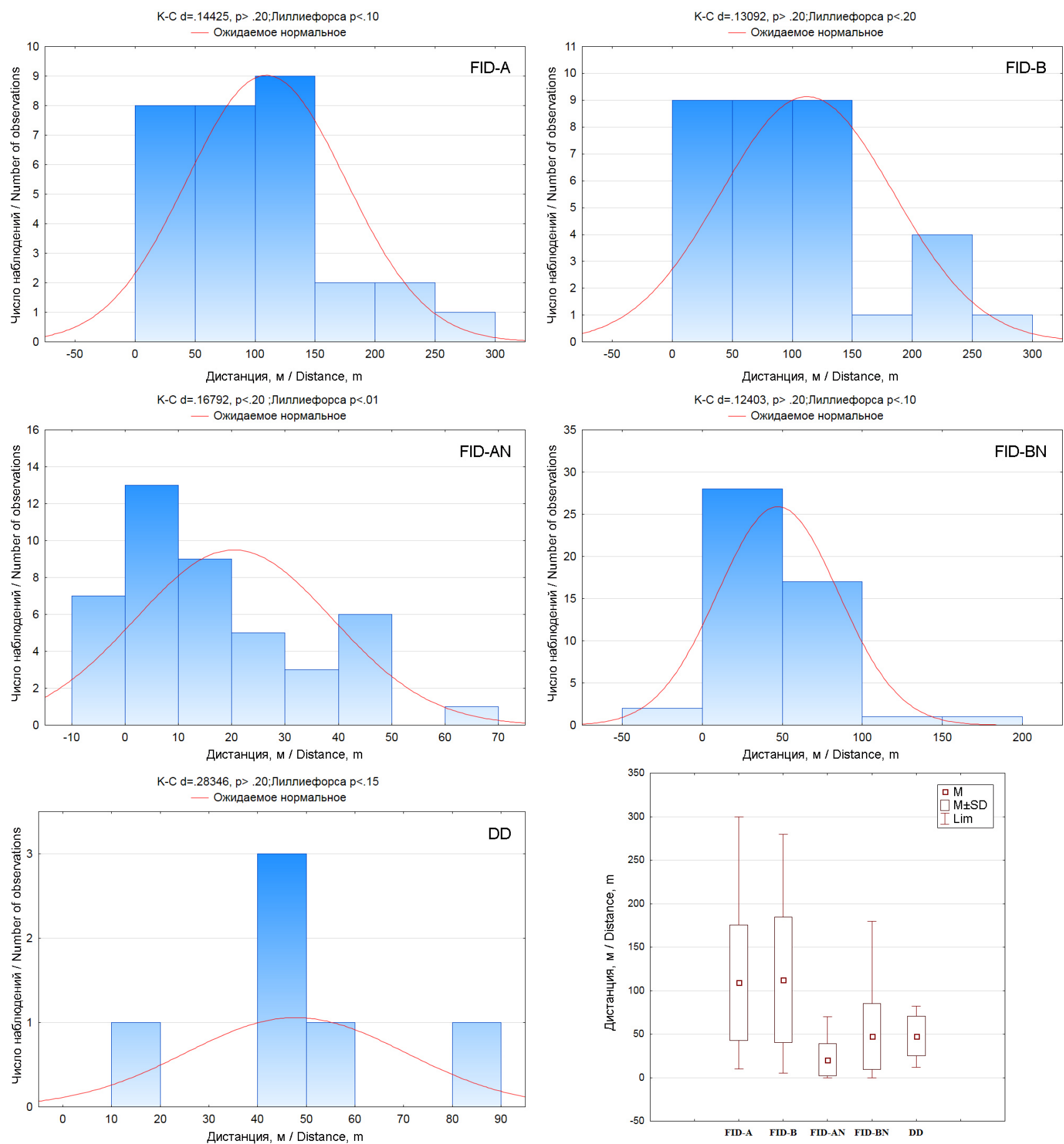

Рис. 20. Аистанции вспугивания (FID) балобана (Falco cherrug): FID-A - $\Delta$ п птицы на присаце в период насиживания яиц, FID-B - $\triangle$ о птицы на присаце в период выкармиивания птенцов, FID-AN - $\Delta$ птицы на гнезде в период насиживания яиц, FID-BN - $\Delta$ о птицы на гнезде в период выкармиивания птенцов; DD - дистанции от гнёзд балобана, Ао края зоны нарушений, на которых гнёзда бросаются птицами.

Fig. 20. Flight initiation distances (FID) for the Saker Falcon (Falco cherrug): FID-A - for a bird on a perch during incubation period, FID-B - for a bird on perch during the nestling-rearing period, FID-AN - for a bird in a nest during incubation period, FID-BN - for a bird in a nest during the nestling-rearing period; $D D$ - distances from abandoned nests of the Saker Falcon to the edge of the disturbances zones.

ства в период с 15 февраля по 15 июля (Pongracz, Horvath, 2010). В Ураиьском регионе мия охраны баиобана премлагалось регламентировать хозяйственную деятельность в радиусе 1 км от гнёзА соколов, мля чего следовало запрешать любое изменение ландшасрта (рубки, прокиацку трасс, разработку полезных ископаемых и т.А.), а так же ограничивать, вплоть $А$ полного запрета, любую хозяйственную деятельность, вкиючая выпас, в радиусе хотя бы 100 м от гнезда, но с обязательным сохранением сложившегося типа природопользования на охотничьем участке птиц, вкиючая выпас 
и сушествуюшие летние лагеря скота далее 100 м от гнезда (Карякин, 1998).

мия мексиканского сокола, как собственно и мяя сапсана, в США и Канаде разными авторами предлагается вылеление бусерных зон вокруг гнёзд, в основном радиусом 800 м, хотя премложены и крайние варианты от 50 Ао 1500-1600 м, основанные на реакциях птиц на разные типы беспокойства (Richardson, Miller, 1997). В Канаце, государственными рекомендациями, утвержАёнными в 1987 г., закрепиена необходимость закрывать сушествуюшие тропы, Аороги и места отдыха в пределах от 0,6 $\Delta$ о 0,8 км от мест расположения гнёзА сапсанов и не строить новых Аорог и мест отдыха в бусерной зоне, а в период размножения с 15 марта по 31 августа запрешать развлекательные мероприятия, такие как походы, пикники, магеря отдыха и охоту в прелелах от 0,6 Ао 0,8 км от гнёзА сапсана; бусерные зоны, в которых запрешается скаиолазание, езда на велосипедах или квацроцикиах, Аолжны быть рамиусом от 0,9 Ао 1,2 км (Peregrine Falcon..., 1987). В Великобритании рекомендованы охранные зоны вокруг гнёзд сапсана на лесных территориях, искиючающие рубки в рациусе 400-600 м (Petty, 1998) и 600-1000 м (Currie, Elliott, 1997).

В Красной книге Аитайского края закреплена необходимость строгой охраны известных гнездовых участков балобана с запретом рубок в местообитаниях вида в лесных массивах в ралиусе не менее 300 м от гнезАа, гле также Аолжно искиючаться ^юбое беспокойство в период гнездования. Также в Красной книге в качестве первоочередных мер по сохранению среды обитания бамобана в равнинной части края прописано требование выделять киючевые биотопы с последуюшим созданием особо зашитных участков леса (в первую очередь, на опушках менточных боров) с запретом рубок, а также вылелять зоны особой охраны в заказниках (Пиотников, 2016с).

Согласно нашим исследованиям, обоснованный рамиус буферной зоны вокруг гнезАа, занимаемого балобаном, Аолжен быть не менее 81 м (табл. 5), в оптимаиьном варианте 162 м. Так как в равнинных месах бамобаны занимают мяя размножения в основном постройки орла-могильника, устроенные на соснах (Bragin, 2001; Карякин, 2004; Карякин и Ар., 2005а; 2005b; 2005с; Левин и Ар., 2007; Карякин, 2012), которые в последствии снова могут быть заняты орлами, то мяя стандартизации размеров буферных зон мия видов, внесённых в Красную книгу РФ и имеющих крупные гнёзда (1 м и более), необходимо прилерживаться радиуса 500 м.

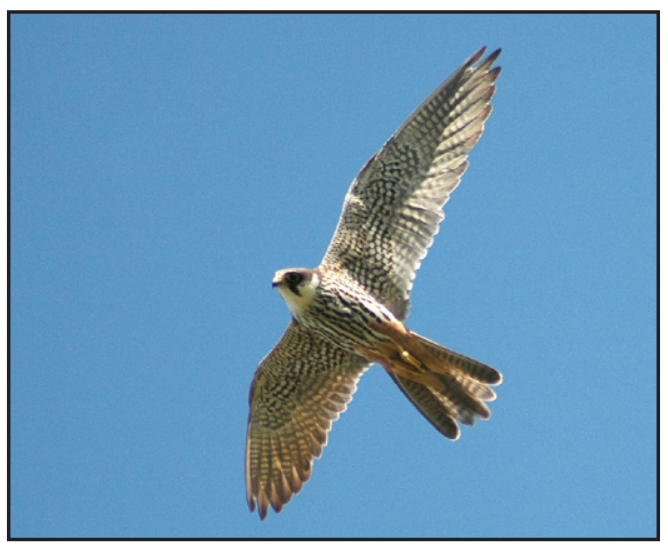

Чеглок (Falco subbuteo). Фото И. Карякина. Hobby (Falco subbuteo). Photo by I. Karyakin.

\section{Чеглок (Falco subbuteo)}

Чеглок - обычный гнездяшийся виА лесостепной и лесной зоны Евразии, в последние десятилетия активно осваиваюший на гнездовании города и селитебные ландшасты Европы (Fiuczynski, 2017). В России, несмотря на проникновение в города (Храбрый, 2012) и вглубь степной зоны (Ленева, Аавыгора, 2006), чеглок всё же остаётся преимушественно видом естественных месных местообитаний, гАе предпочитает старые приречные леса, а также леса по берегам озёр.

Несмотря на свою обычность, публикации по ответу чеглока на беспокойство человека и нарушения, связанные с человеческой Аеятельностью, фактически отсутствуют. Какого-либо влияния лесохозяйственной Аеятельности на популяции чеглока не отмечено, в первую очередь по той причине, что вид занимает Аля гнездования Аостаточно узкие участки леса вАОль воАоёмов или по опушечной зоне, которые в большинстве своём являются зашитными лесами. Так как чеглок занимает в первую очередь гнёзда ворон (ики Аругих врановых) (Карякин, 1998; Probst, 2013; Fiuczynski, 2017), то не мимитирован неАостатком гнезАового фонда и/или возрастом деревьев.

По нашим Аанным показатели FID мия чеглоков вне гнёзд в период насиживания яиц составили в среднем ( $n=83) 53,18 \pm 36,18$ (1-160 м, медиана - 50 м, мода - 60 м), в период выкармиивания птенцов - $(n=65)$

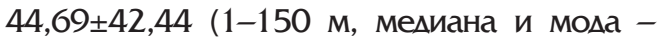
30 м) (рис. 21). Аистанция вспугивания птиц с гнёзд в период киамки составияа $(n=112)$ 16,38 $\pm 19,93$ (0-80 м, медиана - 8 м, мода О м), в период выкармиивания птенцов ( $n=140)$ 31,63 $\pm 20,48$ (0-110 м, медиана 30 м, мода - 40 м). Не взлетели при проходе наблюдателей под гнездом 13,39 \% птиц на 

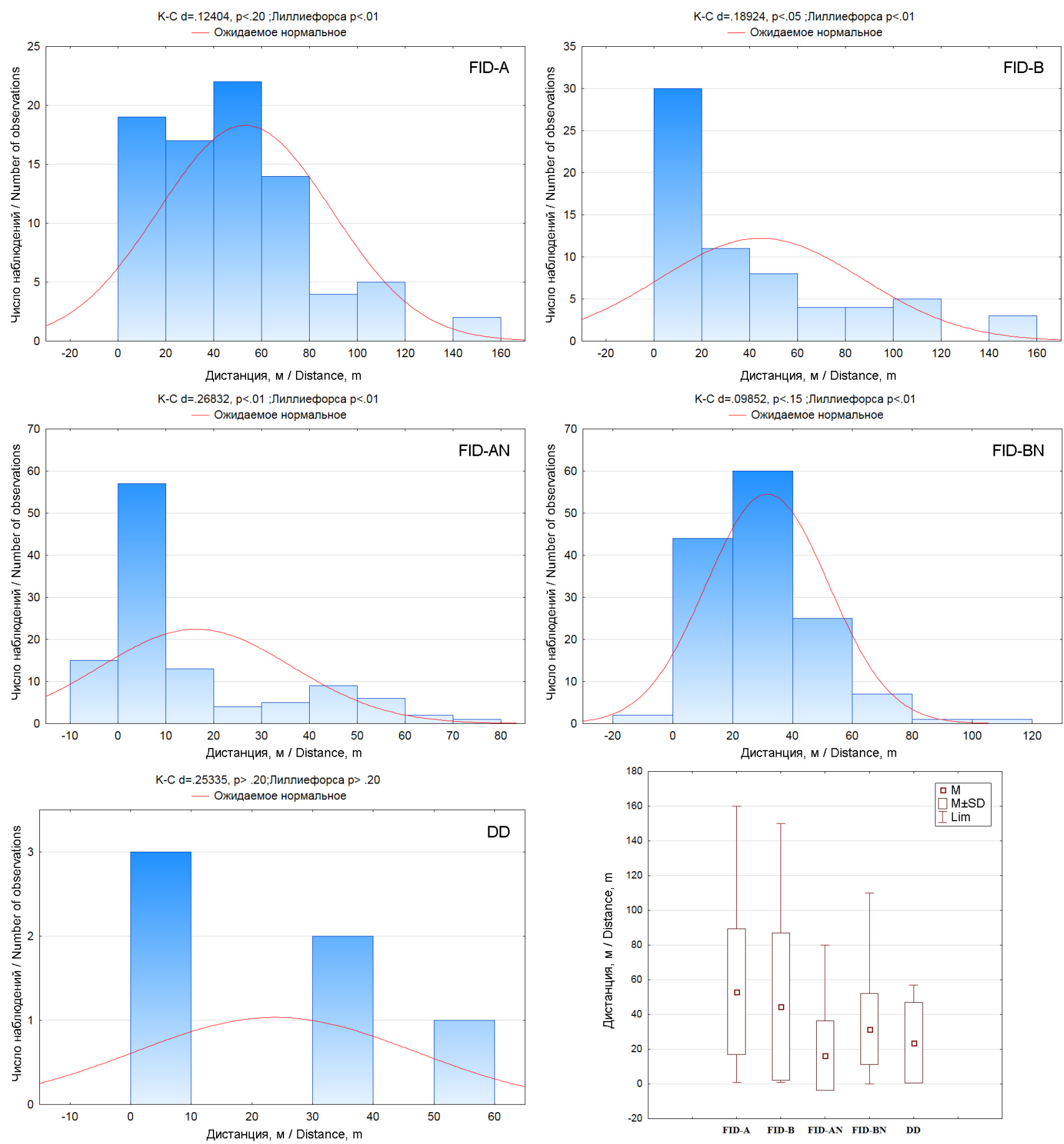

Рис. 21. Аистанции вспугивания (FID) чеглока (Falco subbuteo): FID-A - Ао птицы на присаце в период насиживания яиц, FID-B - $о$ о птицы на присаце в период выкармливания птенцов, FID-AN - $\Delta$ п птицы на гнезде в период насиживания яиц, FID-BN - $о$ птицы на гнезде в период выкармиивания птенцов; DD - дистанции от гнёзд чеглока, до края зоны нарушений, на которых гнёзда бросаются птицами.

Fig. 21. Flight initiation distances (FID) of the Hobby (Falco subbuteo): FID-A - to bird on perch in incubation period, FID-B - to bird on perch in nestling-rearing period, FID-AN - to bird in nest in incubation period, FID-BN - to bird in nest in nestling-rearing period; DD - distances from the nests of the Hobby to the edge of the disturbances zones in which the nests is abandoned by birds.

киалках из 112 , а 42,86 \% взлетели с Аистанции менее 10 м; с гнёзА с птенцами не взлетели 1,43\% птиц из 140 при проходе под гнезАом, а 15,0 \% птиц покинули гнёзда с Аистанции менее 10 м. Стоит отметить, что при активной реакции чеглоков при птенцах (крики, имитация атак) они доста- точно быстро успокаиваются и уже через 30 мин. - 1,5 часа не обрашают внимания на людей, которые находятся даиее 30 м от их гнёзд. На терпимость чеглоков к отдыхаюшим также обрашами внимание исслеАователи в Оренбургской области (Ленева, $\triangle$ авыгора, 2006). 


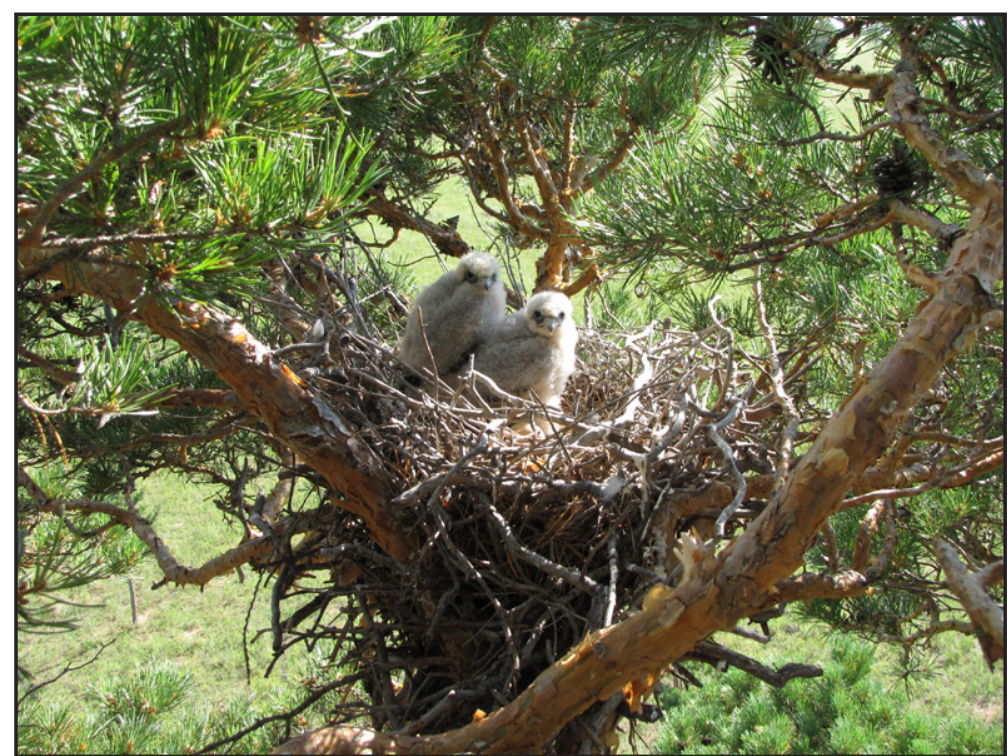

Птенцы чеглока в гнезде, устроенном на сосне в постройке чёрной вороны (Corvus corone).

Фото И. Карякина

Nestlings of the Hobby in the nest constructed by Oriental Crow (Corvus corone) on the pine tree.

Photo by I. Karyakin.
Средняя дистанция от гнезда чеглока $А$ края зоны нарушений, на которой гнездо осталось жилым, составляет $(n=2)$

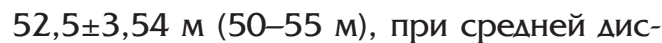
танции DD, на которой гнёзда оказамись брошенными - $(n=6) 23,83 \pm 23,11$ м, от 1 Ао 57 м (рис. 21).

В Великобритании прелможены бусерные зоны вокруг гнёзд чеглока радиусом 200-500 м (Currie, Elliott, 1997).

Согласно нашим исследованиям, обоснованный рахиус бусерной зоны вокруг гнёзд чеглоков, устроенных в естественных лесонасажлениях за пределами городских лесов, Аолжен быть не менее 54 м (табл. 5), в оптимаиьном варианте - 108 м. Аия станАартизации размеров бусерных зон мия видов, имеюших гнёзда размером $А$ 0,4 м, необходимо придерживаться рахиуса 150 м, с определёнными послаблениями в режиме (выборочные рубки и рубки ухода) вне гнезАового периода в зоне от 108 Ао 150 м.

\section{Аербник (Falco columbarius)}

Аербник - обычный гнездяшийся виА лесной и лесотундровой зон Евразии, в лесостепи немногочислен (Морозов и Ар., 2013) и, вероятно, степной подвиА (F. c. pallidus), сокративший численность в XX столетии, заслуживает охраны на федерацьном уровне (Карякин, Николенко, 2009). Как и все мелкие соколы, дербник зависит от гнездового фонда, обеспечиваемого врановыми, преимушественно серой и чёрной воронами (Corvus cornix, C. corone) и в центральной части России не ограничен лимитом гнёзд и не зависит от возраста леса, так как охотно размножается в угнетённых Аревостоях опушечной зоны и в сильно фрагментированных лесах (Карякин, 1998; Карякин, Николенко, 2009). Аия Беларуси в качестве важных угроз, подорвавших численность вида, указываются весенне-летние пожары на верховых болотах и заброшенных торфоразработках (Ивановский, 2016). Анамогично, видимо, степные палы негативно сказываются на популяциях степного мербника. Пожары также указаны, как основная угроза мия дербников, населяюших прерии Северной Америки, но мия соколов, гнездяшихся в тайге, в качестве угрозы приводятся сплошные рубки (Becker, Ball, 1983), хотя отмечено, что в разных районах и при различной интенсивности рубок, они могут Аавать как пагубные, так и положительные эсфекты мля популяций дербника (Stephens, Anderson, 2002).

Также как перепелятник и чеглок, дербник имеет тенденцию к освоению лесопарковой зоны городов, особенно в Европейской части России (см., например Мельников, 2003). Отдельные пары, особенно гнездящиеся в степной зоне, Аостаточно толерантны к беспокойству, но это не относится к основной массе птиц, что наблюдается и в других частях ареала вида, в частности в Великобритании и Канаце (Becker, Ball, 1983; Haney, White, 1999), причём у пар, гнездяшихся на урбанизированных территориях и более толерантных к людям, как правило, выше репродуктивные показатели и успех размножения (Sodhi et al., 1992).

На зимовке в КолораАо при беспокойстве на автомобиле средние показатели FID мяя Аербников составили $62 \pm 12$ м $(n=10$, миапазон 44-85 м), пешком - 76 13 м ( $n=14$, Аиапазон 17-180 м), причём доля вспугиваний составила $30 \%$ и $100 \%$ соответственно (Holmes et al., 1993). В Великобритании по результатам опроса специаиистов мия гнездяшихся дербников AD в период киалки определена в среднем 242 м (медиана 225 м, 80-процентный интерваи - <10500 м), в период выкармиивания птенцов 299 м (медиана 400 м, 80-процентный интерваи - 10-500 м), FID - в период киахки определена в среднем 100 м (медиана 30 м, 80-процентный интерваи - <10-300 м), в период выкармливания птенцов - 213 м (медиана 225 м, 80-процентный интерваи 10-500 м) (Ruddock, Whitfield, 2007).

$\triangle$ истанция вспугивания Аербников с киаАок в Уральском регионе составляла обычно 2-8 м (Карякин, 1998). В соответствии с современными исследованиями показатели FID мия Аербников вне гнёзд в периOА насиживания яиц составики в среднем 

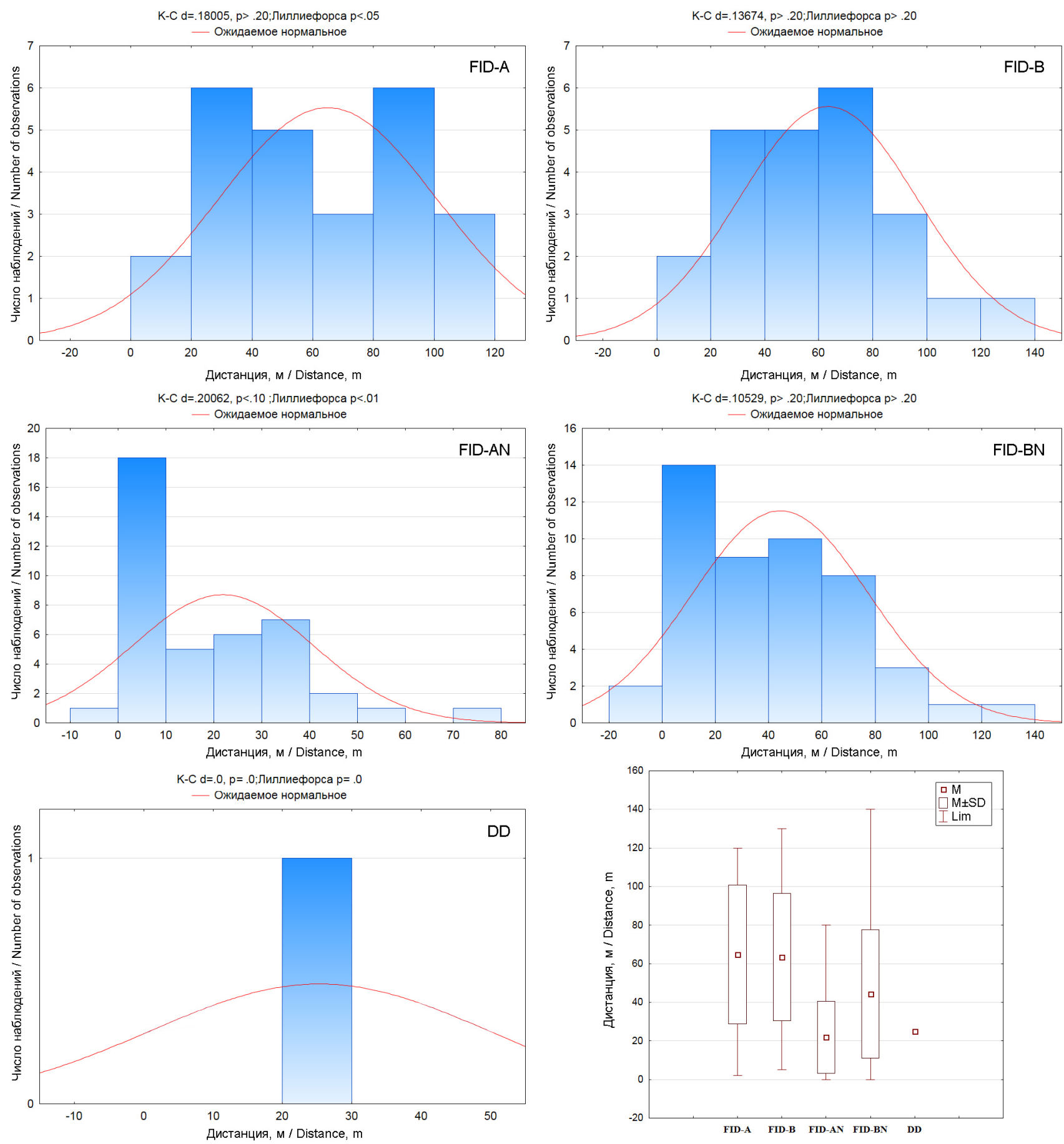

Pис. 22. Аистанции вспугивания (FID) Аербника (Falco columbarius): FID-A - Ао птицы на присаце в период насиживания яиц, FID-B $\Delta о$ птицы на присаце в период выкармливания птенцов, FID-AN - АО птицы на гнезде в период насиживания яиц, FID-BN - $\triangle$ птицы на гнезде в период выкармливания птенцов; DD - дистанции от гнёзд Аербника, АО края зоны нарушений, на которых гнёзда бросаются птицами.

Fig. 22. Flight initiation distances (FID) for the Merlin (Falco columbarius): FID-A - for a bird on a perch during incubation period, FID-B - for a bird on perch during the nestling-rearing period, FID-AN - for a bird in a nest during incubation period, FID-BN - for a bird in a nest during the nestling-rearing period; DD - distances from abandoned nests of the Merlin to the edge of the disturbances zones.

(n=25) 64,88 $\pm 36,07$ (2-120 м, медиана и мода - 50 м), в период выкармиивания птенцов - $(n=23)$ 63,48 $\pm 33,01$ (5-130 м, медиана - 60 м, мода - 80 м) (рис. 22). Аистанция вспугивания птиц с гнёзд в период киахки составила $(n=44) 21,93 \pm 18,79$ (0-80 м, медиана - 15 м, мода - 5 м), в период выкармиивания птенцов - $(n=49)$ 44,42 $\pm 33,23$ (0-140 м, медиана - 40 м, мода - 20 м). Не взлетели при проходе наблюдателей под гнездом 2,27 \% птиц на киалках из 44, а 27,27 \% взлетели с дистанции менее 10 м; с гнёзд с птенцами не взлетели 4,08 \% птиц из 49 при проходе 


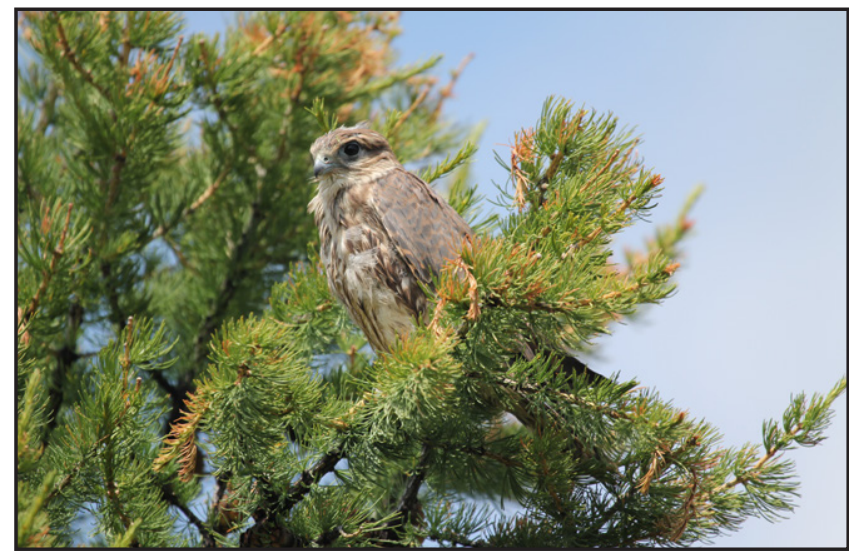

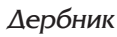

(Falco columbarius). Фото А. Левашкина.

Merlin

(Falco columbarius). Photo by A. Levashkin. Аа с Аистанции менее 10 м. под гнезАом, а 10,2 \% птиц покинули гнёз-

Мы не располагаем Аанными по влиянию на дербников нарушений на их участках, так как практически все найденные гнёзда были удаиены от рубок, строяшихся объектов и Ааже мест отдыха Аюдей даиее 500 м и мишь единственное гнездо с киалкой, устроенное в постройке вороны на берёзе, было брошено птицами во время выборочной рубки, прошедшей в 25 м от него.

Различными авторами в Великобритании были премложены бусерные зоны вокруг гнёзд Аербника радиусом 200-400 м (Currie, Elliott, 1997) и 200-300 м (Petty, 1998). В США мя Аербника (F. c. richardsonii), населяюшего прерии, была премложена буферная зона радиусом 366 м от активных гнёзд, внутри которой в сезон размноже-

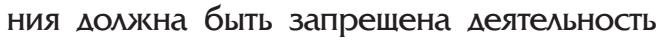
человека, такая как добыча полезных ископаемых, рубки, рекреация, устройство летних лагерей и баз отдыха или Аругие нарушения (Becker, Ball, 1983). Позже размер бусера был скорректирован $А$ 400 м и в качестве меры охраны было премложено сохранение опушек боров среди пастбиш (Becker, 1984; Konrad, 2004).

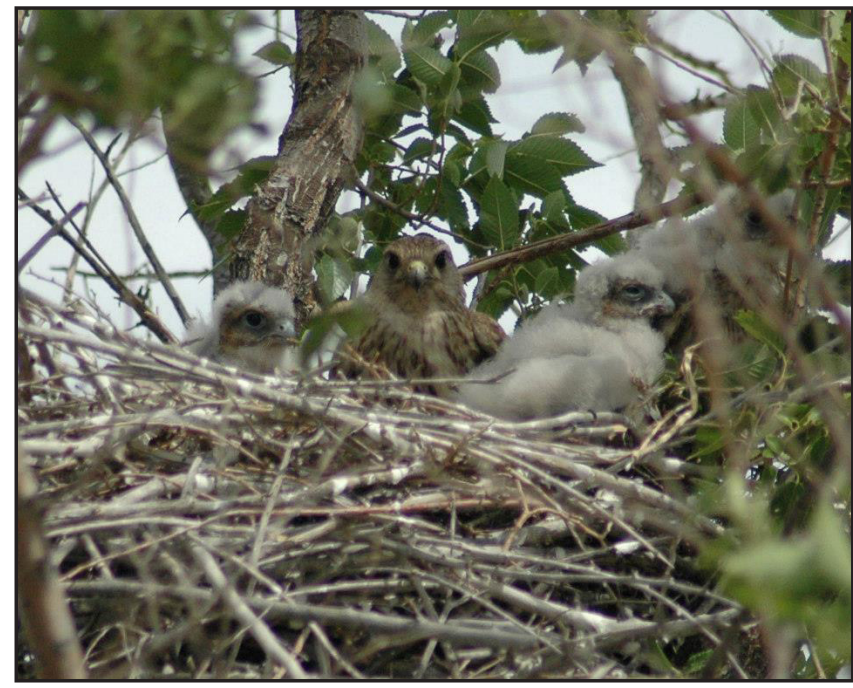

Видимо по аналогии с чеглоком и перепелятником из того же размерного киасса и близким по своим реакциям на беспокойство, обоснованный рахиус буферной зоны вокруг гнёзА Аербников Аолжен быть не менее 55 м, в оптимаиьном варианте 110 м. Аия стандартизации размеров буферных зон мия видов, имеюших гнёзда размером $\Delta о$ 0,4 м, необходимо придерживаться радиуса 150 м, с определёнными послаблениями в режиме (выборочные рубки и рубки ухода) вне гнездового периода в зоне от 110 оо 150 м, если иное не предусмотрено требованиями регионаиьного природоохранного законодательства.

\section{Пустельга обыкновенная (Falco tinnunculus)}

Обычный, местами многочисленный вид степной и лесостепной зоны Евразии, а также агроценозов лесной зоны, активно осваиваюший мяя гнездования городские и селькие поселения, многочисленный гнездяшийся вид на сооружениях человека (АЭП, зАания и пр.) (Kostrzewa, 1988; Village, 1990; Kostrzewa, Kostrzewa, 1993; Kubler et al., 2005; Piechocki, 2008), но в лесных популяциях вила в ряде регионов, в частности в Европейской части России и в Запанной Сибири, в последние десятилетия наблюдаются негативные тенденции. Процесс сокрашения численности пустельги не обошёл и боры Алтайского края, гле только за последние 15 лет от-

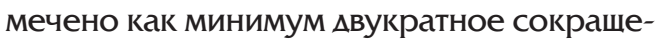
ние численности пустельги при стабильной ситуации или Ааже некотором росте численности в предгорьях Алтая.

FID для пустельг, встреченных в сельской местности вне гнёзд, в Испании составими в среднем $(n=5) 115,49 \pm 29,26$ м, в $\Delta$ aнии - $(n=6) 28,35 \pm 17,19$ м, в Чехии - $(n=3)$ 50,58 $\pm 13,71$ м (Diaz et al., 2013), во Франции - (n=9) 30,94 м (Møller, Erritzøe, 2010). В г. Орсе (Франция, пригород Парижа), в зоне городской застройки средние показатели FID мия пустельги наряду с Аругими городскими хишниками составики $(M \pm S E$, $n=30)$ 54,08+1,47 м (Møller, 2012). В Праге Аля негнездяшейся птицы - FID составила 36,35 м (Mikula, 2014). Аяя негнездяшихся пустельг в Аании FID при беспокойстве пе-

Самка дербника с птенцами в гнезде. Фото И. Карякина.

Female of the Merlin with nestlings in the nest. Photo by I. Karyakin. 
Птенцы пустельги в гнезде, устроенном на сосне в постройке чёрной вороны (Corvus corone). Фото И. Карякина.

Nestlings of the Kestre in the nest constructed by Oriental Crow

(Corvus corone) on the pine tree.

Photo by I. Karyakin. шеходом определены в 17-115 м, в среАнем 72 м ( $n=14)$ (Bijlsma, 2008).

По нашим данным показатели FID мяя пустельг вне гнёзА в период насиживания яиц составили в среднем $(n=60) 34,82 \pm 21,42$ (1-80 м, медиана и мода - 40 м), в период выкармиивания птенцов - $(\mathrm{n}=63)$ 29,62 20,07 (1-80 м, медиана - 30 м, мода - 50 м) (рис. 23). Аистанция вспугивания птиц с гнёзА в период киахки составила $(n=111)$ 16,27 17,82 (0-80 м, медиана и мода - 10 м), в период выкармиивания птенцов - $(n=135)$ 29,84 18,30 (0-90 м, медиана - 30 м, мода - 40 м). Не взлетеми при проходе наблюдателей под гнездом $10,81 \%$ птиц на киамках из 111, а 31,53 \% взлетели с Аистанции менее 10 м; с гнёзА с птенцами не взлетели 1,48 \% птиц из 135 при проходе под гнезАом, а 15,56 \% птиц покинули гнёзАа с Аистанции менее 10 м.

Аия близкого вида - седобородой пустельги (Falco cenchroides) из Австраиии FID составила в среднем $(n=14) 43,4 \pm 44,1$ м (Weston et al., 2012), мия мисьей пустельги (Falco alopex) из Асрики FID, полученные в Маии, составили 33 и 44 м, но ADs были много больше (61 и 81 м), FID мля птицы в Буркина-Фасо к востоку от Национаиьного парка Арли составила 51 м, AD - 67 м (Bijlsma, van Manen, 2017), мя негнездяшихся воробьиных пустельг (Falco sparverius) из США FID при Авижении на автомобиле составила в среднем $(M \pm S E)$ 40 11 м $(n=33$, диапазон 12-115 м), при Авижении пешком - 44+5 м ( $n=28$, диапазон - 10-100 м), доля вспугиваемых птиц составила $27 \%$ и $100 \%$ соответственно (Holmes et al., 1993).

Исследования посленних лет по влиянию беспокойства со стороны человека на концентрацию кортикостерона у воробьиных пустельг, мяя изучения механизмов репродуктивного стресса, по причине которого птицы оставляли

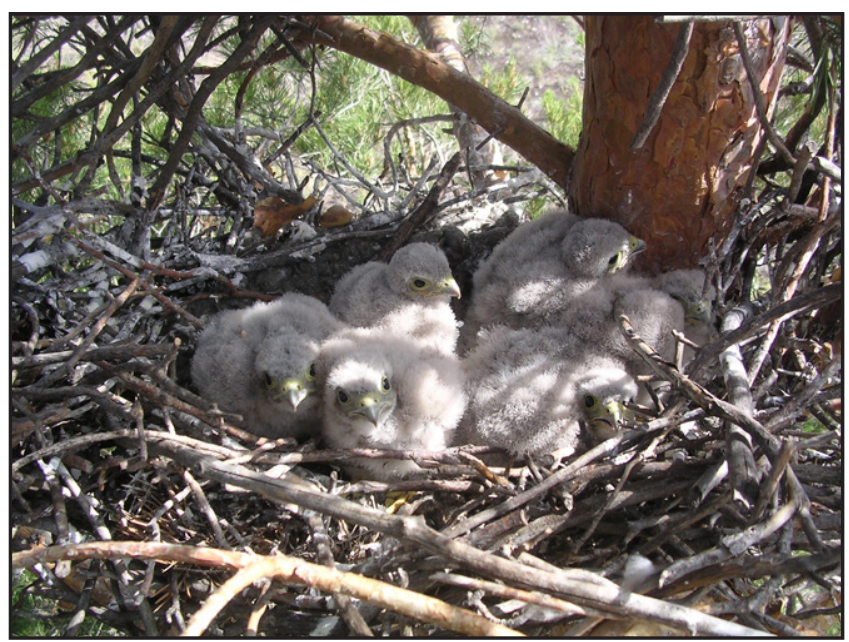

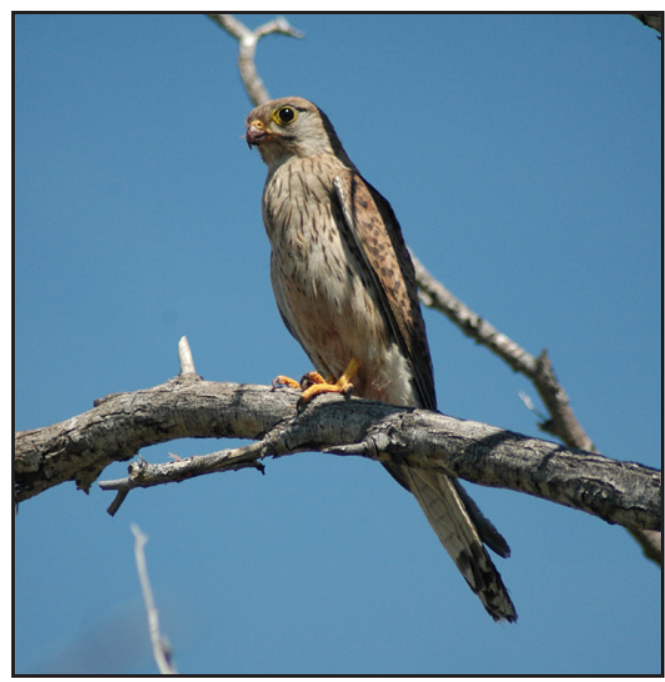

Пустельга (Falco tinnunculus). Фото И. Карякина. Kestrel (Falco tinnunculus). Photo by I. Karyakin.

гнёзда, показали, что гнездование вида в измененном человеком ландшасте не облзательно указывает на его толерантность к антропогенным факторам, вызываюшим стресс. В частности, в данном исследовании 26 (36 \%) из 73 попыток гнезАования пустельги не удались и $88 \%$ неудач произошло во время инкубации, причём пустельги, гнездяшиеся в районах с наиболее высоким уровнем беспокойства, в 9,9 раз чаше бросали клахки, чем птицы, гнёзда которых располагались в зоне с меньшим уровнем беспокойства и различных нарушений среды обитания (Strasser, 2010; Strasser, Heath, 2013).

Согласно нашим исследованиям, ближайшая Аистанция от гнезАа пустельги $\Delta$ края зоны нарушений, на которой гнездо осталось жилым, составляет 50 м, при средней дистанции DD, на которой гнёзда оказались брошенными - $(n=3)$ 22,0 $\pm 19,97$ м, от $5 \Delta$ о 44 м (рис. 23). Собственно малее 50 м от границ рубок и строяшихся объектов все гнёзда пустельг оставались жилыми.

В Великобритании предложены буферные зоны вокруг гнёзд пустельги рахиусом 100-200 м (Petty, 1998), в США - От 50 АО 400 м (Richardson, Miller, 1997).

Видимо, по аналогии с Аругими мелкими соколами, близкими по своим реакциям на беспокойство, обоснованный радиус бусрерной зоны вокруг гнёзА пустельг АОАжен быть не менее 55 м, в оптимальном варианте - 110 м. Ая стандартизации размеров буферных зон дмя видов, имеюших гнёзда размером Ао 0,4 м, необходимо 

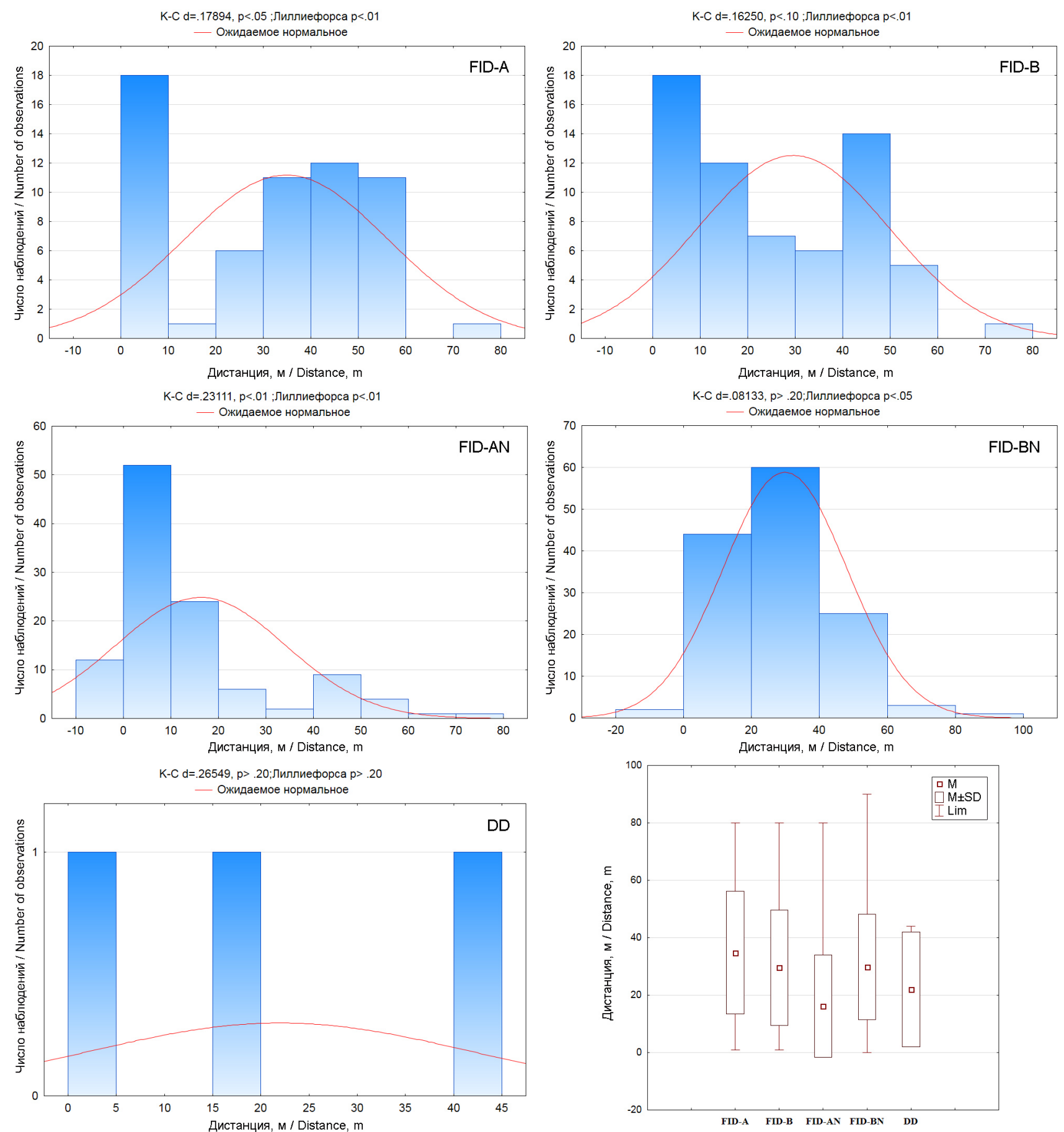

Рис. 23. Аистанции вспугивания (FID) пустельги (Falco tinnunculus): FID-A - $\Delta$ птицы на присаце в период насиживания яиц, FID-B - $\triangle$ о птицы на присаце в период выкармливания птенцов, FID-AN - $\Delta$ птицы на гнезде в период насиживания яиц, FID-BN - $о$ птицы на гнезде в период выкармливания птенцов; DD - дистанции от гнёзд пустельги, Ао края зоны нарушений, на которых гнёзда бросаются птицами.

Fig. 23. Flight initiation distances (FID) for the Kestrel (Falco tinnunculus): FID-A - for a bird on a perch during incubation period, FID-B - for a bird on perch during the nestling-rearing period, FID-AN - for a bird in a nest during incubation period, FID-BN - for a bird in a nest during the nestling-rearing period; $D D$ - distances from abandoned nests of the Kestrel to the edge of the disturbances zones.

придерживаться радиуса 150 м, с определёнными послаблениями в режиме (выборочные рубки и рубки ухода) вне гнезАового периода в зоне от 110 Ао 150 м, если иное не предусмотрено требованиями регионаиьного природоохранного законодательства.

\section{Филин (Вubo bubo)}

Несмотря на то, что в Красном хисте МСОП филин числится как вид, не требуюший особого внимания (категория Least Concern), он внесён в I Приложение директивы ЕС о птицах и охраняется на государственном уровне в большинстве 
стран ареала (König, Weick, 2008). В Европе (примерно $20 \%$ от плошади гнезАового ареала вида) численность популяции филина оценивается в 18,5-30,3 тыс. пар, что соответствует 36,9-60,6 тыс. взросмых птиц (BirdLife International, 2017d). Масштабные программы реинтродукции и строгая охрана вила, особенно в Германии, Франции, Бельгии, Швейцарии и Скандинавии, позволили Аобиться восстановления популяций филина с 1970-х годов, после их крушения, отмечавшегося ранее. Тем не менее, филин до сих пор страдает от человеческого преследования, отравления, гибели на Аорогах, АЭП, ограждений из колючей проволоки, и эта смертность является значительной. Филин чрезвычайно чувствителен к вторжению ^юдей на гнездовые участки, и малейшее беспокойство привоАит к тому, что птицы нацолго покидают гнёзда, и часто это становится причиной гибели киаАок и выводков. Горные мыжи, альпинизм и скалолазание, а также другие виды досуга приводят К тому, что ^юАи неосознанно находятся вблизи гнёзд фрилина, что приводит к их гибели (Tucker, Heath, 1994; Holt et al., 2017). Рекомендации по охране гнездовых участков филина, а также мест потенциального гнездования вида, предписывают их искиючение из лесозаготовок (Holt et al., 2017; BirdLife International, 2017d).

Исследования, проведённые в лесном национальном парке Аахиа-Аеским-Сусрми в Греции показаяи, что филин населяет чаше всего лесные места обитания, а результаты моделирования показаяи, что скалистые районы на более низких высотах с высоким процентом лесного покрова являются наиболее подходяшим местом обитания этого виАа, причём присутствие филина в этих местообитаниях уменьша-

Eagle Owl (Bubo bubo). Photo by I. Karyakin.

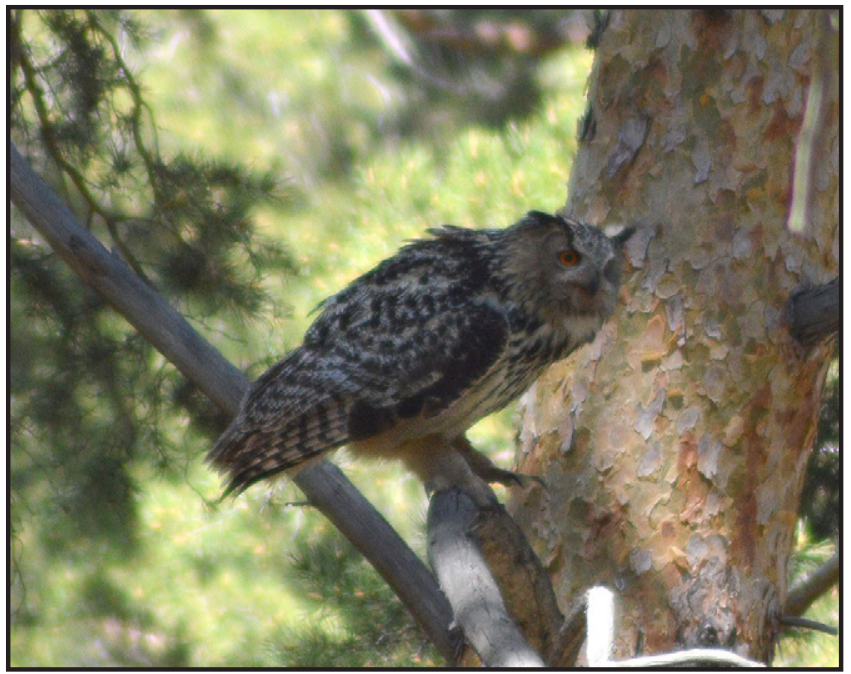

ется по мере приближения к человеческому жилью (Kret et al., 2014). В Итаиьянских Альпах в 1994-2000 гг. Аистанции от гнёзА филина $\Delta$ б ближайших меревень состав-

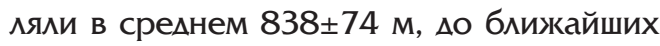
нарушенных человеком местообитаний 313 \pm 55 м; фрилины тяготели на гнездовании ближе к городам и интенсивно культивируемым урбанизированным Аолинам, из-за наличия более доступной пиши, но за это "платили" повышенной смертностью на ^ЭП и автотрассах (Marchesi et al., 2002). $\triangle$ есятилетием ранее высокие уровни гибеми на АЭП и автотрассах были характерны также мяя Швейцарских Аиьп ( $n=29,55,2$ \% и 44,8\% соответственно; Haller, 1978). В Германии наряду с вышеперечисленными факторами значимое место занимало преследование человеком (отстрел, раззорение гнёзд, отлов, отравление): (1)

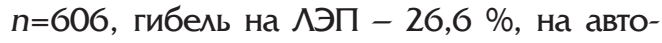
трассах - 26,9 \% и преследование - 2,8 \% (Wicki, 1979); (2) n=211, 23,7 \%, 10,9\% и 25,1 \% (Radler, Bergerhausen, 1988), как, собственно, в Финляндии $(n=75$, гибель на ^ЭП - 16,0 \%, на автотрассах - 13,3\% и преследование - 17,3 \%; Saurola, 1979) и Швеции $(n=101,19,8$ \%, 12,9 \% и 5,0 \%, соответственно; Olsson, 1979). В Испании основными причинами смертности филинов $(n=115)$ являются гибель на АЭП $(46,9 \%)$, голод $(20,8 \%)$ и столкновение с транспортом на автотрассах (7,9 \%) (LeonOrtega et al., 2017). Таким образом, симин, будучи антропособом, в Европейской части гнездового ареала, вынужден тяготеть к умеренно освоенным человеком ландшастам, изобилуюшим Аобычей, но несушим определённые угрозы его выживанию. При этом речь илёт преимушественно о наскаиьногнездящихся птицах. В России, гАе на большей части территории лесной зоны филин гнездится на земле, и в осваиваемых человеком регионах также тяготеет к местам концентрации добычи, пресс на него со стороны человека ешё более ошутим. В частности мия А^тайского края наглянно показано сокрашение численности филина, гнездяшегося на земме в Алтайских борах по причине рубок леса и сопутствуюшего беспокойства при стабильной ситуации с ним в полосе предгорий, гАе фрилин гнездится на скалах (Важов, Рыбальченко, 2013; Карякин, 2014).

Нам совершенно не удалось обнаружить публикаций по Аистанциям вспугивания филинов, несмотря на Аостаточно большое количество исследований этого вида в Европе. 

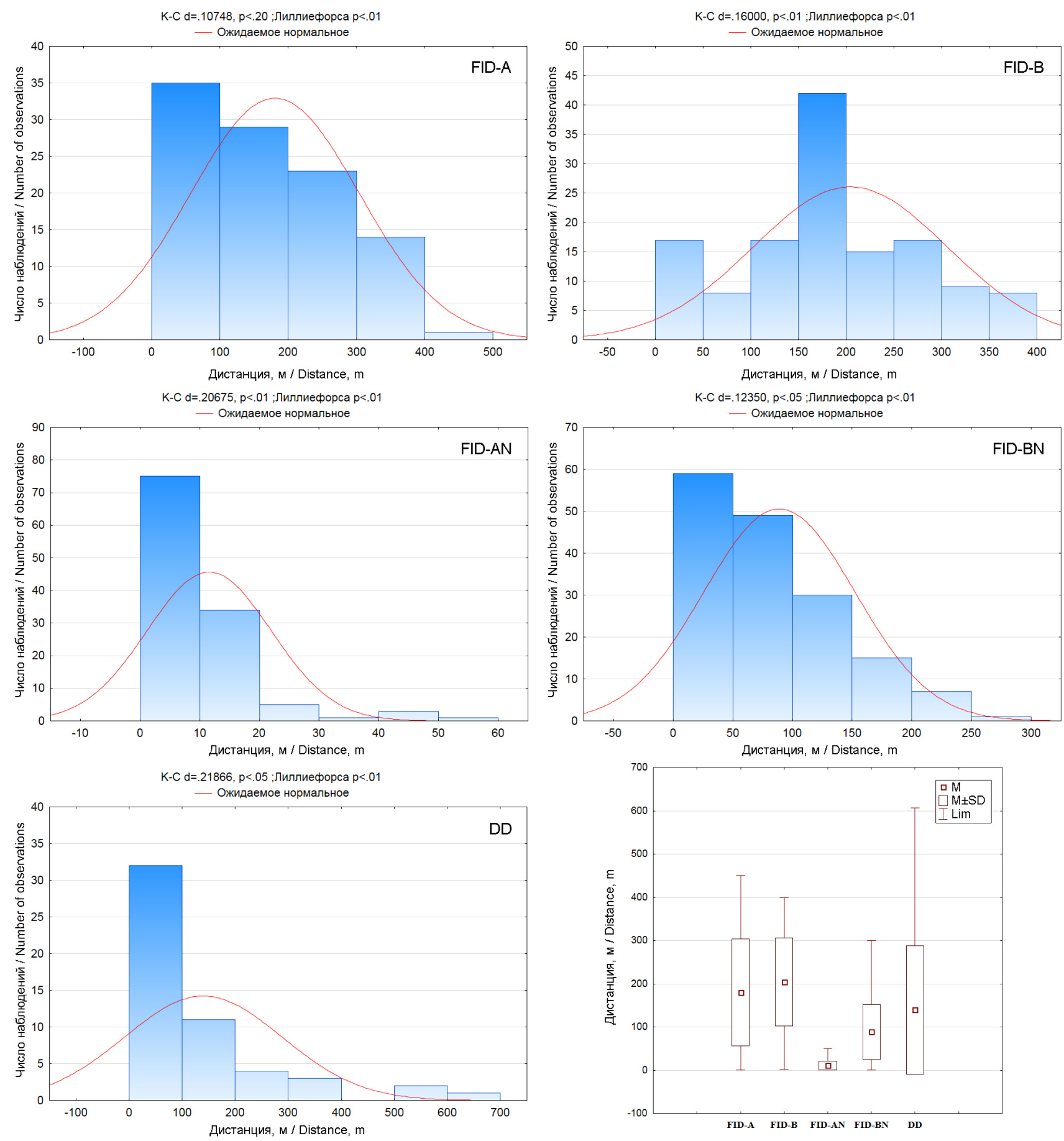

Pис. 24. Аистанции вспугивания (FID) филина (Bubo bubo): FID-A - $\Delta$ птицы на присаде в период насиживания яиц, FID-B - $\Delta O$ птицы на присаце в период выкармиивания птенцов, FID-AN - $\Delta$ птицы на гнезде в период насиживания яиц, FID-BN - $\Delta$ о птицы на гнезде в период выкармиивания птенцов; DD - дистанции от гнёзд филина, до края зоны нарушений, на которых гнёзда бросаются птицами.

Fig. 24. Flight initiation distances (FID) for the Eagle Owl (Bubo bubo): FID-A - for a bird on a perch during incubation period, FID-B - for a bird on perch during the nestling-rearing period, FID-AN - for a bird in a nest during incubation period, FID-BN - for a bird in a nest during the nestling-rearing period; $D D$ - distances from abandoned nests of the Eagle Owl to the edge of the disturbances zones.

По нашим Аанным показатели FID ммя филина вне гнёзА в период насиживания яиц составили в среднем $(n=102)$ $180,6 \pm 123,61$ (1-450 м, медиана -180 м, мода - 300 м), в период выкармливания птенцов - ( $n=133)$ 204,26 $\pm 101,83$ (2-400 м, медиана и мода - 200 м) (рис. 24). Аистанция вспугивания птиц с гнёзА в пери- од киалки составила ( $n=119) 11,57 \pm 10,40$ (1-60 м, медиана - 10 м, мода - 5 м), в период выкармиивания птенцов - $(n=161)$ 89,06 $\pm 63,53$ (1-300 м, медиана - 80 м, мода - 100 м). Взлетели при подходе наблюдателей к гнезду с Аистанции менее 10 м 48,74 \% из 119 птиц в период насиживания киадок и 6,21\% птиц из 161 в период 
выкармиивания птенцов (все случаи при возрасте птенцов младше 2-х недель). По мере взросления птенцов дистанция вспугивания фрилина увеличивается и если при киакее и пуховиках $А$ 7 Аней филин на гнезде предпочитает лежать $\Delta о$ последнего, то при птенцах старше 2-х недель, старается слетать Ааже $\Delta$ о того, как подходяший к гнезду наблюдатель сможет увидеть его слёт. В случае регистрации Аистанций вспугивания птиц вне гнёзд, часто их Ааже не удаётся идентифицировать $А$ вида во время взлёта - илентисрикация происхоАит мишь по пуху и/ими погадкам при подходе на точку вспугивания птицы.

Средняя дистанция от гнезда фииина $\Delta$ края зоны нарушений, на которой гнезАо осталось жилым, составляет $(n=9) \quad 340,0 \pm 183,22$ м (90-600 м), при средней Аистанции DD, на которой гнёзда оказались брошенными - $(n=53)$ $139,92 \pm 148,63$ м, от 1 до 607 м (рис. 24). Видимо мля наземногнездяшихся филинов в равнинных лесах следует считать опасной зону до края нарушения в 610 м, так как мы не выявили оставления силинами гнёзд после рубок, проведённых на расстоянии от гнёзд больше этой Аистанции. В то же время на расстояниях от гнёзА $\Delta$ о нарушений от 270 Ао 600 м фимин может успешно размножаться в случаях, если имеется естественный рубеж, отделяюший охраняемый гнездовой участок фрилина от зоны нарушений, например русло реки, пастбише или открытое болото с нетронутой опушкой леса. При рубках опушки леса на противоположной от гнезда стороне болота в ралиусе $\Delta о$ 600 м от гнезда, филины оставляли гнёзда на следуюший сезон, смешаясь далее 600 м от рубок.

В Венгрии мия фрилина премиагается бурерная зона рахиусом 50-200 м (0,8-12,56 га) с запретом изменения местообитаний в радиусе 50 м и с запретом беспокойства в период с 1 февраля по 31 июля, но речь идёт о наскамьногнездяшихся птицах (Pongracz, Horvath, 2010). Аля Уральско-

Птенцы филина в гнезде под сосной. Фото И. Карякина.

Nestlings of the Eagle Owl in the nest under a pine tree. Photo by I. Karyakin. го региона России предмаганись бусерные зоны вокруг гнёзд рахиусом от 500 м Ао 1 км (Карякин, 1998).

В Красной книге Алтайского края м^я охраны филина требуется выделение кАючевых биотопов с последуюшим созданием особо зашитных участков леса в радиусе не менее 300 м от гнёзд с запретом всех видов рубок лесных насаждений в ^юбое время года. Вылеление зон особой охраны в ленточно-боровых и приобскоборовых заказниках с вкАючением в них местообитаний вида. Запрет горных разработок, геологоразвеАки и иной хозяйственной и рекреационной Аеятельности в местах обитания вила, способной привести к транссормации местообитаний и/или беспокойству птиц (Важов, Бахтин, 2016d). В Красной книге Нижегородской области закреплена необходимость обеспечения соблюдения запрета всех видов рубок леса (в том числе санитарных) в местах обитания филина и вылеления вокруг гнёзд охранных зон не менее 250 м (Бакка, 2014е).

Согласно нашим исследованиям, обоснованный радиус буферной зоны вокруг гнезда филина должен быть не менее 349 м (табл. 5), в оптимальном варианте - 698 м, а м^я гарантированного сохранения участка - 800 м. Сложность с реализацией вылеления бусерных зон вокруг гнёзд филина без орнитологического обследования состоит в том, что в равнинных лесах России этот вил гнездится на земле и после того, как птенцы, ешё не умея летать, покидают гнездо, идентисрицировать его на местности неподготовленному человеку крайне сложно. Это является реальной проблемой охраны филина даже на тех территориях, гАе ответственные лесопользовате-

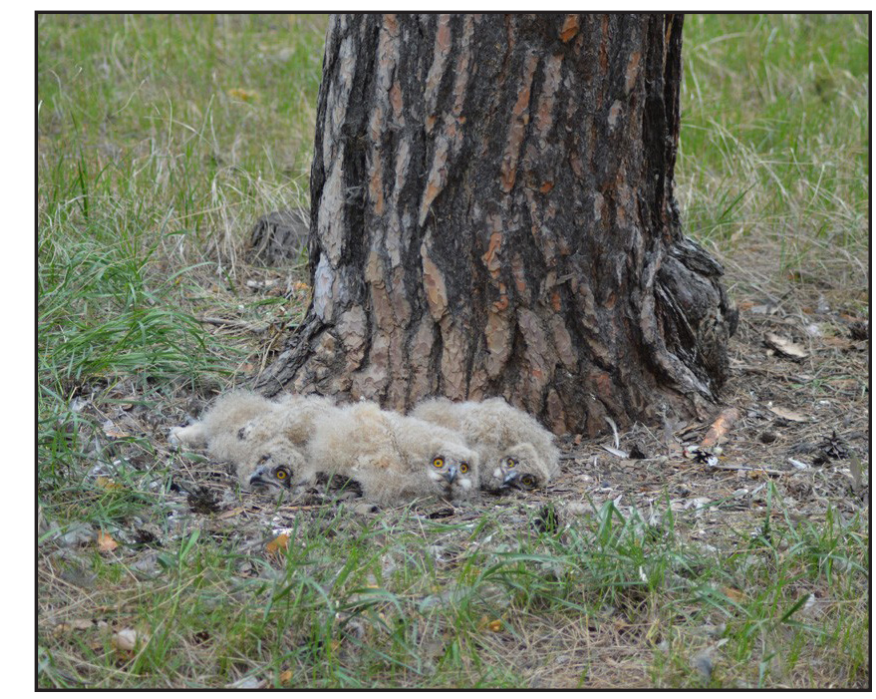




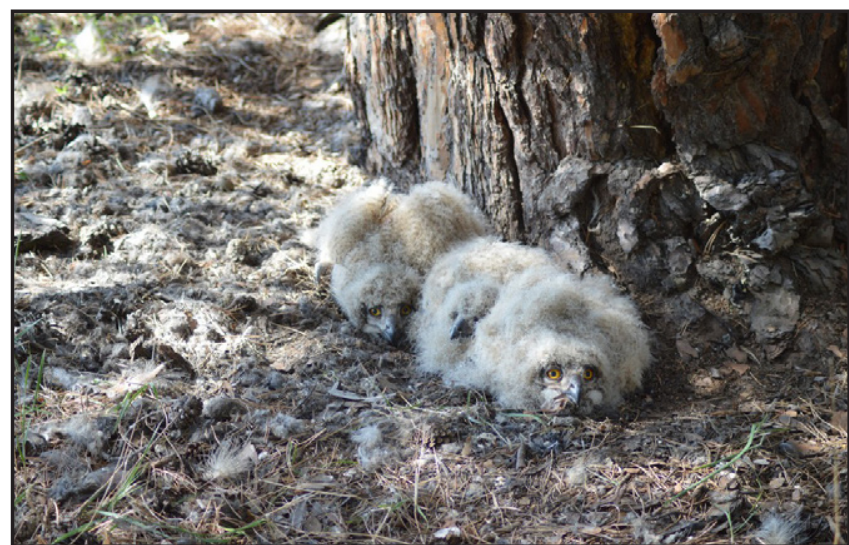

Птенцы филина в гнезАе поА сосной (Аитайский край) Фото И. Карякина.

Nestlings of the Eagle Owl in the nest under a pine tree (Altai Kray). Photo by I. Karyakin. гнездования реАких видов. ки готовы выводить из лесосеки участки

\section{Бородатая неясыть (Strix nebulosa)}

Эта сова циркумполярно населяет бореальную зону Северного полушария - она обычна в таёжных лесах, а на юге лесной зоны и в лесостепи немногочисленна (Пукинский, 2005b; König, Weick, 2008), в светлохвойных лесах севера Запанной Сибири и в Восточной Сибири по числен-

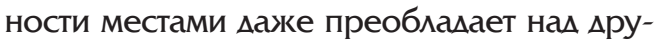
гими виАами сов.

Бородатая неясыть устраивает гнёзда обычно в постройках Аругих хишных птиц, преимушественно тетеревятника и канюка, реже в выгнивших полостях на вершинах обломышей деревьев различных видов, в основном миственницы, сосны, берёзы и осины, причём такой стереотип гнездования более характерен мия Северной Америки и кишь с кона XX века стаи регистрироваться в Северной Европе (Карякин, 1998; Пукинский, 2005b; Wu et al., 2016).

В Северной Америке лесопользование за последние 100 лет имело как положительное, так и отрицательное влияние на качество среды обитания бородатой неясыти (Huff et al., 1996), но большинство авторов скионяется к тому, что негативное влияние было более ошутимым, чем позитивное (Williams, 2012). Исследованиями в Орегоне показано, что большинство (72 \%) гнёзд бородатой неясыти находились в нетронутых рубками вылелах леса, 19 \% - в вылелах, частично затронутых рубками, и 9 \% гнёзд были расположены в пределах 200 метров от рубок (Bull, Henjum, 1990). На основании обследования 60-80 \% лес-

Бородатая неясыть (Strix nebulosa). Фото И. Карякина.

Great Grey Owl (Strix nebulosa). Photo by I. Karyakin. ных вылелов на каждой изучаемой территории, авторы слелали зак^ючение, что совы предпочитали не рубленные участки леса, потому что большинство мёртвых $\Delta е-$ ревьев подходяшего диаметра, пригодных мя гнездования неясытей, и гнезАовых построек тетеревятника, используемых совами, располагалось именно в участках леса незатронутых рубками. Предполагалось, что практика рубок в 70-80-х гг. XX столетия в Северной Америке может затронуть Ао $75 \%$ гнездяшихся неясытей (Duncan, 1993). Рубки уменьшили количество гнезАопригодных деревьев, сильно разредили гнезАопригодный лес, потерявший зашитные свойства мия бородатой неясыти, а также сушественно сократили число мёртвых деревьев и коряг, используемых как взрослыми птицами, так и слётками в качестве присах (Bryan, Forsman, 1987; Quigley et al., 1996; Wisdom et al., 2000).

В Северной Европе отмечено, что сплошные рубки (не более 400 м шириной) могут временно увеличить площамь охотничьих биотопов мия бородатой неясыти в условиях сплошного леса, и, возможно, увеличить численность мелких млекопитаюших (Sulkava, Huhtala, 1997), но по наблюдениям в США, сорормированные посредством таких рубок охотничьи биотопы, без Аолжного подлержания их структуры неАолговечны по сравнению с продолжительностью жизни естественных лугов, и теряют свою ценность мя сов через 10-30 лет, что ведёт к сокрашению численности неясытей, освоивших вырубки (Habeck, 1994).

Опубликованных исследований, направленных на изучение ответа бородатых неясытей на беспокойство человеком, нам найти не удалось. Что очень странно, так как этот вид проявляет повышенную терпимость к людям на своих гнездовых тер-

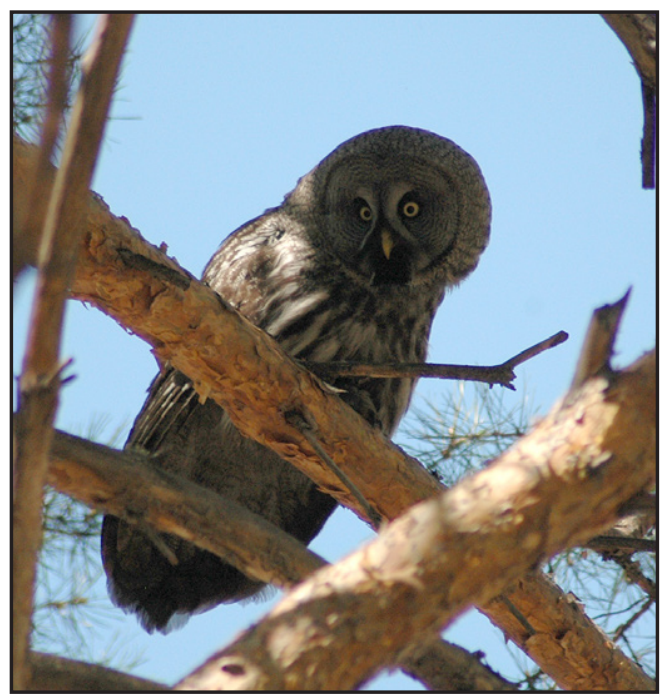



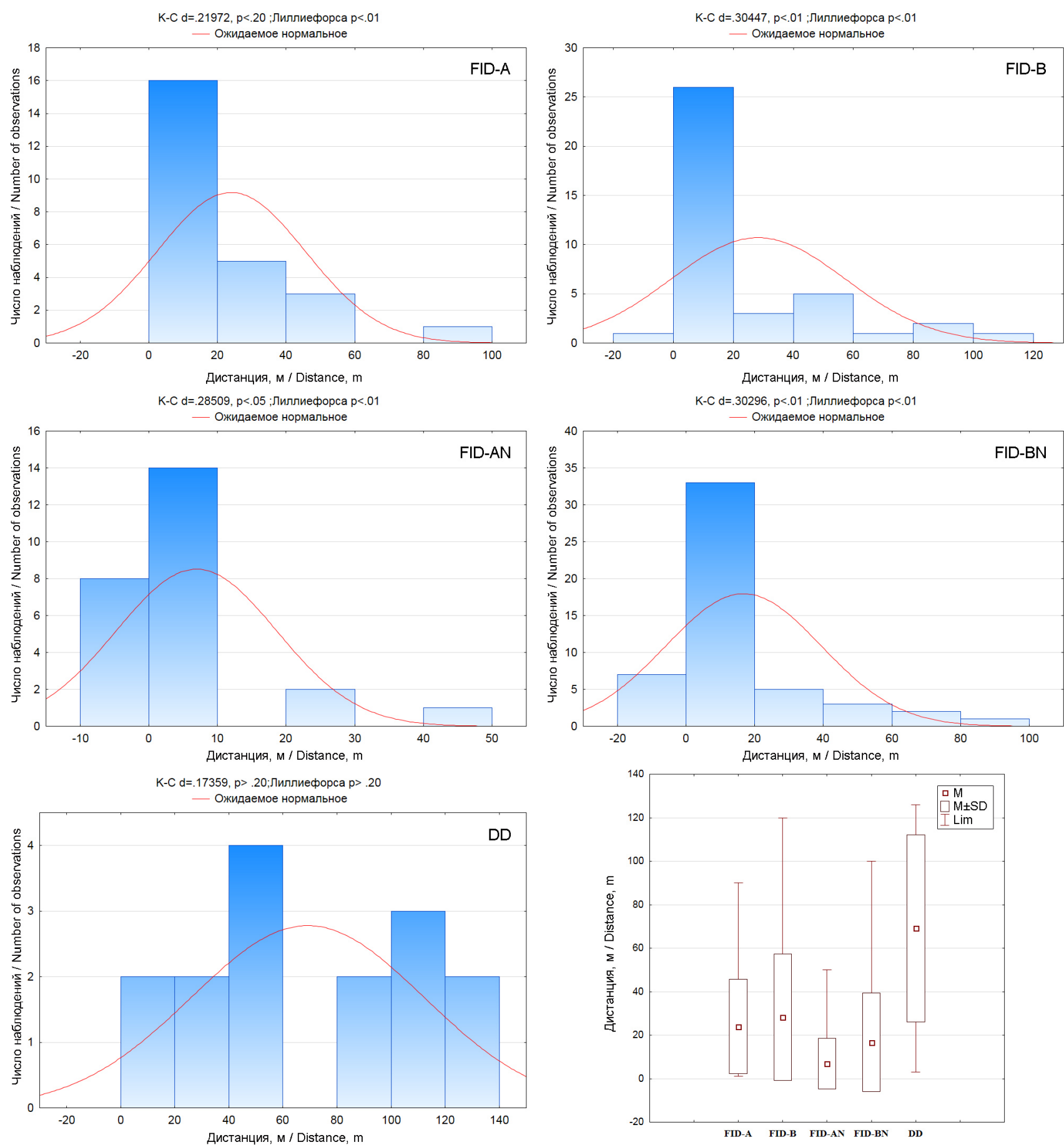

Рис. 25. Аистанции вспугивания (FID) бородатой неясыти (Strix nebulosa): FID-A - $А$ птицы на присаце в период насиживания яиц, FID-B - Ао птицы на присаце в период выкармиивания птенцов, FID-AN - $о$ птицы на гнезде в период насиживания яиц, FID-BN - $\triangle O$ птицы на гнезце в период выкармливания птенцов; DD - Аистанции от гнёзд бородатой неясыти, Ао края зоны нарушений, на которых гнёзда бросаются птицами.

Fig. 25. Flight initiation distances (FID) for the Great Grey Owl (Strix nebulosa): FID-A - for a bird on a perch during incubation period, FID-B - for a bird on perch during the nestling-rearing period, FID-AN - for a bird in a nest during incubation period, FID-BN - for a bird in a nest during the nestling-rearing period; DD - distances from abandoned nests of the Great Grey Owl to the edge of the disturbances zones.

риториях, чем отличается от всех мругих представителей своего размерного киасса. Особенность бородатой неясыти практически не реагировать на человека, создаёт большие проблемы в использовании AD и FID при обосновании размеров охранных зон Аия этого виАа.
По нашим Аанным показатели FID мия бородатых неясытей вне гнёзд в период насиживания яиц составили в среднем $(n=25)$ 23,96 21,73 м (1-90 м, медиана - 20 м, мода - 10 м), в период выкармиивания птенцов - ( $n=39)$ 28,28 $\pm 29,06$ м (0-120 м, медиана и мода - 20 м) (рис. 25). Стоит об- 


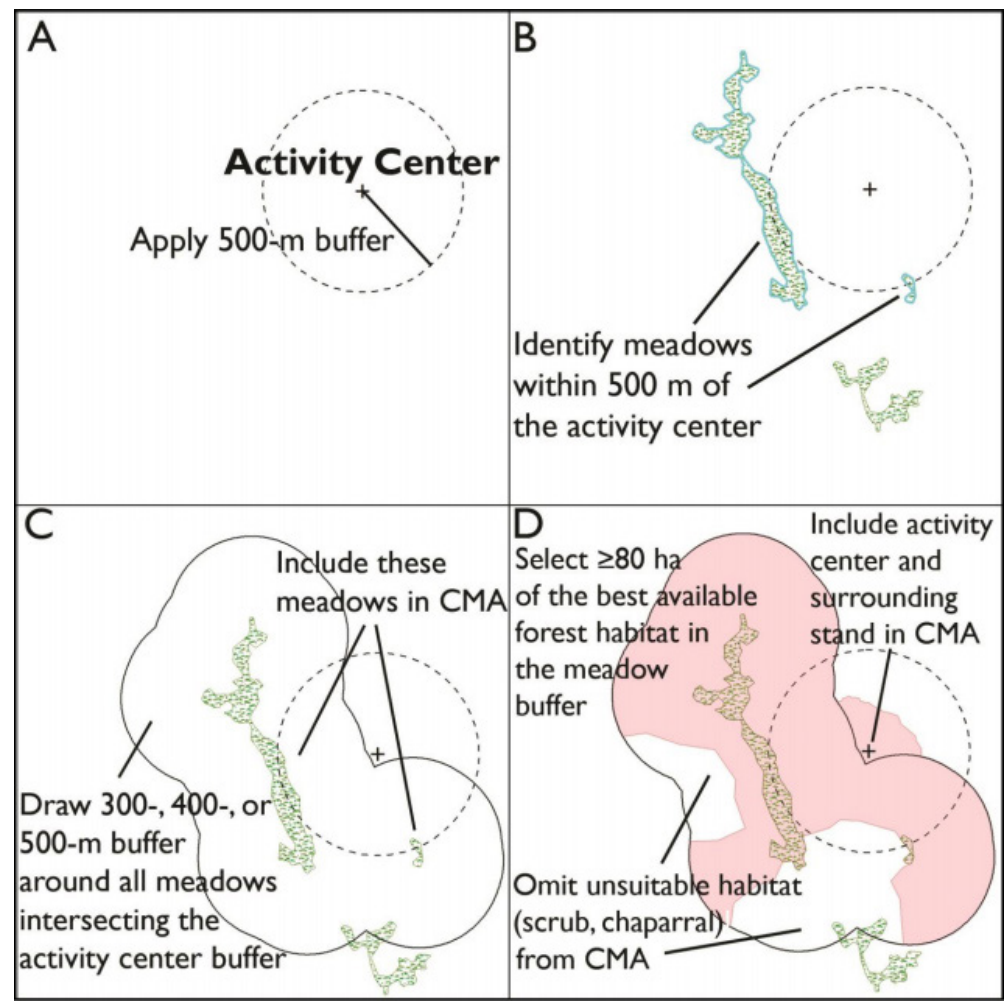

Пошаговая методика создания охраняемой зоны вокруг гнезда бородатой неясыти: окончательная охраняемая зона вкџючает в себя 161 га леса и 13 га лугов. По: Wu et al., 2016.

Step-by-step method for creating a protected zone around a nest of the Great Grey Owl; the resulting protected zone encompasses 161 ha of forest and 13 ha of meadow landscapes. From: Wu et al., 2016. ратить внимание на то, что 1 птица из 39 вообше не взлетела с присацы при проходе наблюдателя под ней, а 15,38 \% птиц взлетели с Аистанции менее 10 м. Аистанция вспугивания птиц с гнёзА в период киадки составила $(n=25)$ 6,92 $\pm 11,72$ м (0-50 м, медиана - 3 м, мода - 0 м), в период выкарммивания птенцов - $(n=51) \quad 16,73 \pm 22,66$ (0-100 м, медиана - 8 м, мода - 10 м). Не взлетели при проходе наблюдателей под гнездом 32,0 \% птиц на киадках из 25, а 44,0 \% взлетели с Аистанции менее 10 м; с гнёзд с птенцами не взлетели 13,73 \% птиц из 51 при проходе под гнезАом, а 39,22 \% птиц покинули гнёзда с Аистанции менее $10 \mathrm{~m}$.

При абсолютно неадекватной видимой толерантности к беспокойству, бородатая неясыть очень чутко реагирует на нарушения структуры леса на гнездовом участке. И если по Аистанциям вспугивания она похожа на какого-то мелкого хишника, типа пустельги, то по ответу на нарушения - на крупного хишника. Последнее связано не с беспокойством во время рубок, а с нарушением зашитных свойств леса на гнезАовом участке, которые целают гнёзда и киючевые присады неясытей доступными мяя хишников, оказываюших на неясытей пресс, в частности филина и, в меньшей степени, тетеревятника. Средняя дистанция от гнезда бородатой неясыти до края зоны нарушений, на которой гнездо остаАось жилым, составляет $(n=3)$ 98,67 $\pm 5,51$ м
(95-105 м), при средней дистанции DD, на которой гнёзда оказамись брошенными ( $n=15$ ) 69,13 $\pm 43,06$ м, от 3 Ао 126 м (рис. 25). $\triangle$ истанции $А$ края сплошной рубки, на которых гнёзда были брошены неясытями, варьировами от 3 мо 115 м, составив в среднем $(n=6) 59,67 \pm 51,01$ м, аналогичные Аистанции $А$ края выборочной рубки варьировами от $22 \Delta$ о 126 м, составив в среднем $(n=9)$ 75,44 $\pm 38,81$ м. Таким образом, зона от края нарушения $\Delta о$ гнезда, в которой неясыти со $100 \%$ вероятностью бросают гнёзда, составляет 95 м, опасная зона, в которой имеется определённая вероятность оставления гнёзд - 90-150 м. $\Delta$ алее 150 м от гнезда бородатая неясыть терпимо относится к нарушениям, связанным с рубкой леса.

Амя северо-запацной Миннесоты были установлены требования, чтобы все сушествуюшие и потенциальные гнёзда бородатой неясыти сохранялись, вокруг них вылелялась буферная зона радиусом не менее 100 м, а новые рубки на гнездовых территориях неясытей проводились рядом со старыми вырубками не менее, чем через 5 лет (Haws, 1987). Позже различными исследователями мия США и Канады на основании радиопрослеживания птиц были предможены бусерные зоны вокруг гнёзд бородатой неясыти не менее 300 м (Winter, 1986, Bouchart, 1991, Duncan, 1997). В настояшее время в Камисрорнии рекомендуется вылелять буферные зоны не только вокруг гнёзд, но и вокруг Аругих "центров активности" птиц (мест встречи слётков, взрослых птиц в сезон размножения), ввиду сложности обнару-

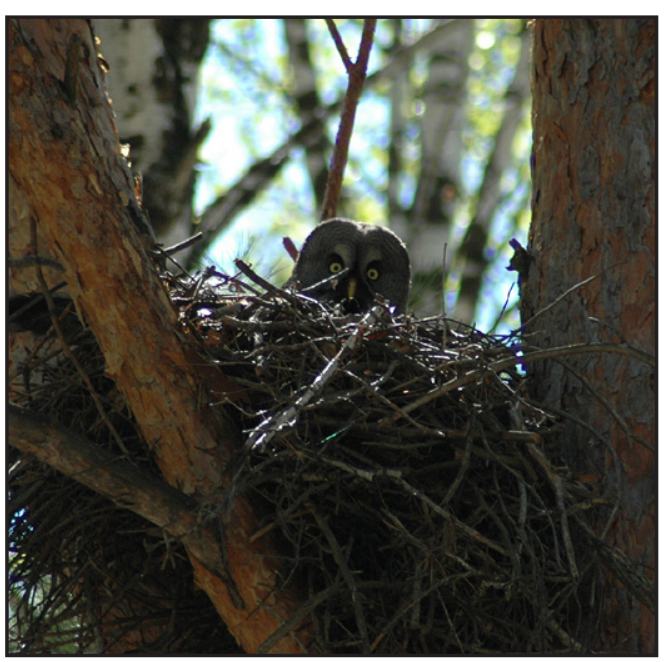

Бородатая неясыть в гнезце (Аитайский край) Фото И. Карякина.

Great Grey Owl in the nest (Altai Kray). Photo by I. Karyakin. 
жения гнёзд бородатой неясыти, устроенных на вершинах обломышей и в "мётлах". Охранные зоны не обязательно должны быть сконсигурированы как круг вокруг центра активности птиц, они могут быть Аюбой формы, которая включает в себя лесные территории и прилегаюшие к ним луга, если это возможно. Охранные зоны Аолжны содержать не менее 80 га леса и лугов в рахиусе 500 м (1640 фуутов) от гнезАа или центра активности птиц, причём вокруг кажАого куга, пересекаемого 500-метровым бусером, Аолжен быть также отложен бусер, рахиусом 300, 400 или 500 метров в зависимости от высоты местности наА уровнем моря (Wu et al., 2016). Принятые лесной службой США руководяшие принципы управления требуют вылеления вокруг всех известных гнёзд бородатой неясыти не менее 20 гектаров (50 акров) лесных территорий и лугов и в радиусе 400 м от активных гнёзА запрешают изменение растительности и Аорожное строительство с 1 марта по 15 августа, хотя санитарная рубка отдельных деревьев может быть разрешена, если она не мешает гнездованию (US Forest Service, 2004).

В Красной книге Украины закреплено требование создания микрозаказников радиусом 0,5 км вокруг гнёзА бородатой неясыти (Аомашевский, Бумар, 2009).

В Красной книге Нижегородской области закреплена необходимость обеспечения соблюдения запрета всех видов рубок леса в местах обитания бородатой неясыти и выделения вокруг гнёзд охранных зон не менее 250 м (Бакка и мр., 2014). В Красной книге Алтайского края мия охраны бородатой неясыти требуется выделение киючевых биотопов с последуюшим созданием особо зашитных участков леса (радиусом не менее 200 м от гнёза) с запретом всех видов рубок лесных насаждений в любое время года и Аругой хозяйственной и рекреационной деятельности, способной привести к трансрормации местообитаний и/или беспокойству птиц. Вылеление зон особой охраны в ленточно-боровых и приобско-боровых заказниках с вкАючением в них местообитаний вида. (Важов, Бахтин, 2016е).

Согласно нашим исследованиям, обоснованный рахиус бусерной зоны вокруг гнезда бородатой неясыти Аолжен быть не менее 111 м (табл. 5), в оптимальном варианте - 222 м. Так как бородатая неясыть во время размножения занимает в основном гнёзда тетеревятника и канюка, размером от 0,4 Ао 1 м, то мия стандартизации размеров буферных зон мия этой совы, необходимо придерживаться радиуса 300 м, с определёнными послаблениями в режиме (выборочные рубки и рубки ухоАа) вне гнездового периода в зоне от 222 Ао 300 м, если иное не требуется в регионаиьных Красных книгах (см., например, Бакка и нр., 2014).

\section{Мииннохвостая неясыть (Strix uralensis)}

Обычный виА лесной зоны Евразии от низовьев Вислы и Скандинавии до Тихого океана, нарашиваюший численность в лесах Северо-Запала России с 1940-1970 гг. XX столетия (Пукинский, 2005a; König, Weick, 2008), в последние годы расширяюший ареал в ряле южных регионов Европы и активно расселяюшийся по лесостепи (Паженков и Ар., 2009; Bashta, 2009), а также начинаюший осваивать города (Dravecky, Obuch, 2012).

Аиннохвостая неясыть преимушественно Ауплогнёздник, однако из-за очевидного недостатка деревьев с крупными дуплами, может размножаться как бородатая неясыть на вершинах "обломышей", или же в гнезАовых постройках хишных птиц (Карякин, 1998; Пукинский, 2005a; König, Weick, 2008).

Изучение дминнохвостых неясытей, помеченных радиопередатчиками, в

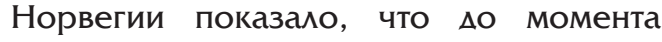
вспугивания, совы наблюдались на присалах, высотой 2,5-8 м, в среднем 5,1 м. FID варьировали от $8 \Delta$ о 35 м, составив в среднем 21 м, и не были связаны с высотой присах. В 11 случаях совы взлетали



Аиннохвостая неясыть (Strix uralensis). Фото И. Карякина.

Ural Owl (Strix uralensis). Photo by I. Karyakin. 

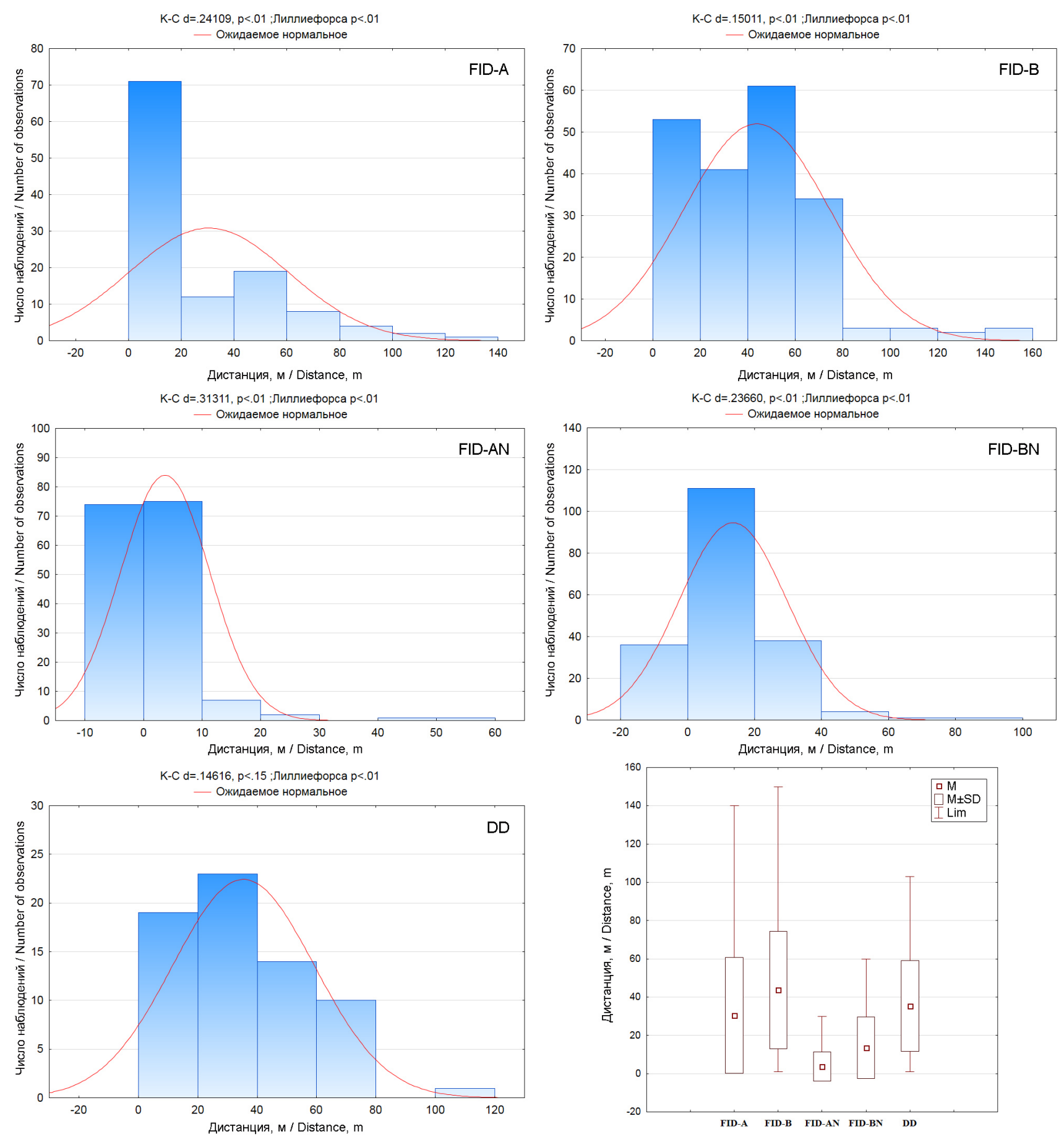

Рис. 26. Аистанции вспугивания (FID) Аииннохвостой неясыти (Strix uralensis): FID-A - $о$ птицы на присаде в период насиживания яиц, FID-B - $\Delta$ птицы на присаце в период выкармливания птенцов, FID-AN - $\Delta$ птицы на гнезде в период насиживания яиц, FID-BN - $\Delta$ о птицы на гнезде в период выкармливания птенцов; DD - Аистанции от гнёзд Аииннохвостой неясыти, Ао края зоны нарушений, на которых гнёзда бросаются птицами.

Fig. 26. Flight initiation distances (FID) for the Ural Owl (Strix uralensis): FID-A - for a bird on a perch during incubation period, FID-B - for a bird on perch during the nestling-rearing period, FID-AN - for a bird in a nest during incubation period, FID-BN - for a bird in a nest during the nestling-rearing period; $D D$ - distances from abandoned nests of the Ural Owl to the edge of the disturbances zones.

Ао того, как были замечены, на расстоянии от 25 Ао 125 м, в среднем 67 м (Аистанции определены с помошью кросстриангуляции). В 9 случаях наблюдатели обошли кругом неясытей, которые не взлетели, оставшись сидеть на присадах, с самым коротким расстоянием $\Delta$ о них от
8 до 45 м, в среднем 19 м. В 6 случаях неясти не взлетали и не проявляли беспокойства, когАа наблюдатели походили на расстоянии 30-100 м, в среднем в 59 м от них (Solheim et al., 2017).

По нашим данным показатели FID ммя мииннохвостых неясытей вне гнёзд в пе- 
риоА насиживания яиц составили в среднем $(n=117)$ $30,38 \pm 30,26$ м (1-140 м, медиана - 15 м, мода - 50 м), в период выкармливания птенцов - $(n=200) \quad 43,81 \pm 30,70 \mathrm{M}$ (1-150 м, медиана - 45 м, мода - 50 м) (рис. 26). Аистанция вспугивания птиц с гнёзА в период киахки составила (n=160) 3,70 \pm 7,60 м (0-60 м, медиана - 1 м, мода - 0 м), в период выкармиивания птенцов - $(n=191) 13,56 \pm 16,12$ (0100 м, медиана - 8 м, мода О м). Не взлетели при проходе наблюдателей под гнездом $46,25 \%$ птиц на киамках из 160 , а $40,62 \%$ взлетели с Аистанции менее 10 м; с гнёзА с птенцами не взлетели 38,74 \% птиц из 191 при проходе поА гнездом, а 34,03 \% птиц покинули гнёзда с Аистанции

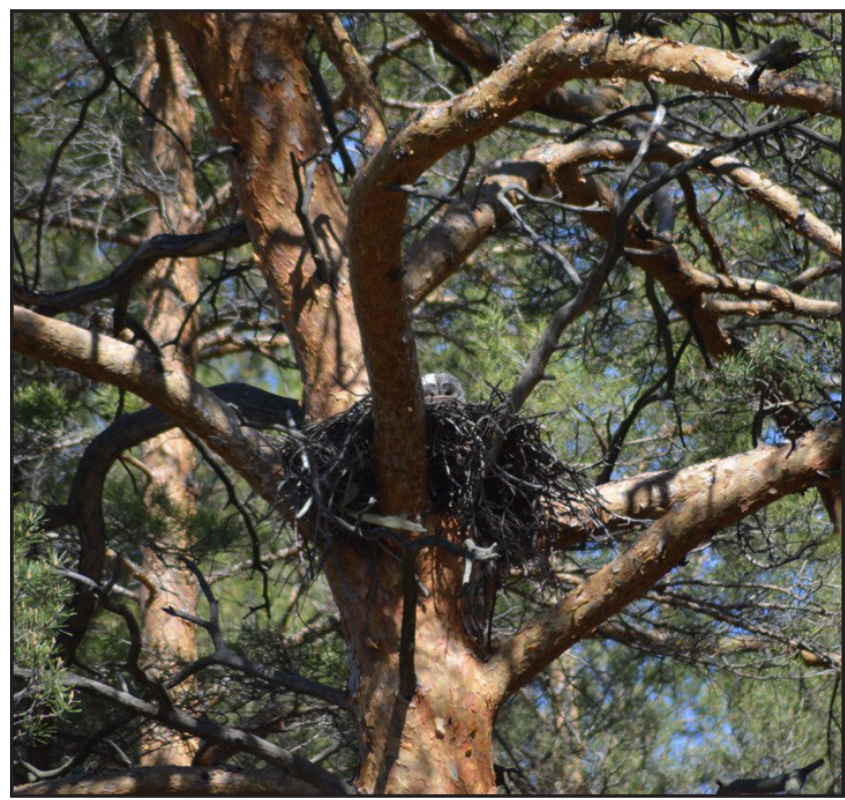

Аиннохвостая неясыть в гнезце, устроенном на сосне в постройке чёрного коршуна. Фото И. Карякина.

Ural Owl in the nest constructed by a Black Kite on the pine tree. Photo by I. Karyakin.
Аальние Аистанции вспугивания неясытей с гнёзд относятся к открытым гнёздам, хотя в ряде случаев при подходе наблюдателей птицы покидами и дупла и гнездовые ящики, что наиболее часто регистрировалось в Самарской области (Карякин и мр., 2009a).

Средняя Аистанция от гнезда Алиннохвостой неясыти $А$ края зоны нарушений, на которой гнезАо осталось жилым, составмяет $(n=11) \quad 74,18 \pm 19,55$ м (40-100 м), при средней дистанции DD, на которой гнёзда оказались брошенными - $(n=67)$ 35,39 $\pm 23,83$ м, от 1 Ао 103 м (рис. 26). $\Delta$ истанции от брошенных гнёзА $\Delta$ края спиошных рубок варьироваии от 15 Ао 70 м, составив в среднем $(n=5) 52,6 \pm 21,63 \mathrm{~m}$, АО выборочных рубок - от 1 АО 103 м, в среднем $(n=56)$ 32,96 23,79 м, Ао минейных нарушений, таких как трасса, АЭП и осушительный канал - от 5 Ао 65 м, в среАнем (n=6) 43,67 21,21 м. На дистанции Ао 40 м от гнезда $А$ края зоны нарушения все гнёзда неясытей оказамись брошенными, исходя из большого числа, опасная зона, в которой вероятность оставления гнезда высока, составляет 40-105 м. Аалее 105 м от гнезда мииннохвостая неясыть терпимо относится к нарушениям, связанным с рубкой леса.

В Венгрии мяя Аминнохвостой неясыти предлагается бурерная зона радиусом 100 м (3,14 га) с запретом мюбых продолжительных нарушений и 100-200 м (3,14-
12,56 га) - с запретом беспокойства в период с 1 февраля по 15 июля (Pongracz, Horvath, 2010). В Великобритании мия близкого вида - серой неясыти (Strix aluco) предложены бусерные зоны вокруг гнёзА ралиусом 80-125 м (Petty, 1998).

Согласно нашим исследованиям, обоснованный радиус бусерной зоны вокруг гнезда Аминнохвостой неясыти Аолжен быть не менее 72 м (табл. 5), в оптимальном варианте - 144 м. Так как мииннохвостая неясыть во время размножения занимает постройки канюка, коршуна и тетеревятника размером от 0,4 $\Delta$ о $1 \mathrm{~m}$, то мя стандартизации размеров бусерных зон Аля этой совы, необходимо придерживаться радиуса 300 м, с опрелелёнными послаблениями в режиме (выборочные рубки и рубки ухода) вне гнезАового периода в зоне от 144 Ао 300 м, если иное не предусмотрено регионаиьными Красными книгами.

\section{Закиючение}

Как видно из Аанного обзора, проблема уничтожения мест гнездования хищных птиц не нова и лежит в основе причин сокрашения численности популяций многих лесных видов, как в России, так и за рубежом. Ааже в европейских странах, гле лесопользователи всегла достаточно серьёзно относились к природоохранному законодательству, наблюдалось регумярное уничтожение гнёзА хишных птиц 
в ходе рубок. Например, на небольшой территории в Нилерландах, только за один 1998 г. рубками были уничтожены 2,5\% гнёзА тетеревятников (14 из 559), 0,5 \% гнёзд перепелятников (3 из 569), 1,3 \% гнёзд канюков (17 из 1327) и 0,9; гнёзд чеглоков (1 из 117) (Bijlsma, 1999). Анамогичные масштабы разрушения гнёзд были отмечены и в Финляндии (Santangeli et al., 2012). ОАнако, негативную тенденцию удалось переломить, вовлекая лесопользователей в программы Аобровольного сохранения гнёзА хишных птиц. В частности, в Северной Карелии лесопользователям преллагаАось Аобровольно вылелить буферы вокруг гнёзд тетеревятника, канюка и осоеда в осваиваемых ими лесах. Участие основывалось на самомотивации, без какого-либо фринансового стимулирования. Участие в программе оказалось очень высоким - к ней в 2002-2006 гг. присоединились $97 \%$ из 327 лесопользователей. Это положительно сказалось на сохранении гнёзд хишных птиц - их потеря в ходе рубок леса уменьшилась с $54 \%$ в 1990-е годы $(n=327$ известных гнёза) $\Delta$ в всего $2 \%$ с начала программы ( $n=519$ гнёзА) (Santangeli et al., 2012). Это очень обнадёживаюшая инсормация, которая позволяет надеяться, на то, что и в России когАа-нибудь подобное станет возможным. Хорошим механизмом в реализации подобных программ может стать процесс Аобровольной лесной сертисрикации по стандартам FSC ${ }^{150}$, к которому уже сейчас присоединяются некоторые лесопользователи.

\section{Благодарности}

Авторы благодарят всех участников экспедиций, в ходе которых был собран материал ция данного исследования, особенно Ринура Бекмансурова, Алексея Вагина, Сергея Важова, Аюдмилу Зиневич, Михаила Кожевникова, Романа Аапшина, Алексея Левашкина, Ольгу Смагину, Амитрия Штоля и Елену Шнайдер. Большая часть экспедиций выполнена в рамках проектов Российской сети изучения и охраны пернатых хишников, программ МБОО "Сибирский экологический центр" и АКО "Геблеровское экологическое обшество", подАержанных ГГФ, Аһьянсом «Экоде^о», Русским географическим обшеством (проект "Орлы России") и Алтае-Саянским отделением ВВФ.

\section{Митература}

Апарова И.И. Гнездование ястреба-тетеревятника в городском лесопарке. - Ястреб-тетеревятник: место в экосистемах России. Материалы к IV консеренции по хишным птицам Северной Евразии. Пенза, 1-3 февраяя 2003 г. / Ред. В.П. Белик. Пенза-Ростов, 2003. С. 1315. [Aparova I.I. Nesting of goshawk in urban forest park. - Goshawk: Position in ecosystems of Russia. Materials of the $4^{\text {th }}$ North-Eurasian Conference on Raptors, Penza, Russia, 1-3 February 2003 / V.P. Belik (Ed.). Penza-Rostov, 2003: 13-15 (in Russian).]. URL: http://rrrcn.ru/ru/archives/22457 Аата обрашения: 12.12.2017.

Бабушкин М.В., Кузнецов А.В. Первая попытка формирования на Рыбинском водохранилише гнездовой группировки скопы, толерантной к фактору беспокойства. - Изучение и охрана хишных птиц Северной Евразии: Материалы V международной консеренции по хищным птицам Северной Евразии. Иваново, 4-7 февраля 2008 г. - Иваново: Иван. гос. ун-т, 2008. C. 32-33. [Babushkin M.V., Kuznetsov A.V. The first attempt of developing of the Osprey nesting group tolerant to human disturbance round Rybinsk Reservoir. - Research and Conservation of the Raptors in Northern Eurasia: Materials of the 5th Conference on Raptors of Northern Eurasia Ivanovo, 4-7 February 2008. Ivanovo, 2008: 32-33 (in Russian).]. URL: http://rrrcn.ru/ru/archives/11205 Аата обрашения: 12.12.2017.

Бабушкин М.В., Кузнецов А.В. Современная численность и распределение гнездовых группировок скопы и орлана-белохвоста на северо-запаце России. - Пернатые хишники и их охрана. 2013. № 27. C. 32-39. [Babushkin M.V., Kuznetsov A.V. The Current Number and Distribution of the Osprey and the White-Tailed Eagle Nestings Groups in North West Russia. - Raptors Conservation. 2013. 27: 32-39.]. URL: http://rrrcn.ru/ru/ archives/21127 Аата обрашения: 12.12.2017.

Бакка С.В. Скопа - Pandion haliaetus L. Красная книга Нижегородской области. Том 1. Животные. 2-е изА. перераб. и доп. Нижний Новгород: АЕКОМ, 2014а. С. 99-100. [Bakka S.V. Osprey - Pandion haliaetus L. - Red Data Book of the Nizhniy Novgorod region. Vol. 1. Animals. Second edition. Nizhniy Novgorod, 2014a: 99-100 (in Russian).]. URL: http://mineco-nn.ru/File/okr_sreda/Krasnay_kniga-2014-2. pdf Аата обрашения: 12.12.2017.

Бакка С.В. Большой подорлик - Aquila clanga Pall. - Красная книга Нижегородской области. Том 1. Животные. 2-е изА. перераб. и Аоп. Нижний Новгород: $\triangle$ ЕКОМ, 2014b. C. 104-105. [Bakka S.V. Greater Spotted Eagle Aquila clanga Pall. - Red Data Book of the Nizhniy Novgorod region. Vol. 1. Animals. Second edition. Nizhniy Novgorod, 2014b: 104-105 (in Russian).]. URL: http://mineco-nn.ru/File/ okr_sreda/Krasnay_kniga-2014-2.pdf Аата обрашения: 12.12.2017. 
Бакка C.B. Беркут - Aquila chrysaetos L. - Красная книга Нижегородской области. Том 1. Животные. 2-е изА. перераб. и АОп. Нижний Новгород: $\triangle$ ЕКОМ, 2014с. С. 107-108. [Bakka S.V. Golden Eagle - Aquila chrysaetos L. - Red Data Book of the Nizhniy Novgorod region. Vol. 1. Animals. Second edition. Nizhniy Novgorod, 2014c: 107-108 (in Russian).]. URL: http://mineco-nn.ru/File/okr_sreda/Krasnay_ kniga-2014-2.pdf Аата обрашения: 12.12.2017.

Бакка С.В. Орлан-белохвост - Haliaeetus albicilla L. Красная книга Нижегородской области. Том 1. Животные. 2-е изА. перераб. и доп. Нижний Новгород: $\triangle$ ЕКОМ, 2014d. C. 108-109. [Bakka S.V. White-Tailed Eagle - Haliaeetus albicilla L. - Red Data Book of the Nizhniy Novgorod region. Vol. 1. Animals. Second edition. Nizhniy Novgorod, 2014d: 108109 (in Russian).]. URL: http://mineco-nn.ru/File/okr_sreda/ Krasnay_kniga-2014-2.pdf Аата обрашения: 12.12.2017.

Бакка С.B. Филин - Bubo bubo L. - Красная книга Нижегородской области. Том 1. Животные. 2-е изд. перераб. и АОП. Нижний Новгород: $\triangle \mathrm{EKOM,} \mathrm{2014е.} \mathrm{С.} \mathrm{143-144.} \mathrm{[Bakka}$ S.V. Eagle Owl - Bubo bubo L. - Red Data Book of the Nizhniy Novgorod region. Vol. 1. Animals. Second edition. Nizhniy Novgorod, 2014e: 143-144 (in Russian).]. URL: http:// mineconn.ru/File/okr_sreda/Krasnay_kniga-2014-2.pdf $\Delta$ ата обрашения: 12.12.2017.

Бакка С.В., Бакка А.И., Левашкин А.П. Бородатая неясыть - Strix nebulosa J.R. Forst. - Красная книга Нижегородской области. Том 1. Животные. 2-е изд. перераб. и Аоп. Нижний Новгород: $\triangle$ ЕКОМ, 2014. С. 148-149. [Bakka S.V., Bakka A.I., Levashkin A.P. Great Grey Owl - Strix nebulosa J.R. Forst. - Red Data Book of the Nizhniy Novgorod region. Vol. 1. Animals. Second edition. Nizhniy Novgorod, 2014: 148-149 (in Russian).]. URL: http://mineco-nn.ru/ File/okr_sreda/Krasnay_kniga-2014-2.pdf Аата обрашения: 12.12.2017.

Бакка С.В., Карякин И.В., Москамик А.Н. Первый сиучай гнездования скопы на опоре АЭП в Поволжье, Россия. Пернатые хишники и их охрана. 2008. № 11. С. 76. [Bakka S.V., Karyakin I.V., Moskalik L.N. The First Record of the Osprey Breeding on the Electric Pole in Povolzhye, Russia. - Raptors Conservation. 2008. 11: 76.]. URL: http://rrrcn.ru/ ru/archives/25034 Аата обрашения: 12.12.2017.

Бакка С.В., Киселёва Н.Ю. Орлан-белохвост в Нижегородской области, Россия. - Пернатые хишники и их охрана. 2009. № 13 C. 21-27. [Bakka S.V., Kiseleva N.Yu. The White-Tailed Eagle in the N. Novgorod District, Russia - Raptors Conservation. 2009. 13: 21-27.]. URL: http://rrrcn.ru/ru/ archives/24900 Аата обрашения: 12.12.2017.

Бакка С.В., Киселёва Н.Ю. Орёл-карлик - Hieraaetus pennatus Gmel. - Красная книга Нижегородской области. Том 1. Животные. 2-е изд. перераб. и доп. Нижний Новгоpos: $\triangle$ EKOM, 2014. C. 103-104. [Bakka S.V., Kiseleva N.Yu. Booted Eagle - Hieraaetus pennatus Gmel. - Red Data Book of the Nizhniy Novgorod region. Vol. 1. Animals. Second edition. Nizhniy Novgorod, 2014: 103-104. (in Russian).]. URL: http://mineco-nn.ru/File/okr_sreda/Krasnay_kniga-2014-2. pdf Аата обрашения: 12.12.2017.

Бахтин Р.Ф. Чёрный коршун в антропогенных ландшастах. Аитайская гос. акацемия обр-я им. В.М. Шукшина. Бийск: ФГБОУ ВПО "АГАО", 2013. 123 с. [Bachtin R.F. Black Kite in anthropogenic landscapes. Shukshin Altai State Academy of Education. Biysk, 2013: 1-123 (in Russian).]. URL: http://rrrcn.ru/ru/archives/27843 Аата обрашения: 12.12.2017.

Бахтин Р.Ф. Гнездовые предпочтения чёрного коршуна в лесополосах Алтайского края, Россия. - Пернатые хишники и их охрана. 2016. № 32. C. 49-58. [Bachtin R.F. Breeding ecology of the Black Kite in forest shelter belts of Altai Kray, Russia. - Raptors Conservation. 2016. 32: 49-58.] DOI: 10.19074/1814-8654-2016-32-49-58 URL: http://rrrcn.ru/ ru/archives/26932 Аата обрашения: 12.12.2017.

Бахтин Р.Ф., Важов С.В. Воробьиный сыч Glaucidium passerinum (Linnaeus, 1758). - Красная книга Алтайского края. Том 2. Редкие и находяшиеся под угрозой исчезновения виды животных. Барнаул, 2016. С. 228-229. [Bachtin R.F., Vazhov S.V. Eurasian Pygmy Owl - Glaucidium passerinum (Linnaeus, 1758). - Red Data Book of the Altai Kray. Vol. 2. Rare and endangered species of animals. Barnaul, 2016: 228229. (in Russian).]. URL: http://altaipriroda.ru/krasnaja_kniga Аата обрашения: 12.12.2017.

Бахтин Р.Ф., Важов С.В., Макаров А.В. Экология синантропной популяции чёрного коршуна в окрестностях Бийска, Алтайский край, Россия. - Пернатые хишники и их охрана. 2010. № 20. C. 68-83. [Bachtin R.F., Vazhov S.V., Makarov A.V. Ecology of Synanthropic Populations of the Black Kite in the Vicinities of Biysk, Altai Kray, Russia. - Raptors Conservation. 2010. 20: 68-83.]. URL: http://rrrcn.ru/ru/ archives/19240 Аата обрашения: 12.12.2017.

Бекмансуров Р.Х., Аюпов А.С., Карякин И.В., Костин Е.С. Результаты мониторинга гнездовых группировок орлана-белохвоста на некоторых особо охраняемых и прилегаюших к ним природных территориях в Республике Татарстан в 2012 году, Россия. - Пернатые хишники и их охрана. 2012. № 25. C. 79-96. [Bekmansurov R.H., Ayupov A.S., Karyakin I.V., Kostin E.S. Results of the Monitoring of the White-Tailed Eagle Populations in Some Protected Areas and Adjacent Territories in the Republic of Tatarstan in 2012, Russia. - Raptors Conservation. 2012. 25: 79-96.]. URL: http://rrrcn.ru/ru/archives/19107 Аата обрашения: 12.12.2017.

Белик В.П. Тетеревятник в степном Придонье: распространение и экология. - Ястреб-тетеревятник: место в экосистемах России. Материамы к IV конференции по хишным птицам Северной Евразии. Пенза, 1-3 февраия 2003 г. / Ред. В.П. Белик. Пенза-Ростов, 2003. С. 15-48. [Belik V.P. Goshawks in the steppe part of Don region: distribution and ecology. - Goshawk: Position in ecosystems of Russia. Materials of the $4^{\text {th }}$ North-Eurasian Conference on Raptors, Penza, Russia, 1-3 February 2003 / V.P. Belik (Ed.). Penza-Rostov, 2003: 15-48 (in Russian).]. URL: http://rrrcn.ru/ru/archives/22457 Аата обрашения: 12.12.2017.

Белик В.П. Освоение орланом-белохвостом новой ацаптации к гнездованию на опорах АЭП. - Байкаиьский зоомогический журнал. 2013. № 2 (13). C. 5-7 [Belik V.P. The familiarization of White-Tailed Eagle to the new adaptation to the nestling at the poles of power lines. - Baikal zoological magazine. 2013. № 2 (13): 5-7 (in Russian)]. URL: http:// rbcu.ru/news/26804 Аата обрашения: 12.12.2017.

Белик В.П. Орёл-могильник, или карагуш Aquila heliaca Savigny, 1809. - Красная книга Ростовской области: Издание 2-е. Т. 1. Животные. Ростов-на-Аону: Минприроды Ростовской области, 2014. С. 1006-1011. [Электронный pecypc]. [Belik V.P. Imperial Eagle Aquila heliaca Savigny, 1809. - Red Data Book of the Rostov Region: Second Edition. T. 1. Animals. Rostov-on-Don: Ministry of Environment of the Rostov Region, 2014: 1006-1011. [Electronic resource] (in Russian)]. URL: http://минприродыро. pcp/upload/iblock/758/Volume1.pdf Аата обрашения: 12.12.2017.

Березовиков Н.Н. Основные факторы, мимитирующие численность беркута в Казахстане. - Охота с мовчими птицами: история и современность. Материалы Международ- 
ной научно-практической консеренции / под реА. A.M. Мемдебекова. Амматы:, 2017. С. 54-60. [Berezovikov N.N. The main factors limiting the population numbers of Golden Eagles in Kazakhstan. - Hunting with birds of prey: history and contemporaneity. Articles of the International Scientific and practical Conference / A.M. Meldebekov et al. Eds. Almaty, 2017: 54-60.]. URL: http://rrrcn.ru/ru/archives/29782 $\triangle$ ата обрашения: 12.12.2017.

Важов С.В. Некоторые особенности экологических ниш пернатых хишников в российской части предгорий Алтая. - Пернатые хишники и их охрана. 2012. № 25. С. 115125. [Vazhov S.V. Some Features of the Ecological Niches of Raptors in the Russian Part of the Altai Foothills. - Raptors Conservation. 2012. 25: 115-125]. URL: http://rrrcn.ru/ru/ archives/19118 Аата обрашения: 12.12.2017.

Важжов С.В., Бахтин Р.Ф. Большой подорлик - Aquila clanga Pallas, 1811. - Красная книга Аитайского края. Том 2. РеАкие и находяшиеся под угрозой исчезновения виды животных. Барнаул, 2016а. C. 157-159. [Vazhov S.V., Bachtin R.F. Greater Spotted Eagle - Aquila clanga Pallas, 1811. - Red Data Book of the Altai Kray. Vol. 2. Rare and endangered species of animals. Barnaul, 2016a: 157-159. (in Russian).]. URL: http://altaipriroda.ru/krasnaja_kniga $\triangle$ ата обрашения: 12.12.2017.

Важов С.В., Бахтин Р.Ф. Беркут - Aquila chrysaetos (Linnaeus, 1758). - Красная книга А^тайского края. Том 2. Редкие и находяшиеся под угрозой исчезновения виды животных. Барнаул, 2016b. С. 162-164. [Vazhov S.V., Bachtin R.F. Golden Eagle - Aquila chrysaetos (Linnaeus, 1758). Red Data Book of the Altai Kray. Vol. 2. Rare and endangered species of animals. Barnaul, 2016b: 162-164. (in Russian).]. URL: http://altaipriroda.ru/krasnaja_kniga Аата обрашения: 12.12.2017.

Важжо С.В., Бахтин Р.Ф. Орлан-белохвост - Haliaeetus albicilla (Linnaeus, 1758). - Красная книга А^тайского края. Том 2. Редкие и находяшиеся под угрозой исчезновения виды животных. Барнаул, 2016с. С. 165-167. [Vazhov S.V., Bachtin R.F. White-Tailed Eagle - Haliaeetus albicilla (Linnaeus, 1758). - Red Data Book of the Altai Kray. Vol. 2. Rare and endangered species of animals. Barnaul, 2016c: 165167. (in Russian).]. URL: http://altaipriroda.ru/krasnaja_kniga Аата обрашения: 12.12.2017.

Важов С.В., Бахтин Р.Ф. Филин - Bubo bubo (Linnaeus, 1758). - Красная книга Алтайского края. Том 2. РеАкие и находяшиеся под угрозой исчезновения виды животных. Барнаул, 2016d. C. 225-227. [Vazhov S.V., Bachtin R.F. Eagle Owl - Bubo bubo (Linnaeus, 1758). - Red Data Book of the Altai Kray. Vol. 2. Rare and endangered species of animals. Barnaul, 2016d: 225-227. (in Russian).]. URL: http://altaipriroda.ru/krasnaja_kniga Аата обрашения: 12.12.2017

Важжов С.В., Бахтин Р.Ф. Бородатая неясыть - Strix nebulosa Forster, 1772. - Красная книга Аитайского края. Том 2. Редкие и находяшиеся под угрозой исчезновения виды животных. Барнаул, 2016е. С. 229-231. [Vazhov S.V., Bachtin R.F. Great Grey Owl - Strix nebulosa Forster, 1772. Red Data Book of the Altai Kray. Vol. 2. Rare and endangered species of animals. Barnaul, 2016e: 229-231. (in Russian).]. URL: http://altaipriroda.ru/krasnaja_kniga Аата обрашения: 12.12.2017.

Важов С.В., Бахтин Р.Ф., Петров В.Ю. Могильник - Аquila heliaca Savigny, 1809. - Красная книга Аитайского края. Том 2. Редкие и находяшиеся под угрозой исчезновения виды животных. Барнаул, 2016. С. 159-161. [Vazhov S.V., Bachtin R.F., Petrov V.Yu. Eastern Imperial Eagle - Aquila heliaca Savigny, 1809. - Red Data Book of the Altai Kray. Vol. 2.
Rare and endangered species of animals. Barnaul, 2016: 159161. (in Russian).]. URL: http://altaipriroda.ru/krasnaja_kniga Аата обрашения: 12.12.2017.

Важов С.В., Рыбаиьченко А.В. Результаты мониторинга некоторых гнездовых участков филина в Аитайском крае в 2012 г., Россия. - Пернатые хишники и их охрана. 2013. № 26. C. 109-115 [Vazhov S.V., Rybalchenko D.V. Monitoring Results for Some Breeding Territories of the Eagle Owl in the Altai Kray in 2012, Russia. - Raptors Conservation. 2013. 26: 109-115]. URL: http://rrrcn.ru/ru/archives/19597 Аата обрашения: 12.12 .2017$.

Витер С.Г. Распространение и особенности биологии орлана-белохвоста (Haliaeetus albicilla) в $\Delta$ непромежнуречье. - Байкальский зоологический журнал. 2013. № 2 (13). C. 16-23. [Viter S.G. The spread and peculiarities of biology of White-Tailed Eagle (Haliaeetus albicilla) in Dnepr and Don rivers. - Baikal zoological magazine. 2013. 2 (13): 16-23 (in Russian)]. URL: http://www.rbcu.ru/information/1883/26803 Аата обрашения: 12.12.2017.

Витер С.Г. "Гнездовой консерватизм" (верность месту), лесное хозяйство и стратегия охраны хишных птиц в Украине. - Пернатые хищники и их охрана. 2014. № 29. С. 39-51. [Viter S.G. A Site Fidelity, Forestry and Raptor Conservation in Ukraine. - Raptors Conservation. 2014. 29: 3951.] DOI: 10.19074/1814-8654-2014-29-39-51 URL: http:// rrrcn.ru/ru/archives/25757 Аата обрашения: 12.12.2017.

Вуолкер А.Г. Аают ми предположения относительно экомогии беркута (Aquila chrysaetos) налёжные рекомендации мля регулирования этого вида? - Орлы Палеарктики: изучение и охрана - тезисы международной научно-практической консеренции, Елабуга (Татарстан, Россия), 20-23 сентября 2013 г. / реА. А.А. Каюмов, И.В. Карякин, Э.Г. Николенко, Е.П. Шнайдер. Елабуга, 2013. С. 26. [Walker D.G. Do expectations about Aquila chrysaetos ecology produce reliable guidance for species management? - Eagles of Palearctic: Study and Conservation - Abstracts of the International Scientific and Practical Conference, Elabuga, Tatarstan Republic, Russia, 20-23 September 2013 / Eds. A.A. Kayumov, I.V. Karyakin, E.G. Nikolenko, E.P. Shnayder. Elabuga, 2013: 26]. URL: http://rrrcn.ru/ru/archives/19978 $\Delta$ ата обрашения: 12.12.2017.

Гаврилюк М.Н. Орлан-белохвост в Украине: современное состояние, биология и охрана. Автореферат диссертации на соискание ученой степени кандидата биологических наук. Киев, 2002. 16 с. [Gavrilyuk M.N. The White-tailed Eagle in Ukraine: current status, biology and protection. Thesis for a candidate degree of biological science. Kiev, 2002: 1-16. (In Ukrainian).]. URL: http://base.dnsgb.com.ua/files/ ard/2002/02gmnsbo.pdf Аата обрашения: 12.12.2017.

Гаврилюк М.Н. Изменение численности орлана-белохвоста на территории Украины в XX ст. и возможные их причины. - Беркут. 2004. Т. 13, вып. 2. С. 205-225. [Gavrilyuk M.N. Population trends of the White-Tailed Eagle in Ukraine during $\mathrm{XX}$ century and probable their reasons. - Berkut. 2004. 13(2): 205-225. (in Russian).]. URL: http://www.aetos. kiev.ua/berkut/berkut13-2/ecology13-2-4.pdf Аата обрашения: 12.12.2017.

Гаврилюк М.H. Орлан-білохвіст Haliaeetus albicilla (Linnaeus, 1758). - Червона книга України. Тваринний світ/ за ред. І.А. Акімова. Київ: Глобалконсаитинг, 2009. С. 432. [Gavrilyuk M.N. White-Tailed Eagle Haliaeetus albicilla (Linnaeus, 1758). - Red Data Book of Ukraine. Animals / ed. I.A. Akimov. Kiev, 2009: 432. (in Ukrainian)]. URL: http:// redbook-ua.org/ru/item/haliaeetus-albicilla-linnaeus/ $\Delta$ aта обрашения: 12.12.2017. 
Гаврилюк М. Н., Гришенко В. М. Продуктивність розмноження орлана-білохвоста (Haliaeetus albicilla (L.)) в Україні в 1988-2008 рр. - Новітні дослідження соколоподібних та сов. Матеріали III Міжнародної наукової консеренції "Хижі птахи України", м. Кривий Ріг, 24-25 жовтня 2008 р. Кривий Ріг, 2008. С. 79-85. [Gavrilyuk M.N., Grishchenko V.M. Breeding productivity of the White-Tailed Eagle (Haliaeetus albicilla (L.)) in Ukraine in 1988-2008. - Modern Study of Birds of Prey and Owls. Materials of III International Scientific Conference "Birds of Prey and Owls of Ukraine". Kryvyi Rih, 24-25 October 2008. Kryvyi Rih, 2008: 79-85 (in Ukrainian).]. URL: https://raptors.org.ua/ru/wp-content/files/ KrR2008_79-85.pdf Аата обрашения: 12.12.2017.

Галушин В.М. Адаптация хишных птиц к современным антропогенным воздействиям. - Зоологический журнац. 1982. 61 (7). C. 1088-1096. [Galushin V.M. Adaptation of birds of prey to modern anthropogenic influences. - Zoological journal. 1982. 61 (7): 1088-1096.].

Гаиушин В.М. Беркут Aquila chrysaetos (Linnaeus, 1758). - Красная книга Российской Федерации (животные). М., 2001. C. 440-442. [Galushin V.M. Golden Eagle Aquila chrysaetos (Linnaeus, 1758). - Red Data Book of Russian Federation (animals). Moscow, 2001: 440-442 (in Russian).]. URL: http://biodat.ru/db/rb/rb.php?src=1\&vid=283 $\triangle$ ата обрашения: 12.12.2017.

Ганусевич С.А. Скопа Pandion haliaetus (Linnaeus, 1758). - Красная книга Российской Федерации (животные). М., 2001. C. 421-423. [Ganusevich S.A. Osprey Pandion haliaetus (Linnaeus, 1758). - Red Data Book of Russian Federation (animals). Moscow, 2001: 421-423 (in Russian).]. URL: http://biodat.ru/db/rb/rb.php?src=1\& vid=271 Аата обрашения: 12.12.2017

ГейАаров П.Ш. Алгоритм определения расположения и размеров объектов на основе анализа изображений объектов. - Компьютерная оптикаю 2011. Том 35, № 2. C. 275-280. [Geidarov P.S. Algorithm for determining the location and dimensions of objects based on analysis of image objects. - Computer Optics. 2011. 35(2): 275-280 (in Russian).]. URL: http://www.computeroptics.smr.ru/KO/PDF/ КО35-2/21.pdf Аата обрашения: 12.12.2017.

Грибков А. Заказники - под топор? - Российская сеть изучения и охраны пернатых хишников. 2014 [Gribkov A. Nature Reserves - under axe? - Russian Raptor Research and Conservation Network. 2014 (in Russian).]. URL: http://rrrcn. ru/ru/archives/19850 Аата обрашения: 12.12.2017.

Гринченко О.С., Волков С.В., Макаров А.В. Современное состояние и тенденции изменения численности и распространения большого и малого подорликов в Аубненской низменности, Московская область. - Изучение и охрана большого и малого подорликов в Северной Евразии: Материаиы к V международной конференции по хишным птицам Северной Евразии, Иваново, 4-7 февраия 2008 г. / РеА. В.Н. Мельников, В.Ч. Аомбровский, А.А. Мишенко. Иваново: Ивановский государственный университет, 2008. С. 72-74. [Grinchenko O.S., Volkov S.V., Makarov A.V. Current status, number and distribution trends of Great and Lesser Spotted Eagle in Dubna lowland, Moscow region. - Research and Conservation of the Greater Spotted Eagle and Lesser Spotted Eagle in Northern Eurasia: Proceedings of the V International Conference on Raptors of Northern Eurasia, Ivanovo, 4-7 February 2008 r. / Eds. V.N. Melnikov, V.Ch. Dombrovskiy, A.L. Mischenko. Ivanovo, 2008: 72-74 (in Russian).]. URL: http://rrrcn. ru/ru/archives/11198 Аата обрашения: 12.12.2017.

Гришанов Г.В., Аысанский И.Н. Орлан-белохвост Haliaeetus albicilla в Камининграхской области. - Байкаль- ский зоологический журнал. 2013. № 2 (13). С. 24-28. [Grishanov G.V., Lisanskiy I.N. White-Tailed Eagle Haliaeetus albicilla in Kaliningrad region. - Baikal zoological magazine. 2013. 2 (13): 24-28 (in Russian)]. URL: http://rbcu.ru/ news/26804 Аата обрашения: 12.12.2017.

Громазин О.А., Филимонов А.В., Погорский Н.В., Шишалов И.С. Способ определения расстояния до объекта при помоши камеры (варианты). Патент RU 2602729. Влацелец патента: ООО "АиСиКон". - Google Patents. 2014. [Gromazin O.A., Filimonov A.V., Pogorsky N.V., Shishalov I.S. Method of distance to object determining by means of camera (versions). Patent RU 2602729. The owner of the patent: DiCiCon LLC.- Google Patents. 2014.]. URL: https://patents.google.com/patent/RU2602729C2/ ru $\triangle$ ата обрашения: 12.12 .2017 .

Ажамирзоев Г.С., Букреев С.А., Бархалов Р.М., Мазанаева А.Ф., Яровенко Ю.А., Куниев К.М., Плакса С.А., Перевозов А.Г., Газарян С.В., Аскендеров А.А., Насрулаев Н.И., Бабаев Э.А., Яровенко А.Ю. Редкие позвоночные животные заповедника "Аагестанский" / Под ред. Г.С. Ажамирзоева и С.А. Букреева. - Труды заповедника "Аагестанский». Вып. 6. Махачкала, 2013. 372 с. [Dzhamirzoev G.S., Bukreev S.A., Barkhalov R.M., Mazanaeva L.F., Yarovenko Yu.A., Kuniev K.M., Plaksa S.A., Perevozov A.G., Gazaryan C.V., Askenderov A.D., Nasrulaev N.I., Babaev E.A., Yarovenko A.Yu. Rare vertebrate animals of the Dagestan State Nature Reserve / Eds. G.S. Dzhamirzoev and S.A. Bukreev. - Proceedings of the Dagestan Reserve. Vol. 6. Makhachkala, 2013: 1-372 (in Russian).]. URL: https://cloud.mail.ru/ public/BvE2/4xTSH1u13 Аата обрашения: 12.12.2017.

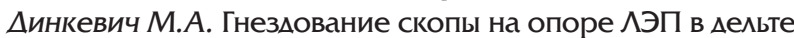
Волги, Астраханская область, Россия. - Пернатые хишники и их охрана. 2011. № 22. С. 198-200. [Dinkevich M.A. Nesting of the Osprey on the Electric Pole in the Volga Delta, Astrakhan District, Russia. - Raptors Conservation 2011. 22: 198-200]. URL: http://rrrcn.ru/ru/archives/12800 Аата обрашения: 12.12 .2017$.

Аомашевський С.В. Подорлик великий Aquila clanga (Pallas, 1811). - Червона книга України. Тваринний світ/ за ред. І.А. Акімова. Київ: ГАобаиконсаитинг, 2009. С. 428. [Domashevskiy S.V. Greater Spotted Eagle Aquila clanga (Pallas, 1811). - Red Data Book of Ukraine. Animals / ed. I.A. Akimov. Kiev, 2009: 428. (in Ukrainian)]. URL: http://redbook-ua.org/ru/item/aquila-clanga-pallas/ $\Delta$ ата обрашения: 12.12.2017.

Аомашевський С.В., Бумар Г.В. Сова бородата Strix nebulosa Forster, 1772. - Червона книга України. Тваринний світ/ за ред. І.А. Акімова. Київ: Глобаиконсаитинг, 2009. С. 469. [Domashevskiy S.V., Bumar G.V. Great Grey Owl Strix nebulosa Forster, 1772. - Red Data Book of Ukraine. Animals / ed. I.A. Akimov. Kiev, 2009: 469. (in Ukrainian)]. URL: http://redbook-ua.org/ru/item/strix-nebulosa-forster/ $\triangle$ Аата обрашения: 12.12.2017.

Аомашевський С.В., Годованець Б.Й. Беркут Aquila chrysaetos (Linnaeus, 1758). - Червона книга України. Тваринний світ/ за ред. І.А. Акімова. Київ: Глобалконсалтинг, 2009. С. 431. [Domashevskiy S.V., Godovanec B.I. Golden Eagle Aquila chrysaetos (Linnaeus, 1758). - Red Data Book of Ukraine. Animals / ed. I.A. Akimov. Kiev, 2009: 431. (in Ukrainian)]. URL: http://redbook-ua.org/ ru/item/aquila-chrysaetos-linnaeus/ $\Delta$ ата обрашения: 12.12.2017.

Аомашевський С.В., Стригунов B.I. Пінорлик маяий Aquila pomarina (C.L. Brehm, 1831). - Червона книга України. Тваринний світ/ за ред. І.А. Акімова. Київ: Глобаиконсаитинг, 
2009. C. 429. [Domashevskiy S.V., Strigunov V.I. Lesser Spotted Eagle Aquila pomarina (C.L. Brehm, 1831). - Red Data Book of Ukraine. Animals / ed. I.A. Akimov. Kiev, 2009: 429. (in Ukrainian)]. URL: http://redbook-ua.org/ru/item/aquilapomarina-c-l-brehm/ Аата обрашения: 12.12.2017.

Аомбровский В.Ч. Результаты мониторинга численности орлов в Беларуси. - Пернатые хишники и их охрана. 2013. № 27. C. 92-101. [Dombrovski V.C. Results of the Monitoring of Eagle Numbers in Belarus. - Raptors Conservation. 2013. 27: 92-101.]. URL: http://rrrcn.ru/ru/archives/21147 $\triangle$ ата обрашения: 12.12 .2017 .

Аомбровский В.Ч., Ивановский В.В. Малый подорлик Aquila pomarina C.L. Brehm, 1831. - Красная книга Республики Беларусь. 2006. [Dombrovski V.C., Ivanovski V.V. Lesser Spotted Eagle Aquila pomarina C.L. Brehm, 1831. - Red Data Book of Republic of Belarus. 2006 (in Russian).]. URL: http://redbook.minpriroda.gov.by/animalsinfo.html?id=37 Аата обрашения: 12.12.2017.

$\triangle$ руп А.И. О заселении ястребами населенных пунктов Центраиьного Предкавказья. - Птицы Южной России: Материалы Международной орнитологической консеренции "Итоги и перспективы развития орнитологии на Северном Кавказе в XXI веке", посвяшенной 20-летию Аеятельности Северо-Кавказской орнитологической группы. Ростов на $\triangle$ ону, 2002. C. 107-108. [Drup A.I. On the occupancy by Goshawks of settlements of the Central Ciscaucasia. - Birds of Southern Russia: Materials of the International Ornithological Conference "Results and Prospects of Ornithology Development in the North Caucasus in the $21^{\text {st }}$ Century", dedicated to the $20^{\text {th }}$ anniversary of the activities of the North Caucasian Ornithological Group. Rostov on Don, 2002: 107-108].

Аруп А.И., ИАьюх М.П. Тетеревятник в Предкавказье. - Ястреб-тетеревятник: место в экосистемах России. Материалы к IV конференции по хишным птицам Северной Евразии. Пенза, 1-3 февраяя 2003 г. / РеА. В.П. Белик. Пенза-Ростов, 2003. С. 62-80. [Drup A.I., Ilyukh M.P. Goshawk in Ciscaucasia. - Goshawk: Position in ecosystems of Russia. Materials of the 4th North-Eurasian Conference on Raptors, Penza, Russia, 1-3 February 2003 / V.P. Belik (Ed.). Penza-Rostov, 2003: 62-80 (in Russian).]. URL: http://rrrcn. ru/ru/archives/22457 Аата обрашения: 12.12.2017.

Ежегодный АокиаА о состоянии и использовании лесов Российской Фелерации в 2011 г. Москва, 2013. 113 с. [Annual report on the state and use of forests of the Russian Federation in 2011. Moscow, 2013: 1-113 (in Russian).]. URL: http://www.mnr.gov.ru/upload/iblock/780/lesarf2011.pdf Аата обрашения: 12.12.2017.

Жимулёв И.Ф., Ананько Н.Г., Андреенков О.В., Костерин О.Э. Распределение гнёзд хишных птиц на территории Новосибирского Академгородка и в его ближайших окрестностях, Россия. - Пернатые хишники и их охрана. 2008. № 11. C. 73-75. [Zhimulev I.F., Ananko N.G., Andreenkov O.V., Kosterin O.E. Distribution of Nests of Birds of Prey in Akademgorodok of Novosibirsk and its Vicinities, Russia. - Raptors Conservation. 2008. 11: 73-75.]. URL: http:// rrrcn.ru/ru/archives/25030 Аата обрашения: 12.12.2017.

Зиневич А.С., Карякин И.В., Шнайдер Е.П., Штоль А.А. Уцелевшие чудом. - Российская сеть изучения и охраны пернатых хишников. 2016. [Zinevich L.S., Karyakin I.V., Shnayder E.P., Shtol D.A. Saved by a Miracle. - Russian Raptor Research and Conservation Network. 2016]. URL: http:// rrrcn.ru/archives/26536 Аата обрашения: 12.12.2017.

Ивановский В.В. Хищные птицы Белорусского Поозерья : монография. Витебск: УО «ВГУ им. П.М. Машерова», 2012.
209 c. [Ivanovski V.V. The Birds of Prey in the Belorussian Poozerie. Vitebsk, 2012: 1-209 (in Russian).]. URL: http:// rrrcn.ru/ru/archives/24498 Аата обрашения: 12.12.2017.

Ивановский В.В. Займёт ки орлан-белохвост Haliaeetus albicilla экологическую нишу беркута Aquila chrysaetos в Северной Белоруссии? - Русский орнитологический журнач. 2014. Т. 23, Вып. 1063: 3331-3341. [Ivanovski V.V. Will be the White-Tailed Eagle Haliaeetus albicilla occupy the ecological niche of Golden Eagle Aquila chrysaetos in Northern Belarus? - Russian Ornithological Journal. 2014. 23(1063): 3331-3341. (in Russian).]. URL: https://cyberleninka.ru/ article/n/zaymyot-li-orlan-belohvost-haliaeetus-albicilla-ekologicheskuyu-nishu-berkuta-aquila-chrysaetos-v-severnoybelorussii Аата обрашения: 12.12.2017.

Ивановский В.В. Исчезнет ли дербник на гнездовании из Северной Белоруссии? - Пернатые хишники и их охрана. 2016. № 32. С. 112-117. [Ivanovsky V.V. Will the Merlin disappear as a breeding species from Northern Belarus? - Raptors Conservation. 2016. 32: 112-117.] DOI: 10.19074/1814-8654-2016-32-112-117 URL: http://rrrcn. ru/ru/archives/26953 Аата обрашения: 12.12.2017.

Ивановский В.В., Аомбровский В.Ч. Орлан-белохвост Haliaeetus albicilla (Linnaeus, 1758). - Красная книга Республики Беларусь. 2006а. [Ivanovski V.V., Dombrovski V.C. White-Tailed Eagle Haliaeetus albicilla (Linnaeus, 1758). - Red Data Book of Republic of Belarus. 2006a (in Russian).]. URL: http://redbook.minpriroda.gov.by/animalsinfo.html?id=34 Аата обрашения: 12.12.2017.

Ивановский В.В., Аомбровский В.Ч. Беркут Aquila chrysaetos (Linnaeus, 1758). - Красная книга Республики Беларусь. 2006b. [Ivanovski V.V., Dombrovski V.C. Golden Eagle Aquila chrysaetos (Linnaeus, 1758). - Red Data Book of Republic of Belarus. 2006b (in Russian).]. URL: http://redbook.minpriroda.gov.by/animalsinfo.html?id=39 Аата обрашения: 12.12.2017.

Ильина О., Карпачевский М., Яницкая Т. Нормативноправовая основа сохранения биоразнообразия при заготовках Аревесины и рекомендации по ее применению. Москва, 2009. 36 с. [Ilyina O., Karpachevsky M., Yanitskaya T. Regulatory and legal basis for biodiversity conservation during the forest harvesting and recommendations for its use. Moscow, 2009: 1-36 (in Russian).]. URL: https://new.wwf. ru/upload/iblock/40f/norm_prav_biodiv.pdf $\triangle$ ата обрашения: 12.12.2017.

Ирисова Н.А. Малый перепелятник - Accipiter gularis (Temminck et Schlegel, 1844). - Красная книга А^тайского края. Том 2. Редкие и находяшиеся под угрозой исчезновения виды животных. Барнаул, 2016а. С. 149-150. [Irisova N.L. Japanese Sparrowhawk - Accipiter gularis (Temminck et Schlegel, 1844). - Red Data Book of the Altai Kray. Vol. 2. Rare and endangered species of animals. Barnaul, 2016a: 149-150. (in Russian).]. URL: http://altaipriroda.ru/ krasnaja_kniga Аата обрашения: 12.12.2017.

Ирисова Н.А. Орёл-карлик - Hieraaetus pennatus (Gmelin, 1788). - Красная книга Алтайского края. Том 2. Редкие и находяшиеся под угрозой исчезновения виды животных. Барнаул, 2016b. С. 154-155. [Irisova N.L. Booted Eagle - Hieraaetus pennatus (Gmelin, 1788). - Red Data Book of the Altai Kray. Vol. 2. Rare and endangered species of animals. Barnaul, 2016b: 154-155. (in Russian).]. URL: http://altaipriroda.ru/krasnaja_kniga Аата обрашения: 12.12.2017.

Качякин М.В., Волцит О.В., Гроот Куркамп Х. Атлас птиц города Москвы / Н.С. Морозов (реА.). М.: "Фитон XXI", 2014. 332 c. [Kalyakin M.V., Voltzit O.V., Groot Koerkamp G. 
Atlas of the birds of Moscow City / N.S. Morozov (ed.). Moscow, 2014: 1-332 (in Russian).].

Карякин И.В. Пернатые хишники Ураиьского региона. Соколообразные (Falconiformes), Совообразные (Strigiformes). Пермь, 1998. 483 с. [Karyakin I.V. Raptors of the Ural region. Birds of prey (Falconiformes), Owls (Strigiformes). Perm, 1998: 1-483 (un Russian).]. URL: http://rrrcn. ru/ru/archives/9173 Аата обрашения: 12.12.2017.

Карякин И.В. Балобан в Волго-Урамьском регионе и на примегаюших территориях. - Степной бюметень. 2004. № 15. C. 32-39. [Karyakin I.V. Saker Falcon in the VolgaUral Region and in the adjacent territories. - Steppe Bulletin. 2004. 15: 32-39 (in Russian).]. URL: http://savesteppe.org/ ru/archives/3350 Аата обрашения: 12.12.2017.

Карякин И.В. Экспансия могильника на АЭП в Западном Казахстане. - Пернатые хишники и их охрана. 2006. № 7. C. 62-64 [Karyakin I.V. Expansion of the Imperial Eagle onto power lines in Western Kazakhstan. - Raptors Conservation. 2005. 7: 62-64]. URL: http://docs.sibecocenter.ru/programs/ raptors/RC07/raptors_conservation_2006_7_pages_62_69. pdf Аата обрашения: 12.12.2017.

Карякин И.В. Орёл-карлик в Поволжье, на Урале и в Сибири, Россия. - Пернатые хишники и их охрана, 2007. № 9. C. 27-62. [Karyakin I.V. The Booted Eagle in the Volga Region, Ural and Siberia, Russia. - Raptors Conservation. 2007. 9: 27-62.]. URL: http://docs.sibecocenter.ru/ programs/raptors/RC09/raptors_conservation_2007_9_pages_27_62.pdf Аата обрашения: 12.12.2017.

Карякин И.В. Большой подорлик в Поволжье, на Урале и в Западной Сибири. - Пернатые хишники и их охрана. 2008a. № 11. C. 23-69. [Karyakin I.V. The Greater Spotted Eagle in the Volga Region, Ural Mountains and Western Siberia. - Raptors Conservation. 2008. 11: 23-69.]. URL: http:// rrrcn.ru/ru/archives/25020 Аата обрашения: 12.12.2017.

Карякин И.В. Проблема “Птицы и АЭП»: есть и положительный аспект. - Пернатые хищники и их охрана. 2008b. № 12. C. 11-27 [Karyakin I.V. Problem "Birds and Power Lines": Some Positive Effects Exist. - Raptors Conservation. 2008. 12: 11-27]. URL: http://rrrcn.ru/ru/archives/24950 $\triangle$ ата обрашения: 12.12.2017.

Карякин И.В. Особенности экологии большого подорлика в Волго-Уральском регионе. - Изучение и охрана большого и малого подорликов в Северной Евразии: Материамы к V международной конференции по хишным птицам Северной Евразии, Иваново, 4-7 февраля 2008 г. / РеА. В.Н. Мельников, В.Ч. Аомбровский, А.А. Мишенко. Иваново: Ивановский государственный университет, 2008с. C. 119-137. [Karyakin I.V. Ecology of the Greater Spotted Eagle in Volga-Ural Region. - Research and Conservation of the Greater Spotted Eagle and Lesser Spotted Eagle in Northern Eurasia: Proceedings of the V International Conference on Raptors of Northern Eurasia, Ivanovo, 4-7 February 2008 г. / Eds. V.N. Melnikov, V.Ch. Dombrovskiy, A.L. Mischenko. Ivanovo, 2008c: 119-137 (in Russian).]. URL: http://rrrcn.ru/ ru/archives/11198 Аата обрашения: 12.12.2017.

Карякин И.В. Особенности экологии большого подорлика в Запанной Сибири. - Изучение и охрана большого и малого подорликов в Северной Евразии: Материалы к V международной конференции по хищным птицам Северной Евразии, Иваново, 4-7 февраля 2008 г. / Ред. В.Н. Мельников, В.Ч. Аомбровский, А.А. Мишенко. Иваново: Ивановский государственный университет, 2008d. С. 153-164. [Karyakin I.V. Ecology of the Greater Spotted Eagle in Western Siberia. - Research and Conservation of the Greater Spotted Eagle and Lesser Spotted Eagle in Northern Eurasia: Proceed- ings of the V International Conference on Raptors of Northern Eurasia, Ivanovo, 4-7 February 2008 r. / Eds. V.N. Melnikov, V.Ch. Dombrovskiy, A.L. Mischenko. Ivanovo, 2008d: 153164 (in Russian).]. URL: http://rrrcn.ru/ru/archives/11198 Аата обрашения: 12.12.2017.

Карякин И.В. О возможностях ГИС в оценке численности и прогнозировании размешения гнездяшихся хищных птиц: апробация методик на примере анамиза пространственного распределения могильника и беркута в Волго-Уральском регионе, Россия. - Пернатые хишники и их охрана. 2010. № 19. C. 97-135. [Karyakin I.V. Using GIS-Software for Estimation of Number and Forecasting the Distribution of Breeding Raptors: Approbation of Methods for Examples of Analysis of Distribution of the Imperial Eagle and Golden Eagle in the Volga-Ural Region, Russia. - Raptors Conservation. 2010. 19: 97-135.]. URL: http://rrrcn.ru/ru/archives/19332 Аата обрашения: 12.12.2017.

Карякин И.В. Бамобан (Falco cherrug). - Российская сеть изучения и охраны пернатых хишников. 2012. [Karyakin I.V. Saker Falcon (Falco cherrug). - Russian Raptor Research and Conservation Network. 2012.] URL: http:// rrrcn.ru/keyspecies/f_cher/o-balobane $\Delta$ ата обрашения: 12.12.2017.

Карякин И.В. Результаты мониторинга популяции срилина в менточных борах Алтайского края, Россия. - Пернатые хишники и их охрана. 2014. № 29. С. 77-92. [Karyakin I.V. Monitoring Results of the Eagle Owl Population in the Strip-shaped Pine Forests in the Altai Kray, Russia. - Raptors Conservation. 2014. 29: 77-92.] DOI: 10.19074/1814-86542014-29-77-92 URL: http://rrrcn.ru/ru/archives/25722 $\triangle$ ата обрашения: 12.12.2017.

Карякин И.В. Алтайлес продолжает уничтожать местообитания редких видов хишных птиц в боровых заказниках Алтайского края. - Российская сеть изучения и охраны пернатых хищников. 2015 [Karyakin I.V. Altayles continues to destroy habitats of rare species of raptors in the Wildlife Nature Reserves of the Altai Kray. - Russian Raptor Research and Conservation Network. 2015. (in Russian)]. URL: http://rrrcn. ru/ru/archives/24033 Аата обрашения: 12.12.2017.

Карякин И.В., Бакка С.В., Грабовский М.А., Коновачов А.И., Мошкин А.В., Паженков А.С. Смелянский И.Э., Рыбенко А.В. Бамобан (Falco cherrug) в России. - Инвентаризация, мониторинг и охрана киючевых орнитологических территорий России. Вып. 5. / Отв. реА. С.А.Букреев. М.: Союз охраны птиц России, 2005a. С. 48-66. [Karyakin I.V., Bakka S.V., Grabovskiy M.A., Konovalov L.I., Moshkin A.V., Pazhenkov A.S., Smelyanskiy I.E., Rybenko A.V. Saker Falcon (Falco cherrug) in Russia. - Cadastre, monitoring and protection of IBAs Russia. Vol. 5. / S.A. Bukreev (Ed.). Moscow, 2005a: 48-66 (in Russian).]. URL: http://rrrcn.ru/wp-content/uploads/2012/11/Karyakin_2005.pdf Аата обрашения: 12.12.2017.

Карякин И.В., Барабашин Т.О., Аевин А.С., Карпов Ф.Ф. Результаты исследований 2005 г. в степных борах на северо-востоке Казахстана. - Пернатые хишники и их охрана. 2005b. № 4. C. 34-43. [Karyakin I.V., Levin A.S., Barabashin T.O., Karpov F.F. Results of Researches of Steppe Pine Forests in the Northeast of Kazakhstan in 2005. - Raptors Conservation. 2005b. 4: 34-43.]. URL: http://docs.sibecocenter.ru/ programs/raptors/RC04/raptors_conservation_2005_4_pages_34_43.pdf Аата обрашения: 12.12.2017.

Карякин И., Вагин А., Штоль $\Delta$. Результаты исследований хищных птиц в алтайских ленточных борах в 2014 г. - Российская сеть изучения и охраны пернатых хищников. 2015a [Karyakin I., Vagin A., Shtol D. The results of studies 
of raptors in the Altai pine-forests in 2014. - Russian Raptor Research and Conservation Network. 2015a (in Russian).]. URL: http://rrrcn.ru/ru/archives/22682 Аата обрашения: 12.12.2017

Карякин И.В., Коваленко А.В., Аевин А.С., Паженков А.С. Орлы Арало-Каспийского региона, Казахстан. - Пернатые хишники и их охрана. 2011. № 22. С. 92-152. [Karyakin I.V., Kovalenko A.V., Levin A.S., Pazhenkov A.S. Eagles of the Aral-Caspian Region, Kazakhstan. - Raptors Conservation. 2011. 22: 92-152.]. URL: http://rrrcn.ru/ru/archives/12738 Аата обрашения: 12.12.2017.

Карякин И.В., Корепов М.В. Гнездование могимьника на опоре ЛЭП в Кустанайской области, Казахстан. - Пернатые хишники и их охрана. 2009. № 13 C. 89 [Karyakin I.V., Korepov M.V. Imperial Eagle Breeding on the Electric Pole in Kostanay District, Kazakhstan. - Raptors Conservation. 2009. 13: 89]. URL: http://rrrcn.ru/ru/archives/24931 Аата обрашения: 12.12 .2017

Карякин И.В., Левашкин А.П., Паженков А.С., Коржев $\Delta . A$. Результаты привлечения неясытей в искусственные гнёзда в Самарской области, Россия. - Пернатые хишники и их охрана. 2009а. № 16. С. 25-41. [Karyakin I.V., Levashkin A.P., Pazhenkov A.S., Korzhev D.A. Results of the Ural Owl and Tawny Owl Attracting into Nestboxes in the Samara District, Russia. - Raptors Conservation. 2009a. 16: 25-41.]. URL: http://rrrcn.ru/ru/archives/19492 Аата обрашения: 12.12.2017.

Карякин И.В., Аевин А.С., Мошкин А.В., Николенко Э.Г. Балобан в России и Казахстане. - XIV Международная орнитологическая консеренция Северной Евразии. II. Аокиады. Алматы, 2015b. C. 473-530. [Karyakin I.V., Levin A.S., Moshkin A.V., Nikolenko E.G. Saker Falcon in Russia and Kazakhstan. - XIV International Ornithological Conference of Northern Eurasia. II. Oral presentations. Almaty, 2015b: 473-530.] URL: http://rrrcn.ru/ru/archives/25433 Аата обрашения: 12.12.2017.

Карякин И.В., Николенко Э.Г. Аербник в Алтае-Саянском регионе, Россия. - Пернатые хишники и их охрана. 2009. № 17. C. 98-120. [Karyakin I.V., Nikolenko E.G. Merlin in the Altai-Sayan Region, Russia. - Raptors Conservation. 2009 18: 98-120.]. URL: http://rrrcn.ru/ru/archives/19451 Аата обрашения: 12.12 .2017$.

Карякин И.В., Николенко Э.Г. Результаты проекта по выАелению зон особой охраны в трёх боровых заказниках Аитайского края на основании данных мониторинга мест гнездования пернатых хишников, Россия. - Пернатые хишники и их охрана. 2015a. № 31. C. 75-102. [Karyakin I.V., Nikolenko E.G. The Results of the Project on Creation of Special Protection Zones in Pine Forests of the Altai Kray Based on Data from the Long-term Monitoring of Raptors' Nesting Sites, Russia. - Raptors Conservation. 2015a. 31: 75-102.] DOI: 10.19074/1814-8654-2015-31-75-102 URL: http:// rrrcn.ru/ru/archives/26098 Аата обрашения: 12.12.2017.

Карякин И.В., Николенко Э.Г. Первые регистрации сиучаев размножения большого подорлика в гнездовых постройках беркута и орлана-белохвоста в Алтайском крае, Россия. - Пернатые хищники и их охрана. 2015b. № 31 C. 156-160. [Karyakin I.V., Nikolenko E.G. The First Record of Cases of Breeding the Greater Spotted Eagle in Old Nests of the Golden Eagle and White-Tailed Eagle in the Altai Kray, Russia. - Raptors Conservation. 2015b. 31: 156-160.] DOI: 10.19074/1814-8654-2015-31-156-160 URL: http://rrrcn. ru/ru/archives/26114 Аата обрашения: 12.12.2017.

Карякин И., Николенко Э. Обследован Алеусский заказник. - Российская сеть изучения и охраны пернатых хищ- ников. 2016. [Karyakin I., Nikolenko E. The Aleus Nature Reserve was observed. - Russian Raptor Research and Conservation Network. 2016 (in Russian).]. URL: http://rrrcn.ru/ ru/archives/26697 Аата обрашения: 12.12.2017.

Карякин И.В., Николенко Э.Г., Проммер М., Кази Р. Первый случай гнездования скопы на опоре высоковольтной АЭП в Саяне, Россия. - Пернатые хищники и их охрана. 2017. № 34. C. 100-104. [Karyakin I.V., Nikolenko E.G., Prommer M., Kazi R. The First Record of Nesting of the Osprey on the Highvoltage Power Pole in the Sayan Mountains, Russia. - Raptors Conservation. 2017. 34: 100-104.] DOI: 10.19074/1814-8654-2017-34-100-104 URL: http://rrrcn. ru/ru/archives/28707 Аата обрашения: 12.12.2017.

Карякин И.В., Паженков А.С. Могильник в Самарской области, Россия. - Пернатые хишники и их охрана. 2010. № 20. C. 97-118 [Karyakin I.V., Pazhenkov A.S. The Imperial Eagle in the Samara District, Russia. - Raptors Conservation. 2010. 20: 97-118.]. URL: http://rrrcn.ru/ru/archives/19250 Аата обрашения: 12.12.2017.

Карякин И.В., Паженков А.С., Коржев А.А. Орлан-белохвост в Самарской области, Россия. - Пернатые хишники и их охрана. 2009b. № 13 C. 31-40. [Karyakin I.V., Pazhenkov A.S., Korzhev D.A. The White-Tailed Eagle in the Samara District, Russia. - Raptors Conservation. 2009b. 13: 31-40.]. URL: http://rrrcn.ru/ru/archives/24908 Аата обрашения: 12.12.2017

Карякин И.В., Паженков А.С., Мошкин А.В., Барабашин T.О., Корольков М.А., Бекмансуров Р.Х. Могильник в Ураиьском регионе, Россия. - Пернатые хишники и их охрана. 2010. № 20. C. 128-145. [Karyakin I.V., Pazhenkov A.S., Moshkin A.V., Barabashin T.O., Korolkov M.A., Bekmansurov R.H. The Imperial Eagle in the Ural Region, Russia. - Raptors Conservation. 2010. 20: 128-145.]. URL: http://rrrcn.ru/ru/ archives/19260 Аата обрашения: 12.12.2017.

Карякин И.В., Смелянский И.Э., Бакка С.В., Грабовский М.А., Рыбенко А.В., Егорова А.В. Крупные пернатые хишники Аитайского края. - Пернатые хищники и их охрана, 2005с. № 3. C. 28-51. [Karyakin I.V., Smelansky I.E., Bakka S.V., Grabovsky M.A., Rybenko A.V., Egorova A.V. The Raptors in the Altai Kray. - Raptors Conservation. 2005c. 3: 28-51.]. URL: http:// docs.sibecocenter.ru/programs/raptors/RC03/raptors_conservation_2005_3_pages_28_51.pdf Аата обрашения: 12.12.2017.

Ковач, А., Уимиамс, Н.П., Гэлбрэйт, К.А. МежАународный План Аействий по балобану Falco cherrug (SakerGAP), вкиючая систему менеджмента и мониторинга мия сохранения вида. МоВ по Хищным Птицам Технический Аокумент Номер 2. КМВ Техническая Серия Номер 31. Координационный Центр - КМВ Хищные Птицы МоB, Абу-Ааби, Объединенные Арабские Эмираты, 2014. 160 с. [Kovacs A., Williams N.P., Galbraith C.A. Saker Falcon Falco cherrug Global Action Plan (SakerGAP), including a management and monitoring system, to conserve the species. Raptors MOU Technical Publication No. 2. CMS Technical Series No. 31. Coordinating Unit - CMS Raptors MOU, Abu Dhabi, United Arab Emirates, 2014: 1-206.] URL: http://www.cms.int/dugong/ sites/default/files/document/SakerGAP_r_0.pdf $\triangle$ ата обращения: 29.12.2017.

Кодекс Российской Федерации об амминистративных правонарушениях от 30.12.2001 № 195-Ф3 (реА. от 29.12.2017). Принят Государственной Аумой 20 декабря 2001 года. ОАобрен Советом Фелерации 26 декабря 2001 rosa. [The Code of the Russian Federation on Administrative Offenses of 30/12/2001 No. 195-FZ (as amended on December 29, 2017) (in Russian).]. URL: http://www.consult- 
ant.ru/document/cons_doc_LAW_34661 Аата обрашения: 29.12.2017.

Корепов М.В. Нетипичные сиучаи гнездования могильника на юге УАьяновской области, Россия. - Пернатые хишники и их охрана. 2009. № 16. C. 161-163 [Korepov M.V. Records of the Imperial Eagle Atypical Nesting in the South of the Ulyanovsk District, Russia. - Raptors Conservation. 2009. 16: 161-163]. URL: http://rrrcn.ru/ru/archives/19517 $\triangle$ ата обрашения: 12.12.2017.

Кучин А.П. Птицы Алтая. Горно-Алтайск, 2004. 777 с. [Kuchin A.P. Birds of Altai. Gorno-Altaisk, 2004: 1-777 (in Russian)].

Аевин А., Шмыгаиёв С., Аиксон А., Кунка Т. Бамобан в борах северо-восточного Казахстана. - Пернатые хишники и их охрана. 2007. № 8. С. 48-52. [Levin A., Shmigalev S., Dixon A., Kunka T. The Saker Falcon in pine forests of north-eastern Kazakhstan. - Raptors Conservation. 2007. 8: 48-52.]. URL: http://docs.sibecocenter.ru/programs/raptors/ RC08/raptors_conservation_2007_8_pages_48_52.pdf Аата обрашения: 12.12.2017.

Аенева Е.А., Аавыгора А.В. Сравнительная характеристи-

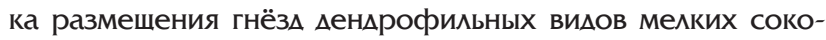
лов в степях Южного Урала. - Вестник ОГУ. 2006. № 5. C. 120-125. [Leneva E.A., Davygora A.V. Comparative feature of location of nests of dendrophilous species of small falcons in the steppes of the Southern Urals. - Vestnik OSU. 2006. 5: 120-125 (in Russian).]. URL: http://vestnik.osu. ru/2006_5_1/26.pdf Аата обрашения: 12.12.2017.

Аесохозяйственные регламенты лесничеств. - Министерство природных ресурсов и экологии Алтайского края (Минприроды Аитайского края). 2016. [Forest management regulations of forestries. - Ministry of Natural Resources and Ecology of the Altai Kray (Ministry of Natural Resources of the Altai Kray). 2016. (in Russian).]. URL: http://altaipriroda.ru/ dokument/inye_dokumenty/lesoxozjajstvennye_reglamenty_lesnichestv Аата обрашения: 29.12.2017.

Аоктев А.А., Аоктев $\Delta . A$. Метод определения расстояния Ао объекта путём анамиза размытия его изображения. Вестник МГСУ. 2015. № 6. С. 140-151. [Loktev A.A., Loktev $D$.A. Method of determining the distance to the object by analyzing its image blur. - Vestnik MGSU. 2015. 6: 140-151. (in Russian)] DOI: 10.22227/1997-0935.2015.6.140-151 URL: http://www.vestnikmgsu.ru/index.php/ru/archive/article/display/116/16 Аата обрашения: 29.12.2017.

Марковский А.В., Ильина О.В. Методические рекомендации по сохранению биологического разнообразия при лесосечных работах мия Республики Карелия. Петрозаводск: изд-во “Скандинавия", 2010. 50 с. [Markovsky A.V., Ilyina O.V. Methodical recommendations on conservation of biological diversity during the logging operations for the Republic of Karelia. Petrozavodsk, 2010: 1-50 (in Russian).]. URL: http://hcvf.ru/pub_doc/Metodicheskie_rekomendacii_po_ sohraneniju_biologicheskogo_raznoobrazija_dlja_Respubliki_ Karelija.pdf Аата обрашения: 29.12.2017.

Марковский А.В., Ильина О.В. Методические рекоменАации по сохранению биологического разнообразия при заготовке Аревесины в Вологодской области. М.: Всемирный фонд Аикой природы (WWF), 2014. 52 с. [Markovsky A.V., Ilyina O.V. Methodical recommendations on conservation of biological diversity during the forest harvesting in the Vologda region. Moscow, 2014: 1-52 (in Russian).]. URL: http://spok-karelia.ru/uploads/f111.pdf $\triangle$ Аата обрашения: 29.12.2017.

Мельников В.Н. Хишные птицы в городах Европейского центра России. - Животные в городе. Материалы научно- практической консеренции. М.: РСХА, 2003. С. 60-62. [Melnikov V.N. Birds of prey in the cities of the European center of Russia. - Animals in the city. Materials of the scientific-practical Conference. Moscow, 2003: 60-62 (in Russian).].

Митропольский О.В., Фоттелер Э.Р., Третьяков Г.П. Отрял соколообразные Falconiformes. - Птицы Узбекистана. T. 1. Ташкент, 1987. С. 123-247. [Mitropolsky O.V., Fotteler E.R., Tretyakov G.P. Birds of Prey Falconiformes. - Birds of Uzbekistan. Vol. 1. Tashkent, 1987: 123-247 (in Russian)]. URL: http://rrrcn.ru/ru/archives/11194 Аата обрашения: 12.12.2017.

Мишенко А.А. Большой подорлик Aquila clanga (Pallas, 1811). - Красная книга Российской Федерации (животные). M., 2001. C. 435-436. [Mischenko A.L. Greater Spotted Eagle Aquila clanga (Pallas, 1811). - Red Data Book of Russian Federation (animals). Moscow, 2001: 435-436 (in Russian).]. URL: http://biodat.ru/db/rb/rb.php?src=1\& vid=280 Аата обрашения: 12.12.2017.

Мороз В.А., Ветров В.В. О гнездовании орла-карлика в Ауганской области, Украина. - Пернатые хищники и их охрана. 2013. № 27. С. 197-207. [Moroz V.A., Vetrov V.V. About Breeding of the Booted Eagle in the Lugansk District, Ukraine. - Raptors Conservation. 2013. 27: 197-207]. URL: http://rrrcn.ru/ru/archives/21205 Аата обрашения: 12.12.2017.

Мороз В.А., Концратенко А.В. Ястреб-тетеревятник в окрестностях заповедника «Проваиьская степь" (Восточная Украина). - Ястреб-тетеревятник: место в экосистемах России. Материалы к IV конференции по хишным птицам Северной Евразии. Пенза, 1-3 февраяя 2003 г. / РеА. В.П. Белик. Пенза-Ростов, 2003. С. 91-93. [Moroz V.A., Kondratenko A.V. Goshawk in the vicinity of the State Nature Reserve "Provalskaya Steppe" (Eastern Ukraine). - Goshawk: Position in ecosystems of Russia. Materials of the $4^{\text {th }}$ NorthEurasian Conference on Raptors, Penza, Russia, 1-3 February 2003 / V.P. Belik (Ed.). Penza-Rostov, 2003: 91-93 (in Russian).]. URL: http://rrrcn.ru/ru/archives/22457 $\triangle$ ата обрашения: 12.12.2017.

Морозов В.В., Брагин Е.А., Ивановский В.В. Аербник / под реА. В.В. Морозова. Витебск: ВГУ имени П.М. Машерова, 2013. 256 с. [Morozov V.V., Bragin E.A., Ivanovski V.V. Merlin / Ed. V.V. Morozov. Vitebsk, 2013: 1-256. In Russian with English summary]. URL: http://rrrcn.ru/ru/archives/23129 Аата обрашения: 12.12.2017.

Москвичев А.Н., Бородин О.В., Корепов М.В., Корольков М.А. Птицы города УАьяновска: видовой состав, распространение, мимитируюшие сракторы и меры охраны. Ульяновск: «Корпорация технологий продвижения", 2011. 280 c. [Moskvichev A.N., Borodin O.V., Korepov M.V., Korolkov M.A. Birds of the city of Ulyanovsk: species composition, distribution, limiting factors and measures of protection. Ulyanovsk, 2011 : 1-280 (in Russian).].

Николенко Э.Г. Изнанка "Стратегии развития лесной отрасии А^тайского края на период Ао 2025 года». - Пернатые хишники и их охрана. 2014. № 29. С. 10-17. [Nikolenko E.G. The Reverse Side of the "Strategy of the Altai Kray Forest Industry for the Period up to the Year 2025". - Raptors Conservation. 2014. 29: 10-17.] DOI: 10.19074/1814-86542014-29-10-17 URL: http://rrrcn.ru/ru/archives/25765 $\triangle$ ата обрашения: 12.12.2017.

Николенко Э.Г., Карякин И.В., Грибков А.В. Проблемы охраны месных местообитаний редких видов в регионаиьных заказниках Аитайского края постепенно решаются. - Пернатые хишники и их охрана. 2012. № 25. С. 28-33 [Niko- 
lenko E.G., Karyakin I.V., Gribkov A.V. Problems of Protection of Forest Habitats of Rare Species in Regional Reserves of the Altai Kray are Resolving. - Raptors Conservation. 2012. 25: 28-33]. URL: http://rrrcn.ru/archives/19090 Аата обрашения: 12.12 .2017$.

Николенко Э.Г., Карякин И.В., Грибков А.В. Проблемы охраны ^есных местообитаний реАких видов хищных птиц в регионаиьных заказниках Алтайского края. - Охрана птиц в России: проблемы и перспективы. Мат-лы Всероссийской научно-практической конференции с международным участием, посвяшенной 20-летию Союза охраны птиц России (Москва, 7-8 февраля 2013 г.) / Отв. РеА. Г.С. Ажамирзоев. Москва, Махачкала, 2013. С. 102-105. [Nikolenko E.G., Karyakin I.V., Gribkov A.V. Problems of Protection of Forest Habitats of Rare Species of Raptors in Regional Reserves of the Altai Kray are Resolving. - Problems and outlook of bird conservation in Russia. Proceedings of the All-Russian Conference, dedicated to the $20^{\text {th }}$ anniversary of Russian Bird Conservation Union (Moscow, 7-8 February 2013) / Ex. Editor G.S. Dzhamirzoev. Moscow - Makhachkala, 2013: 102-105 (in Russian).]. URL: http://rrrcn.ru/ru/archives/19662 Аата обрашения: 12.12 .2017$.

Паженков А.С., Карякин И.В., Левашкин А.П. Совы Самарской области, Россия. - Пернатые хишники и их охрана. 2009. № 17. C. 24-52. [Pazhenkov A.S., Karyakin I.V., Levashkin A.P. Owls in the Samara District, Russia. - Raptors Conservation. 2009. 17: 24-52.]. URL: http://rrrcn.ru/ru/archives/19435 Аата обрашения: 12.12.2017.

Пернатые хищники Мира (Веб-ГИС "Фаунистика»). 2017. [Raptors of the World (Web-GIS “Faunistics”). 2017.]. URL: http://raptors.wildlifemonitoring.ru Аата обрашения: 10.12.2017.

Пестов М.В. Гнездование орлана-белохвоста на опоре высоковольтной АЭП в Астраханской области, Россия. Пернатые хищники и их охрана, 2005. № 3. С. 65-66. [Pestov M.V. Nesting of the White-Tailed Eagle on powerlines in the Astrahan district, Russia. - Raptors Conservation. 2005. 3: 65-66]. URL: http://docs.sibecocenter.ru/programs/raptors/RC03/raptors_conservation_2005_3_pages_65_68.pdf Аата обрашения: 10.12.2017.

Пилипенко $\triangle . B$. О тетеревятнике в искусственных лесах юга Аонецкой области. - Ястреб-тетеревятник: место в экосистемах России. Материалы к IV конференции по хишным птицам Северной Евразии. Пенза, 1-3 февраля 2003 г. / РеА. В.П. Белик. Пенза-Ростов, 2003. С. 105-107. [Pilipenko D.V. About Goshawk in artificial forests of the south part of the Donetsk region. - Goshawk: Position in ecosystems of Russia. Materials of the 4th North-Eurasian Conference on Raptors, Penza, Russia, 1-3 February 2003 / V.P. Belik (Ed.). Penza-Rostov, 2003: 105-107 (in Russian).]. URL: http:// rrrcn.ru/ru/archives/22457 Аата обрашения: 12.12.2017.

Пиотников В.Н. Скопа - Pandion haliaetus Linnaeus, 1758. Красная книга Алтайского края. Том 2. Редкие и находяшиеся под угрозой исчезновения виды животных. Барнаул, 2016a. C. 143-145. [Plotnikov V.N. Osprey - Pandion haliaetus Linnaeus, 1758. - Red Data Book of the Altai Kray. Vol. 2. Rare and endangered species of animals. Barnaul, 2016a: 143145. (in Russian).]. URL: http://altaipriroda.ru/krasnaja_kniga $\triangle$ ата обрашения: 10.12.2017.

Пиотников В.Н. ЗмееяА - Circaetus gallicus Gmelin, 1788. Красная книга Алтайского края. Том 2. Редкие и находяшиеся под угрозой исчезновения виды животных. Барнаул, 2016b. C. 152-153. [Plotnikov V.N. Short-toed Eagle - Circaetus gallicus Gmelin, 1788. - Red Data Book of the Altai Kray. Vol. 2. Rare and endangered species of animals. Bar- naul, 2016b: 152-153. (in Russian).]. URL: http://altaipriroda. ru/krasnaja_kniga Аата обрашения: 10.12.2017.

Плотников В.Н. Бамобан - Falco cherrug Gray, 1834. Красная книга Алтайского края. Том 2. Редкие и находяшиеся под угрозой исчезновения виды животных. Барнаул, 2016с. C. 173-175. [Plotnikov V.N. Saker Falcon - Falco cherrug Gray, 1834. - Red Data Book of the Altai Kray. Vol. 2. Rare and endangered species of animals. Barnaul, 2016c: 173-175. (in Russian).].URL: http://altaipriroda.ru/ krasnaja_kniga Аата обрашения: 10.12.2017.

Постановление Правительства РФ от 19 февраля 1996 г. № 158 "О Красной книге Российской Федерации" [Decree of the Government of the Russian Federation of February 19, 1996 No. 158 "On the Red Data Book of the Russian Federation" (in Russian).]. URL: http://www.consultant.ru/document/cons_doc_LAW_9319 Аата обрашения: 12.12.2017.

Приказ Госкомэкологии РФ от 03.10.1997 № 419-а «Об утверждении Порядка ведения Красной книги Российской Федерации" (Зарегистрировано в Минюсте РФ 24.12.1997 № 1435). [Order of the State Ecological Committee of the Russian Federation of 03.10.1997 No. 419-a "On approval of the Order on conduct of the Red Data Book of the Russian Federation" (Registered in the Ministry of Justice of the Russian Federation on 24.12.1997 No. 1435) (in Russian).]. URL: $\quad$ http://www.consultant.ru/document/cons_doc_ LAW_17364 Аата обрашения: 12.12.2017.

Приказ МПР РФ от 16.07.2007 N 184 «Об утверждении Правия заготовки Аревесины" (Зарегистрировано в Минюсте РФ 22.10.2007 N 10374) [Order of the Ministry of Natural Resources of the Russian Federation of 16/07/2007 N 184 "On approval of the rules for timber harvesting" (Registered in the Ministry of Justice of the Russian Federation on October 22, 2007 N 10374) (in Russian).]. URL: http://www.consultant.ru/document/cons_doc_LAW_72030 Аата обрашения: 12.12.2017.

Приказ Рослесхоза от 12.12.2011 г. № 516 «Об утвержАении Лесоустроительной инструкции" (Зарегистрировано в Минюсте РФ 06.03.2012 N 23413). [Order of the Federal Forestry Agency of December 12, 2011, No. 516 "On Approval of the Forest Inventory Regulations" (Registered in the Ministry of Justice of the Russian Federation on 06/03/2012 No. 23413) (in Russian).]. URL: http://www.consultant. ru/document/cons_doc_LAW_127082 Аата обрашения: 12.12.2017.

Пукинский Ю.Б. Аииннохвостая неясыть Strix uralensis (Pallas, 1771). - Птицы России и сопредельных регионов: Совообразные, Козодоеобразные, Стрижеобразные, Рак-


Н.И. Зубков, В.П. Иванчев и Ар. Москва: Товарищество научных изданий КМК, 2005а. С. 72-85. [Pukinskiy Yu.B. Ural Owl Strix uralensis (Pallas, 1771). - Birds of Russia and adjacent areas: Strigiformes, Caprimulgiformes, Apodiformes, Coraciiformes, Upupiformes, Piciformes / V.T. Butyev, N.I. Zubkov, V.P. Ivanchev et al. (Eds). Moskva, 2005a: 72-85 (in Russian).]. URL: http://www.egir.ru/bird/169. html Аата обрашения: 12.12.2017.

Пукинский Ю.Б. Бородатая неясыть Strix nebulosa (J. R. Forster, 1772). - Птицы России и сопредельных регионов: Совообразные, Козодоеобразные, Стрижеобразные, Ракшеобразные, УАодообразные, Аятлообразные / В.Т. Бутьев, Н.И. Зубков, В.П. Иванчев и др. Москва: Товаришество научных изАаний КМК, 2005b. C. 86-98. [Pukinskiy Yu.B. Great Grey Owl Strix nebulosa (J.R. Forster, 1772). - Birds of Russia and adjacent areas: Strigiformes, Caprimulgiformes, Apodiformes, Coraciiformes, Upupiformes, Piciformes / V.T. Butyev, 
N.I. Zubkov, V.P. Ivanchev et al. (Eds). Moskva, 2005b: 86-98 (in Russian).]. URL: http://www.egir.ru/bird/170.html $\triangle$ ата обрашения: 12.12.2017.

Пшегусов P.X. К экологии могильника Aquila heliaca (Falconiformes, Aves) на Центральном Кавказе. - Известия Самарского научного центра Российской акацемии наук. 2010. T. 12, № 1. C. 142-146 [Pshegusov R.K. On ecology of the Imperial Eagle Aquila heliaca (Falconiformes, Aves) in the Cenral Caucasus. - Proceedings of the Samara Scientific Center of the Russian Academy of Sciences. 2010. 12(1): 142-146 (in Russian).]. URL: http://www.ssc.smr.ru/media/ journals/izvestia/2010/2010_1_142_146.pdf Аата обрашения: 12.12.2017.

Рахимов И.И. (реА.) Птицы городов Среднего Поволжья и Предураиья. Казань: Мастер Аайн, 2001. 272 с. [Rakhimov I.I. (ed.) Birds of the cities of the Middle Volga and Pre-Ural region. Kazan, 2001: 1-272 (in Russian).].

Рединов К.А. Ястреб-тетеревятник в Николаевской области. - Ястреб-тетеревятник: место в экосистемах России. Материаиы к IV конференции по хишным птицам Северной Евразии. Пенза, 1-3 февраяя 2003 г. / Ред. В.П. Белик. Пенза-Ростов, 2003. С. 108-112. [Redinov K.A. Goshawk in the Mykolayiv region. - Goshawk: Position in ecosystems of Russia. Materials of the 4th North-Eurasian Conference on Raptors, Penza, Russia, 1-3 February 2003 / V.P. Belik (Ed.). Penza-Rostov, 2003: 108-112 (in Russian).]. URL: http:// rrrcn.ru/ru/archives/22457 Аата обрашения: 12.12.2017.

Рыжков А.В. Хохлатый осоеА - Pernis ptilorhynchus (Temminck, 1821). - Красная книга Алтайского края. Том 2. Редкие и находяшиеся под угрозой исчезновения виды животных. Барнаул, 2016. C. 145-146. [Ryzhkov D.V. Oriental Honey Buzzard Pernis ptilorhynchus (Temminck, 1821). Red Data Book of the Altai Kray. Vol. 2. Rare and endangered species of animals. Barnaul, 2016: 145-146. (in Russian).]. URL: http://altaipriroda.ru/krasnaja_kniga Аата обрашения: 12.12.2017

Рыкова С.Ю. Беркут Aquila chrysaetos (Linnaeus, 1758), Орлан-белохвост Haliaeetus albicilla (Linnaeus, 1758). Красная книга Архангельской области (официамьное издании). Архангельск, 2008. С. 274-277. [Rykova S. Yu. Golden Eagle Aquila chrysaetos (Linnaeus, 1758), White-Tailed Eagle Haliaeetus albicilla (Linnaeus, 1758). - Red Data Book of the Arkhangelsk Region (Official edition). Arkhangelsk, 2008: 274-277 (in Russian).].

Самойлов Б.А., Морозова Г.В. Перепелятник Accipiter nisus (Linnaeus, 1758). - Красная книга города Москвы. 2-е изА. М., 2011. С. 134-136. [Samoylov B.L., Morozova G.V. Sparrowhawk Accipiter nisus (Linnaeus, 1758). - Red Data Book of Moscow. Second edition. Moscow, 2011: 134-136 (in Russian).]. URL: http://oopt.aari.ru/ref/309 Аата обрашения: 31.12.2017.

Соколов А.Ю. О некоторых примерах толерантности орлана-белохвоста по отношению к человеку в условиях южной части Центраиьного Черноземья. - Пернатые хищники и их охрана. 2013. № 27. С. 215-220. [Sokolov A.Yu. On Some Examples of the Tolerance of White-Tailed Eagle in Relation to Man in the Southern Part of the Central Chernozem Region. - Raptors Conservation. 2013. 27: 215-220.]. URL: http://rrrcn.ru/ru/archives/21216 Аата обрашения: 31.12.2017.

Федеральный закон от 10.01.2002 № 7-Ф3 (ред. от 31.12.2017) «Об охране окружающей среды». Принят Государственной Аумой 20 декабря 2001 года. ОАобрен Советом Федерации 26 цекабря 2001 года. [Federal Law No. 7-FZ of January 10, 2002 (as amended on December 31, 2017)
"On Environmental Protection" (in Russian)]. URL: http:// www.consultant.ru/document/cons_doc_LAW_34823 Аата обрашения: 31.12.2017.

Федерамьный закон от 24.04.1995 N 52-Ф3 (ред. от 03.07.2016) "О животном мире». Принят Государственной Аумой 22 марта 1995 года. [Federal Law No. 52-FZ of April 24, 1995 (as amended on July 3, 2016) "On the Animals" (in Russian).]. URL: http://www.consultant.ru/document/cons_ doc_LAW_6542 Аата обрашения: 12.12.2017.

Храбрый В.М. (ред.) Птицы городов России. СПб., М.: Товаришество научных изданий КМК, 2012. 513 с. [Khrabryi V.M. (ed.) Birds of the cities of Russia. St. Petersburg, Moscow, 2012: 1-513 (in Russian).].

Abuladze A., Shergalin E. The Golden Eagle in North Caucasia and Transcaucasia. - Journal of Raptor Research. 2002. 36 (1 Supplement): 10-17. URL: https://sora.unm.edu/sites/ default/files/journals/jrr/v036n01s/p00010-p00017.pdf $\triangle$ ата обрашения: 12.12.2017.

Andrew J.M., Mosher J.A. Bald eagle nest site selection and nesting habitat in Maryland. - The Journal of Wildlife Management. 1982. 46: 383-390. DOI: 10.2307/3808650 URL: http://www.jstor.org/stable/3808650 Аата обращения: 12.12.2017.

Alterman L.E., Bednarz J.C., Thill R.E. Use of group-selection and seed-tree cuts by three early-successional migratory species in Arkansas. - The Wilson Bulletin. 2005. 117: 353-363. DOI: 10.1676/04-113.1 URL: http://www. bioone.org/doi/full/10.1676/04-113.1 Аата обрашения: 12.12.2017.

Amcoff M., Tjernberg M., Berg A. Bivrakens Pernis apivorus boplatsval [Nest site choice of Honey Buzzard Pernis apivorus]. - Ornis Svecica. 1994. 4(4): 145-158 (in Swedish). URL: https://www.researchgate.net/publication/259298912 Nest_site_choice_of_Honey_Buzzard_Pernis_apivorus $\triangle$ ата обрашения: 12.12.2017.

Anthony R., Isaacs F. Characteristics of Bald Eagle nest sites in Oregon. - The Journal of Wildlife Management. 1989. 53(1): 148-159. DOI: 10.2307/3801322 URL: http://www. jstor.org/stable/3801322 Аата обрашения: 12.12.2017.

Anthony R.G., Steidl R.J., McGarigal K. Recreation and bald eagles in the Pacific Northwest. - Wildlife and Recreationists: Coexistence Through Management and Research / Knight, R.L., Gutzwiller, K.J. (Eds.). Washington: Island Press, 1995: 223-241.

Babbington J., Campbell O. Recent status and occurrence of Crested Honey Buzzards Pernis ptilorhynchus in the Arabian peninsula, with emphasis on Saudi Arabia and the United Arab Emirates. - Sandgrouse. 2016. 38: 12-22. URL: https:// www.researchgate.net/publication/320237313_Recent_status_and_occurrence_of_Crested_Honey_Buzzards_Pernis_ ptilorhynchus_in_the_Arabian_peninsula_with_emphasis_on_Saudi_Arabia_and_the_United_Arab_Emirates $\triangle$ ата обрашения: 12.12.2017.

Bashta A.T. Ural Owl Strix uralensis Population Dynamics and Range Expansion in Western Ukraine. - Ardea. 2009. 97: 483-487. DOI: 10.5253/078.097.0412 URL: http:// www.bioone.org/doi/abs/10.5253/078.097.0412 Аата обрашения: 12.12.2017.

Beale C.M., Monaghan P. Behavioural responses to human disturbance: a matter of choice. - Animal Behaviour. 2004. 68: 1065-1069. DOI: 10.1016/j.anbehav.2004.07.002. URL: https://www.sciencedirect.com/science/article/pii/ S0003347204002660 Аата обрашения: 12.12.2017.

Becker D.M. Reproductive ecology and habitat utilisation of Richardson's merlins in southeastern Montana. Master of 
Science Thesis. University of Montana, Bozeman, Montana, 1984: 1-86.

Becker D.M., Ball I.J. Merlin (Falco columbarius). - Impacts of coal surface mining on 25 migratory bird species of high federal interest / J.S. Armbruster (Ed.). U.S. Fish and Wildlife Service FWS/OBS-83/35. 1983: 124-137. URL: http://www. dtic.mil/cgi-bin/GetTRDoc?AD=ADA322785\&Location=U2 \& doc=GetTRDoc.pdf $\triangle$ ата обрашения: 12.12.2017.

Bekmansurov R.H., Karyakin I.V., Pazhenkov A.S., Isakov G.N., Shnayder E.P. Establishing of new breeding groups of the White-Tailed Eagle Haliaeetus albicilla after constructing of water reservoirs in Volgo-kamskiy Region of Russia. - The collection of Abstracts and Short Notes of the SEAEAGLE 2017 conference: 5-7 October Roosta, Estonia: Eagle Club Estonia, 2017: 17-18. URL: http://www.kotkas.ee/seaeagle2017/files/WTSE2017_abstracts-and-short-notes.pdf $\triangle$ ата обрашения: 12.12.2017.

Bergo G. Habitat and nest site features of Golden Eagle Aquila chrysaetos (L.) in Hordaland, west Norway. - Fauna Norvegica Series C, Cinclus. 1984. 7: 109-113.

Bezzel E., Rust R., Kechele W. Territory turnover, reporduction and human persecution in a population of Goshawk Accipiter gentilis. - Journal fbr Ornithologie. 1997. 138 (4): 413-441. URL: https://link.springer.com/article/10.1007/ BF01651378 Аата обрашения: 12.12.2017.

Bierregaard R.O., Poole A.F., Martell M.S., Pyle P., Patten M.A. Osprey (Pandion haliaetus), version 2.0. - The Birds of North America / P.G. Rodewald Ed. Cornell Lab of Ornithology, Ithaca, New York, USA, 2016. DOI: 10.2173/bna.683 URL: https://birdsna.org/Species-Account/bna/species/683/articles/introduction Аата обрашения: 12.12.2017.

Bijleveld M. Birds of Prey in Europe. London, 1974: 1-288.

Bijlsma R.G. Stelselmatige vernietiging van bezette roofvogelnesten door Staatsbosbeheer [Systematic destruction of occupied raptor nests by forestry companies]. - De Takkeling. 1999. 7: 59-64. URL: http://natuurtijdschriften.nl/do wnload? type $=$ document\& docid $=546713$ Аата обрашения: 12.12.2017.

Bijlsma R.G. What is the predation risk for European Honeybuzzards Pernis apivorus in Dutch forests inhabited by foodstressed Northern Goshawks Accipiter gentilis? - Takkeling. 2004. 12(3): 185-197 (in Dutch). URL: http://natuurtijdschriften.nl/download? type $=$ document $\&$ docid $=546984$ Аата обрашения: 12.12.2017.

Bijlsma R.G. Raptors attacking people. - De Takkeling. 2008. 16(3): 208-218. URL: http://natuurtijdschriften.nl/do wnload? type $=$ document $\&$ docid $=547143$ Аата обрашения: 12.12.2017.

Bijlsma R., van Manen W. Local density, behaviour, food and moult of the Fox Kestrel Falco alopex. - Malimbus. 2017. 39: 44-55. URL: http://www.altwym.nl/uploads/ file/591_1513330292.pdf Аата обрашения: 12.12.2017.

BirdLife International. European Red List of Birds. Luxemburg: Office for Official Publications of the European Communities, 2015: 1-69. DOI: 10.2779/975810 URL: http:// ec.europa.eu/environment/nature/conservation/species/ redlist/downloads/European_birds.pdf $\Delta$ ата обрашения: 12.12.2017.

BirdLife International. Pernis apivorus. - The IUCN Red List of Threatened Species 2016: e.T22694989A93482980. 2016a. $\quad$ DOI: $10.2305 /$ IUCN.UK.2016-3.RLTS. T22694989A93482980.en URL: http://www.iucnredlist.org/ details/22694989/0 Аата обращения: 12.12.2017.

BirdLife International. Pernis ptilorhynchus. - The IUCN Red List of Threatened Species 2016: e.T22694995A93483912. 2016b. DOI: $\quad 10.2305 /$ IUCN.UK.2016-3.RLTS. T22694995A93483912.en URL: http://www.iucnredlist.org/ details/22694995/0 Аата обрашения: 12.12.2017.

BirdLife International. Clanga clanga (amended version of 2016 assessment). - The IUCN Red List of Threatened Species 2017: e.T22696027A110443604. 2017a. DOI: 10.2305/IUCN.UK.2017-1.RLTS.T22696027A1 10443604.en URL: http://www.iucnredlist.org/details/22696027/0 Аата обрашения: 12.12.2017.

BirdLife International. Aquila heliaca (amended version of 2016 assessment). - The IUCN Red List of Threatened Species 2017: e.T22696048A117070289. 2017b. DOI: 10.2305/IUCN.UK.2017-3.RLTS.T22696048A117070289.en URL: http://www.iucnredlist.org/details/22696048/0 Аата обрашения: 12.12.2017.

BirdLife International. Buteo buteo (amended version of 2016 assessment). - The IUCN Red List of Threatened Species 2017: e.T61695117A119279994. 2017c. DOI: 10.2305/ IUCN.UK.2017-3.RLTS.T61695117A119279994.en URL: http://www.iucnredlist.org/details/full/61695117/0 Дата обрашения: 12.12.2017.

BirdLife International. Bubo bubo (amended version of 2016 assessment). - The IUCN Red List of Threatened Species 2017: e.T22688927A113569670. 2017d. DOI: 10.2305/ IUCN.UK.2017-1.RLTS.T22688927A113569670.en URL: http://www.iucnredlist.org/details/full/22688927/0 Аата обрашения: 12.12.2017.

Björklund H., Valkama J., Tomppo E., Laaksonen T. Habitat Effects on the Breeding Performance of Three ForestDwelling Hawks. - PLoS One. 2015. 10(9): e0137877. DOI: 10.1371/journal.pone.0137877 URL: https://www.ncbi. nlm.nih.gov/pmc/articles/PMC4589344 Аата обрашения: 12.12.2017.

Blanco G. Role of refuse as food for migrant, floater and breeding Black Kite (Milvus migrans). - Journal of Raptor Research. 1997. 31(1): 71-76. URL: https://sora.unm.edu/ sites/default/files/journals/jrr/v031 n01/p00071-p00076.pdf $\triangle$ ата обрашения: 12.12.2017.

Blumstein D.T. Developing an evolutionary ecology of fear: how life history and natural history traits affect disturbance tolerance in birds. - Animal Behaviour. 2006. 71: 389-399. DOI: 10.1016/j.anbehav.2005.05.010 URL: https://pdfs. semanticscholar.org/2b9c/f431 ec4e6b0e465e7ad3de529c51c90650df.pdf Аата обрашения: 12.12.2017.

Bosch J., Borras A., Freixas J. Nesting habitat selection of booted eagle Hieraaetus pennatus in Central Catalonia. - Ardeola. 2005. 52(2): 225-233. URL: https://pdfs.semanticscholar.org/d9bc/41 e400b1 14d11a67a0ccd21588c537d75 9f3.pdf Аата обрашения: 12.12.2017.

Bouchart M.L. Great Gray Owl habitat use in southeastern Manitoba and the effects of forest resource management. Master of Science thesis, Univ. Manitoba, Winnipeg, Canada, 1991: 1-92. URL: https://mspace.lib.umanitoba.ca/handle/1993/22915 Аата обрашения: 12.12.2017.

Bowerman W.W., Grubb T.G., Bath A.J.; Giesy J.P., Weseloh D.V.C. A survey of potential bald eagle nesting habitat along the Great Lakes shoreline. Res. Pap. RMRS-RP-56WWW. Fort Collins, CO: U.S. Department of Agriculture, Forest Service, Rocky Mountain Research Station. 2005: 1-6. URL: https:// www.fs.fed.us/rm/pubs/rmrs_rp056 Аата обрашения: 12.12.2017.

Bragin E.A. Recent status and studies of the Saker Falcon in the Northern Kazakhstan. - Proceedings of the II International Conference on the Saker Falcon and Houbara Bustard, Mongolia, 1-4 July 2000. Ulaanbaatar, 2001: 110-115. URL: 
http://www.falcons.co.uk/mefrg/PDF/bragin-status.pdf $\Delta$ aтa обрашения: 12.12.2017.

Brazil M. Birds of East Asia: eastern China, Taiwan, Korea, Japan, eastern Russia. Christopher Helm, London, 2009: 1-528.

Britten M. Human impacts on golden eagles in northeastern Arizona. - Crossing Boundaries in Park Management: Proceedings of the 11 th Conference on Research and Resource Management in Parks and on Public Lands / D. Harmon ed. Michigan: the George Wright Society. 2001: 78-81. URL: http://www.georgewright.org/14britte.pdf $\triangle$ ата обрашения: 12.12.2017.

Bryan T., Forsman E. Distribution, abundance, and habitat of Great Gray Owls in southcentral Oregon. - The Murrelet. 1987. 68(2): 45-49.

Buehler D.A., Mersmann T.J., Fraser J.D., Seegar J.K.D. Effects of human activity and shoreline development on Bald Eagle distribution and abundance on the northern Chesapeake Bay. - The Journal of Wildlife Management. 1991. 55(2): 282-289. DOI: 10.2307/3809151 URL: http://www. jstor.org/stable/3809151 Аата обрашения: 12.12.2017.

Bull E.L., Henjum M.G. Ecology of the great gray owl. Gen. Tech. Rep. PNW-GTR-265. Portland, OR: U.S. Department of Agriculture, Forest Service, Pacific Northwest Research Station, 1990: 1-39. URL: https://www.fs.fed.us/pnw/pubs/ pnw_gtr265.pdf Аата обрашения: 12.12.2017.

Call M. Habitat management guides for birds of prey. U. S. Dep.Inter., Bur. Land Manage.Tech. Note338. 1979: 1-70.URL: https://archive.org/stream/habitatmanagemen00call\#page/ n0/mode/2up Аата обрашения: 12.12.2017.

Carlon J. Response of Booted Eagles to human disturbance. British Birds. 1996. 89: 267-274. URL: https://britishbirds. co.uk/wp-content/uploads/article_files/V89/V89_N06/V89_ N06_P267_274_A060.pdf Аата обрашения: 12.12.2017.

Cline K.W. Raptor nest and roost site management in the Southeast. - Proceedings of the Southeast Raptor Management Symposium and Workshop. National Wildlife Federation Science and Technical Series Number 14 / B.G. Pendleton, M.B. Moss, M.N. LeFranc Jr., B.A. Millsap (Eds). Washington, DC, 1990: 175-188.

Corr P.O. Bald Eagle (Haliaeetus leucocephalus alascanus) nesting related to forestry in southeastern Alaska. M. S. Thesis, Univ. Alaska, Fairbanks, 1974: 1-144. URL: https://scholarworks.alaska. edu/handle/11122/7420 Аата обрашения: 12.12.2017.

Crocker-Bedford D.C. Goshawk reproduction and forest management. - Wildlife Society Bulletin. 1990. 18(3): 262269. URL: https://www.fs.usda.gov/Internet/FSE_DOCUMENTS/fsbdev3_020868.pdf Аата обрашения: 12.12.2017.

Cunningham R. L. The status of the Bald Eagle in Florida. Audubon. 1960. 62(1): 24-26, 41, 43.

Currie F., Elliott G. Forests and Birds: A Guide to Managing Forests for Rare Birds. Forestry Authority, Cambridge and Royal Society for the Protection of Birds, Sandy, UK, 1997: 1-23. URL: http://ww2.rspb.org.uk/Images/forestsbirds_ tcm9-132888.pdf Аата обрашения: 12.12.2017.

Danko Š., Chavko J., Demeter G., Mihók J., Izakovič J., Latková H., Siryová S., Noga M., Nemček V. Conservation of Eastern Imperial Eagle in the Slovak part of the Carpathian basin - Results of the EU LIFE-Nature project (2003-2007). - Acta zoologica bulgarica, Suppl. 3. 2011: 71-78. URL: http://www.acta-zoologica-bulgarica.eu/downloads/actazoologica-bulgarica/2011/supplement-3-071-078.pdf $\Delta$ ата обрашения: 12.12.2017.

Demerdzhiev D., Gradev G.Zh., Stoychev S.A., Ivanov I.I., Petrov T.Hr., Marin S.A. Increase of the Population of the East- ern Imperial Eagle (Aquila heliaca) in Bulgaria. - Acta zoologica bulgarica, Suppl. 3. 2011 a: 41-54. URL: http://www. acta-zoologica-bulgarica.eu/downloads/acta-zoologica-bulgarica/2011/supplement-3-041-054.pdf Аата обрашения: 12.12.2017.

Demerdzhiev D., Horváth M., Kovács A., Stoychev S., Karyakin I. Status and Population Trend of the Eastern Imperial Eagle (Aquila heliaca) in Europe in the Period 2000-2010. - Acta zoologica bulgarica, Suppl. 3. 2011b: 5-14. URL: http://www.acta-zoologica-bulgarica.eu/downloads/actazoologica-bulgarica/2011/supplement-3-005-014.pdf $\triangle$ Ата обрашения: 12.12 .2017

D'Eon R.G., Watt W.R. Osprey management guidelines in northeastern Ontario: areview. OMNR, NEST Tech. Rpt. TR018. 1994.

Diaz M., Møller A.P., Flensted-Jensen E., Grim T., IbanezAlamo J.D., Jokimaki J., Marko G., Tryjanowski P. The Geography of Fear: A Latitudinal Gradient in Anti-Predator Escape Distances of Birds across Europe. - PLoS One. 2013. 8(5): e64634. DOI: 10.1371/journal.pone.0064634 URL: http://journals.plos.org/plosone/article?id=10.1371/journal. pone.0064634 Аата обрашения: 12.12.2017.

Dombrovski V.C. Greater Spotted Eagle population in Belarus: actual numbers, trends, habitats and occurrence of hybridization with Lesser Spotted Eagle. Presentation at the International Workshop on the conservation of the Greater Spotted Eagle conducted within LIFE08 NAT/PL/000511 AQC Plan "Securing the Population of Aquila clanga in Poland: Preparation of the National Action Plan and Primary Site Conservation”, Goniądz, Biebrza Valley, Poland, January, $25^{\text {th }}-27^{\text {th }}, 2012$. - Russian Raptor Research and Conservation Network. 2012. URL: http://rrrcn.ru/en/archives/10982 Аата обрашения: 12.12.2017.

Drachmann J., Nielsen J.T. Danske duehøges populationsøkologi og forvaltning. Danmarks Miljøundersøgelser. - Faglig rapport fra DMU, nr. 398. 2002. 53 s. [Drachmann J., Nielsen J.T. Population Ecology and Management of Danish Goshawk. Denmark's Environmental Research. - NERI Technical reports 398. 2002: 1-53 (in Danish).]. URL: http://www2. dmu.dk/1_viden/2_publikationer/3_fagrapporter/rapporter/ fr398.pdf Аата обрашения: 12.12.2017.

Dravecky M., Obuch J. Contribution to the knowledge on the synanthropization and dietary specialization of the Ural Owl (Strix uralensis) in urban environment of Košice city (East Slovakia). - Slovak Raptor Journal. 2012. 3: 51-60. DOI: $10.2478 / \mathrm{v} 10262-012-0033-3$ URL: https://www.degruyter.com/view/j/srj.2009.3.issue--1/v10262-012-00333/v10262-012-0033-3.xml Аата обрашения: 12.12.2017.

Duncan J.R. Great Gray Owls (Strix nebulosa nebulosa) and forest management in North America: a review and recommendations. - Journal of Raptor Research. 1997. 31(2): 160-166. URL: https://sora.unm.edu/sites/default/files/ journals/jrr/v031n02/p00160-p00166.pdf Аата обрашения: 12.12.2017.

Ellmauer T. (Hrsg.) Entwicklung von Kriterien, Indikatoren und Schwellenwerten zur Beurteilung des Erhaltungszustandes der Natura 2000-Schutzgüter. Band 1: Vogelarten des Anhangs I der Vogelschutz-Richtlinie. Im Auftrag der neun usterreichischen Bundesländer, des Bundesministerium $f$. Land- und Forstwirtschaft, Umwelt und Wasserwirtschaft und der Umweltbundesamt GmbH. Wien, 2005: 1-633. [Ellmauer $T$. (Ed.) Development of criteria, indicators and thresholds for assessing the conservation status of Natura 2000 protected assets. Volume 1: Bird species of Annex I to the Birds Directive. On behalf of the nine Austrian provinces, the Federal 
Ministry Agriculture and Forestry, Environment and Water Management and the Federal Environment Agency $\mathrm{GmbH}$. Wien, 2005: 1-633 (in German).]. URL: http://www.verwaltung.steiermark.at/cms/dokumente/11681048_123331241/ e8e290c8/Ellmauer.Band\%201_Vogelarten.pdf обрашения: 12.12.2017.

Ensign J.T. Nest site selection, productivity, and food habits of ferruginous hawks in southeastern Montana. Master of Science thesis, Montana State Univ., Bozeman. 1983: 1-85. URL: https://scholarworks.montana.edu/xmlui/bitstream/ handle/1/3891/31762001734522.pdf?sequence $=1 \quad$ Аата обрашения: 12.12 .2017 .

Ewins P.J. Osprey (Pandion haliaeetus) populations in forested areas of North America, changes, their causes and management recommendations. - Journal of Raptor Research. 1997. 31: 138-150. URL: https://sora.unm.edu/sites/ default/files/journals/jrr/v031n02/p00138-p00150.pdf $\triangle$ ата обрашения: 12.12.2017.

Ferguson-Lees J., Christie D.A. Raptors of the World. London: Christopher Helm, 2001: 1-992.

Fernández-Juricic E., Schroeder N. Do variations in scanning behaviour affect tolerance to human disturbance? - Applied Animal Behaviour Science. 2003. 84: 219-234. DOI: 10.1.1.590.1433. URL: http://citeseerx.ist.psu.edu/viewdoc/download?doi=10.1.1.590.1433\& rep=rep $1 \&$ type $=p d f$ Аата обрашения: 12.12.2017.

Fernández-Juricic E., Jimenez M.D., Lucas E. Alert distance as an alternative measure of bird tolerance to human disturbance: implications for park design. - Environmental Conservation. 2001. 28: 263-269. DOI: 10.1017/ S0376892901000273. URL: http://estebanfj.bio.purdue. edu/papers/EnvCons.pdf Аата обрашения: 12.12.2017.

Ferrer M., Garcia L., Cadenas R. Long-term changes in nest defence intensity of the Spanish imperial eagle Aquila adalberti. Ardea. 1990. 78. 395-398. URL: http://www.avibirds.

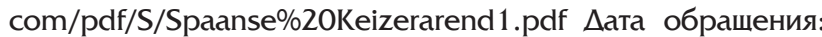
12.12.2017.

Finn S.P., Marzluff J.M., Varland D.E. Effects of landscape and local habitat attributes on northern goshawk site occupancy in western Washington. - Forest Science. 2002. 48(2): 427-436. URL: http://www.ingentaconnect.com/contentone/saf/fs/2002/00000048/00000002/art00026 Аата обрашения: 12.12 .2017 .

Fiuczynski K.D. The Eurasian Hobby (Falco subbuteo): Biology of an Aerial Hunter. Die Neue Brehm-Bıcherei: English Edition. Volume: 575. VerlagsKG Wolf, 2017: 1-394.

Forests and the forestry sector Russian Federation. - Food and Agriculture Organization of the United Nations. 2003. URL: http://www.fao.org/forestry/country/57478/en/rus Аата обрашения: 12.12.2017.

Forsman D., Ehrnsten B. Is the goshawk Accipiter gentilis declining? - Lintumies. 1985. 20: 83-88.

Fox A.D., Madsen J. Behavioural and distributional effects of hunting disturbance on waterbirds in Europe: implications for refuge design. - Journal of Applied Ecology. 1997. 34: 1-13. DOI: 10.2307/2404842 URL: http://www.shepway.gov.uk/ webapp/lydd-airport/CORE\%20DOCS/CD12/CD 12.27\%20 Applicant's\%20list\%20of\%20Ornithology/Fox\%20and\%20 Madsen.pdf Аата обрашения: 12.12.2017.

Fraser J.D., Anthony R.G. Human Disturbance and Bald Eagles. - Bald Eagles in Alaska / B.A. Wright and P.F. Schempf (Eds.). Juneau, Alaska, 2008: 306-314. URL: https://www. uas.alaska.edu/artssciences/docs/bald-eagles-ak12-07.pdf Аата обрашения: 12.12.2017.

Fraser J.D. The impact of human activities on bald eagle populations - a review. - The Bald Eagle in Canada / J.M. Gerrard and Ingram T.N., Eds. White Horse Plains Publishers, Headingley, Manitoba, 1983: 68-84.

Fraser J.D., Frenzel L.D., Mathisen J.E. The impact of human activities on breeding bald eagles in north-central Minnesota. - The Journal of Wildlife Management. 1985. 49: 585-592.

Galeotti P., Tavecchia G., Bonetti A. Parental defence in Long-eared Owls Asio otus: effects of breeding stage, parent sex and persecution. - Journal of Avian Biology. 2000. 31: 431-440. DOI: 10.1034/j.1600-048X.2000.310401.x URL: $\quad$ http://onlinelibrary.wiley.com/doi/10.1034/j.1600048X.2000.310401.x/abstract Аата обрашения: 12.12.2017.

Galushin V.M. A huge urban population of birds of prey in Delhi. - Ibis. 1971. 113(4): 522. DOI: 10.1111/j.1474919X.1971.tb05189.x URL: http://onlinelibrary.wiley. com/doi/10.1111/j.1474-919X.1971.tb05189.x/full Аата обрашения: 12.12 .2017$.

Gamauf A., Tebb G., Nemeth E. Honey Buzzard Pernis apivorus nest-site selection in relation to habitat and the distribution of Goshawks Accipiter gentilis. - Ibis. 2013. 155(2): 258-270. DOI: 10.1111/ibi.12023 URL: http://onlinelibrary. wiley.com/doi/10.1111/ibi.12023/abstract $\triangle$ ата обрашения: 12.12.2017.

Gendall J., Lill A., Beckman J. Tolerance of disturbance by humans in long-time resident and recent colonist urban doves. - Avian Research. 2015. 6: 7. DOI 10.1186/ s40657-015-0018-x URL: https://link.springer.com/content/ pdf/10.1186\%2Fs40657-015-0018-x.pdf Аата обрашения: 12.12.2017.

Gensbol B. Collins Guide to the Birds of Prey of Britain and Europe, North Africa and the Middle East. London, 1986: 1416.

Giacomo D.U., Guerrieri G. The Feeding Behavior of the Black Kite (Milvus migrans) in the Rubbish Dump of Rome. - J Raptor Res. 2008. 42(2): 110-118. DOI: 10.3356/JRR-0709.1 URL: http://www.bioone.org/doi/abs/10.3356/JRR-0709.1 Аата обрашения: 12.12.2017.

Gill J.A., Norris K., Sutherland W. Why behavioural responses may not reflect the population consequences of human disturbance. - Biological Conservation. 2001. 97: 265-268. DOI: $10.1016 /$ S0006-3207(00)00002-1 URL: http://citeseerx.ist.psu.edu/viewdoc/download?doi=10.1.1.546.453\& re p=rep 1 \& type=pdf $\triangle$ ата обрашения: 12.12.2017.

González L. M., Arroyo B. E., Margalida A., Sanchez R., Oria J. Effect of human activities on the behaviour of breeding Spanish imperial eagles (Aquila adalberti): management implications for the conservation of a threatened species. Animal Conservation. 2006. 9: 85-93. DOI: 10.1111/j.14691795.2005.00016.x URL: http://nora.nerc.ac.uk/id/ eprint/341 Аата обрашения: 12.12.2017.

Glover H.K., Weston M.A., Maguire G.S., Miller K.K., Christie B.A. Towards ecologically meaningful and socially acceptable buffers: response distances of shorebirds in Victoria, Australia, to human disturbance. - Landscape and Urban Planning. 2011. 103: 326-334. URL: http://www.birdlife.org. au/documents/BNB-Glover_et_al._unb.pdf $\triangle$ aта обрашения: 12.12.2017.

Gram W.K., Porneluzi P.A., Clawson R.L., Faaborg J., Richter S.C. Effects of experimental forest management on density and nesting success of bird species in Missouri Ozark forests. - Conservation Biology. 2003. 17: 1324-1337. DOI: 10.1046/j.1523-1739.2003.02171.x. URL: http://onlinelibrary.wiley.com/doi/10.1046/j.1523-1739.2003.02171.x/ full Аата обрашения: 12.12.2017.

Greenwald D.N., Crocker-Bedford D.C., Broberg L., Suckling 
K.F., Tibbitts T. A review of northern goshawk habitat selection in the home range and implications for forest management in the western United States. - Wildlife Society Bulletin. 2005. 33: 120-129. DOI: 10.2193/0091-7648(2005)33[120:AR ONGH]2.0.CO;2 URL: https://www.biologicaldiversity.org/ publications/papers/goshawkwsb-8-05.pdf Аата обрашения: 12.12.2017.

Grier J.W., Gramlich F.J., Miattsson J., Mathisen J.E., Kussman J.V., Elder J.B., Green N.F. The bald eagle in the northern United States. - Bird conservation / S.A. Temple (Ed.). University of Wisconsin Press, Madison, WI USA, 1983: 41-66.

Grubb T.G. A survey and analysis of Bald Eagle nesting in western Washington. M.S. Thesis, Univ. of Washington, Seattle. 1976: 1-87.

Grubb T.G., Bowerman W.W., Giesy J.P., Dawson G.A. Responses of breeding bald eagles, Haliaeetus leucocephalus, to human activities in northcentral Michigan. - Canadian Field-Naturalist. 1992. 106: 443-453.

Grubb T.G., King R.M. Assessing human disturbance of breeding bald eagles with classification tree models. - The Journal of Wildlife Management. 1991. 55(3): 500-511. URL: https://www.rosemonteis.us/documents/grubb-king-1991 Аата обрашения: 12.12.2017.

Gutzwiller K.J., Marcum H.A. Bird reactions to observer clothing color: implications for distance-sampling techniques. - The Journal of Wildlife Management. 1997. 61: 935-947. DOI: 10.2307/3802203 URL: http://www.jstor. org/stable/3802203 Аата обрашения: 12.12.2017.

Habeck J.R. Dynamics of forest communities used by Great Gray Owls. - Flammulated, Boreal, and Great Gray Owls in the United States: A Technical Conservation Assessment / G.D. Hayward, J. Verner (Eds.). Gen. Tech. Rep. RM-GTR-253. Fort Collins, CO: U.S. Department of Agriculture, Forest Service, Fort Collins, CO, USA, 1994: 176-201. DOI: https://doi. org/10.2737/RM-GTR-253 URL: https://www.fs.usda.gov/ treesearch/pubs/28773 Аата обрашения: 12.12.2017.

Hakkarainen H., Mykrä S., Kurki S., Tornberg R., Jungell $S$. Competitive interactions among raptors in boreal forests. - Oecologia. 2004. 141(3): 420-4. DOI: 10.1007/s00442004-1656-6 URL: https://link.springer.com/article/10.1007\% 2Fs00442-004-1656-6 Аата обрашения: 12.12.2017.

Haller H. Zur populationsukologie des Uhus Bubo bubo im Hochgebirge: Bestand, bestandsentwicklung und Lebensraum in den Rhaetian Alps [On the population ecology of the Eagle Owl Bubo bubo in the high mountains: population numbers, trends and habitat in the Rhaetian Alps]. - Ornithologische Beobachter. 1978. 75(5/6): 237-265 (in German). URL: http://www.ala-schweiz.ch/images/stories/pdf/ ob/1978_75/OrnitholBeob_1978_75_237_Haller.pdf Дата обрашения: 12.12.2017.

Ham I. White-Tailed Eagle in Serbia, population growth and breeding success, 2008-2017. - The collection of Abstracts and Short Notes of the SEAEAGLE 2017 conference: 5-7 October Roosta, Estonia: Eagle Club Estonia, 2017: 41-42. URL: http://www.kotkas.ee/seaeagle2017/files/WTSE2017_ abstracts-and-short-notes.pdf Аата обрашения: 12.12.2017.

Haney D.L., White C.M. Habitat use and subspecific status of Merlins, Falco columbarius, wintering in central Utah. - Great Basin Naturalist. 1999. 59(3): 266-271. URL: https://scholarsarchive.byu.edu/gbn/vol59/iss3/8 Аата обрашения: 12.12.2017.

Hansen R.W. Raptor use of the Idaho National Engineering Laboratory. Master of Science thesis, South Dakota State Univ., Brookings, 1994: 1-141.

Hauff $P$. Sea Eagles in Germany and their population growth in the 20th century. - Sea Eagle 2000. Proceedings from the International Conference at Bjökö, Sweden, 13-17 September 2000 / Eds. B. Helander, M. Marquiss, W. Bowerman. Stockholm: Swedish Society for Nature Conservation, 2003: 71-78.

Haws K.V. Management recommendations for the Roseau Bog owl management unit. Minnesota Department of Natural Resources. Bemidji, Minnesota, 1987: 1-19.

Helander B. The White-Tailed Eagle in Sweden - reproduction, numbers and trends. - Sea Eagle 2000. Proceedings from the International Conference at Bjökö, Sweden, 13-17 September 2000 / Eds. B. Helander, M. Marquiss, W. Bowerman. Stockholm: Swedish Society for Nature Conservation, 2003: 57-66.

Helander B., Stjernberg T. International Species Action Plan for the White-Tailed Eagle (Haliaeetus albicilla). Strasbourg, 2003: 1-43. URL: http://www.avibirds.com/saps/EU/Europe/EN/White-tailed\%20Eagle2002.pdf Аата обрашения: 12.12.2017.

Herrmann C., Krone O., Stjernberg T., Helander B. Population development of Baltic bird species: White-Tailed Sea Eagle (Haliaeetus albicilla). - HELCOM Baltic Sea Environment Fact Sheets. 2011. URL: http://helcom.fi/baltic-seatrends/environment-fact-sheets/biodiversity/populationdevelopment-of-white-tailed-sea-eagle Аата обрашения: 12.12.2017

Holmes T.L., Knight R.L., Stegall L., Craig G.R. Responses of wintering grassland raptors to human disturbance. - Wildlife Society Bulletin. 1993. 21: 461-468. URL: http://ulpeis.anl. gov/documents/dpeis/references/pdfs/holmes_et_al_1993. pdf $\triangle$ ата обрашения: 12.12 .2017 .

Holt D.W., Berkley R., Deppe C., Enrrquez Rocha P., Petersen J.L., Rangel Salazar J.L., Segars K.P., Wood K.L., Marks J.S. Eurasian Eagle-Owl (Bubo bubo). - Handbook of the Birds of the World Alive / J. del Hoyo, A. Elliott, J. Sargatal, D.A. Christie, E. de Juana (Eds.). Lynx Edicions, Barcelona, 2017. URL: https://www.hbw.com/species/eurasian-eagle-owl-bubo-bubo Аата обрашения: 12.12.2017.

Horváth M. Habitat-and prey-selection of Imperial Eagle (Aquila heliaca). PhD thesis. Budapest, 2009: 1-119. URL: http://teo.elte.hu/minosites/ertekezes2009/horvath_m.pdf Аата обрашения: 12.12.2017.

Horváth M., Demeter I., Fatér I., Firmánszky G., Kleszó A., Kovács A., Szitta T., Tyth I., Zalai T., Bagyura J. Population Dynamics of the Eastern Imperial Eagle (Aquila heliaca) in Hungary between 2001 and 2009. - Acta zoologica bulgarica, Suppl. 3. 2011: 61-70. URL: http://www.acta-zoologica-bulgarica.eu/downloads/acta-zoologica-bulgarica/2011/ supplement-3-061-070.pdf Аата обращения: 12.12.2017.

Huff M., Henshaw J., Laws E. Great gray owl survey status and evaluation of guidelines for the Northwest Forest Plan. U.S. Department of Agriculture, Forest Service, Pacific Northwest Research Station, Forestry Sciences Laboratory, 3200 SW Jefferson Way, Corvallis, OR 97331, 1996: 1-47.

Ivanovski V.V. The current state of the nesting group of White-Tailed Eagle (Haliaeetus albicilla) at Northern Belarus. - The collection of Abstracts and Short Notes of the SEAEAGLE 2017 conference: 5-7 October Roosta, Estonia: Eagle Club Estonia, 2017: 50-51. URL: http://www.kotkas.ee/seaeagle2017/files/WTSE2017_abstracts-and-short-notes.pdf $\triangle$ ата обрашения: 12.12.2017.

Jacobson J.O. Potential impact of the Mackenzie gas pipeline on bird populations in the Yukon and Northwest Territories. - Research Reports. Vol. IV. Environmental impact assessment of the portion of the Mackenzie gas pipeline from 
Alaska to Alberta. Environmental Protection Board, Winnipeg, Manitoba, Canada. 1974: 121-176.

Johnson N.P. Nesting Bald Eagles in Urban Areas of Southeast Alaska. - Bald Eagles in Alaska / B.A. Wright and P.F. Schempf (Eds.). Juneau, Alaska, 2008: 325-343. URL: https://www.uas.alaska.edu/artssciences/docs/baldeagles-ak12-07.pdf Аата обрашения: 12.12.2017.

Jones S. The Accipiters - Goshawk, Cooper's Hawk, Sharpshinned Hawk. Habitat management series for unique or endangered species, report no. 17. U.S. Bureau of Land Management Technical Note 335. 1979: 1-51. DOI: 10.5962/ bhl.title.59373 URL: https://www.biodiversitylibrary.org/ item/121224 Аата обрашения: 12.12.2017.

Kaisanlahti-Jokimaki M., Jokimaki J., Huhta E., Ukkola M., Helle P., Ollila $T$. Territory occupancy and breeding success of the golden eagle (Aquila chrysaetos) around tourist destinations in northern Finland. - Ornis Fennica. 2008. 85: 1-11. URL: https://pdfs.semanticscholar.org/fc55/3fa5022 991b2ddd675e2fcda9a536a335d8e.pdf Аата обрашения: 12.12.2017.

Karyakin I.V., Nikolenko E.G., Levin A.S., Kovalenko A.V. Eastern Imperial Eagle in Russia and Kazakhstan: Population Status and Trends. - Acta zoologica bulgarica, Suppl. 3. 2011: 95-104. URL: http://www.acta-zoologica-bulgarica. eu/downloads/acta-zoologica-bulgarica/2011/supplement-3-095-104.pdf Аата обрашения: 12.12.2017.

Keeley W.H., Bechard M.J. Flushing distances of ferruginous hawks nesting in rural and exurban New Mexico. Journal of Wildlife Management. 2011. 75(5): 1034-1039. DOI: $10.1002 /$ jwmg.140 URL: http://www.bioone.org/doi/ abs/10.1002/jwmg.140 Аата обрашения: 12.12.2017.

Kenward R. The Goshawk. T \& AD Poyser, 2006: 1-360.

Khosravi M.R. Range Finder. - Code Project. 2009. URL: https://www.codeproject.com/Articles/35029/Range-Finder Аата обрашения: 12.12.2017.

Klute $D$. Recommended buffer zones and seasonal restrictions for Colorado raptors. - Colorado Parks \& Wildlife (CPW). Denver, 2008: 1-7. URL: https://cpw.state.co.us/ Documents/WildlifeSpecies/LivingWithWildlife/RaptorBufferGuidelines2008.pdf Аата обрашения: 12.12.2017.

Knight R. L., Knight S.K. Responses of wintering Bald Eagles to boating activity. - The Journal Wildlife Management. 1984. 48: 999-1004. DOI: 10.2307/3801456 URL: http://www.jstor.org/stable/3801456 Аата обрашения: 12.12.2017.

Knight R.L., Temple S.A. Wildlife and recreationists: coexistence through management. - Wildlife and Recreationists: Coexistence Through Management and Research / R.L. Knight, K.J. Gutzwiller Eds. Washington: Island Press, 1995: 327-333.

Kochert M., Steenhof N.K. Golden Eagles in the U.S. and Canada: status, trends, and conservation challenges. - Journal of Raptor Research. 2002. 36: 32-40. URL: http://globalraptors.org/grin/researchers/uploads/417/kochert_and_steenhof_2002.pdf Аата обрашения: 12.12.2017.

König C., Weick F. Owls of the World. Christopher Helm, London, 2008: 1-528.

Konrad P.M. Effects of management practices on grassland birds: Merlin. Northern Prairie Wildlife Research Center, Jamestown, ND, 2004: 1-20. URL: https://pubs.usgs. gov/unnumbered/70159827/report.pdf Аата обрашения: 12.12.2017.

Kostrzewa R. Die Dichte des Turmfalken (Falco tinnunculus) in Europa: Übersicht und kritische Betrachtung [Density of the Kestrel (Falco tinnunculus) in Europe: overview and critical consideration]. - Vogelwarte. 1988. 34: 216-224 (In German).
Kostrzewa R., Kostrzewa A. Der Turmfalke [The Kestrel]. Aula-Verlag, 1993: 1-133 (In German).

Kret E., Pomarède L., Ruiz C., Skartsi Th., Poirazidis K. A survey of nocturnal birds of prey in Dadia-Lefkimi-Soufli Forest National Park. Technical Report 2014. WWF Greece, Athens, 2014: 1-45. URL: https://www.wwf.gr/images/pdfs/ survey_of\%20nocturnal_\%20birds_\%20of_prey_in\%20Dadia_Lefkimi_Soufli_Forest_National_Park.pdf Аата обрашения: 12.12.2017.

Kubler S., Kupko S., Zeller U. The kestrel (Falco tinnunculus L.) in Berlin: investigation of breeding biology and feeding ecology. - Journal of Ornithology. 2005. 146(3): 271-278. URL: https://link.springer.com/article/10.1007/s10336-0050089-2 Аата обрашения: 12.12.2017.

Kumar N., Mohan D., Jhala V.Y., Qureshi Q., Sergio F. Density, laying date, breeding success and diet of Black Kite Milvus migrans govinda in the city of Delhi India. - Bird Study. 2014. 61(1): 1-18. DOI: 10.1080/00063657.2013.876972 URL: http://www.tandfonline.com/doi/abs/10.1080/000636 57.2013.876972 Аата обрашения: 12.12.2017.

Kunca $T$., Yosef $R$. Differential nest-defense to perceived danger in urban and rural areas by female Eurasian sparrowhawk (Accipiter nisus). - Peerj. 2016. 4: e2070. DOI: 10.7717/peerj.2070 URL: https://www.ncbi.nlm.nih.gov/ pmc/articles/PMC4941787 Аата обрашения: 12.12.2017.

Kuznetsov A.V., Babushkin M.V., Galushin V.M. History of formation and modern state of inland population of whitetailed eagle on large waterbodies of Russian North-West. The collection of Abstracts and Short Notes of the SEAEAGLE 2017 conference: 5-7 October Roosta, Estonia: Eagle Club Estonia, 2017: 62-63. URL: http://www.kotkas.ee/seaeagle2017/files/WTSE2017_abstracts-and-short-notes.pdf $\triangle$ aтa обрашения: 12.12.2017.

Larsen E., Azerrad J. M., Nordstrom N. Eds. Management recommendations for Washingtons priority species, Volume IV: Birds. Washington Department of Fish and Wildlife, Olympia, Washington, USA, 2004. URL: https://wdfw.wa.gov/ publications/00026/wdfw00026.pdf Аата обрашения: 12.12.2017.

León-Ortega M., Peréz E., Lacalle J.A., Martínez J.E., Calvo J.F. Monitoring, ringing and demographic parameters of two Eurasian Eagle Owl populations in the Iberian Southeast. Book of abstracts: World Owl Conference 2017, Évora, Portugal, 26 to 30 September 2017. University of Évora, 2017: 101. URL: http://www.woc2017.uevora.pt/wp-content/uploads/2017/11/WOC2017-ABSTRACTS.pdf Аата обрашения: 12.12.2017.

Levenson $\mathrm{H}$. Time and activity budgets of Ospreys nesting in northern California. - Condor. 1979. 81: 364-369. URL: https://sora.unm.edu/sites/default/files/journals/condor/ v081 n04/p0364-p0369.pdf Аата обрашения: 12.12.2017.

Levenson H., Koplin J.R. Effects of human activity on productivity of nesting ospreys. - The Journal Wildlife Management. 1984. 48: 1374-1377. DOI: $10.2307 / 3801800$ URL: http://www.jstor.org/stable/3801800 Аата обрашения: 12.12.2017.

Lipsbergs J., Bergmanis $U$. Recent population status and conservation measures for the White-Tailed Sea Eagle in Latvia. - Sea Eagle 2000. Proceedings from the International Conference at Bjökö, Sweden, 13-17 September 2000 / Eds. B. Helander, M. Marquiss, W. Bowerman. Stockholm: Swedish Society for Nature Conservation, 2003: 91-96.

Literak I., Horal D., Alivizatos H., Matusik H. Common wintering of black kites (Milvus migrans migrans) in Greece, and 
new data on their wintering elsewhere in Europe. - Slovak Raptor Journal. 2017. 11: 91-102. DOI: 10.1515/srj-20170001.

Livezey K.B., Fernandez-Juricic E., Blumstein D.T. Database of bird flight initiation distances to assist in estimating effects from human disturbance and delineating buffer areas. - Journal of Fish and Wildlife Management. 2016. 7(1): 181-191. e1944-687X. DOI: 10.3996/082015-JFWM-078 URL: $\quad$ http://fwspubs.org/doi/pdf/10.3996/082015-JFWM078? code=ufws-site $\Delta$ ата обрашения: 12.12.2017.

Lohmus A. Are timber harvesting and conservation of nest sites of forest-dwelling raptors always mutually exclusive? - Animal Conservation. 2005. 8: 443-450. DOI: 10.1017/ S1367943005002349 URL: http://onlinelibrary.wiley.com/ doi/10.1017/S1367943005002349/full Аата обрашения: 12.12.2017.

Maciorowski G. Numbers, trends, reproductive success, hybrydization and monitoring of the Greater Spotted Eagle Aquila clanga in Poland. - Conservation of the Greater Spotted Eagle. Proceedings of the International Workshop. Goniądz, Poland 25-27 th January 2012. Goniądz, 2012: 7. URL: http://orlikgrubodzioby.org.pl/public/file/pdf/Conservation_of_the_Greater_Spotted_Eagle.pdf Аата обрашения: 12.12.2017.

Maciorowski G., Lontkowski J., Mizera T. The Spotted Eagle - Vanishing Bird of the Marshes. Poznan, 2014: 1-308. URL: http://rrrcn.ru/en/archives/22598 Аата обрашения: 12.12.2017.

Madders M., Whitfield D.P. Upland raptors and the assessment of wind farm impacts. - Ibis. 2006. 148: 43-56. DOI: 10.1111/j.1474-919X.2006.00506.x URL: http://onlinelibrary.wiley.com/doi/10.1111/j.1474-919X.2006.00506.x/ abstract Аата обращения: 12.12.2017.

Marchant S., Higgins P.J. (Eds.). Handbook of Australian, New Zealand and Antarctic Birds: Volume 2: Raptors to Lapwings (Handbook of Australian, New Zealand \& Antarctic Birds). Melbourne: Oxford University Press, 1993: 1-1048.

Marchesi L., Sergio F., Pedrin P. Costs and benefits of breeding in human-altered landscapes for the Eagle Owl Bubo bubo. - Ibis. 2002. 144(4): 164-177. DOI: 10.1046/j.1474919X.2002.t01-2-00094_2.x URL: http://onlinelibrary.wiley. com/doi/10.1046/j.1474-919X.2002.t01-2-00094_2.x/full Аата обрашения: 12.12.2017.

Marquiss M., Ratcliffe D.A., Roxburgh R. The numbers, breeding success and diet of Golden Eagles in southern Scotland in relation to changes in land use. - Biological Conservation. 1985. 33: 1-17. DOI: 10.1016/0006-3207(85)901041 URL: https://www.sciencedirect.com/science/article/ pii/0006320785901041 Аата обращения: 12.12.2017.

Marzluff J.M., Knick S.T., Vekasy M.S., Scheuck L.S., Zarriello T.J. Spatial use and habitat selection of golden eagles in southwestern Idaho. - The Auk. 1997. 114: 673-687. DOI: 10.2307/4089287 URL: https://sora.unm.edu/sites/ default/files/journals/auk/v114n04/p0673-p0687.pdf $\Delta$ ата обрашения: 12.12 .2017$.

Mathison J.E., Sorenson D.S., Frenzel L.D., Stan T.C.D. Management strategy for Bald Eagles. - Transactions of the North American Wildlife and Natural Resources Conference. 1977. 42: 86-92. URL: https://wildlife-management-institute. myshopify.com/products/transactions-of-the-42nd-northamerican-wildlife-and-natural-resources-conference $\Delta$ ата обрашения: 12.12.2017.

McGarigal K., Anthony R.C., Isaacs F.B. Interactions of humans and Bald Eagles on the Columbia River estuary. - Wildlife Monographs. 1991. 115: 1-47.
McGrady M.J., McLeod D.R.A., Petty S.J., Grant J.R., Bainbridge I.P. Golden Eagles and Forestry. Research Information Note 292. Forestry Commission, Farnham, UK, 1997: 1-8. URL: http://scotland.forestry.gov.uk/images/corporate/pdf/ RIN292.pdf Аата обрашения: 12.12.2017.

McGrady M.J., Petty S.J. Golden Eagles and New Native Woodland in Scotland. Forestry Commission Information Note. 71. Edinburgh, 2005: 1-6. URL: https://www.forestry. gov.uk/pdf/fcin071.pdf/\$FILE/fcin071.pdf Аата обрашения: 12.12.2017.

McGrady M.J., Petty S.J., McLeod D.R.A. Potential impacts of new native woodland expansion on golden eagles in Scotland. Scottish Natural Heritage Commissioned Report No. 018 (ROAME No. F99LD01). 2004: 1-58. URL: http:// www.snh.org.uk/pdfs/publications/commissioned_reports/ no.\%20018.pdf Аата обрашения: 12.12.2017.

Mersmann T.J., Fraser J.D. Management of raptor foraging habitat in the southeast. - Proceedings of the Southeast Raptor Management Symposium and Workshop. National Wildlife Federation Science and Technical Series Number 14 / B.G. Pendleton, M.B. Moss, M.N. LeFranc Jr., B.A. Millsap (Eds). Washington, DC, 1990: 189-198.

Meyburg B.-U., Manowsky O., Meyburg C. Breeding success of tree- and pylon-nesting Ospreys Pandion haliaetus in Germany. - Vogelwelt, 1995. 116: 219-224. (in German with English summary). URL: http://www.raptor-research.de/ pdfs/a_rp500p/a_rp511.pdf Аата обрашения: 12.12.2017.

Mikkola-Roos M., Tiainen J., Below A., Hario M., Lehikoinen A., Lehikoinen E., Lehtiniemi T., Rajasärkkä A., Valkama J., Väisänen R.A. Birds. - The 2010 Red List of Finnish Species 2010 / P. Rassi, E. Hyvärinen, A. Juslén, I. Mannerkoski (Eds.). Helsinki, 2010: 320-331. URL: http://www.ym.fi/ fi-Fl/Ajankohtaista/Julkaisut/Erillisjulkaisut/Suomen_lajien_uhanalaisuus_Punainen_kir(4709) Аата обрашения: 12.12.2017.

Mikula P. Pedestrian Density Influences Flight Distances of Urban Birds. - Ardea. 2014. 102(1): 53-60. DOI: 10.5253/078.102.0105 URL: http://www.bioone.org/doi/ abs/10.5253/078.102.0105 Аата обрашения: 12.12.2017.

Mizera T. White-Tailed Sea Eagle in Poland. - Sea Eagle 2000. Proceedings from the International Conference at Bjökö, Sweden, 13-17 September 2000 / Eds. B. Helander, M. Marquiss, W. Bowerman. Stockholm: Swedish Society for Nature Conservation, 2003: 79-84.

Møller A.P. Up, up, and away: relative importance of horizontal and vertical escape from predators for survival and senescence. - Journal of Evolutionary Biology. 2010. 23: 1689-1698. DOI: 10.1111/j.1420-9101.2010.02034.x URL: http://onlinelibrary.wiley.com/doi/10.1111/j.14209101.2010.02034.x/full Аата обращения: 12.12.2017.

Møller A.P. Urban areas as refuges from predators and flight distance of prey. - Behavioral Ecology. 2012. 23(5): 1030-1035. DOI: 10.1093/beheco/ars067 URL: https:// academic.oup.com/beheco/article/23/5/1030/232976 Аата обрашения: 12.12.2017.

Møller A.P., Erritzøe J. Flight Distance and Eye Size in Birds. - Ethology. 2010. 116: 458-465. DOI: 10.1111/j.14390310.2010.01754.x URL: http://www.birdresearch.dk/unilang/Moeller_Erritzoe_Ethology_2010.pdf Аата обрашения: 12.12.2017.

Møller A.P., Samia D.S.M., Weston M.A., Guay P.-J., Blumstein D.T. American Exceptionalism: Population Trends and Flight Initiation Distances in Birds from Three Continents. - PLoS ONE. 2014. 9(9): e107883. DOI:10.1371/journal.pone.0107883 URL: http://journals.plos.org/plosone/ 
article?id=10.1371/journal.pone.0107883 $\Delta$ ата обрашения: 12.12.2017.

Morris D.L., Porneluzi P.A., Haslerig J., Clawson R.L., Faaborg J. Results of 20 years of experimental forest management on breeding birds in Ozark forests of Missouri, USA. Forest Ecology and Management. 2013. 310: 747-760. DOI: 10.1016/j.foreco.2013.09.020 URL: https://www.deepdyve. com/lp/elsevier/results-of-20-years-of-experimental-forestmanagement-on-breeding-PVUrzTpaXO Аата обрашения: 12.12.2017.

Moss E. Golden eagle (Aquila chrysaetos) ecology and forestry. Introductory Research Essay No. 10. Umeå, Sweden: Department of Wildlife, Fish, and Environmental Studies Swedish University of Agricultural Sciences, 2011: 1-31. URL: https://pub.epsilon.slu.se/8368/1/Moss_E_111013.pdf Аата обрашения: 12.12.2017.

Natsukawa H., Ichinose T., Higuchi H. Factors Affecting Breeding-Site Selection of Northern Goshawks at Two Spatial Scales in Urbanized Areas. - Journal of Raptor Research. 2017. 51(4): 417-427. DOI: 10.3356/JRR-16-69.1 URL: http://www.bioone.org/doi/abs/10.3356/JRR-16-69.1 Аата обрашения: 12.12.2017.

Naylor B.J. Managing wildlife habitat in red pine and white pine forests of central Ontario. - Forestry chronicle. 1994. 70: 411-419. URL: https://geoscience.net/ research/002/651/002651375.php Аата обрашения: 12.12.2017.

Naylor B., Simard J., Alkins M., Lucking G., Watt B. Effects of forest managementpractices on breeding ospreys and great blue herons in the boreal and Great Lakes - St.Lawrence forests of Ontario. OMNR SCS Tech. Rpt. 2003: 1-24. URL: http://www.forestresearch.ca/Projects/other/ospreyheron. pdf Аата обрашения: 12.12.2017.

Naylor B., Watt B. Review of the Forest Management Guidelines for BaldEagles, Ospreys, and Great Blue Herons in Ontario. 2004: 1-66. URL: http://www.ontla.on.ca/library/repository/mon/13000/257547.pdf Аата обрашения: 12.12.2017.

Newton I. Population Ecology of Raptors. T. \& A.D. Poyser, Berkhamsted, UK, 1979: 1-432.

Newton I. The Sparrowhawk. T. \& A. D. Poyser, 1986: $1-424$.

Nordell C.J. Ferruginous Hawk (Buteo regalis) responses to human disturbance during the breeding season. Thesis of Master of Science in Ecology. Department of Biological Sciences, University of Alberta, 2016: 1-88. URL: https://era.library. ualberta.ca/files/c5d86p026n/Nordell_Cameron_J_201602_ MSc.pdf Аата обрашения: 12.12.2017.

Olendorff R.R., Stoddard J.W. Jr. The potential for management of raptor populations in western grasslands. - Management of raptors. Raptor Research Report No. 2 / F.N. Hamerstrom Jr., B.E. Harrell, R.R. Olendorff, Eds. Raptor Research Foundation, Inc. Vermillion, South Dakota, 1974: 47-88.

Olendorff R.R., Zeedyk W.D. Land management for the conservation of endangered birds. - Endangered birds / S.A. Temple, Ed. University of Wisconsin Press, Madison, Wisconsin, 1978: 419-428.

Olsson V. Studies on a population of Eagle Owls, Bubo bubo (L.), in southeast Sweden. - Viltrevy. 1979. 11(1): 3-99.

OMNR. Forest Management Guide for Conserving Biodiversity at the Stand and Site Scales - Background and Rationale for Direction. Toronto: Queen's Printer for Ontario, 2010: 1-575. URL: https://dr6j45jk9xcmk.cloudfront.net/ documents/2787/guide-standsitescales-bkgndrational-aoda. pdf Аата обрашения: 12.12.2017.
Ontario Ministry of Natural Resources. Bald Eagle Habitat Management Guidelines. Ontario, 1987: 1-15. URL: https:// dr6j45jk9xcmk.cloudfront.net/documents/2789/guide-baldeagle.pdf Аата обрашения: 12.12.2017.

Penak B. Management guidelines and recommendations for Osprey in Ontario. Ontario Ministry of Natural Resources, 1983: 1-34. URL: https://dr6j45jk9xcmk.cloudfront. net/documents/2802/guide-osprey.pdf $\Delta$ aта обрашения: 12.12.2017.

Penteriani $V$. Goshawk nesting habitat in Europe and North America: A review. - Ornis Fennica. 2002. 79: 149-163. URL: https://lintulehti.birdlife.fi:8443/pdf/artikkelit/312/tiedosto/of_79_149-163_artikkelit_312.pdf Аата обращения: 12.12.2017.

Penteriani V., Faivre B. Effects of harvesting timber stands on goshawk nesting in two European areas. - Biological Conservation. 2001. 101: 211-216. DOI: 10.1016/ s0006-3207(01)00068-4 URL: http://digital.csic.es/bitstream/10261/62305/1/biocon.pdf Аата обрашения: 12.12.2017.

Peregrine Falcon habitat management guidelines Ontario Ministry of Natural Resources. 1987: 1-10. URL: https://dr6j45jk9xcmk.cloudfront.net/documents/2803/guide-peregrine.pdf Аата обрашения: 12.12.2017.

Peške L. Populace krahujce obecnŭho (Accipiter nisus) v Praze. - Dravci 1985. Zbornik prednasek, Prerov, 1987: 151-160. [Peške L. Population of Euroasian Sparrowhawk (Accipiter nisus) in Prague. - Birds of prey 1985 / J. Sitko, P. Trpák (Eds.). Prerov, 1987: 151-160 (In Czech).] URL: http:// www.tkv.cz/pdf/sbornik/dravci/1985_151_160.pdf $\triangle$ Аата обрашения: 12.12.2017.

Peške L. Philopatry in Sparrowhawks (Accitpiter nisus): Dispersal, breeding site fidelity and winter movements of Sparrowhawks living in Prague. - Buteo (Suppl.). 1999: 11-12.

Petty S.J. Reducing the disturbance to goshawks during the breeding season. - Forestry Commission Research Information Note 267. Edinburgh, 1996: 1-8. URL: https://www. forestry.gov.uk/pdf/RIN267.pdf/\$FILE/RIN267.pdf $\quad \Delta$ ата обрашения: 12.12.2017.

Petty S.J. Ecology and conservation of raptors in forests. - Forestry Commission Bulletin 118. London, 1998: 1-45. URL: https://www.forestry.gov.uk/PDF/FCBU1 18.pdf/\$FILE/ FCBU1 18.pdf Аата обрашения: 12.12.2017.

Piechocki R. Der Turmfalke [The Common Kestrel]. Neue Brehm-Bıcherei no. 116. Westarp Wissenschaften, Hohenwarsleben, Germany, 2008: 1-164 (In German).

Poole A.F. Ospreys: a natural and unnatural history. Cambridge, 1989a: 1-270.

Poole A.F. The effects of human disturbance on Osprey reproductive success. - Colonial Waterbirds. 1989b. 4: 20-27.

Pongracz A., Horvath M. Suggested methodology for temporal and long-term spatial restrictions of human activities around the nests of strictly protected raptors, owls and black storks. - Heliaca. 2010. 8: 104-107. URL: http://mme.hu/ binary_uploads/2_magunkrol/heliaca/heliaca_2010_online. pdf Аата обрашения: 12.12.2017.

Porneluzi P.A., Brito-Aguilar R., Clawson R.L., Faaborg J. Long-term dynamics of bird use of clearcuts in post-fledging period. - The Wilson Journal of Ornithology. 2014. 126(4): 623-634. DOI: 10.1676/14-002.1 URL: http://www. bioone.org/doi/abs/10.1676/14-002.1. Аата обрашения: 12.12.2017.

Probst R. Der Baumfalke (Falco subbuteo) in Kärnten. Eine inneralpine Studie zur Ökologie des Kleinfalken [The Hobby 
(Falco subbuteo) in Carinthia]. - Naturwissenschaftlicher Verein für Kärnten, 64. Sonderheft, Klagenfurt, 2013: 1-256. URL: http://www.zobodat.at/pdf/CAR-SH_64_0001-0256. pdf $\triangle$ ата обрашения: 12.12.2017.

Probst R., Pichler C. The White-Tailed Eagle in Austria: distribution and numbers, productivity, and migration. - The collection of Abstracts and Short Notes of the SEAEAGLE 2017 conference: 5-7 October Roosta, Estonia: Eagle Club Estonia, 2017: 91-92. URL: http://www.kotkas.ee/seaeagle2017/files/WTSE2017_abstracts-and-short-notes.pdf $\triangle$ ата обрашения: 12.12.2017.

Quigley T.M., Haynes R.W., Graham R.T. Integrated scientific assessment for ecosystem management in the interior Columbia Basin and portions of the Klamath and Great Basins. Gen. Tech. Rep. PNW-GTR-382. Portland, Oregon: USDA Forest Service Pacific Northwest Research Station, 1996: 1-303. URL: https://www.fs.usda.gov/treesearch/pubs/25384 $\Delta$ ата обрашения: 12.12.2017.

Radler K., Bergerhausen $W$. On the life history of a reintroduced population of Eagle Owls (Bubo bubo). - Proceedings of the International Symposium on Raptor Reintroductions, 1985: held in association with the Annual Meeting of the Raptor Research Foundation, Inc., 12 November 1985 / D.K. Garcelon, G.W. Roemer (Eds). California: Institute of Wildlife Studies, 1988. 83-94. URL: http://egeeulen.de/files/ publikationen/population_eagleowls.pdf Аата обрашения: 12.12.2017.

Reiser M.H., Ward J.P. Jr. Habitat Structure of Bald Eagle Nest Sites and Management Zones near Juneau, Alaska. Bald Eagles in Alaska / B.A. Wright and P.F. Schempf (Eds.). Juneau, Alaska, 2008: 344-353. URL: https://www.uas. alaska.edu/artssciences/docs/bald-eagles-ak12-07.pdf $\Delta$ ата обрашения: 12.12.2017.

Reynolds R.T. Management of western coniferous forest habitat for nesting Accipiter hawks. USDA Forest Service, General Technical Report RM-102. 1983: 1-11. URL: https://www.fs.fed.us/rm/pubs_rm/rm_gtr102.pdf Аата обрашения: 12.12 .2017$.

Reynolds R.T., Graham R.T., Reiser M.H., Bassett R.L., Kennedy P.L., Boyce D.A., Goodwin G., Smith R., Fisher E.L. Management recommendations for the northern goshawk in the southwestern United States. USDA Forest Service General Technical Report RM-217. 1992: 1-93. URL: http:// openknowledge.nau.edu/2521/1/Reynolds_R_etal_1992_ ManagementRecommendationsForTheNorthern.pdf $\quad \Delta$ ата обрашения: 12.12.2017.

Richardson C.T., Miller C.K. Recommendations for protecting raptors from human disturbance: a review. - Wildlife Society Bulletin. 1997. 25: 634-638. URL: http://www.cosb.us/ Solargen/feir/v2/b026refs/Richardson\%20and\%20Miller\%20 1997\%20Reccomendations\%20for\%20protecting\%20ra.pdf $\triangle$ ата обрашения: 12.12.2017.

Richter D.J. Territory occupancy, reproductive success and nest site characteristics of goshawks on managed timberlands in central and northern California 1993-2000. - California Fish and Game. 2005. 91(2): 100-118.

Roberge J-M., Angelstam P. Usefulness of the umbrella species concept as a conservation tool. - Conserv. Biol. 2004. 18: 76-85. DOI: 10.1111/j.1523-1739.2004.00450.x URL: http://onlinelibrary.wiley.com/doi/10.1111/j.15231739.2004.00450.x/abstract Аата обращения: 12.12.2017.

Rodgers J., Schwikert S. Buffer-zone distances to protect foraging and loafing waterbirds from disturbance by personal watercraft and outboard-powered boats. - Conservation Biology. 2002. 16: 216-224. DOI: 10.1046/j.1523- 1739.2002.00316.x URL: http://obpa-nc.org/ DOI-AdminRecord/0053052-0053060.pdf Аата обрашения: 12.12.2017.

Rodgers J.A., Smith H.T. Set-back distances to protect nesting bird colonies from human disturbance in Florida. - Conservation Biology. 1995. 9: 89-99. DOI: 10.1046/j.15231739.1995.09010089.x URL: http://fwcg.myfwc.com/ docs/wading_bird_setback_limits.pdf Аата обрашения: 12.12.2017.

Rodgers J.A., Smith H.T. Buffer zone distances to protect foraging and loafing waterbirds from human disturbance in Florida. - Wildlife Society Bulletin. 1997. 25: 139-145. URL: http://obpa-nc.org/DOI-AdminRecord/0048818-0048824. pdf Аата обрашения: 12.12.2017.

Rodrick E., Milner R. Management Recommendations for Washington's Priority Habitats and Species. Washington Department of Wildlife, Olympia, 1991: 1-207. URL: https:// wdfw.wa.gov/publications/00032/wdfw00032.pdf $\quad$ Аата обрашения: 12.12.2017.

Rodriguez S.A., Kennedy P.L., Parker T.H. Timber harvest and tree size near nests explains variation in nest site occupancy but not productivity in northern goshawks (Accipiter gentilis). - Forest Ecology and Management. 2016. 374: 220229. DOI: 10.1016/j.foreco.2016.04.052 URL: https://www. sciencedirect.com/science/article/pii/S0378112716302328 $\triangle$ ата обрашения: 12.12.2017.

Romin L.A., Muck J.A. Utah field office guidelines for raptor protection from human and land use disturbances. U.S. Fish and Wildlife Service, Utah Field Office, Salt Lake City, 2002: 1-42. URL: https://www.fws.gov/utahfieldoffice/Documents/MigBirds/Raptor\%20Guidelines\%20(v\%20March\%20 20,\%202002).pdf Аата обрашения: 12.12.2017.

RRRCN. Raptors of the World. Version 1.3. Sibecocenter LLC. 2017. Occurrence Dataset https://doi.org/10.15468/ fggsfn accessed via GBIF.org on 2017-12-18.

Richardson C.T., Miller C.K. Recommendations for protecting raptors from human disturbance: a review. - Wildlife Society Bulletin. 1997. 25: 634-638. URL: http://www.cosb.us/ Solargen/feir/v2/b026refs/Richardson\%20and\%20Miller\%20 1997\%20Reccomendations\%20for\%20protecting\%20ra.pdf Аата обращения: 12.12.2017.

Ruddock M., Whitfield D.P. A Review of Disturbance Distances in Selected Bird Species (A report from Natural Research (Projects) Ltd to Scottish Natural Heritage). Edinburgh, 2007: 1-181. URL: http://www.snh.org.uk/pdfs/strategy/ renewables/birdsd.pdf $\Delta$ ата обрашения: 12.12.2017.

Rudnicky T.C., Hunter M.L. Reversing the fragmentation perspective: effects of clearcut size on bird species richness in Maine. - Ecological Applications. 1993. 3: 357-366. URL: https://www.ncbi.nlm.nih.gov/pubmed/27759314 Аата обрашения: 12.12.2017.

Rutz C. Post-fledging dispersal of Northern Goshawks (Accipiter gentilis) in an urban environment. - Vogelwelt. 2003. 124: 93-101. URL: http://users.ox.ac.uk/ kgroup/publications/pdf/Rutz\%202003\%20Vogelwelt\%20124.pdf обрашения: 12.12.2017.

Rutz C. Breeding season diet of Northern Goshawks Accipiter gentilis in the city of Hamburg, Germany. - Corax. 2004). 19: 311-322. URL: http://users.ox.ac.uk/ kgroup/ publications/pdf/Rutz\%202004\%20Corax\%2019.pdf Аата обрашения: 12.12.2017.

Rutz C., Bijlsma R.G., Marquiss M., Kenward R.E. Population limitation in the northern goshawk in Europe: a review with case studies. - Studies in Avian Biology. 2006. 31: 158-197. URL: https://www.researchgate.net/publi- 
cation/281389874_Population_limitation_in_the_Northern_Goshawk_in_Europe_A_review_with_case_studies $\Delta$ ata обрашения: 12.12.2017.

Saga O., Selas V. Nest reuse by Goshawks after timber harvesting: Importance of distance to logging, remaining mature forest area and tree species composition. - Forest Ecology and Management. 2012. 270: 66-70. DOI: 10.1016/j. foreco.2012.01.015 URL: https://www.sciencedirect.com/ science/article/pii/SO378112712000254 Аата обрашения: 12.12.2017.

Santangeli A., Lehtoranta H., Laaksonen T. Successful voluntary conservation of raptor nests under intensive forestry pressure in a boreal landscape. - Animal Conservation. 2012. 15: 571-578. DOI: 10.1111/j.14691795.2012.00551.x URL: http://onlinelibrary.wiley.com/ doi/10.1111/j.1469-1795.2012.00551.x/abstract Аата обрашения: 12.12.2017.

Saurola $P$. Rengastettujen petolintujemme löytymistavat [Finding details of raptors and owls ringed in Finland]. - Lintumies. 1979. 14: 15-21 (In Finnish).

Saurola P.L. The osprey (Pandion haliaetus) and modern forestry: a review of population trends and their causes in Europe. - Journal of Raptor Research. 1997. 31: 129-137.

Schirato G., Parsons W. Bald eagle management in urbanizing habitat of Puget Sound, Washington. - Northwestern Naturalist. 2006. 87: 138-142.

Schmidt-Rothmund D., Dennis R., Saurola P. The Osprey in the Western Palearctic: Breeding Population Size and Trends in the Early $21^{\text {st }}$ Century. - Journal of Raptor Research. 2014. 48 (4): 375-386. DOI: 10.3356/JRR-13-OSPR-13-03.1 URL: http://www.bioone.org/doi/full/10.3356/JRR-13-OSPR-13-03.1 Аата обрашения: 12.12.2017.

Selas V. Nest-site selection by four sympatric forest raptors in southern Norway. - Journal of Raptor Research. 1997. 31 (1): 16-25. URL: https://sora.unm.edu/sites/default/files/ journals/jrr/v031n01/p00016-p00025.pdf Аата обрашения: 12.12.2017.

Selas V., Steen O.F., Johnsen J.T. Goshawk breeding densities in relation to mature forest in southeastern Norway. Forest Ecology and Management. 2008. 256: 446-451. DOI: 10.1016/j.foreco.2008.04.047 URL: https://www.sciencedirect.com/science/article/pii/S0378112708003885 Аата обрашения: 12.12 .2017 .

Sergio F., Newton I., Marchesi L., Pedrini P. Ecologically justified charisma: preservation of top predators delivers biodiversity conservation. - Journal of Applied Ecology. 2006. 43(6): 1049-1055. DOI: 10.1111/j.1365-2664.2006.01218.x URL: http://onlinelibrary.wiley.com/doi/10.1111/j.13652664.2006.01218.x/full Аата обрашения: 12.12.2017.

Sergio F, Pedrini P, Marchesi L. Adaptive selection of foraging and nesting habitat by black kites (Milvus migrans) and its implications for conservation: a multi-scale approach. - Biological Conservation. 2003. 112: 351-362. DOI: 10.1016/ S0006-3207(02)00332-4 URL: https://www.researchgate. net/publication/222042051_Adaptive_selection_of_foraging_and_nesting_habitat_by_black_kites_Milvus_migrans_ and_its_implications_for_conservation_A_multi-scale_approach Аата обрашения: 12.12.2017.

Sergio F., Scandolara C., Marchesi L., Pedrini P., Penteriani $V$. Effect of agro-forestry and landscape changes on common buzzards (Buteo buteo) in the Alps: implications for conservation. - Animal Conservation. 2005. 7: 17-25. DOI:10.1017/ S1367943004001623 URL: http://onlinelibrary.wiley. com/doi/10.1017/S1367943004001623/abstract Аата обрашения: 12.12 .2017$.
Smith T.J. The effect of human activities on the distribution and abundance of the Jordan Lake-Falls Lake Bald Eagles. M. S. Thesis, Virginia Polytechnic Inst. and State Univ., Blacksburg, VA, 1988: 1-100.

Sodhi N.S. Growth of nestling Merlins, Falco columbarius. Canadian Field-Naturalist. 1992. 106: 387-389.

Solheim R., Sonerud G.A., Strøm H. Home range, perch heights and reactions to approaching humans by three radiotagged Ural Owls. - Book of abstracts: World Owl Conference 2017, Évora, Portugal, 26 to 30 September 2017. University of Évora, 2017: 76. URL: http://www.woc2017.uevora.pt/ wp-content/uploads/2017/11/WOC2017-ABSTRACTS.pdf $\triangle$ ата обрашения: 12.12.2017.

Solonen T. Larger broods in the Northern Goshawk Accipiter gentilis near urban areas in southern Finland. - Ornis Fennica. 2008. 85: 118-125. URL: https://lintulehti.birdlife. fi:8443/pdf/artikkelit/180/tiedosto/of_85_118-125_artikkelit_180.pdf $\triangle$ ата обрашения: 12.12.2017.

Spaul R.J., Heath J.A. Nonmotorized recreation and motorized recreation in shrub-steppe habitats affects behavior and reproduction of golden eagles (Aquila chrysaetos). - Ecology and Evolution. 2016. 6 (22): 8037-8049. DOI: 10.1002/ ece3.2540 URL: https://www.ncbi.nlm.nih.gov/pmc/articles/PMC5108256 Аата обрашения: 12.12.2017.

Spaul R.J., Heath J.A. Flushing Responses of Golden Eagles (Aquila chrysaetos) In Response To Recreation. - The Wilson Journal of Ornithology. 2017. 129 (4): 834-845. DOI: 10.1676/16-165.1 URL: https://www.researchgate.net/publication/322256075_Flushing_Responses_of_Golden_Eagles_Aquila_chrysaetos_In_Response_To_Recreation $\triangle$ Ата обрашения: 12.12.2017.

Squires J.R., Kennedy P.L. Northern Goshawk ecology: An assessment of current knowledge and information needs for conservation and management. - Studies in Avian Biology. 2006. 31: 8-62. URL: https://www.fs.usda.gov/treesearch/ pubs/50153 Аата обращения: 12.12.2017.

Squires J.R., Reynolds R.T. Northern Goshawk (Accipiter gentilis), version 2.0. - The Birds of North America / P. G. Rodewald, ed. Cornell Lab of Ornithology, Ithaca, New York, USA, 1997. DOI: 10.2173/bna.298 URL: https://birdsna.org/Species-Account/bna/species/norgos Аата обрашения: 12.12.2017.

Stalmaster M.V., Kaiser J.L. Effects of recreational activity on wintering Bald Eagles. - Wildlife Monographs. 1997. 137: 5-46. URL: https://www.cabdirect.org/cabdirect/abstract/19981807116 Аата обрашения: 12.12.2017.

Stalmaster M.V., Newman J.R. Behavioral responses of wintering Bald Eagles to human activity. - The Journal of Wildlife Management. 1978. 42: 506-513. DOI: 10.2307/3800811 URL: http://www.jstor.org/stable/3800811 Аата обрашения: 12.12.2017.

Steenhof K., Kochert M.N., Doremus J.H. Nesting of subadult Golden eagles in southwestern Idaho. - Auk. 1983. 100 (3): 743-747. URL: http://www.jstor.org/stable/4086483 Аата обрашения: 12.12.2017.

Steidl R.J., Anthony R.G. Experimental effects of human activity on breeding bald eagles. - Ecological Applications. 2000. 10: 258-268. URL: https://cals.arizona.edu/ steidl/ files/pdfs/Steidl\%20and\%20Anthony\%202000\%20EA.pdf $\triangle$ ата обрашения: 12.12.2017.

Steidl R.J., Kozie K.D., Dodge G.J., Pehovski T., Hogan E.R. Effects of human activity on breeding behaviour of Golden Eagles in Wrangell-Saint Elias National Park and Preserve: a preliminary assessment. - Research and Resource Management Report 93-3. Copper Centre, Alaska: Wrangell-Saint Elias National Park and Preserve. 1993. 
Stephens R.M., Anderson S.H. Conservation Assessment for the Merlin in the Black Hills National Forest, South Dakota and Wyoming. Custer, South Dakota, 2002: 1-25. URL: https://www.fs.usda.gov/Internet/FSE_DOCUMENTS/stelprdb5226884.pdf Аата обрашения: 12.12.2017.

Stjernberg T. Protection of nesting areas of the White-Tailed Sea Eagle in Finland. - Sea Eagle 2000. Proceedings from the International Sea Eagle Conference. 2003: 355-363.

Stjernberg T., Koivusaari J., Högmander J., Ollila T., Keränen S., Munsterhjelm G., Ekblom H. Population size and nesting success of the White-tailed Sea Eagle (Haliaeetus albicilla) in Finland, 2007-2008. - Linnut-vuosikirja 2008. 2009: 14-21. URL: https://lintulehti.birdlife.fi:8443/pdf/artikkelit/1902/tiedosto/ Merikotka_artikkelit_1902.pdf Аата обрашения: 12.12.2017.

Strasser E.H. Reproductive Failure and the Stress Response in American Kestrels Nesting Along a Human Disturbance Gradient. Master of Science Thesis. Boise State University, 2010: 1-86. URL: http://scholarworks.boisestate.edu/td/86 $\triangle$ ата обрашения: 12.12.2017.

Strasser E.H., Heath J.A. Reproductive failure of a humantolerant species, the American kestrel, is associated with stress and human disturbance. - Journal of Applied Ecology. 2013. 50: 912-919. DOI: 10.1111/1365-2664.12103 URL: http://onlinelibrary.wiley.com/doi/10.1111/13652664.12103/pdf Аата обрашения: 12.12.2017.

Suarez S., Balbontin J., Ferrer M. Nesting habitat selection by booted eagles Hieraaetus pennatus and implications for managemen. - Journial of Applied Ecologjy. 2000. 37: 215223. DOI: $10.1046 /$ j.1365-2664.2000.00503.x URL: http:// www.globalraptors.org/grin/researchers/uploads/192/ suarez,_s._et_al._2000.pdf $\Delta$ ата обрашения: 12.12.2017.

Sulkava S., Huhtala K. The Great Gray Owl (Strix nebulosa) in the changing forest environment of northern Europe. Jounal of Raptor Research. 1997. 31(2): 151-159. URL: https://sora.unm.edu/sites/default/files/journals/jrr/v031n02/ p00151-p00159.pdf Аата обрашения: 12.12.2017.

Sunde P., Odderskær P., Storgaard K. Flight distances of incubating Common Buzzards Buteo buteo are independent of human disturbance. - Ardea. 2009. 97(3): 369-372. DOI: 10.5253/078.097.0313 URL: https://www.researchgate.net/ publication/232666061_Flight_Distances_of_Incubating_ Common_Buzzards_Buteo_buteo_are_Independent_of_Human_Disturbance Аата обрашения: 12.12.2017.

Suter II G.W., Jones J.L. Criteria for golden eagle, ferruginous hawk, and prairie falcon nest site protection. - Raptor Research. 1981. 15(1): 12-18. URL: https://sora.unm.edu/ sites/default/files/journals/jrr/v015n01/p00012-p00018.pdf Аата обрашения: 12.12.2017.

Swenson J.E. Factors affecting status and reproduction of ospreys in Yellowstone National Park. - Journal Wildlife Management. 1979. 43: 595-601. DOI: 10.2307/3808736 URL: http://www.jstor.org/stable/3808736 Аата обрашения: 12.12.2017

Therres G.D., Byrd M.A., Bradshaw D.S. Effects of development on nesting baldeagles: case studies from Chesapeake Bay. - Transactions of the North American Wildlife and Natural Resources Conference. 1993. 58: 62-69. URL: https:// wildlife-management-institute.myshopify.com/products/ transactions-of-the-58th-north-american-wildlife-and-natural-resources-conference Аата обрашения: 12.12.2017.

Tjernberg $M$. Jaktmetoder, bytesval och jaktframgang hos overvintrande kungsornar i sodra Sverige. - Var Fagelvarld. 1986. 45 (6): 327-339 [Tjernberg M. Hunting behaviour, prey selection and strike success of wintering golden eagles in south Sweden. - Var Fagelvarld. 1986. 45 (6): 327-339].
Tornberg R., Colpaert A. Survival, ranging, habitat choice and diet of the Northern Goshawk Accipiter gentilis during winter in Northern Finland. - Ibis. 2001. 143: 41-50. DOI: 10.1111/j.1474-919X.2001.tb04168.x URL: http:// onlinelibrary.wiley.com/doi/10.1111/j.1474-919X.2001. tb04168.x/full Аата обрашения: 12.12.2017.

Tornberg R., Korpimäki E., Byholm P. Ecology of the northern goshawk in Fennoscandia. - Studies in Avian Biology. 2006. 31: 141-157. URL: http://www.avibirds.com/pdf/H/ Havik2.pdf Аата обрашения: 12.12.2017.

Toschik P.C., Christman M.C., Rattner B.A., Ottinger M.A. Evaluation of Osprey Habitat Suitability and Interaction with Contaminant Exposure. - The Journal of Wildlife Management. 2006. 70(4): 977-988. URL: http://www.jstor.org/stable/3803462 Аата обрашения: 12.12.2017.

Tucker G.M., Heath M.F. Birds in Europe: their conservation status. BirdLife International (Conservation Series No. 3). Cambridge, UK, 1994: 1-600.

U.S. Fish and Wildlife Service. National Bald Eagle Management Guidelines. 2007. URL: https://catalog.data.gov/ dataset/national-bald-eagle-management-guidelines $\triangle$ ата обрашения: 12.12.2017.

U.S. Forest Service. Sierra Nevada Forest Plan Amendment - Final Supplemental Environmental Impact Statement. U.S. Department of Agriculture, Forest Service, Pacific Southwest Region, Vallejo, California, 2004: 1-75. URL: https://www. fs.usda.gov/Internet/FSE_DOCUMENTS/stelprdb5434157. pdf Аата обрашения: 12.12.2017.

Vali $U$. The lesser spotted eagle and its conservation in Estonia. - Hirundo, Suppl. 6. 2003: 1-64. URL: https:// www.researchgate.net/publication/238621719_The_Lesser_Spotted_Eagle_and_its_conservation_in_Estonia $\triangle$ ата обрашения: 12.12.2017.

Van Daele L.J., Van Daele H.A. Factors affecting the productivity of ospreys nesting in west-central Idaho. - Condor. 1982. 84: 292-299. URL: https://sora.unm.edu/sites/default/files/journals/condor/v084n03/p0292-p0299.pdf $\triangle$ ата обрашения: 12.12.2017.

Van Horn R.C. Ferruginous Hawk and Prairie Falcon reproductive and behavioural responses to human activity near the Kevin Rim, Montana. Master of Science Thesis. Montana State University. 1993: 1-87. URL: http://scholarworks.montana. edu/xmlui/bitstream/handle/1/7246/31762102068390. pdf? sequence=1 Аата обрашения: 12.12.2017.

Village A. The kestrel. T \& AD Poyser, London, 1990: $1-352$.

Walker D., McGrady M., McCluskie A., Madders M., McLeod D.R.A. Resident Golden eagle ranging behaviour before and after construction of a windfarm in Argyll. - Scottish Birds. 2005. 25: 24-40. URL: https://www.researchgate. net/publication/281224614_Resident_Golden_Eagle_ranging_behaviour_before_and_after_construction_of_a_windfarm_in_Argyll Аата обрашения: 12.12.2017.

Wallgren $H$. Nest visibility - no trend over 27 years despite changed behaviour of the eagles. - Sea Eagle 2000. Proceedings from the International Conference at Bjökö, Sweden, 13-17 September 2000 / Eds. B. Helander, M. Marquiss, W. Bowerman. Stockholm: Swedish Society for Nature Conservation, 2003: 371-375.

Wallendorf M.J., Porneluzi P.A., Gram W.K., Clawson R.L., Faaborg J. Bird response to clear cutting in Missouri Ozark forests. - The Journal of Wildlife Management. 2007. 71: 1899-1905. DOI: 10.2193/2006-386 URL: http://onlinelibrary.wiley.com/doi/10.2193/2006-386/abstract Дата обрашения: 12.12 .2017$. 
Wallin D.O., Byrd M. A. Caledon State Park Bald Eagle Study. Virginia Department of Game and Inland Fisheries, Richmond, 1984: 1-53.

Watson J. Status of the Golden Eagle Aquila chrysaetos in Europe. - Bird Conservation International. 1992a. 2: 175-183. URL: https://www.cambridge.org/core/services/ aop-cambridge-core/content/view/F88B72ABB928AE5A7E753150AB34284B/S0959270900002422a.pdf $\triangle$ ата обрашения: 12.12 .2017 .

Watson J. Golden Eagle Aquila chrysaetos breeding success and afforestation in Argyll. - Bird Study. 1992b. 39: 203-206. URL: http://www.tandfonline.com/doi/ pdf/10.1080/00063659209477120 Аата обрашения: 12.12.2017.

Watson J.W. Responses of nesting Bald Eagles to experimental pedestrian activity. - Journal of Raptor Research. 2004. 38: 295-303. URL: https://sora.unm.edu/sites/default/files/journals/jrr/v038n04/p00295-p00303.pdf $\quad \Delta$ ата обрашения: 12.12.2017.

Watson J. The Golden Eagle. The Golden Eagle. Second Edition. Yale University Press, 2011: 1-400.

Watson J., Dennis R.H. Nest site selection by golden eagles Aquila chrysaetos in Scotland. - British Birds. 1992. 85: 469481. URL: https://britishbirds.co.uk/wp-content/uploads/ article_files/V85/V85_N09/V85_N09_P469_481_A133.pdf Аата обрашения: 12.12.2017.

Watson J.W., Pierce D.J. Bald eagle ecology in western Washington with an emphasis on the effects of human activity. Final Report. Washington Department of Fish and Wildlife, Olympia, Washington, USA. 1998.

Westall M.A. Osprey. - Audubon Wildlife Report 1986 / R.L. Di Silvestro Ed. New York: National Audubon Society, 1986: 889-909.

Weston M.A., McLeod E.M., Blumstein D.T., Guay P.-J. A review of flight-initiation distances and their application to managing disturbance to Australian birds. - Emu. 2012. 112: 269-286. DOI: 10.1071/MU12026 URL: https://blumsteinlab.eeb.ucla.edu/wp-content/uploads/ sites/104/2017/05/Weston_etal_2012_Emu.pdf Аата обрашения: 12.12 .2017$.

Wickl K.H. Der Uhu (Bubo bubo) in Bayern [The Eagle Owl (Bubo bubo) in Bavaria]. - Garmischer Vogelkundliche Berichte. 1979. 6: 1-47. URL: http://www.zobodat. at/pdf/Garmischer-Vogelkdl-Ber_6_0001-0047.pdf обрашения: 12.12.2017.

Widen $P$. The hunting habitats of goshawks Accipiter gentilis in boreal forests of central Sweden. - Ibis. 1989. 131: 205-231. DOI: 10.1111/j.1474-919X.1989.tb02763.x URL: http://onlinelibrary.wiley.com/doi/10.1111/j.1474919X.1989.tb02763.x/full Аата обрашения: 12.12.2017.

Widen $P$. How, and why, is the goshawk (Accipiter gentilis) affected by modern forest management in Fennoscandia. - Journal of Raptor Research. 1997. 31: 107-113. URL: https://sora.unm.edu/sites/default/files/journals/jrr/v031 n02/ p00107-p00113.pdf Аата обрашения: 12.12.2017.

Williams E.J. Conservation Assessment for Great Gray Owl (Strix nebulosa). USDA Forest Service Region 6 and USDI Bureau of Land Management, Oregon and Washington, 2012: 1-55. URL: https://www.fs.fed.us/r6/sfpnw/issssp/documents2/ca-bi-strix-nebulosa-2012-05.pdf Аата обрашения: 12.12.2017.

Williams D.R., Pople R.G., Showler D.A., Dicks L.V., Child M.F., zus Ermgassen E.K.H., Sutherland W.J. Bird Conservation: Global evidence for the effects of interventions. Exeter: Pelagic Publishing, 2013: 1-576.
Winter J. Status, distribution and ecology of the Great Gray Owl (Strix nebulosa) in California. Master of Science thesis, San Francisco State University, 1986: 1-121. URL: http://worldcat.org/oclc/16505339 Аата обрашения: 12.12.2017.

Wisdom M.J., Holthausen R.S., Wales B.C., Hargis C.D., Saab V.A., Lee D.C., Hann W.J., Rich T.D., Rowland M.M., Murphy W.J., Eames M.R. Source Habitats for Terrestrial Vertebrates of Focus in the Interior Columbia Basin: Broad-Scale Trends and Management Implications. 3 vol. Portland, Oregon: U.S. Department of Agriculture, Forest Service, Pacific Northwest Research Stations, 2000: 1-531. URL: https://www.fs.usda.gov/ treesearch/pubs/3081 Аата обрашения: 12.12.2017.

White C.M., Thurow T.L. Reproduction of ferruginous hawks exposed to controlled disturbance. - Condor. 1985. 87: 14-22. URL: https://sora.unm.edu/sites/default/files/journals/condor/v087n01/p0014-p0022.pdf Аата обрашения: 12.12.2017.

Whitfield D.P., McLeod D.R.A., Fielding A.H., Broad R.A., Evans R.J., Haworth P.F. The effects of forestry on Golden Eagles on the island of Mull, western Scotland. - Journal of Applied Ecology. 2001. 38: 1208-1220. URL: ftp://gisportal. mt.gov/Maxell/Models/Predictive_Modeling_for_DSS_Lincoln_NE_121510/Modeling_Literature/Whitfield_eaglehabaitat.pdf Аата обрашения: 12.12.2017.

Whitfield D.P., Ruddock M., Bullman R. Expert opinion as a tool for quantifying bird tolerance to human disturbance. Biological Conservation. 2008. 141(11): 2708-2717. DOI: 10.1016/j.biocon.2008.08.007 URL: https://www.sciencedirect.com/science/article/pii/S0006320708003005 Аата обрашения: 12.12.2017.

Wu J.X., Loffland H.L., Siegel R.B., Stermer C.A. Conservation Strategy for Great Gray Owls (Strix nebulosa) in California. Interim version 1.0. The Institute for Bird Populations and California Partners in Flight. Point Reyes Station, California, 2016: 1-88. URL: https://www.birdpop.org/docs/pubs/ IBPConservationStrategyVersion1.0.pdf Аата обрашения: 12.12.2017.

Yahner R.H. Responses of bird communities to early successional habitat in a managed landscape. - The Wilson Bulletin. 2003. 115: 292-298. DOI: 10.1676/03-018.URL: http:// www.bioone.org/doi/abs/10.1676/03-018 Аата обрашения: 12.12.2017.

Yosef R. Spring 1994 raptor and soaring bird migration at Eilat, Israel. - Journal of Raptor Research. 1995. 29(2): 127134. URL: https://sora.unm.edu/sites/default/files/journals/jrr/ v029n02/p00127-p00134.pdf Аата обрашения: 12.12.2017.

Youtz J.A., Graham R.T., Reynolds R.T., Simon J. Implementing Northern Goshawk Habitat Management in Southwestern Forests: A Template for Restoring Fire-Adapted Forest Ecosystems. - Integrated restoration of forested ecosystems to achieve multiresource benefits: proceedings of the 2007 national silviculture workshop. Gen. Tech. Rep. PNW-GTR-733 / R.L. Deal, tech. ed. Portland, OR: U.S. Department of Agriculture, Forest Service, Pacific Northwest Research Station, 2008: 173-1919. URL: https://www. fs.fed.us/pnw/publications/gtr733/PNW_GTR_733_6.pdf Аата обрашения: 12.12.2017.

Zuberogoitia I., Martínez J.E., Martínez J.A., Zabala J., Calvo J.F., Hidalgo S. Influence of management practices on nest site habitat selection, breeding and diet of the Common Buzzard Buteo buteo in two different areas of Spain. - Ardeola. 2004 53: 83-98. URL: http://www.globalraptors.org/grin/ researchers/uploads/521/management_practices_common_ buzzard_2006.pdf Аата обрашения: 12.12.2017. 